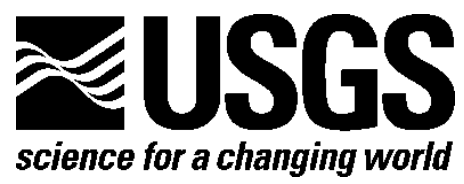

Prepared in cooperation with the U.S. Navy

\title{
Groundwater Withdrawals and Regional Flow Paths at and near Willow Grove and Warminster, Pennsylvania -Data Compilation and Preliminary Simulations for Conditions in 1999, 2010, 2013, 2016, and 2017
}

By Daniel J. Goode and Lisa A. Senior

Open-File Report 2019-1137

U.S. Department of the Interior

U.S. Geological Survey 


\title{
U.S. Department of the Interior DAVID BERNHARDT, Secretary
}

\author{
U.S. Geological Survey \\ James F. Reilly II, Director
}

U.S. Geological Survey, Reston, Virginia: 2020

For more information on the USGS—-the Federal source for science about the Earth, its natural and living resources, natural hazards, and the environment-visit https://www.usgs.gov/ or call 1-888-ASK-USGS (1-888-275-8747).

For an overview of USGS information products, including maps, imagery, and publications, visit https://store.usgs.gov/.

Any use of trade, firm, or product names is for descriptive purposes only and does not imply endorsement by the U.S. Government.

Although this information product, for the most part, is in the public domain, it also may contain copyrighted materials as noted in the text. Permission to reproduce copyrighted items must be secured from the copyright owner.

Suggested citation:

Goode, D.J., and Senior, L.A., 2020, Groundwater withdrawals and regional flow paths at and near Willow Grove and Warminster, Pennsylvania-Data compilation and preliminary simulations for conditions in 1999, 2010, 2013, 2016, and 2017: U.S. Geological Survey Open-File Report 2019-1137, 127 p., https://doi.org/10.3133/ofr20191137.

Associated data for this publication:

Goode, D.J., and Senior, L.A., 2020, MODFLOW 6 and MODPATH 7 model data sets used to evaluate groundwater flow in the vicinity of Horsham and Warminster, Bucks and Montgomery Counties, Pennsylvania-Preliminary simulations for conditions in 1999, 2010, 2013, 2016, and 2017: U.S. Geological Survey data release, https://doi.org/10.5066/P9K36P5S.

Senior, L.A., Ludlow, R.A., and Zarr, L.F, 2020, Groundwater levels, groundwater withdrawals, and point-source discharges to streams in the vicinity of Willow Grove and Warminster, Bucks and Montgomery Counties, Pennsylvania, for selected years during 1999-2017: U.S. Geological Survey data release, https://doi.org/10.5066/P9ZGEI67.

ISSN 2331-1258 (online) 


\section{Acknowledgments}

The support of U.S. Navy personnel and their contractors, Resolution Consultants, Tetra Tech Incorporated, and Battelle Memorial Institute is gratefully acknowledged. Data and other technical support, as well as permission to access wells from the Horsham Water and Sewer Authority and the Warminster Township Municipal Authority is gratefully acknowledged. Additionally, water-level data were provided by the Air National Guard and their contractor Leidos. William McLay, Montgomery County, Pennsylvania, and Robert H. Keough, Bucks County, Pennsylvania, provided stream geographic information system (GIS) data.

Numerous U.S. Geological Survey colleagues provided assistance to the project as follows: Michael Fienen and Christian Langevin for Python instructions and scripts for Pest++ calibration; Richard Winston for ModelMuse development and support; Linda Zarr and Russ Ludlow for database compilation; Matthew Conlon for data processing; Matthew Gyves and Scott Hoffman for GIS support; Dennis Risser for groundwater modeling and data analysis guidance; and Richard Yager and Paul Misut for colleague technical reviews. 


\section{Contents}

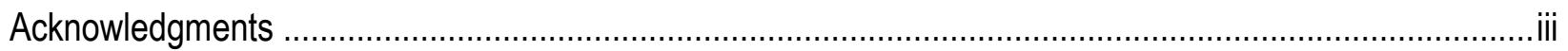

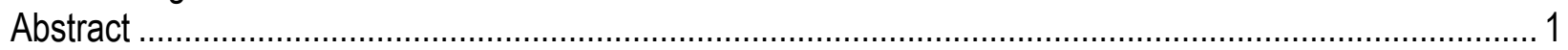

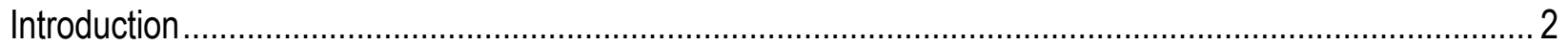

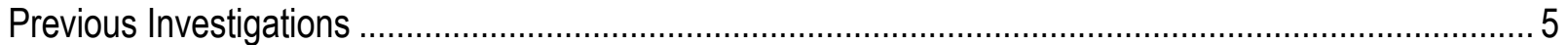

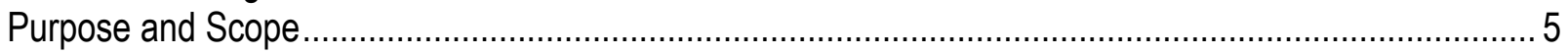

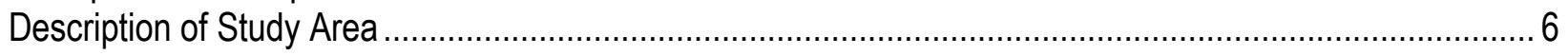

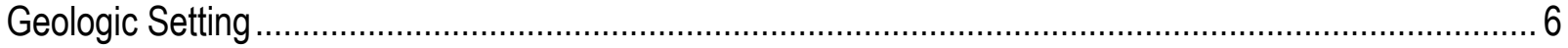

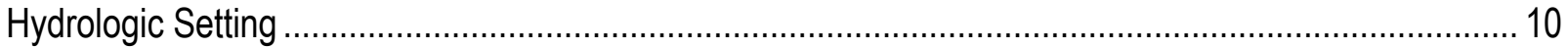

Hydrologic Conditions and Water Use, 1999-2017 …….............................................................. 11

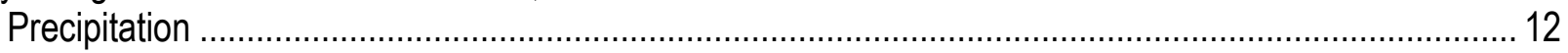

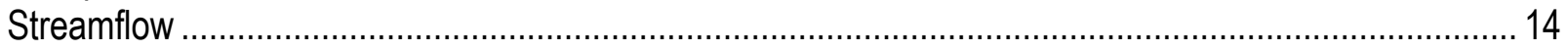

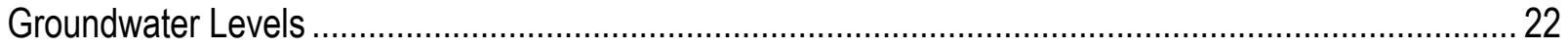

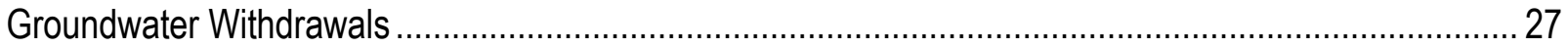

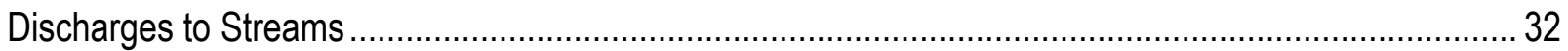

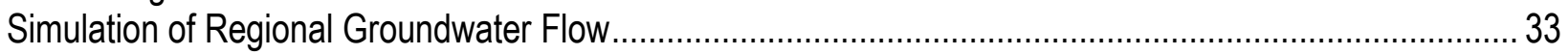

Conceptual Model of the Groundwater-Flow System ..................................................................... 33

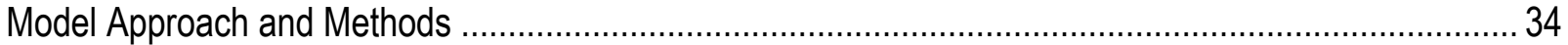

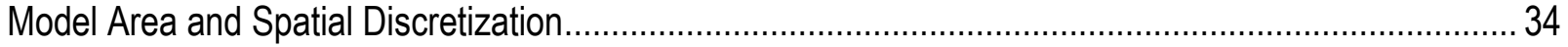

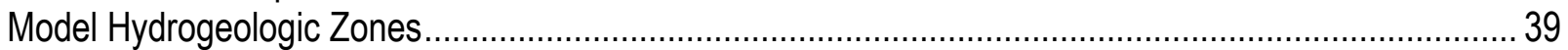

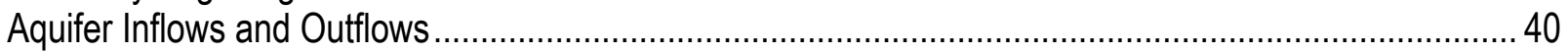

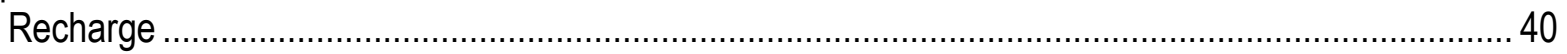

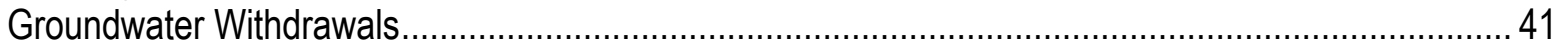

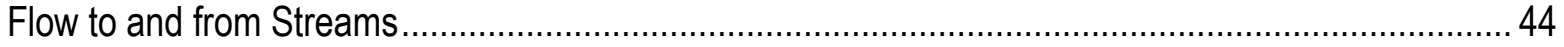

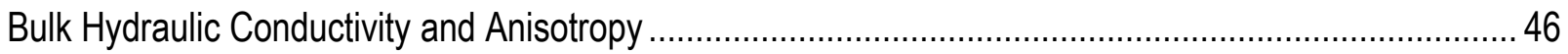

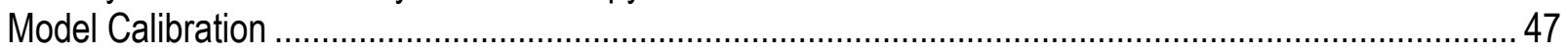

Effects of Recharge and Withdrawals on Groundwater-Flow Paths ................................................. 52

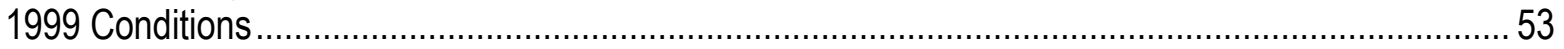

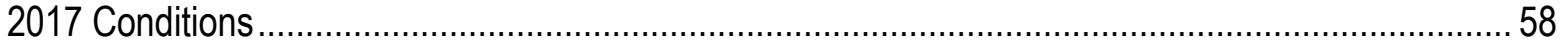

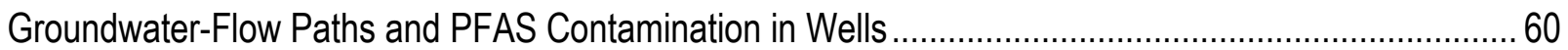

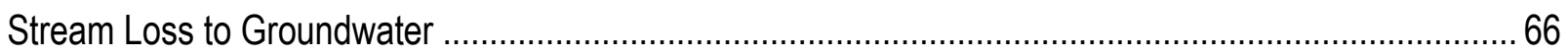

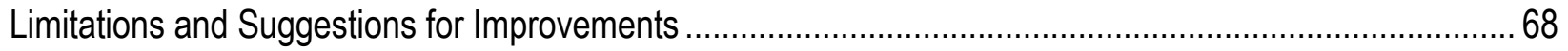

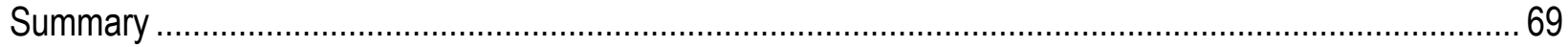

References Cited .............................................................................................................. 71

Appendix 1. Annual Base Flow as Determined from Measured Streamflow at Selected Gages and

Estimated for Missing Streamflow Records During 2010-2015 ..................................................... 79

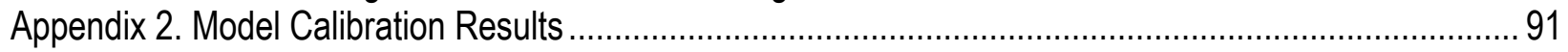

Appendix 3. Simulated Water Levels and Groundwater-Flow Paths...................................................... 101 


\section{Figures}

1. Locations of former Willow Grove Naval Air Station Joint Reserve Base, former Naval Air Warfare Center Warminster, and active Horsham Air Guard Station, land-surface altitudes, streams, and model grid boundary, Bucks and Montgomery Counties, Pennsylvania............... 3

2. Physiographic provinces of Pennsylvania and physiographic-province sections in the study area in southeastern Pennsylvania.

3. Geology of the study area and major faults, streams, selected U.S. Geological Survey stream gages and observation wells, and location of model grid, Bucks and Montgomery Counties, Pennsylvania.

4. Long-term daily mean depth to water in U.S. Geological Survey observation well BK-1020, completed in the Stockton Formation, Warminster Township, Bucks County, Pennsylvania...11

5. Mean annual total precipitation for Bucks and Montgomery Counties, Pennsylvania, 1990-2017.

6. Location of selected U.S. Geological Survey stream gages and long-term observation wells, wells with water levels used in model calibration, selected point-source discharges to streams above and near gages where data were used in model calibration, and model grid.

7. Data collected at Little Neshaminy Creek at Valley Road and Pennypack Creek gages, where base flow was determined using the HYSEP hydrograph separation method from the U.S. Geological Survey Groundwater Toolbox: $A$, Daily base flow and total streamflow, 1999-2018; $B$, Monthly base-flow and runoff components of streamflow, 2014-17; $C$, monthly base flow and sum of reported monthly discharges from sewage treatment plants above the gage, 2014-17; and D, base flow at Pennypack Creek at Horsham, Pennypack Creek tributary at Hatboro, and Pennypack Creek at Willow Grove with reported discharges from National Pollution Discharge Elimination System sources above Hatboro gage and Upper Moreland Hatboro STP above Willow Grove gage, 2010-16.

8. Groundwater levels in well BK-1020 and five Montgomery County network wells, as well as groundwater-level data used for model calibration in the time periods selected to represent calendar years A, 1999, and B, 2010, 2013, and 2016 conditions.

9. A, Distribution of well depths and $B$, relation between well depths and reported pumping rates for withdrawal wells in 1999 and 2010 in the model area near Willow Grove and Warminster, Pennsylvania.

10. Total annual average reported well and quarry withdrawals in the model area near Willow Grove and Warminster, Pennsylvania, in 1995, 1999, 2010, 2013, 2014, 2016, and 2017...... 30

11. ModelMuse screenshot of full model grid with model streams near Willow Grove and Warminster, Pennsylvania.

12. ModelMuse screenshot of detail of model grid cells and withdrawal well locations close to the bases near Willow Grove and Warminster, Pennsylvania.

13. ModelMuse screenshot of details near Willow Grove of model grid in plan and cross section showing seven model layers with illustrative regional groundwater-flow paths from possible sources to discharge cells.

14. ModelMuse screenshot of model hydrogeologic zones: Upper Stockton, Middle and Lower Stockton, Lockatong, Brunswick, Carbonate, and Other. 
15. ModelMuse screenshot of model recharge rates in 2010 and 2013 in inches per year, zoned by geologic unit. Recharge rates for other periods were reduced to 90 percent of the values shown for 1999 and 70 percent for 2016 and 2017.

16. ModelMuse screenshot of model groundwater withdrawal rates visualized as well-withdrawal footprints for simulation of conditions in 1999.

17. ModelMuse screenshot of model groundwater withdrawal rates visualized as well-withdrawal footprints for simulation of conditions in 2017.

18. ModelMuse screenshot of changes in groundwater withdrawal rates in the Willow Grove and Warminster area visualized by the difference between well-withdrawal footprints for 1999 and 2017.

19. ModelMuse screenshot of locations of model point discharges to streams.

20. ModelMuse screenshot showing model down dip angles to the northwest for hydraulic conductivity tensor in model layers 3 to 7 , which represent unweathered fractured rock

21. Simulated and measured water levels in wells for optimum parameters identified by calibration

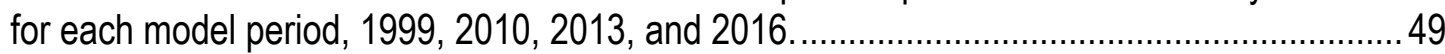

22. Histogram of water-level residuals for all calibration data for all model periods. .....................50

23. Simulated and measured streamflow for optimum parameters identified by calibration for all model periods

24. ModelMuse screenshot of simulated potentiometric surface in model layer 1 for 1999 conditions.

25. ModelMuse screenshot of simulated areas that contribute recharge to discharging wells and streams for 1999 conditions.

26. ModelMuse screenshot of simulated regional groundwater-flow paths from locations of possible per- and polyfluoroalkyl substances contamination in groundwater for 1999 conditions

27. Detail of ModelMuse screenshot of simulated regional groundwater-flow paths for 1999 conditions near Willow Grove

28. Detail of ModelMuse screenshot of simulated regional groundwater-flow paths for 1999 conditions near Warminster.

29. Detail of ModelMuse screenshot of simulated regional groundwater-flow paths for 2017 conditions near Willow Grove.

30. Detail of ModelMuse screenshot of simulated regional groundwater-flow paths for 2017 conditions near Warminster.

31. Private-well sampling areas and levels of perfluorooctane sulfonate and perfluorooctanoic acid in well-water samples relative to drinking-water health advisories for Horsham Air Guard Station and the former Naval Air Station Joint Reserve Base Willow Grove as of September, 2019.

32. Private-well sampling areas and levels of perfluorooctane sulfonate and perfluorooctanoic acid in well-water samples relative to drinking-water health advisories for the former Naval Air Warfare Center Warminster as of January, 2019.

33. Composite simulated regional groundwater-flow paths from possible per- and polyfluoroalkyl substances contamination sources at Willow Grove and Warminster for conditions in 1999, 2010, 2013, 2016, and 2017 and maximum levels of perfluorooctane 
sulfonate and perfluorooctanoic acid in 2014-2018 well-water samples relative to drinkingwater health advisories.

34. Detail at Willow Grove of composite simulated regional groundwater-flow paths from possible per- and polyfluoroalkyl substances contamination sources for conditions in 1999, 2010, 2013, 2016, and 2017 and maximum levels of perfluorooctane sulfonate and perfluorooctanoic acid in 2014-2018 well-water samples relative to drinking-water health advisories.

35. Detail at Warminster of composite simulated regional groundwater-flow paths from possible per- and polyfluoroalkyl substances contamination sources for conditions in 1999, 2010, 2013, 2016, and 2017 and maximum levels of perfluorooctane sulfonate and perfluorooctanoic acid in 2014-2018 well-water samples relative to drinking-water health advisories.

36. Detail near Willow Grove, Park Creek, and Little Neshaminy Creek of ModelMuse screenshot of simulated potentiometric surface in model layer 1 , regional flow paths from possible per- and polyfluoroalkyl substances contamination in groundwater, and locations of stream loss for conditions in 1999 . 66

37. ModelMuse screenshot detail near Willow Grove, Park Creek, and Little Neshaminy Creek of the simulated potentiometric surface in model layer 1 , regional flow paths from possible perand polyfluoroalkyl substances contamination in groundwater, and locations of stream loss for conditions in 2017. 


\section{Tables}

1. Annual total county-wide precipitation for Bucks and Montgomery Counties, Pennsylvania, 1990-2017. .

2. Period of record and type of data recorded for selected U.S. Geological Survey stream gages and observation wells in the study area in and near Willow Grove and Warminster, Pennsylvania, 1990-2017.

3. Annual average base flow at selected stream gages near Willow Grove and Warminster, Pennsylvania, 1999 and 2010-2017.

4. Summary statistics for wells with water levels used in model calibration scenarios for 1999, 2010, 2013, and 2016 conditions, including land-surface altitude, depth to top and bottom of well opening, date of water-level measurement, and depth to water near Willow Grove and Warminster, Pennsylvania.

5. Summary statistics for pumping wells with withdrawals used in model scenarios for 1999, 2010, 2013, 2016 and 2017 conditions, including land-surface altitude and depth to top and bottom of well opening, near Willow Grove and Warminster, Pennsylvania. 29

6. Annual average withdrawals for wells and quarries in model area for selected years, 1995-2017, near Willow Grove and Warminster, Pennsylvania.

7. Annual average discharge rates for point source discharges to streams in model area for model scenarios for 1999, 2010, 2013, 2016, and 2017 conditions near Willow Grove and Warminster, Pennsylvania.

8. Model layer thicknesses and hydraulic conductivity variation with depth.................................... 38

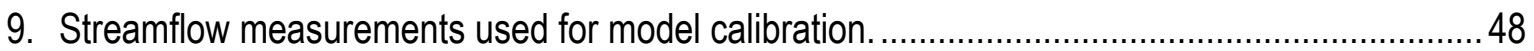

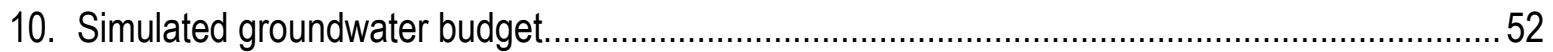




\section{Conversion Factors}

U.S. customary units to International System of Units

\begin{tabular}{|c|c|c|}
\hline Multiply & By & To obtain \\
\hline \multicolumn{3}{|c|}{ Length } \\
\hline inch (in.) & 25.4 & millimeter $(\mathrm{mm})$ \\
\hline foot $(\mathrm{ft})$ & 0.3048 & meter $(\mathrm{m})$ \\
\hline mile (mi) & 1.609 & kilometer $(\mathrm{km})$ \\
\hline \multicolumn{3}{|c|}{ Area } \\
\hline square foot $\left(\mathrm{ft}^{2}\right)$ & 0.09290 & square meter $\left(\mathrm{m}^{2}\right)$ \\
\hline square mile $\left(\mathrm{mi}^{2}\right)$ & 2.590 & square kilometer $\left(\mathrm{km}^{2}\right)$ \\
\hline \multicolumn{3}{|c|}{ Volume } \\
\hline gallon (gal) & 3.785 & liter (L) \\
\hline gallon (gal) & 0.003785 & cubic meter $\left(\mathrm{m}^{3}\right)$ \\
\hline million gallons (Mgal) & 3,785 & cubic meter $\left(\mathrm{m}^{3}\right)$ \\
\hline cubic foot $\left(\mathrm{ft}^{3}\right)$ & 0.02832 & cubic meter $\left(\mathrm{m}^{3}\right)$ \\
\hline \multicolumn{3}{|c|}{ Flow rate } \\
\hline cubic foot per second $\left(\mathrm{ft}^{3} / \mathrm{s}\right)$ & 0.02832 & cubic meter per second $\left(\mathrm{m}^{3} / \mathrm{s}\right)$ \\
\hline gallon per minute (gal/min) & 0.06309 & liter per second $(\mathrm{L} / \mathrm{s})$ \\
\hline million gallons per day (Mgal/d) & 0.04381 & cubic meter per second $\left(\mathrm{m}^{3} / \mathrm{s}\right)$ \\
\hline inch per year (in/yr) & 25.4 & millimeter per year $(\mathrm{mm} / \mathrm{yr})$ \\
\hline \multicolumn{3}{|c|}{ Hydraulic conductivity } \\
\hline foot per day $(\mathrm{ft} / \mathrm{d})$ & 0.3048 & meter per day $(\mathrm{m} / \mathrm{d})$ \\
\hline
\end{tabular}

International System of Units to U.S. customary units

\begin{tabular}{|c|c|c|}
\hline Multiply & By & To obtain \\
\hline \multicolumn{3}{|c|}{ Length } \\
\hline millimeter $(\mathrm{mm})$ & 0.03937 & inch (in.) \\
\hline meter $(\mathrm{m})$ & 3.281 & foot (ft) \\
\hline kilometer $(\mathrm{km})$ & 0.6214 & mile (mi) \\
\hline \multicolumn{3}{|c|}{ Area } \\
\hline square meter $\left(\mathrm{m}^{2}\right)$ & 10.76 & square foot $\left(\mathrm{ft}^{2}\right)$ \\
\hline square kilometer $\left(\mathrm{km}^{2}\right)$ & 0.3861 & square mile $\left(\mathrm{mi}^{2}\right)$ \\
\hline \multicolumn{3}{|c|}{ Volume } \\
\hline liter $(\mathrm{L})$ & 0.2642 & gallon (gal) \\
\hline cubic meter $\left(\mathrm{m}^{3}\right)$ & 264.2 & gallon (gal) \\
\hline liter (L) & 61.02 & cubic inch $\left(\mathrm{in}^{3}\right)$ \\
\hline cubic meter $\left(\mathrm{m}^{3}\right)$ & 35.31 & cubic foot $\left(\mathrm{ft}^{3}\right)$ \\
\hline \multicolumn{3}{|c|}{ Flow rate } \\
\hline meter per second $(\mathrm{m} / \mathrm{s})$ & 3.281 & foot per second (ft/s) \\
\hline cubic meter per second $\left(\mathrm{m}^{3} / \mathrm{s}\right)$ & 35.31 & cubic foot per second $\left(\mathrm{ft}^{3} / \mathrm{s}\right)$ \\
\hline cubic meter per day $\left(\mathrm{m}^{3} / \mathrm{d}\right)$ & 35.31 & cubic foot per day $\left(\mathrm{ft}^{3} / \mathrm{d}\right)$ \\
\hline cubic meter per day $\left(\mathrm{m}^{3} / \mathrm{d}\right)$ & 264.2 & gallon per day (gal/d) \\
\hline \multicolumn{3}{|c|}{ Hydraulic conductivity } \\
\hline meter per day $(\mathrm{m} / \mathrm{d})$ & 3.281 & foot per day $(\mathrm{ft} / \mathrm{d})$ \\
\hline
\end{tabular}

Temperature in degrees Celsius $\left({ }^{\circ} \mathrm{C}\right)$ may be converted to degrees Fahrenheit $\left({ }^{\circ} \mathrm{F}\right)$ as ${ }^{\circ} \mathrm{F}=\left(1.8 \times{ }^{\circ} \mathrm{C}\right)+32$. Temperature in degrees Fahrenheit $\left({ }^{\circ} \mathrm{F}\right)$ may be converted to degrees Celsius $\left({ }^{\circ} \mathrm{C}\right)$ as ${ }^{\circ} \mathrm{C}=\left({ }^{\circ} \mathrm{F}-32\right) / 1.8$. 


\section{Datum}

Vertical coordinate information is referenced to the North American Vertical Datum of 1988 (NAVD 88). Horizontal coordinate information is referenced to the North American Datum of 1983 (NAD 83). Altitude, as used in this report, refers to distance above the vertical datum.

\section{Abbreviations}

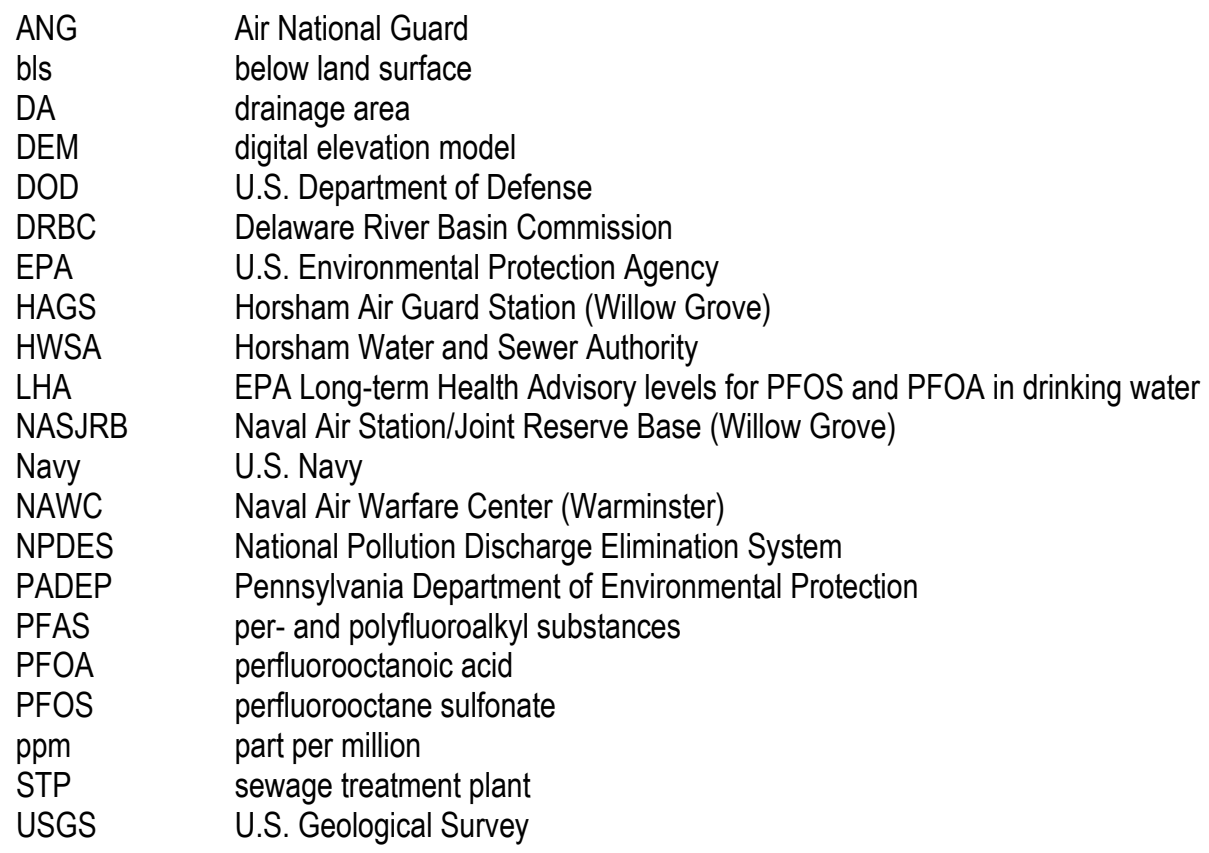




\title{
Groundwater Withdrawals and Regional Flow Paths at and near Willow Grove and Warminster, Pennsylvania -Data Compilation and Preliminary Simulations for Conditions in 1999, 2010, 2013, 2016, and 2017
}

\author{
By Daniel J. Goode and Lisa A. Senior
}

\begin{abstract}
In 2014, groundwater samples from residential and public supply wells in the vicinity of two former U.S. Navy bases at Willow Grove and Warminster, and an active Air National Guard Station at Horsham, Bucks and Montgomery Counties, Pennsylvania, were found to have concentrations of perfluorooctanoic acid (PFOA) and perfluorooctane sulfonate (PFOS), which are per- and polyfluoroalkyl substances (PFAS), above U.S. Environmental Protection Agency (EPA) provisional health advisory (HA) levels for drinking water. Five supply wells near the bases were shut down because of PFAS contamination. In 2016, after EPA established a Lifetime HA for PFAS in drinking water that is lower than the provisional HA in place in 2014, at least 13 additional supply wells near the bases were shut down because of PFAS contamination. At the request of the U.S. Navy, and in consultation with other Federal and State agencies and local stakeholders, the U.S. Geological Survey used historical and recent data on well withdrawals, recharge rates, aquifer properties, groundwater levels, and stream base flow to evaluate regional groundwater-flow paths from identified areas of PFAS groundwater contamination or potential PFAS sources at the bases. Groundwater withdrawals near the bases from public supply and other large wells decreased substantially from the 1990s to 2017, increasing the proportion of groundwater recharge that discharged to local streams. A preliminary groundwater-flow model, calibrated using 1,009 groundwater levels and 17 stream base flow estimates, simulated regional flow paths from the bases and showed that recharge at the bases discharged to withdrawal wells and local streams, generally within a mile or two of the bases. Supply and remediation wells at the bases captured some of the recharge on base areas of possible PFAS contamination, whereas other base recharge was simulated to flow to nearby public supply wells and streams, depending on water use and aquifer recharge conditions between 1999 and 2017. The locations of many residential wells near the bases that were identified by the Navy and Air National Guard as having elevated PFAS concentrations were generally consistent with the simulated flow paths from possible sources at the bases. However, there are some areas of observed PFAS contamination where no flow paths from base sources were simulated. Additionally, no data were available on PFAS concentrations in groundwater in some areas of simulated flow paths from base sources. Data and models used for this study are provided in this report and in digital data releases to support further investigations and model revisions.
\end{abstract}




\section{Introduction}

Groundwater is a substantial source of public, domestic, and industrial water supply in areas underlain by the Stockton Formation, a fractured sandstone aquifer, in southern Montgomery and Bucks Counties, Pennsylvania, where two formerly active military bases are located. Both bases were active for at least 50 years from the 1940s until they were closed at the recommendation of the Base Realignment and Closure (BRAC) commission. The Willow Grove Naval Air Station Joint Reserve Base (NASJRB) in Horsham Township, Montgomery County, Pennsylvania, was operated by the U.S. Navy (Navy) from 1942 until September 2011, with a portion currently (2019) operated by the Pennsylvania Air National Guard (ANG) and designated Horsham Air Guard Station (HAGS) (fig. 1). At present (2019), the entire Willow Grove NASJRB base property remains within the control of the Navy or the ANG, with the exception of a 3-acre parcel transferred to the Federal Aviation Administration. The Naval Air Warfare Center (NAWC) Warminster (formerly the Naval Air Development Center, Johnsville) in Warminster and Northampton Townships, Bucks County (fig. 1) was active during 1944-96. Since 1996, all but about 5 acres of the former NAWC Warminster property has been transferred from the Navy to local municipalities, Bucks County, or private owners.

Previous investigations identified areas of groundwater contaminated by volatile organic compounds at both Willow Grove NASJRB and NAWC Warminster, which subsequently were addressed by remediation. Ongoing remediation at present (2019) includes bioremediation at Willow Grove NASJRB (Naval Facilities Engineering Command, 2018) and pump and treat technology at NAWC Warminster (Battelle Memorial Institute, 2016).

In summer 2014, through sampling of public supply wells under the third Unregulated Contaminant Monitoring Rule (UCMR3) (U.S. Environmental Protection Agency, 2012) groundwater at and near the former Willow Grove NASJRB and former NAWC Warminster was found to be contaminated with perfluorooctane sulfonate (PFOS) and perfluorooctanoic acid (PFOA), compounds that may pose a risk to human health if present above certain concentrations in drinking water. In 2014, the U.S. Environmental Protection Agency (EPA) provisional health advisory (PHA) levels were 0.2 microgram per liter $(\mu \mathrm{g} / \mathrm{L})$ for PFOS and $0.4 \mu \mathrm{g} / \mathrm{L}$ for PFOA in drinking water (U.S. Environmental Protection Agency, 2014). PFOS and PFOA are part of a group of compounds more broadly designated as per- and polyfluoroalkyl substances (PFAS). Five public supply wells in Horsham and Warrington Townships were shut down in 2014 after UCMR3 sampling showed that produced water had PFAS concentrations that exceeded the PHA levels. 


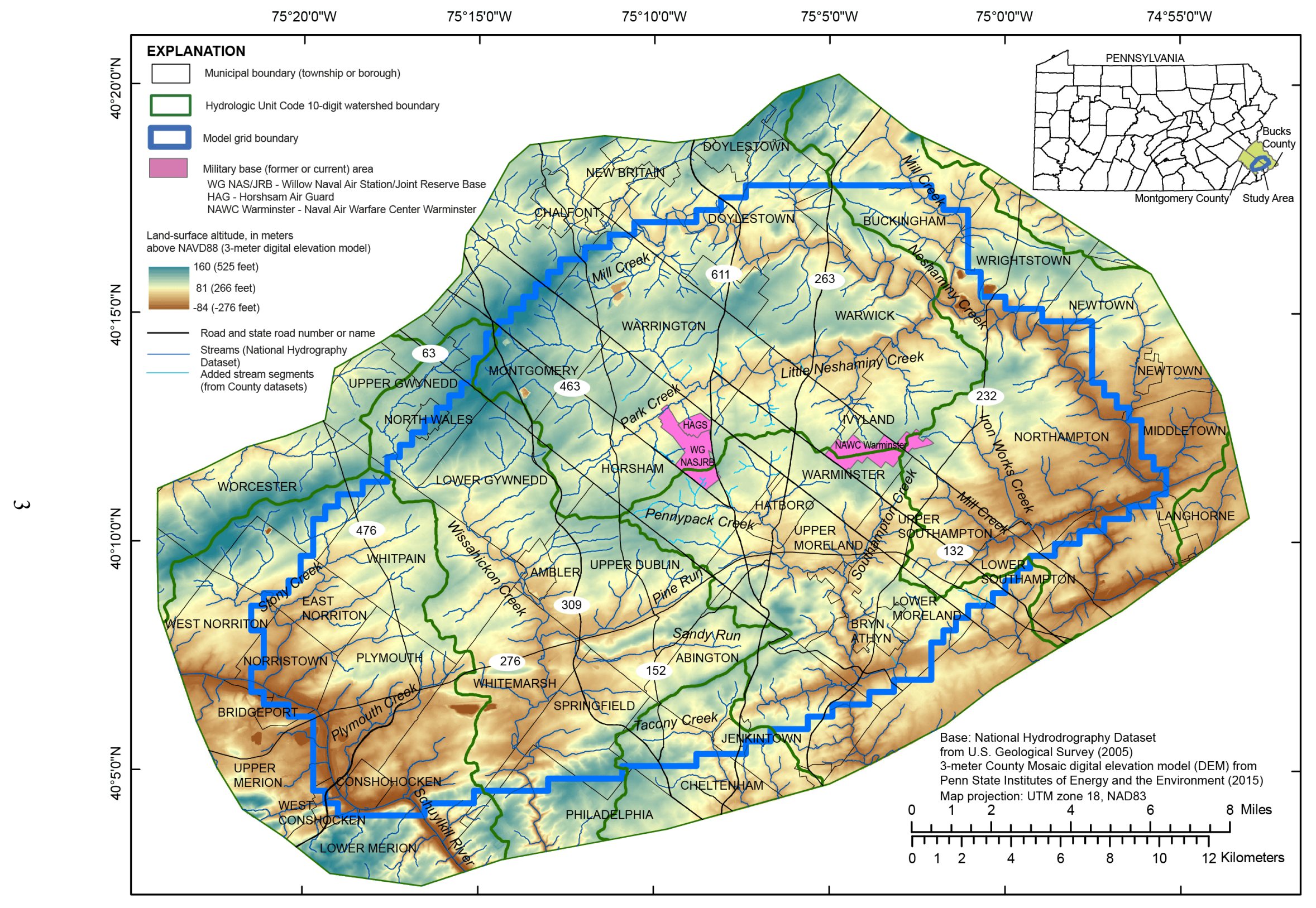

Figure 1. Location of former Willow Grove Naval Air Station Joint Reserve Base (NASJRB), former Naval Air Warfare Center Warminster (NAWC), and active Horsham Air Guard Station (HAGS), land-surface altitudes, streams, and model grid boundary, Bucks and Montgomery Counties, Pennsylvania. 
When PFOS and PFOA were identified in samples from public supply wells in 2014, production wells on and near the Willow Grove NASJRB and former NAWC Warminster were the primary sources of public water supply for communities within and surrounding these facilities and private domestic wells supplied many nearby residences. Potential sources of PFOS and PFOA in the area include fire-suppressant compounds (fluorinated surfactants in aqueous film forming foams) used on and (or) near these facilities when the bases were operating. Some public supply wells have been shut down since summer 2014 because PFOS and PFOA concentrations in produced water were higher than the PHA levels of $0.2 \mu \mathrm{g} / \mathrm{L}$ for PFOS and $0.4 \mu \mathrm{g} / \mathrm{L}$ for PFOA in drinking water (U.S. Environmental Protection Agency, 2014). In May 2016, the EPA revised the PFOS and PFOA health advisories to lower concentration levels and established a Lifetime Health Advisory (LHA) not to exceed 70 nanograms per liter (ng/L) or 70 parts per trillion (ppt) (equivalent to $0.07 \mu \mathrm{g} / \mathrm{L}$ ) for combined concentrations of PFOS and PFOA (U.S. Environmental Protection Agency, 2016). Groundwater from public supply or private wells was still a primary source of drinking water in the area in 2014, but after May 2016, additional (at least 13) public supply wells were shut down in Horsham, Warrington, and Warminster Townships because of health concerns related to the presence of PFOS and PFOA. Since 2016, some supply wells have remained active, or resumed active status, with treatment that was subsequently installed to remove PFOS and PFOA from pumped groundwater, as needed.

After PFAS was discovered in the area, the Navy and the ANG offered nearby residences with private domestic wells that yielded water with PFOS and PFOA concentrations greater than the LHA to be connected to public drinking water supplies. The Navy and ANG also have established a program to monitor PFOS and PFOA concentrations in water from nearby residential wells that have not been connected to public supply; these monitored wells include those for which combined PFOS plus PFOA concentrations were less than the LHA of $0.07 \mu \mathrm{g} / \mathrm{L}$ but higher than $0.04 \mu \mathrm{g} / \mathrm{L}$.

Management and mitigation of groundwater that is contaminated with PFOS and PFOA on and near the Willow Grove NASJRB and the nearby former NAWC Warminster requires understanding of groundwater flow directions under various pumping scenarios. A regional understanding of groundwater flow is needed as a result of extensive pumping near and between the two facilities, located about 3 miles (mi) apart (fig. 1). Because of the complex aquifer heterogeneity, the distribution and complex pattern of pumping wells, variability of recharge, and groundwater-surface water exchanges in the area, a tool such as numerical groundwater modeling is essential to interpret site monitoring data, and to understand and describe groundwater flow directions and associated contaminant transport under various scenarios. Such a tool also would be useful to inform selection of additional monitoring locations and could be updated as new monitoring data become available.

Flowing groundwater can carry contaminants from source areas near the land surface to downgradient discharges at streams or wells by advection, by which dissolved contaminants such as PFAS are carried with the water. However, additional processes can affect transport of contaminants to varying extents, and these additional processes are not addressed by flow modeling alone. Diffusion is small-scale molecular spreading from areas of high concentration to areas of low concentration. Some contaminants will additionally adsorb to aquifer materials, which causes an apparent delay, or retardation, of the rate of contaminant migration relative to the groundwater. 
Contaminant transport in fractured-rock aquifers is further affected by the variability of the properties of fractured and unfractured strata. Transport occurs primarily in open fractures or fracture zones, and the variability of the apertures of fractures causes variability in local velocities that results in dispersion, or the separation of contaminants on flow paths having different velocities. Further, contaminants can diffuse from fast flowing fractures into immobile or nearly immobile water within the matrix of pores in unfractured rock. This matrix diffusion can further retard the rate of transport of contaminants relative to the groundwater in the fractures.

\section{Previous Investigations}

In studies related to remedial investigations by the Navy and their contractors at the two former Willow Grove and Warminster bases, the U.S. Geological Survey (USGS) collected geophysical logs (Conger 1997, 1998, 1999; Conger and Bird, 1999; Sloto, 2008) conducted aquifer-interval isolation (packer) testing of wells (Sloto, 1997, 1998, 2007; Sloto and others, 2002) and hydrologic investigations (Sloto and others, 1998; Sloto, 2002), and prepared watertable maps at or near the bases (Sloto and others, 2001; Sloto and Grazul, 1995). Sloto and others (1996) and Sloto (2010) investigated groundwater flow and volatile organic compound contaminant migration at a Superfund site near NAWC Warminster. The USGS also conducted township-wide hydrogeologic studies for Warminster Township (Sloto and Davis, 1982) and Warwick Township (Bird, 1998) and prepared a water-table map for Warwick Township (Rowland, 1997). Sloto and others (1996) described the hydrology of the Stockton Formation in Hatboro and Warminster Township. The hydrogeology of northern Bucks County east of Neshaminy Creek, which includes an area of diabase, was described by Sloto and Schreffler (1994).

Additional investigations have been conducted by local water suppliers, by regulatory agencies, and by parties responsible for contamination of groundwater in the area. Many of these investigations are described in documents available in public record depositories. Specific investigations that provided data for this study are cited throughout this report.

\section{Purpose and Scope}

This report documents hydrologic data compiled to support development and calibration of a numerical model to simulate regional groundwater flow under selected conditions during 1999-2017 at and near the former Willow Grove NASJRB and NAWC Warminster in Montgomery and Bucks Counties, Pennsylvania. The hydrologic data include water levels in wells, streamflow, point discharges to streams, groundwater withdrawals (pumping wells and quarries), and precipitation. The report also describes model development, calibration, and simulations. The model simulations provide information on regional groundwater-flow paths and groundwater/surface-water exchanges, in relation to changes in water supply pumping and recharge rates. Groundwater-flow paths from possible PFAS sources at the former bases are simulated under steady-state conditions for the years 1999, 2010, 2013, 2016, and 2017. Limitations of the study findings and modeling are also discussed. 


\section{Description of Study Area}

The study area lies within Bucks and Montgomery Counties in southeastern Pennsylvania, where land use is mixed. A small part of the study area is in Philadelphia County. The largest land uses in the study area in 2010 were residential (about 36 percent), wooded/open/ vacant (about 26 percent), industrial/commercial/institutional/transportation (about 24 percent), and agricultural (about 12 percent) (Delaware Valley Regional Planning Commission, 2013; 2019). The study area has been settled since the 18th century and has become increasingly more populated and urbanized since the 1960s. The former Willow Grove NASJRB is in Horsham Township, Montgomery County, and the former NAWC Warminster is in Warminster and Northampton Townships, Bucks County (fig. 1). Other municipalities adjacent to, or near (within 2 mi of), the former bases include Warrington, Warwick, and Upper Southampton Townships, and Ivyland Borough in Bucks County, and Upper Moreland Township and Hatboro Borough in Montgomery County (fig. 1). Reported 2010 populations for these municipalities are 26,147 in Horsham Township, 32,682 in Warminster Township, 39,726 in Northampton Township, 23,418 in Warrington Township, 14,437 in Warwick Township, 15,152 in Upper Southampton Township, 1,041 in Ivyland Borough, 24,015 in Upper Moreland Township and 7,360 in Hatboro Borough (U.S. Census Bureau, 2019).

\section{Geologic Setting}

The study area lies within the Piedmont physiographic province, with most of the study area in the Gettysburg-Newark Lowlands Section (fig. 2) characterized by rolling topography and shallow valleys (Sevon, 2000). The southern portion of the study area is located in the Piedmont Upland and Lowland Sections. The Gettysburg-Newark Lowlands are underlain by sedimentary rocks of the Newark Basin, which were deposited in a rift basin during the Triassic (about 250 million years ago) and subsequently buried, compacted, and faulted, and in places, intruded by diabase (Lyttle and Epstein, 1987). Sedimentary formations in the Newark Basin, in order of decreasing age, are the Stockton Formation, Lockatong Formation, and Brunswick Group. The Piedmont Upland and Lowland Sections are underlain by Paleozoic metasedimentary rocks and older (Proterozoic) metamorphic rocks.

The central part of the study area is underlain by the Triassic Stockton Formation (fig. 3), which consists of gray to reddish brown sandstones and conglomerates, with siltstone and shale. The Stockton Formation was deposited unconformably on folded and faulted metamorphic rocks of Paleozoic- and Proterozoic-age, which crop out along the southern border of the Stockton Formation and include carbonates, quartzites, schists, and gneisses (fig. 3). The Stockton Formation has been divided into three members in Montgomery County, which are present in a generally fining upward sequence: the lower member is composed of conglomerates and sandstones; the middle member is composed of fine- to medium-grained sandstones; and the upper member is composed of shales, siltstones, and fine-grained sandstones (Rima and others, 1962). Locally, lithologies may interfinger in the Stockton Formation and beds may pinch out (Rima and others, 1962) or be laterally discontinuous, likely a result of the fluvial or deltaic origin of some deposits within the Stockton Formation (Turner-Peterson and Smoot, 1985). 


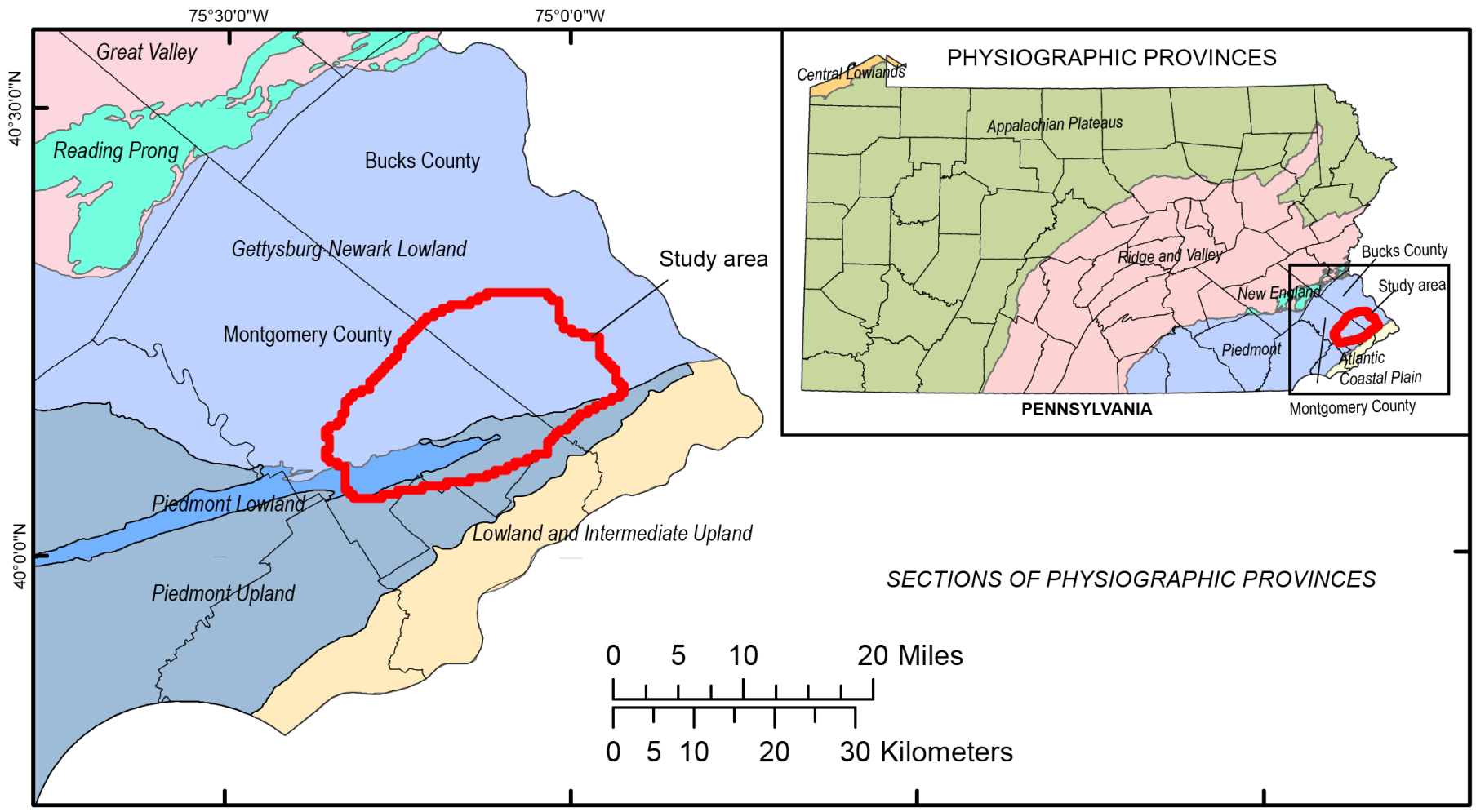

Figure 2. Physiographic provinces of Pennsylvania and physiographic-province sections in the study area in southeastern Pennsylvania.

The Lockatong Formation, which overlies and is conformable with the Stockton Formation, consists of fine-grained lacustrine deposits (siltstones and shales) and is relatively resistant to erosion, forming ridges that rise above flat or rolling topography underlain by the Stockton Formation to the south and rocks of the overlying Brunswick Group (shales, siltstones, and fine-grained sandstones) to the north (fig. 3).

Bedding within the Stockton Formation in southeastern Montgomery and Bucks Counties generally strikes northeast or east-northeast and dips about 5 to 18 degrees to the northwest or north-northwest in this region, with an average dip of about 12 degrees (Rima and others, 1962). Although bedding in the Stockton Formation may be laterally discontinuous in places owing to interbedding of lithologies, the beds have been mapped as oriented with the overall general northwest-dipping structure (Rima and others, 1962). In addition to the Stockton Formation, the other Triassic sedimentary rocks in the study area also generally strike northeast and dip northwest, except where interrupted by faulting (Schlische, 1992). Both major and minor faults are present in the area. A major regional fault, the Chalfont Fault, is about $3 \mathrm{mi}$ (5 kilometers $[\mathrm{km}]$ ) north of Willow Grove NASJRB (fig. 3), and a zone of intense normal faulting south of the Chalfont Fault has been mapped about $1 \mathrm{mi}(1.5 \mathrm{~km})$ west of the Willow Grove NASJRB (Schlische, 1992). A north-south trending, steeply dipping diabase dike is mapped as intruding the Stockton Formation on the east border of the former Willow Grove NASJRB (Rima and others, 1962; Lyttle and Epstein, 1987). Other smaller dikes may be present, as indicated in mapping by Lyttle and Epstein (1987) that shows a minor dike about $1 \mathrm{mi}$ or less west of the north-south trending dike on the eastern border of Willow NASJRB.

The depth to competent bedrock generally is about 40 feet $(\mathrm{ft})$ or less but varies depending on lithology and topographic setting (Low and others, 2002). The competent bedrock is overlain by weathered bedrock (saprolite) and soil formed in-situ and, in a few places in the southern part of the study area, by thin deposits of Tertiary and Cretaceous unconsolidated sediments (fig. 3). 


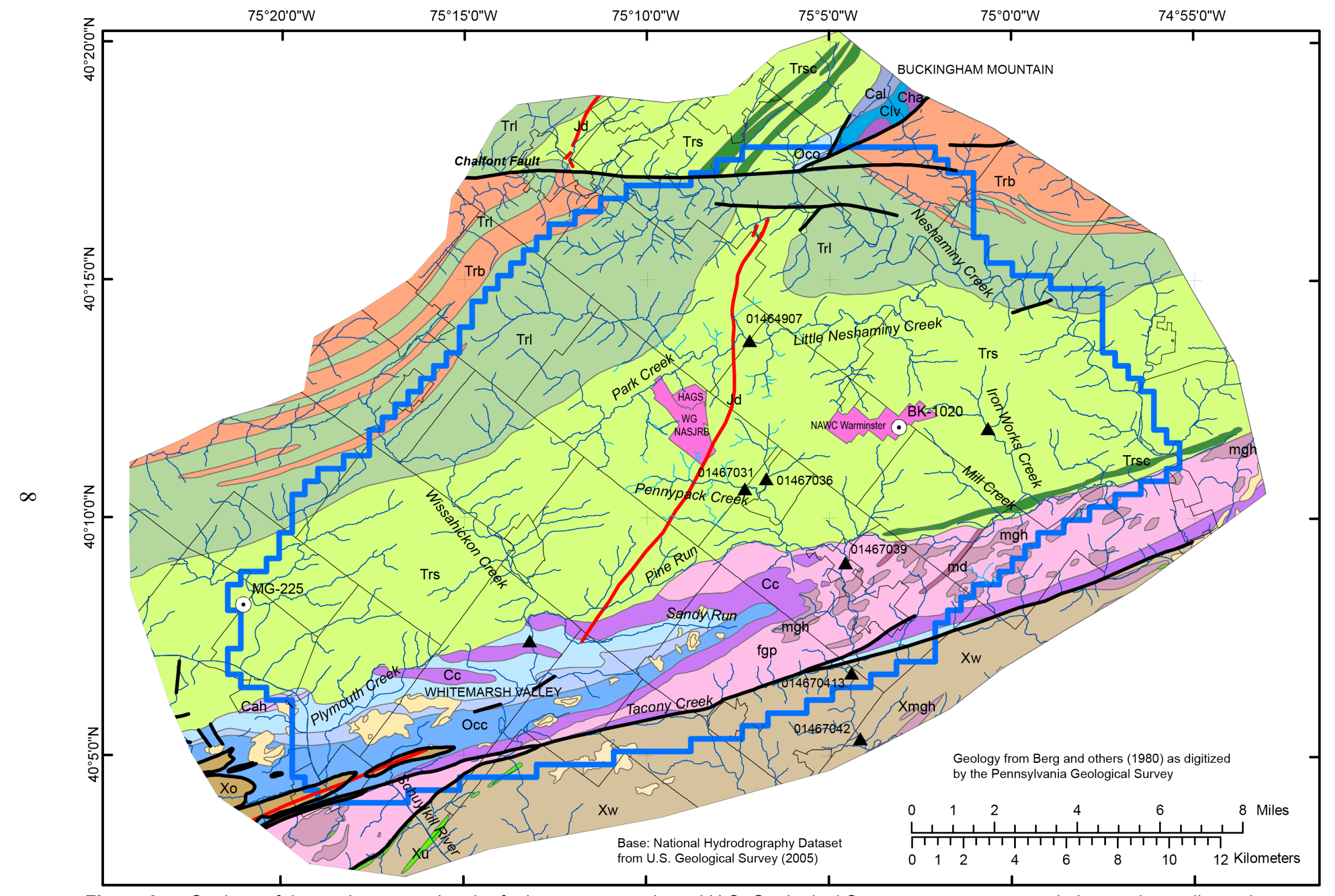

Figure 3. Geology of the study area and major faults, streams, selected U.S. Geological Survey stream gages and observation wells, and location of model grid, Bucks and Montgomery Counties, Pennsylvania. Geology and faults from Berg and others (1980). See figure 1 for names of municipalities. 


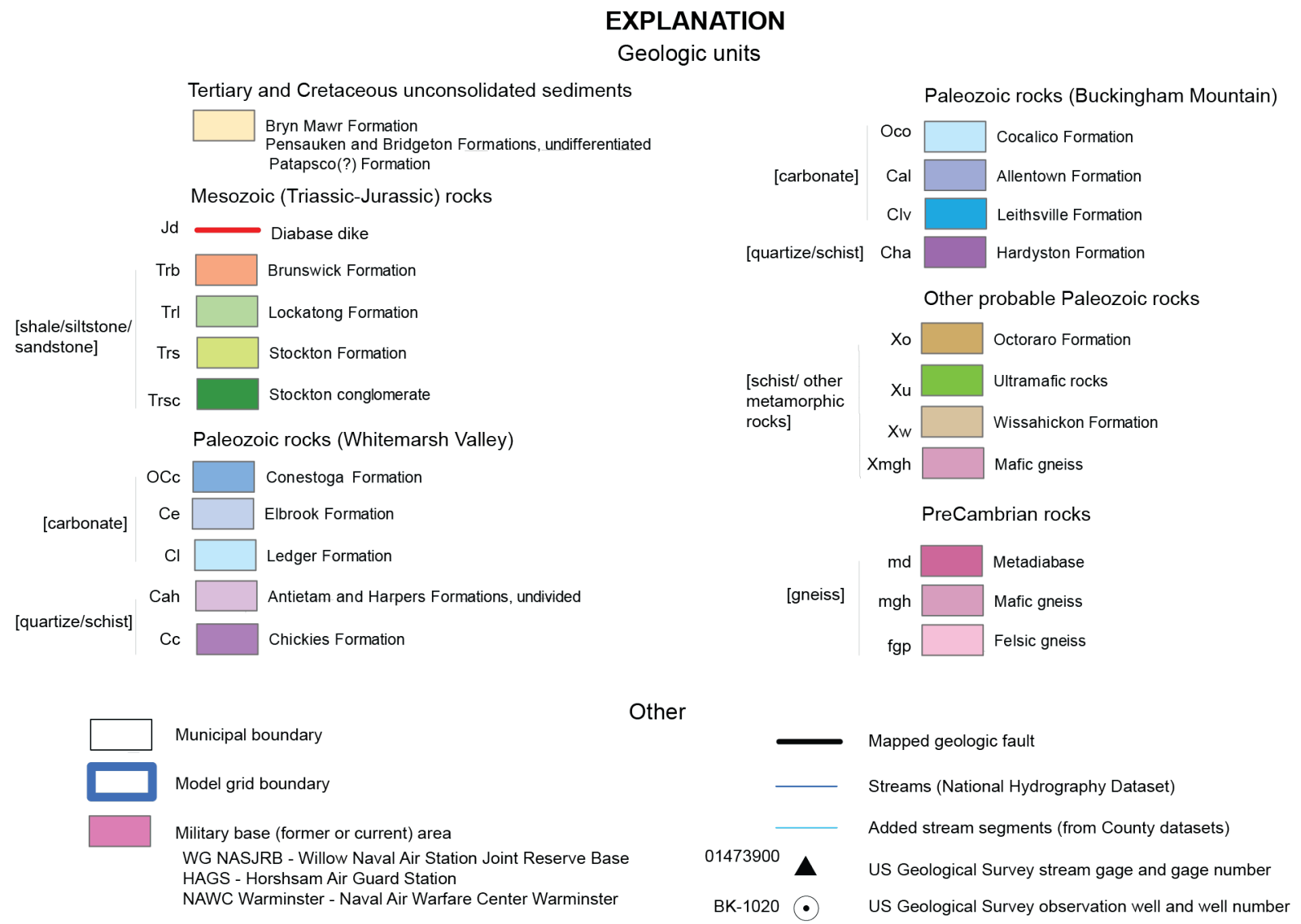

Figure 3. Geology of the study area and major faults, streams, selected U.S. Geological Survey stream gages and observation wells, and location of model grid, Bucks and Montgomery Counties, Pennsylvania. Geology and faults from Berg and others (1980).-Continued 


\section{Hydrologic Setting}

The Triassic sedimentary geologic units that underlie the study area form fractured-rock aquifers. Recharge to the fractured-rock aquifers occurs through the overlying soil and weathered rock and groundwater flows through a network of fractures both parallel and orthogonal to bedding, which commonly results in apparent preferential flow and permeability in the strike direction, parallel to bedding (Longwill and Wood, 1965). Anisotropy is the characteristic of permeability, or hydraulic conductivity, varying with direction. Lateral and vertical changes in lithology in the Stockton Formation affect the water-bearing properties of the aquifer, as finergrained deposits (shales, siltstones) commonly have lower permeability than coarser-grained deposits (sandstones and conglomerates) in the formation (Rima and others, 1962). The hydrogeology of the Stockton Formation and other geologic units of the study area have been described in more detail by Rima and others (1962), Longwill and Wood (1965), Greenman (1955), and Newport (1971). Low and others (2002) provide an overview of geohydrologic properties of the Stockton and other formations from well records and previous investigations in southeastern Pennsylvania.

Although precipitation commonly is distributed relatively evenly throughout the year, groundwater recharge varies seasonally, with the lowest recharge rates occurring when evapotranspiration rates are highest in late summer to fall, and the highest recharge rates occurring from winter to spring, as reflected in annual fluctuations in water levels. For example, in the USGS observation well BK-1020, located in the study area on NAWC Warminster (fig. 3), long-term (1975-2018) daily mean depth to water is greatest in the fall months and least in spring months (fig. 4), reflecting relatively lower and higher seasonal net recharge rates, respectively. Groundwater discharges locally to streams or to pumping wells. Streams draining the study area include the Little Neshaminy Creek, Neshaminy Creek, Pennypack Creek, Wissahickon Creek, and their tributaries (figs. 1 and 3). The area does not have glacial deposits, and no valley fill has been mapped. Streams are riffle-pool type, with some reaches underlain by exposed bedrock. Shallow stream fluvial deposits underlie some streams in the study area. Losing reaches have been identified in Little Neshaminy Creek during low-flow late summer months (Sloto and Davis, 1982). The former Willow Grove and Warminster bases lie on high ground (fig. 1) that forms topographic divides between stream basins.

Groundwater discharge rates to streams that drain areas underlain by the dipping beds of the Newark Basin may be partly controlled by geologic structure and anisotropy in hydraulic conductivity; in similar settings, groundwater discharge to streams oriented parallel to strike may be relatively less than discharge to streams oriented parallel to the dip of beds (Fan and others, 2007). 


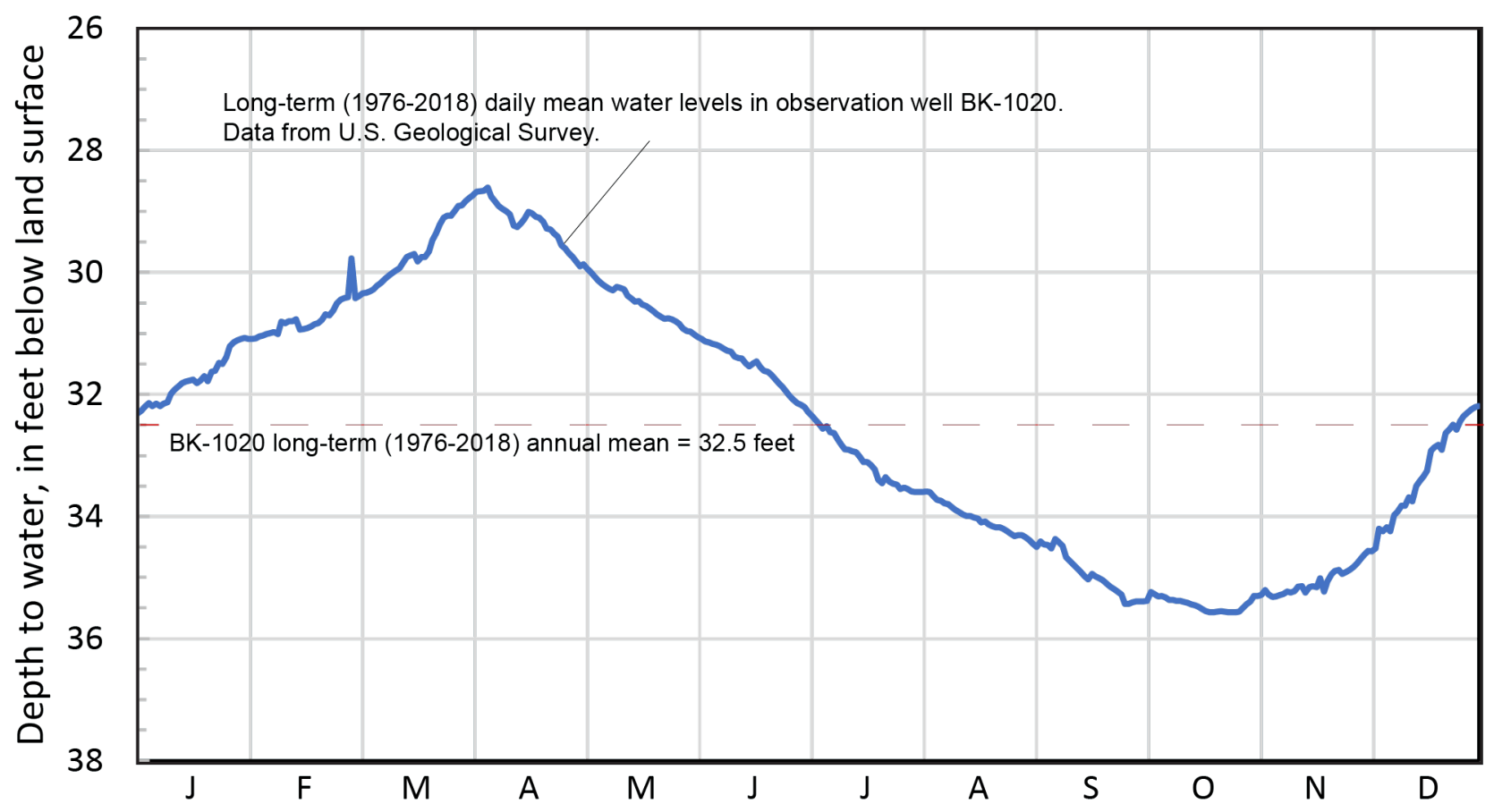

Figure 4. Long-term (1976-2018) daily mean depth to water in U.S. Geological Survey observation well BK-1020, completed in the Stockton Formation, Warminster Township, Bucks County, Pennsylvania. See figure 3 for location of well BK-1020.

\section{Hydrologic Conditions and Water Use, 1999-2017}

Hydrologic data, including precipitation, streamflow, and groundwater levels, were compiled for periods selected for groundwater model calibration $(1999,2010,2013,2016)$ and for 2017. These five periods were selected based on data availability to represent changing pumping and climatic conditions before and after PFAS contamination in groundwater was found in 2014. An extensive dataset for groundwater withdrawals (U.S. Geological Survey, 1998) and spatially distributed groundwater levels for water-table maps (Sloto and others, 2001; Rowland, 1997) for the mid- to late 1990s were available to characterize conditions for 1999, the period with the largest groundwater withdrawals in the area among time period considered (1999-2017). Year 2010 was selected because Willow Grove NASJRB, supplied by two production wells on base, was still active. Year 2013 was selected to represent conditions after Willow Grove NASJRB closed, but before nearby production wells were shut down owing to PFAS contamination in 2014. Year 2016 was selected to represent conditions when numerous production wells in the area were (or had been since 2014) shut down as result of PFAS contamination. Year 2017 was selected to represent conditions when numerous production wells in the area were shut down since 2014 or 2016 but other wells had been put back into production with treatment to remove PFAS.

Residents, institutions, industries, and commercial activities in the study area are served by public supply water systems and, in some areas, rely on individual wells for water supply. Some public supply systems import surface water from sources outside the study area. 
Wastewater in much of the study area is collected by sewers and directed to a few treatment plants that locally discharge treated wastewater to streams. Reported water use data include groundwater withdrawals and point-source discharges to streams.

\section{Precipitation}

Annual county-wide precipitation values, as determined by the National Oceanic and Atmospheric Administration (NOAA) (2018a,b) for Bucks and Montgomery Counties during the period 1990-2017 (table 1), were similar, with annual totals for Montgomery County slightly less (about 0.8 inch [in.]) than the totals for Bucks County. The 1990-2017 mean annual precipitation values of 47.56 and 46.79 in. for Bucks and Montgomery Counties, respectively, were about 2 in. (or about 4 percent) greater than the long-term (1901-2000) values of 45.50 and 44.82 in., respectively.

During 1990-2017, annual average precipitation for the two counties was more than 5 in. (or 10 percent) below long-term (1901-2000) mean values in 1992, 1997, 2001, and 2016 (relatively dry years) and more than 5 in. above long-term mean values in 1993, 1996, 2003, 2004, 2006, 2009, and 2011 (relatively wet years) (table 1; fig. 5). The two driest years were 2001 and 2016, with average values for the two counties of 37.35 and 37.55 in., about 8 in. (or about 18 percent) less than the two-county average long-term mean of $45.16 \mathrm{in}$. The two wettest years were 1996 and 2011, with average values for the two counties of 62.53 and 64.49 in., about 17 and 19 in. (or about 38 and 42 percent, respectively) greater than the two-county average long-term mean of 45.16 in.

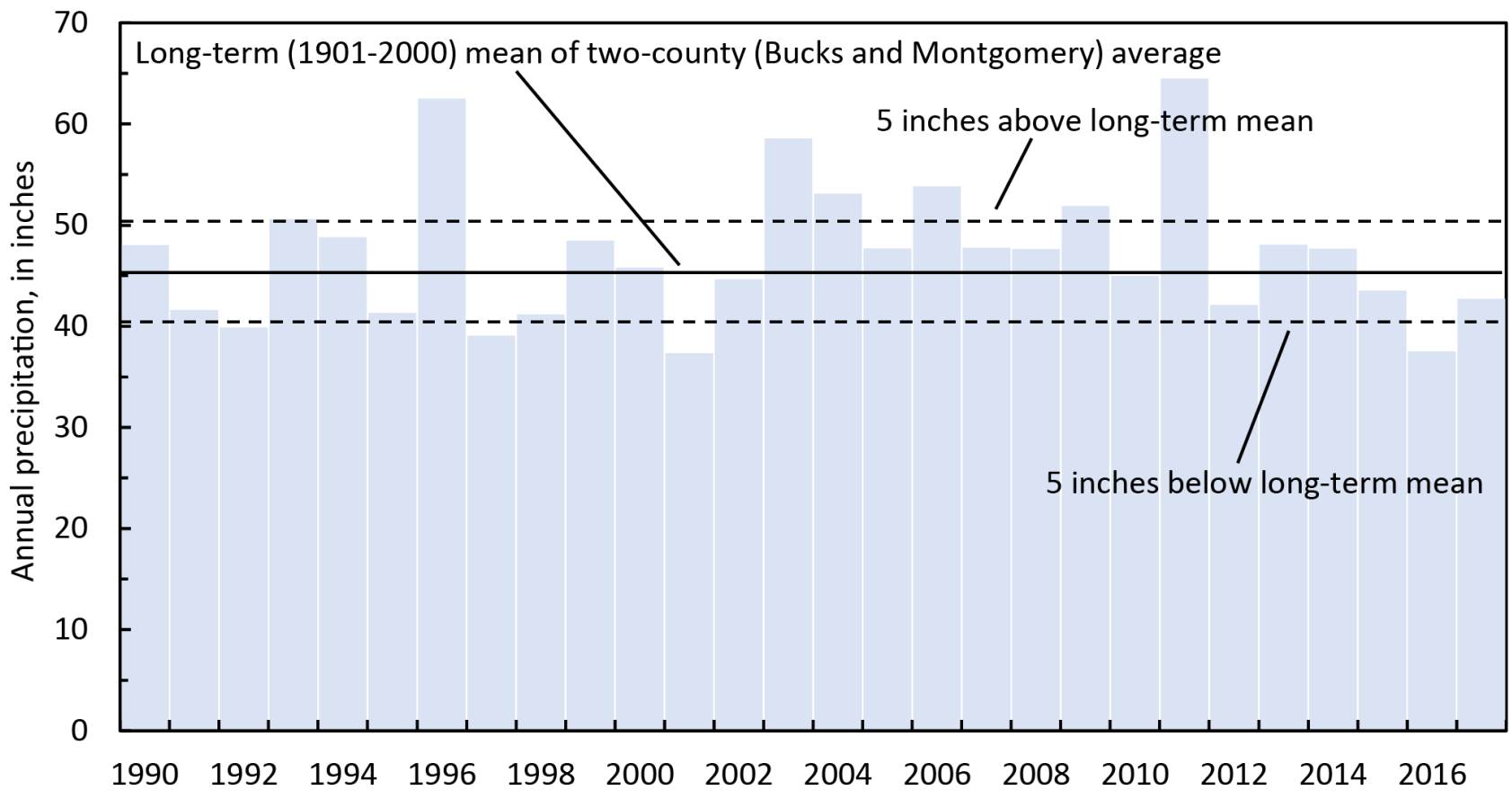

Figure 5. Mean annual total precipitation for Bucks and Montgomery Counties, Pennsylvania, 1990-2017. Data from the National Oceanic and Atmospheric Administration (2018a,b). 
Table 1. Annual total county-wide precipitation for Bucks and Montgomery Counties, Pennsylvania, 1990-2017. Data from the National Oceanic and Atmospheric Administration (2018a,b).

\begin{tabular}{|c|c|c|c|}
\hline \multirow[b]{2}{*}{ Year } & \multicolumn{3}{|c|}{ Annual precipitation, in inches } \\
\hline & Bucks County & Montgomery County & Average of two counties \\
\hline 1990 & 49.17 & 46.90 & 48.04 \\
\hline 1991 & 41.81 & 41.46 & 41.64 \\
\hline 1992 & 40.97 & 38.83 & 39.90 \\
\hline 1993 & 51.14 & 50.11 & 50.63 \\
\hline 1994 & 49.39 & 48.22 & 48.81 \\
\hline 1995 & 41.61 & 41.07 & 41.34 \\
\hline 1996 & 63.00 & 62.05 & 62.53 \\
\hline 1997 & 40.32 & 37.80 & 39.06 \\
\hline 1998 & 41.55 & 40.78 & 41.17 \\
\hline 1999 & 48.48 & 48.45 & 48.47 \\
\hline 2000 & 45.45 & 46.14 & 45.80 \\
\hline 2001 & 38.40 & 36.30 & 37.35 \\
\hline 2002 & 44.84 & 44.42 & 44.63 \\
\hline 2003 & 58.15 & 59.02 & 58.59 \\
\hline 2004 & 52.33 & 53.87 & 53.10 \\
\hline 2005 & 48.92 & 46.49 & 47.71 \\
\hline 2006 & 53.85 & 53.78 & 53.82 \\
\hline 2007 & 48.79 & 46.74 & 47.77 \\
\hline 2008 & 48.11 & 47.13 & 47.62 \\
\hline 2009 & 51.81 & 52.00 & 51.91 \\
\hline 2010 & 44.58 & 45.38 & 44.98 \\
\hline 2011 & 66.06 & 62.91 & 64.49 \\
\hline 2012 & 42.08 & 42.11 & 42.10 \\
\hline 2013 & 48.06 & 48.06 & 48.06 \\
\hline 2014 & 47.47 & 47.85 & 47.66 \\
\hline 2015 & 43.41 & 43.65 & 43.53 \\
\hline 2016 & 37.81 & 37.28 & 37.55 \\
\hline 2017 & 44.22 & 41.19 & 42.71 \\
\hline $\begin{array}{c}1990-2017 \\
\text { mean }\end{array}$ & 47.56 & 46.79 & 47.17 \\
\hline $\begin{array}{c}1901-2000 \\
\text { mean }\end{array}$ & 45.50 & 44.82 & 45.16 \\
\hline
\end{tabular}




\section{Streamflow}

Streamflow has been measured at USGS stream gages at selected sites within the model area for various periods of time (table 2). During part or all of the 1999-2017 period, stream gages within the model area were and (or) are active at one site on Little Neshaminy Creek (gage 01464907 at Valley Road), two sites on Neshaminy Creek (gages 01464750 near Rushland and 01465200 near Penns Park), four sites on Pennypack Creek (gages 01467031 at Horsham, 01467036 at Hatboro, 01467039 at Willow Grove, and 014670413 at Bethayres), one site on a tributary to Mill Creek (gage 01465460 Iron Works Creek at Richboro), and one site on Wissahickon Creek (gage 01473900 at Fort Washington) (fig. 6). Additionally, other USGS stream gages active during the 1999-2017 period at the boundary of, or just outside of, the model area are located farther downstream on Pennypack Creek (gage 01467042 at Pine Road) and both upstream and farther downstream on Neshaminy Creek (gage 01464720 North Branch at Chalfont and gage 01465500 at Langhorne, respectively) (fig. 6). Two other stream gages on Little Neshaminy (gage 01464930 Unnamed tributary to Little Neshaminy Creek at Traymore and gage 01464984 Little Neshaminy Creek at Walton Road) were active for short periods until the mid-1990s (table 2, fig. 6).

The base-flow component of streams reflects the amount of groundwater discharge to streams and can be used to estimate recharge. Base flow at selected stream gages was estimated through a hydrograph separation method using daily mean streamflow and the local-minimum option of the computer program HYSEP (Sloto and Crouse, 1986) as coded in the USGS Groundwater Toolbox (Barlow and others, 2017). Daily mean streamflow data at the USGS stream gages were obtained from the USGS National Water Information System (NWIS) database (U.S. Geological Survey, 2018). Streamflow is separated into base-flow and runoff components, as shown, for example, for monthly values at gage 01464907 Little Neshaminy Creek at Valley Road (fig. 7A,B). In southeastern Pennsylvania, natural base flow typically varies seasonally and in relation to recharge. 


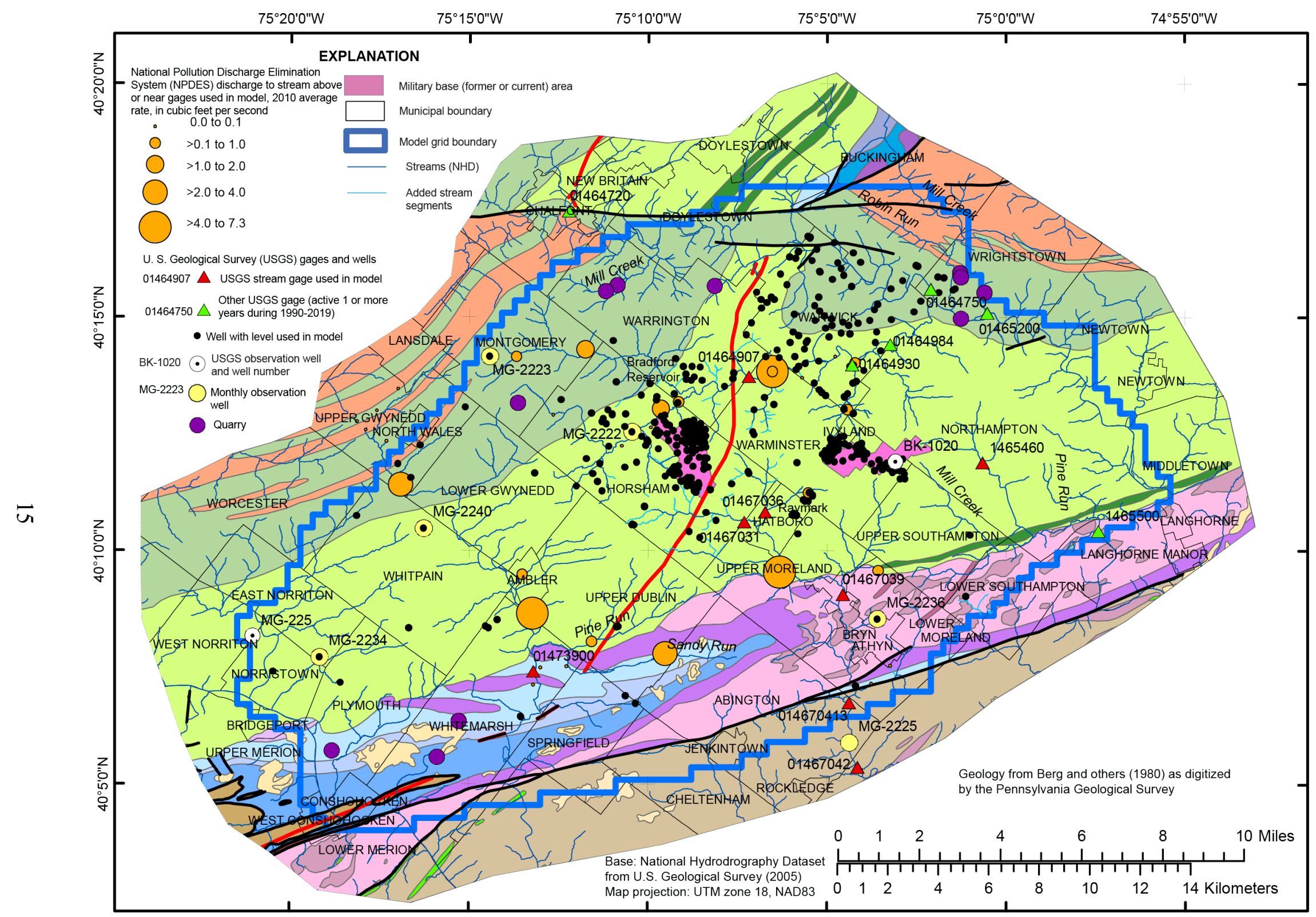

Figure 6. Location of selected U.S. Geological Survey stream gages and long-term observation wells, wells with water levels used in model calibration, selected point-source discharges (2010 rates) to streams above and near gages where data were used in model calibration, and model grid. Geology and faults from Berg and others (1980) as described in figure 3. 
Table 2. Period of record and type of data recorded for selected U.S. Geological Survey stream gages and observation wells in the study area in and near Willow Grove and Warminster, Pennsylvania, 1990-2017.

[USGS, U.S. Geological Survey; $\mathrm{mi}^{2}$, square miles; STP, sewage treatment plant; ft, feet; --, no data or not applicable]

\begin{tabular}{|c|c|c|c|c|c|c|}
\hline $\begin{array}{c}\text { USGS site } \\
\text { identification } \\
\text { number }\end{array}$ & USGS site name & $\begin{array}{l}\text { Draninage } \\
\text { area, in } \mathrm{mi}^{2}\end{array}$ & $\begin{array}{l}\text { Continuous } \\
\text { record }\end{array}$ & $\begin{array}{l}\text { Data used } \\
\text { for model } \\
\text { calibration }\end{array}$ & Begin date & End date \\
\hline
\end{tabular}

\section{Stream gages}

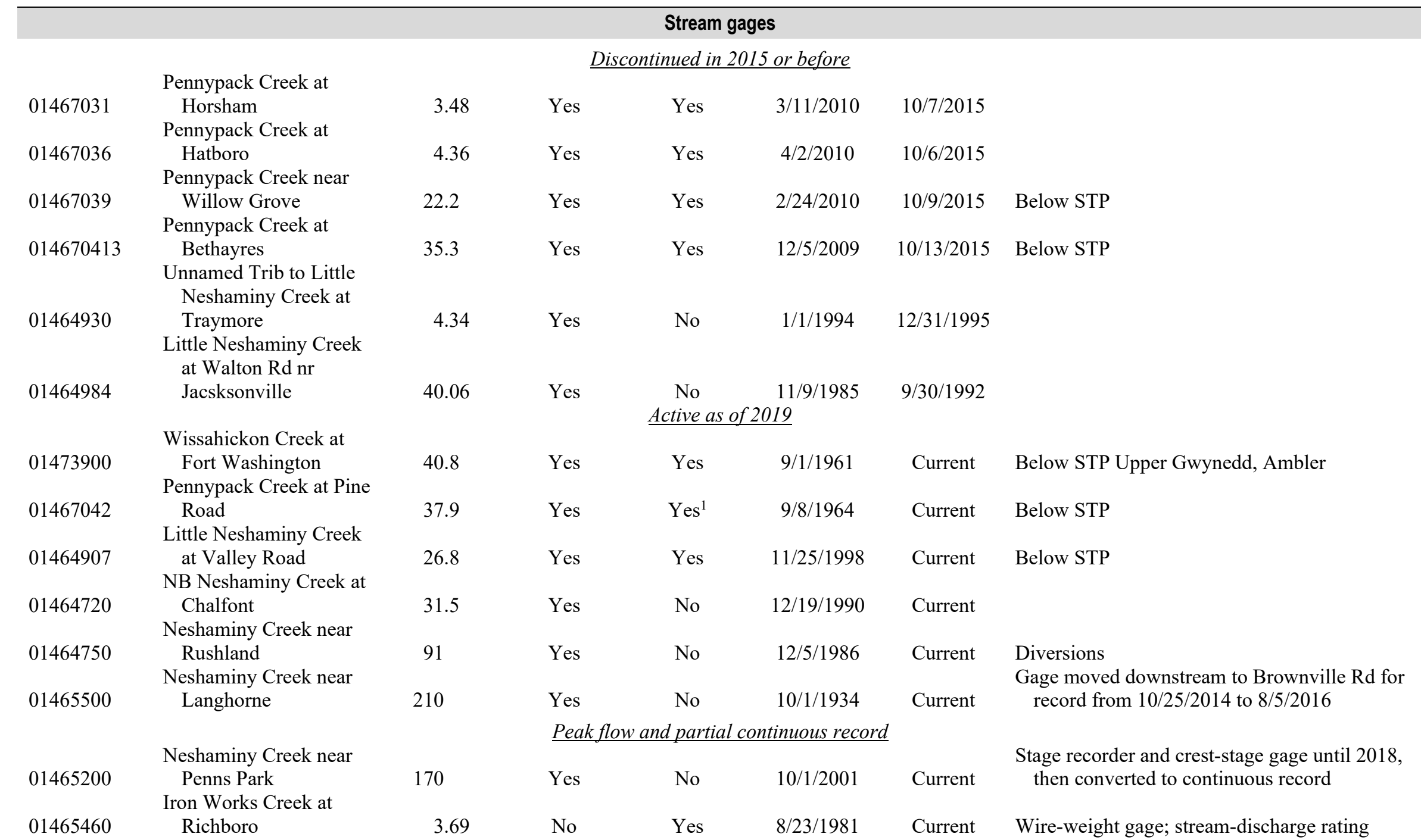


Table 2. Period of record and type of data recorded for selected U.S. Geological Survey stream gages and observation wells in the study area in and near Willow Grove and Warminster, Pennsylvania, 1990-2017.-Continued

[USGS, U.S. Geological Survey; $\mathrm{mi}^{2}$, square miles; STP, sewage treatment plant; ft, feet; --, no data or not applicable]

\begin{tabular}{|c|c|c|c|c|c|c|c|}
\hline $\begin{array}{c}\text { USGS site } \\
\text { identification } \\
\text { number }\end{array}$ & USGS site name & $\begin{array}{l}\text { Well } \\
\text { depth, } \\
\text { in ft }\end{array}$ & Type of record & $\begin{array}{l}\text { Data used } \\
\text { for model } \\
\text { calibration }\end{array}$ & Begin date & End date & Notes \\
\hline \multicolumn{8}{|c|}{ Observation wells } \\
\hline 401157075032001 & BK-1020 & 395 & Continuous & Yes & $9 / 1 / 1975$ & Current & Well completed in Stockton Fomation \\
\hline 400808075210401 & MG-225 & 486 & Continuous & Yes & 9/13/1956 & Current & Well completed in Stockton Formation \\
\hline \multicolumn{8}{|c|}{ Monthly levels - Montgomery County network } \\
\hline 401233075102701 & MG-2222 & 185 & Monthly & Yes & $7 / 1 / 2005$ & Current & Montgomery County well network \\
\hline 400554075042201 & MG-2225 & -- & Monthly & Yes & $7 / 1 / 2005$ & Current & Montgomery County well network \\
\hline 401410075142601 & MG-2233 & -- & Monthly & Yes & $7 / 1 / 2006$ & Current & Montgomery County well network \\
\hline 400743075191001 & MG-2234 & -- & Monthly & Yes & $8 / 1 / 2006$ & $3 / 1 / 2009$ & Montgomery County well network \\
\hline 400833075033501 & MG-2236 & -- & Monthly & Yes & $8 / 1 / 2006$ & Current & Montgomery County well network \\
\hline 401029075161601 & MG-2240 & -- & Monthly & Yes & $6 / 1 / 2009$ & Current & Montgomery County well network \\
\hline
\end{tabular}

${ }^{1}$ Stream flow data for gage 01467042 Pennypack Creek at Pine Road used to estimate missing 2010 data for Pennypack Creek gages 01467031, 01467036, and 01467039 for base-flow separation computations 

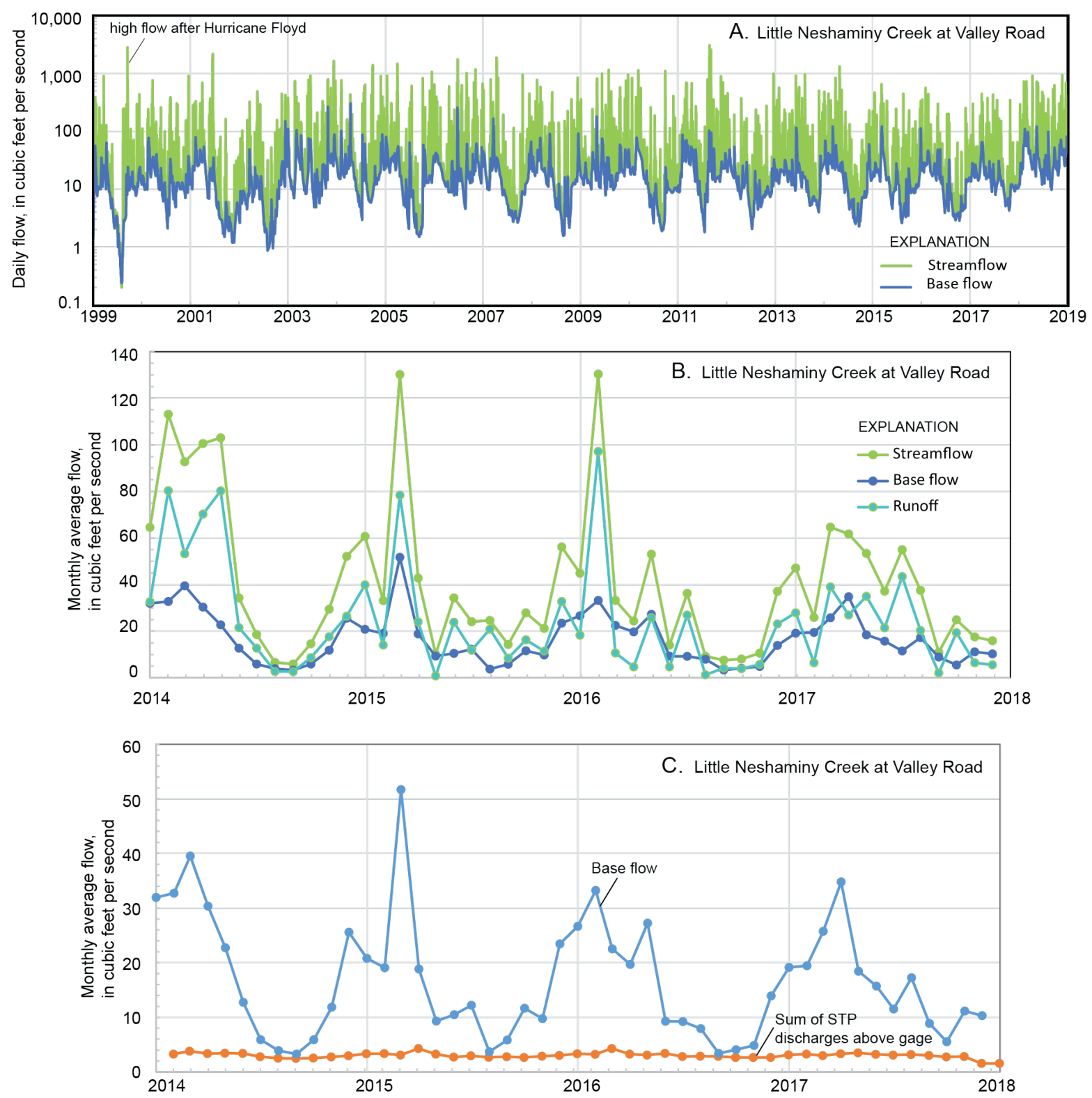

Figure 7. Data collected at gage 01464907 Little Neshaminy Creek at Valley Road and Pennypack Creek gages, where base flow was determined using the HYSEP (local-minimum option) hydrograph separation method from the U.S. Geological Survey Groundwater Toolbox (Barlow and others, 2017): A, Daily base flow and total streamflow, 1999-2018; B, Monthly base-flow and runoff components of streamflow, 2014$17 ; C$, monthly base flow and sum of reported monthly discharges from sewage treatment plants (STPs) above the gage, 2014-17; and D, base flow at gages 01467031 Pennypack Creek at Horsham, 01467036 Pennypack Creek tributary at Hatboro, and 01467039 Pennypack Creek at Willow Grove with reported discharges from National Pollution Discharge Elimination System (NPDES) sources above Hatboro gage and Upper Moreland Hatboro STP above Willow Grove gage, 2010-16. Reported monthly STP discharge flows from the Pennsylvania Department of Environmental Protection (2019a). 


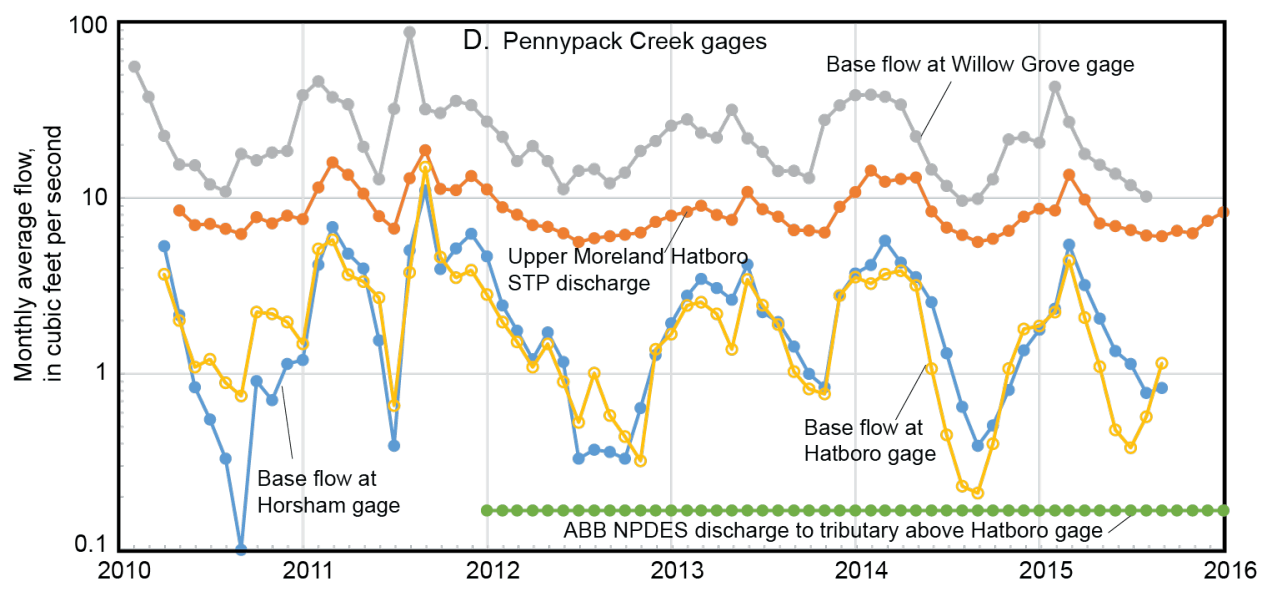

Figure 7. Data collected at gage 01464907 Little Neshaminy Creek at Valley Road and Pennypack Creek gages, where base flow was determined using the HYSEP (local-minimum option) hydrograph separation method from the U.S. Geological Survey Groundwater Toolbox (Barlow and others, 2017): $A$, Daily base flow and total streamflow, 1999-2018; B, Monthly base-flow and runoff components of streamflow, 201417; $C$, monthly base flow and sum of reported monthly discharges from sewage treatment plants (STPs) above the gage, 2014-17; and D, base flow at gages 01467031 Pennypack Creek at Horsham, 01467036 Pennypack Creek tributary at Hatboro, and 01467039 Pennypack Creek at Willow Grove with reported discharges from National Pollution Discharge Elimination System (NPDES) source above Hatboro gage and Upper Moreland Hatboro STP above Willow Grove gage, 2010-16. Reported monthly STP discharge flows from the Pennsylvania Department of Environmental Protection (2019a). - Continued

Measured flow at the streams in the study area may include point-source discharges from sewage treatment plants (STPs), quarries, or other activities. These discharges are discussed in a separate section "Discharges to Streams." Daily streamflow values used in hydrograph separation were not adjusted for discharges, and thus the estimated base flow may include discharges that are relatively steady. Apparent base flow may be affected by dams, the largest of which in the study area is the Bradford reservoir (drainage area [DA] 11 square miles [mi $\left.{ }^{2}\right]$ ) upstream of gage 01464907 Little Neshaminy Creek at Valley Road (DA $26.8 \mathrm{mi}^{2}$ ); the presence of the dam reduces peak flows and extends post-storm recession, which may result in higher amounts of post-storm apparent base flow for a few days, although the magnitude of this possible effect was not determined. Measured base flow may be reduced by groundwater withdrawals that capture some of the recharge that would otherwise contribute to base flow. Monthly baseflow values determined from daily streamflow at gage 01464907 Little Neshaminy Creek at Valley Road reflect seasonal fluctuations in addition to a component of flow contributed by one or more STPs upstream of the stream gage (fig. $7 C$ ), which is equal to base flow during some low-flow conditions common in late summer/early fall. Extreme low flows were measured in summer 1999 at gage 01464907 , but base flows subsequently rose to the near long-term average of about 18.8 cubic feet per second $\left(\mathrm{ft}^{3} / \mathrm{s}\right)\left(\right.$ median $\left.15.6 \mathrm{ft}^{3} / \mathrm{s}\right)(\mathrm{fig}$. $7 A$ ) following recharge associated with the passage of Hurricane Floyd in mid-September 1999. Base flow at gage 01464907 Little Neshaminy Creek at Valley Road also may be affected (decreased) by nearby production well pumping, as indicated by losing reaches identified in 1980 near this stream gage location when nearby production wells were pumping (Sloto and Davis, 1982, fig. 15, p. 27). 
Seasonal patterns in monthly average base flow also are indicated for 2010-15 data collected at Pennypack Creek stream gages and the Upper Moreland Hatboro STP (fig. 7D). The reported monthly average discharge from the Upper Moreland Hatboro STP is about 40 percent of the monthly base flow at gage 01467039 Willow Grove downstream. The larger amount of base flow relative to drainage area at gage 01457039 Willow Grove (DA $22.2 \mathrm{mi}^{2}$ ) compared to base flow at upstream gages 01467031 at Horsham (DA $3.48 \mathrm{mi}^{2}$ ) and 01467036 at Hatboro (DA $4.36 \mathrm{mi}^{2}$ ) partly reflects the contribution of the Upper Moreland Hatboro STP to flow at the Willow Grove stream gage. Additionally, base flow at the Pennypack Creek stream gages at Hatboro and Horsham may be reduced by nearby pumping, and at times is very small (less than $0.2 \mathrm{ft}^{3} / \mathrm{s}$ ). Base flow at gage 01467036 Hatboro during late summer 2014 was nearly equal to the reported monthly average discharge from a National Pollution Discharge Elimination System (NPDES) source (identified as "ABB") (fig. 7D) to a tributary above that stream gage (fig. 6).

Annual base flow was computed from daily streamflow data collected at one stream gage on Little Neshaminy Creek, five on Pennypack Creek, one on Iron Works Creek, and one on Wissahickon Creek (table 3, fig. 3; see appendix 1 for computation details). A few months of data for early 2010 and late 2015 were missing for four Pennypack Creek stream gages; these missing data were estimated using the complete record from downstream gage 01467042 Pennypack Creek at Pine Road (table 3; appendix 1, tables 1.2 and 1.4). Additionally, base flow at the Iron Works Creek gage was estimated from correlation of discrete flow measurements at the Iron Works Creek gage with daily mean flow and monthly base flow at the Pennypack Creek at Horsham gage (appendix 1, tables 1.4 and 1.5). The annual base flow is reported in cubic feet per second and, as normalized to drainage area, in inches (table 3). For a 19-year period of record from 1999 through 2017 at gage 01464907 Little Neshaminy Creek at Valley Road, base flow ranged from 5.47 to 13.65 in., with a median of 8.61 in.; for this same period of record, base flow ranged from about 26 to 45 percent of total streamflow with a median of about 36 percent (appendix 1, table 1.1). Of the years considered for modeling, base flow was lowest in 1999 and greatest in 2013; base flow in 2016 was slightly (about 5 percent) less than base flow in 2010 (table 3).

Similar to flow at gage 01464907 Little Neshaminy Creek at Valley Road, streamflow at the Pennypack Creek stream gages may be affected by nearby pumping and (or) STP discharges, including a relatively large STP discharge in Upper Moreland Township above the three most downstream Pennypack Creek stream gages (fig. 6). Annual base flow for 2010-15 at stream gages on Pennypack Creek below the Upper Moreland STP discharge (gages at 01467039 at Willow Grove, 014670413 at Bethayres, 01467042 at Pine Road) is from 5 to 9 in. greater than the two stream gages above this STP discharge (gages 01467031 at Horsham and 01467036 Hatboro) (table 3), reflecting the contribution of STP discharge to base flow. Base flow at gage 01473900 Wissahickon Creek at Fort Washington likely is also affected by STP discharge above the stream gage. 
Table 3. Annual average base flow at selected stream gages near Willow Grove and Warminster, Pennsylvania, 1999 and 2010-2017. Annual average base flow for calendar year computed using daily values and HYSEP local-minimum hydrograph separation method in the U.S. Geological Survey Groundwater Toolbox (Barlow and others, 2017). Estimated values (see appendix 1 for computations) in italics.

[BF, base flow; NAD83, North American Datum 1983; 1sd_ft (NAVD88), land surface datum in feet above North American Vertical Datum 1988; DA (mi²), drainage area in square miles; --, no data]

\begin{tabular}{|c|c|c|c|c|c|c|c|c|c|c|c|c|c|c|}
\hline $\begin{array}{l}\text { USGS site } \\
\text { number }\end{array}$ & USGS local site name & $\begin{array}{l}\text { Latitude } \\
\text { (NAD83) }\end{array}$ & $\begin{array}{l}\text { Longitude } \\
\text { (NAD83) }\end{array}$ & $\begin{array}{c}\text { Isd_ft } \\
\text { (NAVD88) }\end{array}$ & $\begin{array}{c}\mathrm{DA} \\
\left(\mathrm{mi}^{2}\right)\end{array}$ & 1999 & 2010 & 2011 & 2012 & 2013 & 2014 & 2015 & 2016 & 2017 \\
\hline \multirow[b]{2}{*}{01464907} & & & & & & \multicolumn{9}{|c|}{ Average base flow for calendar year in cubic feet per second } \\
\hline & $\begin{array}{l}\text { Little Neshaminy Creek at Valley Road } \\
\text { near Neshaminy }\end{array}$ & 40.22917 & -75.11972 & 190 & 26.8 & 10.95 & 15.94 & 25.15 & 13.23 & 17.12 & 18.81 & 16.44 & 15.14 & 16.45 \\
\hline 01465460 & Iron Works Creek at Richboro ${ }^{1}$ & 40.19833 & -75.01083 & 174 & 3.69 & -- & 2.24 & 3.84 & 1.24 & 1.94 & 1.83 & 1.43 & -- & -- \\
\hline 01467031 & Pennypack Creek at Horsham ${ }^{2,3}$ & 40.17722 & -75.12194 & 226 & 3.48 & -- & 2.51 & 4.52 & 1.36 & 2.36 & 2.41 & 1.88 & -- & -- \\
\hline 01467036 & Pennypack Creek tributary at Hatboro ${ }^{2,3}$ & 40.18083 & -75.11222 & 219 & 4.36 & -- & 2.34 & 4.43 & 1.17 & 1.95 & 1.89 & 1.4 & -- & -- \\
\hline 01467039 & Pennypack Creek near Willow Grove $e^{2,3}$ & 40.15139 & -75.07583 & 163 & 22.2 & -- & 24.21 & 35.2 & 18.3 & 21.73 & 23.61 & 18.67 & -- & -- \\
\hline 014670413 & Pennypack Creek at Bethayres ${ }^{3}$ & 40.11278 & -75.07306 & 94 & 35.3 & -- & 37.54 & 43.36 & 29.2 & 33.51 & 37.28 & 26.02 & -- & -- \\
\hline 01467042 & Pennypack Creek at Pine Road & 40.08972 & -75.06917 & 79 & 37.9 & -- & 41.03 & 50.98 & 31.34 & 35.29 & 39.12 & 28.95 & 25.28 & -- \\
\hline 01473900 & Wissahickon Creek at Fort Washington & 40.12389 & -75.22000 & 139 & 40.8 & -- & 37.82 & 49.62 & 30.87 & 38.83 & 41.78 & 29.16 & 27.23 & -- \\
\hline
\end{tabular}
01464907 Little Neshaminy Creek at Valley Road near Neshaminy

01465460 Iron Works Creek at Richboro ${ }^{1}$

01467031 Pennypack Creek at Horsham ${ }^{2,3}$

01467036 Pennypack Creek tributary at Hatboro ${ }^{2,3}$

01467039 Pennypack Creek near Willow Grove ${ }^{2,3}$

014670413 Pennypack Creek at Bethayres ${ }^{3}$

$01467042 \quad$ Pennypack Creek at Pine Road

$01473900 \quad$ Wissahickon Creek at Fort Washington

$\begin{array}{ll}40.22917 & -75.11972 \\ 40.19833 & -75.01083 \\ 40.17722 & -75.12194 \\ 40.18083 & -75.11222 \\ 40.15139 & -75.07583 \\ 40.11278 & -75.07306 \\ 40.08972 & -75.06917 \\ 40.12389 & -75.22000\end{array}$

$\underline{\text { Average base flow for calendar year in inches }}$

${ }^{1}$ Iron Works base flow estimated from discrete measurements at site correlated with daily values at Horsham; then applying that correlation to base flow at Horsham.

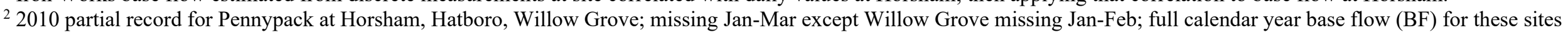
estimated from correlation with 2010 Pine Rd monthly BF values (cubic feet per second).

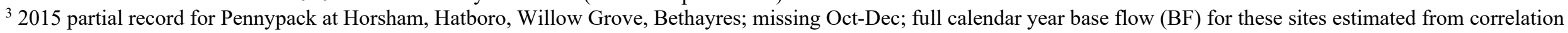
with 2015 Pine Rd monthly BF values (cubic feet per second). 


\section{Groundwater Levels}

Wells with water-level measurements included residential wells, monitoring wells, and unused production wells. In the study area, residential and production wells typically are drilled into bedrock, with the casing extended to the depth of competent bedrock, and the remaining depth of the hole left open. Water-producing fractures may be present throughout the open interval. Monitoring wells are initially drilled as open holes but are commonly reconstructed to be open to only relatively short intervals of about $20 \mathrm{ft}$ of aquifer thickness. Monitoring wells are generally shallower in depth than residential or production wells.

Data on groundwater levels in the study area for the period of interest include one-time USGS measurements in wells that were used to prepare water-table maps for Warwick Township during 1994-95 (Rowland, 1997), at and near Willow Grove during October 1999 (Sloto and others, 2001), and in Upper Gwynedd in 2000 (Senior and Ruddy, 2004). Other data include groundwater levels in wells inventoried by the USGS for various studies, monthly measurements in selected wells in Montgomery County (Montgomery County Department of Health and Human Services, Horsham Water and Sewer Authority [HWSA]), and periodic measurements in monitoring wells at the former NAWC Warminster (U.S. Navy and their consultants), Willow Grove NASJRB (U.S. Navy and consultants), HAGS (Air National Guard and consultants) and Raymark Superfund site (EPA and Pennsylvania Department of Environmental Protection [PADEP]) in Hatboro. Sources of well-construction and water-level data are identified by well in a data release (Senior and others, 2020). The data were compiled by the USGS during 2017-19 from the USGS NWIS database (U.S. Geological Survey, 2018), previous reports (H\&S Environmental, Inc., 2012; CDM Federal Programs Corporation, 2003; Gilmore and Associates, Inc., 2015; Koman Government Solutions, LLC, 2018a; Leidos, 2018; Resolution Consultants, 2019), or from written communications (Toby Kessler, Gilmore Associates, Inc. for HWSA data; Andrew Barton, Battelle Memorial Institute, for 2015 data in Area B of NAWC Warminster; Colin Wade, PADEP, for water-level data at Raymark).

Additionally, the USGS collects continuous data in two long-term observation wells in the study area, both completed in the Stockton Formation: well BK-1020 on the east edge of the former NAWC Warminster base and well MG-225 in the southwest edge of the study area (figs. 3 and 6). Monthly water levels for wells in the Montgomery County network are available in the USGS NWIS database and five of these wells are in the study area (fig. 6). Water-level data are plotted in hydrographs of groundwater levels in observation well BK-1020 (fig. $8 A, B$ ) and water levels in five Montgomery County network wells (fig. $8 B$ ). Among the wells with continuous or monthly data, annual seasonal fluctuations in groundwater levels are greatest in well BK-1020, ranging from 10 to $15 \mathrm{ft}$, but the pattern of seasonal fluctuations in groundwater levels is similar for all the wells (fig. 8B). Mean annual water-level values for well BK-1020, MG-225, and the Montgomery County network wells were used for model calibration datasets, as listed in Senior and others (2020). For other wells with more than one measurement per year, the average water level was used for that year model calibration. 


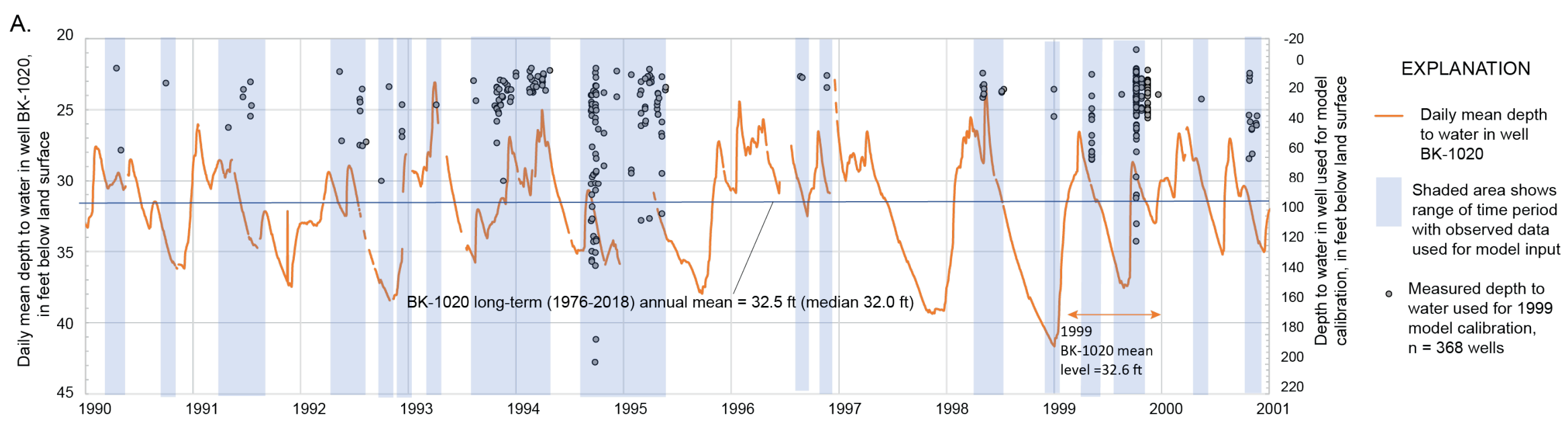

B.

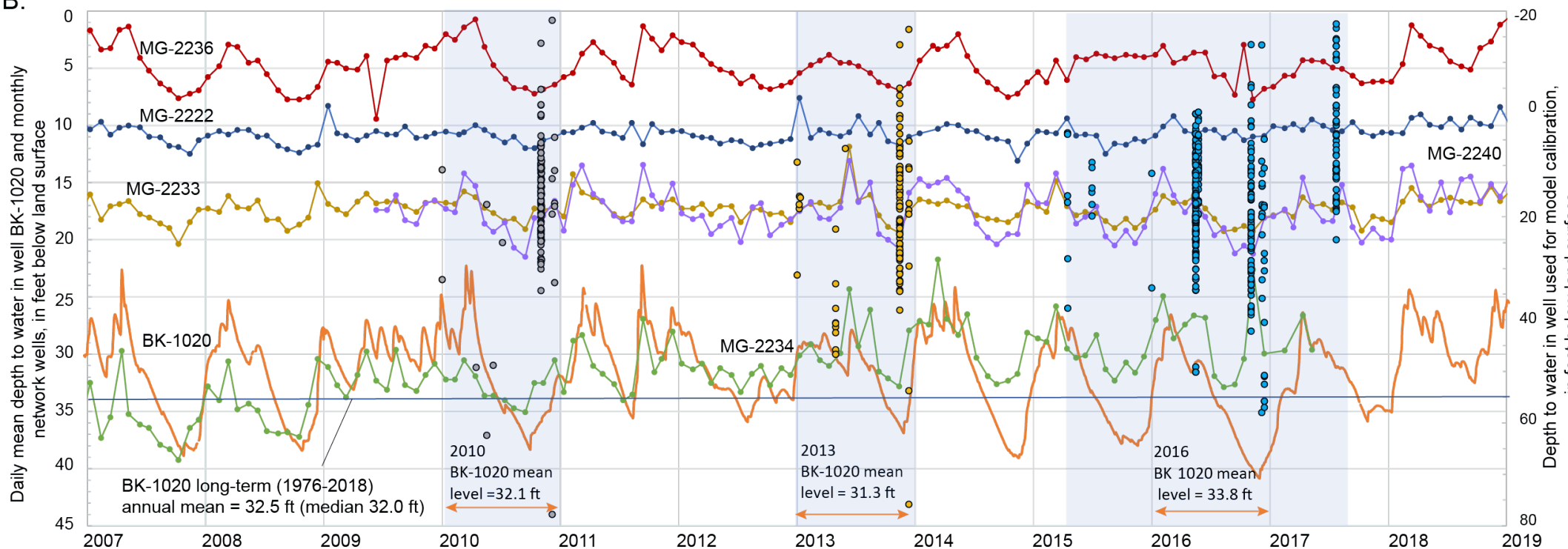

EXPLANATION Depth to water used for mode calibration by year 2010,
$n=123$ wells - 2013, $\mathrm{n}=121$ wells - 2016, $n=397$ wells

Figure 8. Groundwater levels in well BK-1020 and five Montgomery County network wells, as well as groundwater-level data used for model calibration in the time periods selected to represent calendar years $A, 1999$, and $B, 2010,2013$, and 2016 conditions. Montgomery County network wells include MG-2222, MG-2233, MG-2234, MG-2236, and MG-2240. 
Groundwater-level data collected by the USGS during the 1990s have a larger spatial distribution in the study area than subsequent data as a result of USGS data collection for countywide assessments, water-table maps, and other studies. To represent conditions in 1999, data from 1990 to 2000 were compiled, with the objective of obtaining broad spatial distribution while minimizing periods of extreme high or low seasonal values indicated by water levels in long-term observation well BK-1020 (fig. 8A). Fewer and (or) less spatially distributed water level-data were available for years 2010, 2013, and 2016. To represent the 2016 conditions, water levels measured during 2015-17 were compiled, including levels measured in monitoring wells on the former Willow Grove NASJRB, NAWC Warminster, and HAGS from 2015-17 (fig. 8B). Mean water levels in well BK-1020 were lower in 1999 and 2016 than in 2010 and 2013 (fig. 8A,B), consistent with lower base flow (and inferred recharge) for those years, respectively.

Summary statistics for a total of 670 wells with water levels used to characterize conditions for the 1999, 2010, 2013, and 2016 model scenarios show that the median depth to the top of the open interval was about $52 \mathrm{ft}$ below land surface (bls) and the median depth to the bottom of the open interval was about $90 \mathrm{ft}$ bls for wells with known or reported well construction information (558 wells had a known depth to the top of the interval and 602 wells had a known depth to the bottom of the interval) (table 4). For wells with missing construction information, the depth of the open interval was estimated as described in Senior and others (2020). If not known, the depth to the bottom of the open interval was estimated to be $150 \mathrm{ft} \mathrm{bls.} \mathrm{If} \mathrm{not} \mathrm{known,} \mathrm{the} \mathrm{depth}$ to the top of the open interval was estimated to be $40 \mathrm{ft}$ bls for wells greater than $80 \mathrm{ft}$ in depth, 30 $\mathrm{ft}$ bls for wells 65 to $79 \mathrm{ft}$ in depth, $20 \mathrm{ft}$ for wells 40 to $64 \mathrm{ft}$ in depth, $15 \mathrm{ft}$ for wells 30 to $39 \mathrm{ft}$ in depth, $10 \mathrm{ft}$ for wells 19 to $29 \mathrm{ft}$ in depth, and about half the depth to the bottom of the open interval for wells less than $19 \mathrm{ft}$ in depth. Statistics for open intervals of all wells, including estimated values for missing construction data, used for model input are similar to statistics for open intervals for wells without estimated values (table 4). Water levels ranged from about $200 \mathrm{ft}$ below land surface to $23 \mathrm{ft}$ above land surface (negative values, such as $-23 \mathrm{ft}$, indicate the water level is above land surface). The median depth to water ranged from about 15.7 to $18.5 \mathrm{ft}$ bls. Depth to water commonly varies by topographic setting, with the depth to water greater at hilltops than in valley settings (Low and others, 2002). Depth to water also may be affected by nearby pumping, such as in the cones of depression shown near pumping production wells in the Warwick Township potentiometric-surface map (Rowland, 1997). 
Table 4. Summary statistics for wells with water levels used in model calibration scenarios for 1999, 2010, 2013, and 2016 conditions, including land-surface altitude, depth to top and bottom of well opening, date of water-level measurement, and depth to water near Willow Grove and Warminster, Pennsylvania.

[LSA_ft (NAVD88), land-surface altitude in feet above North American vertical datum of 1988, Top Open Depth (ft), depth to top of well opening in feet below land surface; Bottom open depth (ft), depth to top of well opening in feet below land surface; Date_WL, date of water-level measurement; DTW below MP (ft), depth to water, in feet below measuring point; MPA_ft, measuring point altitude, in feet above NAVD88; --, no data]

\begin{tabular}{|c|c|c|c|c|c|c|}
\hline $\begin{array}{l}\text { Summary } \\
\text { statistics }\end{array}$ & $\begin{array}{c}\text { LSA ft } \\
\text { (NAVD88) }\end{array}$ & $\begin{array}{l}\text { Top open } \\
\text { depth (ft) }\end{array}$ & $\begin{array}{c}\text { Bottom } \\
\text { open depth } \\
\text { (ft) }\end{array}$ & Date_WL & $\begin{array}{c}\text { DTW } \\
\text { below MP } \\
\text { (ft) }\end{array}$ & $\begin{array}{c}\text { MPA ft } \\
\text { (NAVD88) }\end{array}$ \\
\hline \multicolumn{7}{|c|}{ No estimated values for well construction included in statistics } \\
\hline \multicolumn{7}{|c|}{ All wells with water levels used for $1999,2010,2013$ and 2016 conditions, $\mathrm{n}=670$} \\
\hline Count, $\mathrm{n}=$ & 670 & 558 & 602 & -- & -- & -- \\
\hline Minimum & 116 & 4 & 6 & -- & -- & -- \\
\hline 10th percentile & 249 & 14 & 31 & -- & -- & -- \\
\hline Mean & 307 & 74 & 138 & -- & -- & -- \\
\hline Median & 313 & 52 & 90 & -- & -- & -- \\
\hline 90th percentile & 357 & 169 & 330 & -- & -- & -- \\
\hline Maximum & 455 & 360 & 2148 & -- & -- & -- \\
\hline \multicolumn{7}{|c|}{ Estimated values for well construction included in statistics } \\
\hline \multicolumn{7}{|c|}{ All wells with water levels used for $1999,2010,2013$ and 2016 conditions, $n=670$} \\
\hline Minimum & 116 & 3 & 6 & -- & -- & -- \\
\hline 10th percentile & 249 & 15 & 32 & -- & -- & -- \\
\hline Mean & 307 & 68 & 139 & -- & -- & -- \\
\hline Median & 313 & 40 & 100 & -- & -- & -- \\
\hline 90th percentile & 357 & 157 & 311 & -- & -- & -- \\
\hline Maximum & 455 & 360 & 2148 & -- & -- & -- \\
\hline \multicolumn{7}{|c|}{ Wells with water levels used for 1999 conditions, $\mathrm{n}=368$} \\
\hline Minimum & 116 & 3 & 6 & $4 / 16 / 1990$ & -12.46 & 116 \\
\hline 10th percentile & 224 & 18 & 38 & $11 / 5 / 1993$ & 5.00 & 225 \\
\hline Mean & 303 & 56 & 158 & $2 / 23 / 1997$ & 27.17 & 304 \\
\hline Median & 313 & 40 & 135 & $5 / 8 / 1998$ & 17.05 & 313 \\
\hline 90th percentile & 359 & 115 & 332 & $11 / 15 / 1999$ & 68.84 & 359 \\
\hline Maximum & 444 & 278 & 2148 & $12 / 11 / 2001$ & 198.68 & 459 \\
\hline \multicolumn{7}{|c|}{ Wells with water levels used for 2010 conditions, $n=123$} \\
\hline Minimum & 164 & 6 & 35 & $1 / 1 / 2010$ & -18.15 & 164 \\
\hline 10th percentile & 285 & 18 & 45 & $11 / 2 / 2010$ & 5.98 & 285 \\
\hline Mean & 307 & 57 & 114 & $10 / 28 / 2010$ & 18.15 & 307 \\
\hline Median & 312 & 45 & 86 & $11 / 2 / 2010$ & 16.59 & 312 \\
\hline 90th percentile & 328 & 109 & 200 & $11 / 4 / 2010$ & 28.62 & 328 \\
\hline Maximum & 455 & 189 & 580 & $12 / 14 / 2010$ & 103.60 & 455 \\
\hline
\end{tabular}


Table 4. Summary statistics for wells with water levels used in model calibration scenarios for 1999, 2010, 2013, and 2016 conditions, including land-surface altitude, depth to top and bottom of well opening, date of water-level measurement, and depth to water near Willow Grove and Warminster, Pennsylvania.-Continued

[LSA_ft (NAVD88), land-surface altitude in feet above North American vertical datum of 1988, Top Open Depth (ft), depth to top of well opening in feet below land surface; Bottom Open Depth (ft), depth to top of well opening in feet below land surface; Date_WL, date of water-level measurement; DTW below MP (ft), depth to water, in feet below measuring point; MPA_ft, measuring point altitude, in feet above NAVD88]

\begin{tabular}{|c|c|c|c|c|c|c|}
\hline $\begin{array}{l}\text { Summary } \\
\text { statistics }\end{array}$ & $\begin{array}{c}\text { LSA_ft } \\
\text { (NAVD88) }\end{array}$ & $\begin{array}{l}\text { Top open } \\
\text { depth (ft) }\end{array}$ & $\begin{array}{c}\text { Bottom } \\
\text { open depth } \\
\text { (ft) }\end{array}$ & Date_WL & $\begin{array}{c}\text { DTW } \\
\text { below MP } \\
\text { (ft) }\end{array}$ & $\begin{array}{c}\text { MPA ft } \\
\text { (NAVD88) }\end{array}$ \\
\hline \multicolumn{7}{|c|}{ Estimated values for well construction included in statistics } \\
\hline \multicolumn{7}{|c|}{ Wells with water levels used for 2013 conditions, $n=121$} \\
\hline Minimum & 164 & 14 & 38 & $1 / 1 / 2013$ & -16.40 & 164 \\
\hline 10th percentile & 235 & 20 & 46 & $4 / 30 / 2013$ & 6.15 & 235 \\
\hline Mean & 305 & 61 & 115 & $10 / 16 / 2013$ & 20.90 & 305 \\
\hline Median & 311 & 47 & 87 & $11 / 14 / 2013$ & 18.48 & 311 \\
\hline 90th percentile & 328 & 122 & 200 & $11 / 14 / 2013$ & 34.47 & 328 \\
\hline Maximum & 357 & 190 & 580 & $12 / 12 / 2013$ & 102.00 & 357 \\
\hline \multicolumn{7}{|c|}{ Wells with water levels used for 2016 conditions, $n=397$} \\
\hline Minimum & 164 & 4 & 10 & $4 / 16 / 2015$ & -23.20 & 164 \\
\hline 10th percentile & 272 & 11 & 26 & $5 / 16 / 2016$ & 2.33 & 273 \\
\hline Mean & 312 & 78 & 109 & $9 / 1 / 2016$ & 16.46 & 313 \\
\hline Median & 313 & 52 & 80 & $5 / 24 / 2016$ & 15.79 & 314 \\
\hline 90th percentile & 352 & 186 & 242 & $7 / 24 / 2017$ & 30.83 & 354 \\
\hline Maximum & 455 & 360 & 580 & $7 / 24 / 2017$ & 101.63 & 455 \\
\hline
\end{tabular}




\section{Groundwater Withdrawals}

Groundwater has been a major source of supply for public drinking water, commercial, and industrial uses in the study area, with withdrawal rates increasing as the area started to urbanize in the 1950s (Sloto and Davis,1982). Additionally, pumping for remediation of groundwater contamination started in the 1990s at various locations, including at the Raymark Superfund site in Hatboro (U.S. Environmental Protection Agency, 2006; CDM Federal Programs Corporation, 2003), at two industrial properties (CRC and the former Fisher Porter, now ABB) in Warminster, and at the former NAWC Warminster. Other groundwater withdrawals in the study area are associated with quarry dewatering operations; most quarries in the study area are in the Lockatong Formation or Paleozoic carbonate rocks (some of which are indicated by areas of negative values of mapped land-surface altitude as much as $-275 \mathrm{ft}[-84 \mathrm{~m}]$ relative to the North American Vertical Datum of 1988 [NAVD88] in fig. 1).

The study area is within the Delaware River Basin Commission (DRBC) Southeastern Pennsylvania Ground Water Protected Area (GWPA), where regulations that affect groundwater withdrawals greater than 10,000 gallons per day (gal/d) have been in effect since 1980. The GWPA includes all of Montgomery County, the southwestern half of Bucks County, and smaller parts of adjacent counties and was established by the DRBC to address concerns that groundwater withdrawals were resulting in undesirable lower water levels and base flow (Delaware River Basin Commission, 1980).

Data on groundwater withdrawals in the study area were compiled from various sources including the DRBC, Pennsylvania Department of Environmental Protection (PADEP), and water suppliers. Annual average withdrawals by wells and quarries and sources of withdrawal data are described in more detail in the data release for this report (Senior and others, 2020). Withdrawal rates were compiled by the USGS for a water-use assessment (Solley and others, 1998) using available data in 1996 and documented by the USGS (U.S. Geological Survey, 1998) for the DRBC (Delaware River Basin Commission, 2019) to assist in a 1998 assessment of water resources. Those withdrawals were used by this study for 1999 conditions. Withdrawal rates reported to PADEP (2019b) were used to represent the 2010, 2013, 2016, and 2017 conditions and are listed with well construction information by Senior and others (2020). Additional information about withdrawal rates for groundwater remediation extraction wells at NAWC Warminster were compiled from various reports prepared for the Navy (Koman Government Solutions, LLC, 2018a,b,c) and for extraction wells at Raymark from the EPA (2006). The compiled data represent groundwater withdrawals reported to either the DRBC or PADEP and may not include some withdrawals not reported to these agencies, as water use less than 10,000 $\mathrm{gal} / \mathrm{d}$ is not required to be reported to the DRBC. For example, residential water use (estimated to be about 60 gal/d per person) and some withdrawals for golf course irrigation are not reported; however, in the case of residential wells, withdrawals are considered relatively small and any consumptive effect is negligible if the residence has on-lot wastewater disposal and withdrawals are returned to the groundwater. Quarry withdrawals for dewatering purposes commonly are discharged to nearby streams. Complete data on withdrawal rates for quarries are not available from PADEP sources (Pennsylvania Department of Environmental Protection, 2019b,c) for the periods of interest and were estimated in some cases, where data were missing as described in Senior and others (2020). At least two of the quarries (Glasgow Ivy Rock and Glasgow Montgomery) in the model area currently (2019) are used for clean fill and thus presumed to be inactive, with little to no dewatering. Permitted values for quarry discharge (Michael Kutney, 
Pennsylvania Department of Environmental Protection Bureau of District Mining Operations, written commun., 2018) were used to confirm magnitude of likely quarry withdrawals.

Production wells typically are constructed as open holes in the study area, and are usually 8 to $12 \mathrm{in}$. in diameter with depths of 300 to $400 \mathrm{ft}$ but can be as deep as 600 to $700 \mathrm{ft}$. Remedial extraction wells commonly are 6 in. in diameter and relatively shallow (less than $200 \mathrm{ft}$ deep). For all 306 pumping wells included in the data compilation, the median depth to the top of opening (equivalent to the depth of casing) is $50 \mathrm{ft}$ and the median depth to the bottom of the well is $301 \mathrm{ft}$ (table 5). The distribution of well depths in the compiled data shows that most wells are drilled to depths of 300 to $400 \mathrm{ft}$ (fig. 9A). Pumping rates range widely in wells of various depths but tend to be lower in shallow wells commonly drilled for remediation purposes and greater in deeper wells drilled for production and supply (fig. 9B).
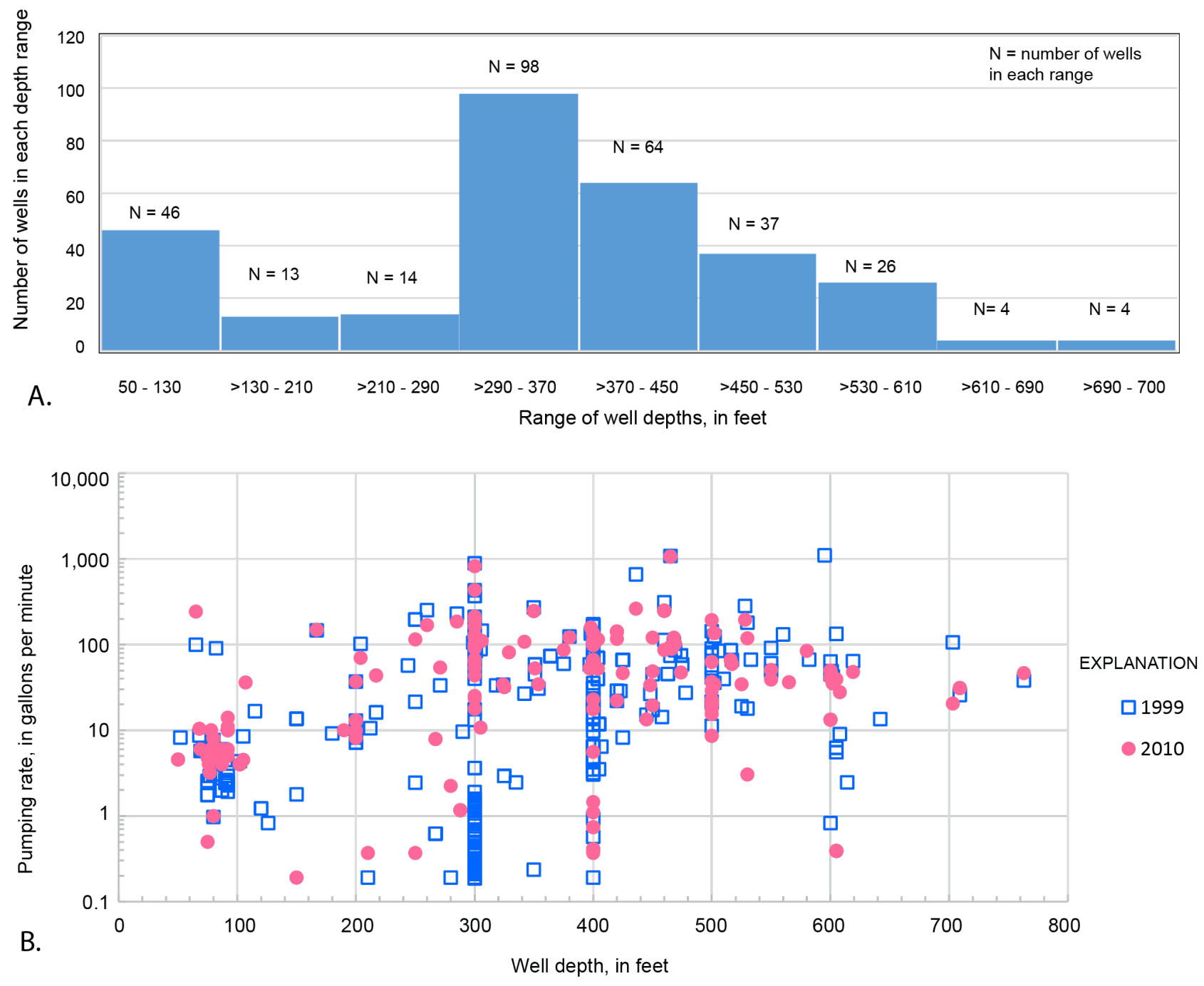

Figure 9. $A$, Distribution of well depths and $B$, relation between well depths and reported pumping rates for withdrawal wells in 1999 and 2010 in the model area near Willow Grove and Warminster, Pennsylvania. 
Table 5. Summary statistics for pumping wells with withdrawals used in model scenarios for 1999, 2010, 2013, 2016 and 2017 conditions, including land-surface altitude and depth to top and bottom of well opening, near Willow Grove and Warminster, Pennsylvania.

[LSA_ft (NAVD88), land-surface altitude in feet above North American vertical datum of 1988; Top Open Depth (ft), depth to top of well opening in feet below land surface; Bottom Open Depth (ft), depth to top of well opening in feet below land surface]

\begin{tabular}{|c|c|c|c|}
\hline Summary statistics & $\begin{array}{l}\text { LSA_ft } \\
\text { (NAVD88) }\end{array}$ & $\begin{array}{l}\text { Top open } \\
\text { depth (ft) }\end{array}$ & $\begin{array}{l}\text { Bottom open } \\
\text { depth (ft) }\end{array}$ \\
\hline \multirow{2}{*}{\multicolumn{4}{|c|}{$\begin{array}{l}\text { No estimated values for well construction included in statistics } \\
\text { All pumping wells with withdrawals during one or more years } \\
\text { during } 1999,2010,2013,2016 \text {, and } 2017\end{array}$}} \\
\hline & & & \\
\hline Count, $n=$ & 306 & 204 & 237 \\
\hline Minimum & 59 & 10 & 50 \\
\hline 10th percentile & 179 & 19 & 81 \\
\hline Mean & 260 & 53 & 347 \\
\hline Median & 259 & 50 & 351 \\
\hline 90th percentile & 336 & 80 & 593 \\
\hline Maximum & 499 & 424 & 763 \\
\hline \multicolumn{4}{|c|}{ Estimated values for well construction included in statistics } \\
\hline \multicolumn{4}{|c|}{$\begin{array}{l}\text { All pumping wells with withdrawals during one or more years } \\
\text { during } 1999,2010,2013,2016 \text {, and } 2017\end{array}$} \\
\hline Count, $n=$ & 306 & 306 & 306 \\
\hline Minimum & 59 & 10 & 50 \\
\hline 10th percentile & 179 & 21 & 90 \\
\hline Mean & 260 & 52 & 343 \\
\hline Median & 259 & 50 & 301 \\
\hline 90th percentile & 336 & 70 & 550 \\
\hline Maximum & 499 & 424 & 763 \\
\hline
\end{tabular}


In the study area, reported annual withdrawals for supply purposes have declined since the 1990s from rates of about 20 million gallons per day (Mgal/d) to about $10.5 \mathrm{Mgal} / \mathrm{d}$ in 2017 (table 6; fig. 10). Total reported withdrawals for quarry dewatering in the study area has remained relatively constant during 1995-2017 at rates of about 9 to $10 \mathrm{Mgal} / \mathrm{d}$, but pumping has varied by quarry. Although groundwater has been, and continues to be, a major source of drinking water supply in the area, some municipalities and water purveyors began to import surface water from outside the immediate area starting in the late 1990s, which accounts for some of the reported decline in groundwater withdrawals since 1999 (fig. 10).

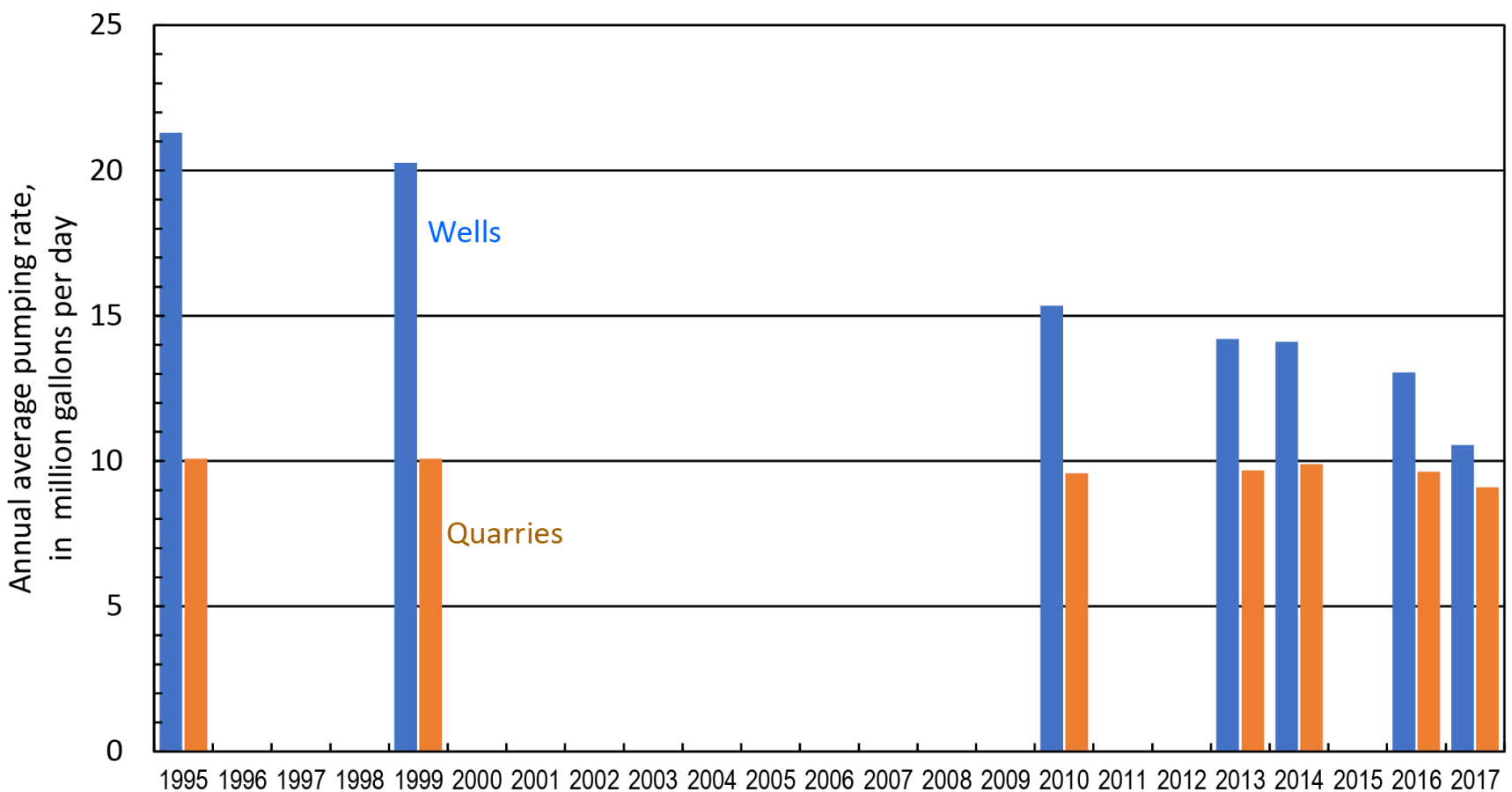

Figure 10. Total annual average reported well and quarry withdrawals in the model area near Willow Grove and Warminster, Pennsylvania, in 1995, 1999, 2010, 2013, 2014, 2016, and 2017. Data not compiled for years without plotted values. 
Table 6. Annual average withdrawals for wells and quarries in model area for selected years, 1995-2017, near Willow Grove and Warminster, Pennsylvania.

\begin{tabular}{|c|c|c|c|c|c|c|c|c|c|}
\hline \multirow[b]{2}{*}{ Year } & \multicolumn{2}{|c|}{$\begin{array}{c}\text { Annual average } \\
\text { withdrawal rate, in } \\
\text { million gallons per day }\end{array}$} & \multirow[b]{2}{*}{$\begin{array}{l}\text { Number of } \\
\text { wells }\end{array}$} & \multicolumn{6}{|c|}{ Annual average well withdrawal rate, in gallons per minute } \\
\hline & Wells ${ }^{1}$ & Quarries & & Minimum & $\begin{array}{c}\text { 10th } \\
\text { percentile }\end{array}$ & Mean & Median & $\begin{array}{c}\text { 90th } \\
\text { percentile }\end{array}$ & Maximum \\
\hline 1995 & 21.30 & 10.07 & 220 & 0.19 & 0.29 & 22.5 & 67.2 & 143.3 & $1,104.2$ \\
\hline 1999 & 20.27 & 10.07 & 244 & 0.19 & 0.30 & 13.9 & 57.7 & 130.2 & $1,104.2$ \\
\hline 2010 & 15.34 & 9.58 & 148 & 0.19 & 3.76 & 38.1 & 72.0 & 152.0 & $1,063.6$ \\
\hline 2013 & 14.21 & 9.68 & 149 & 0.05 & 2.59 & 33.2 & 66.2 & 163.6 & 618.6 \\
\hline 2014 & 14.10 & 9.89 & 149 & 0.01 & 2.39 & 25.8 & 65.7 & 148.7 & 850.7 \\
\hline 2016 & 13.05 & 9.64 & 137 & 1.00 & 3.00 & 26.0 & 66.2 & 146.2 & 983.0 \\
\hline 2017 & 10.55 & 9.10 & 133 & 0.01 & 1.60 & 12.8 & 55.1 & 127.7 & 935.3 \\
\hline
\end{tabular}

${ }^{1}$ Data for 1995 and 1999 included more wells with lower pumping rates than data for years 2010-17; Wells pumping less than 1 cubic meter per day (220 gallons per day or 0.15276 gallon per minute) were excluded from 1995 and 1999 totals and data used for model scenario for 1999 conditions. 


\section{Discharges to Streams}

Permitted discharges to streams under the NPDES in the study area include treated effluent from STPs, treated water from wells pumped for groundwater remediation, and quarry pumpage (fig. 6). Water pumped from quarries commonly is discharged to nearby streams. Data for annual discharge volumes were compiled from PADEP (2019a), from the Montgomery County Planning Commission (1994) for the year 1993, Montgomery County Planning Commission sewage treatment facilities status report (Drew Shaw, Montgomery County Planning Commission, written commun., 2019) for the year 1998, and from water-use data compiled by the USGS for 1995-98 (Solley and others, 1998; U.S. Geological Survey, 1998). Other discharges included those from groundwater remediation at NAWC Warminster and Raymark, which were estimated from groundwater withdrawals (Koman Government Solutions LLC, 2018a; U.S. Environmental Protection Agency, 2006).

Comparison of the annual average flow rates for point-source discharges to streams (table 7) to annual base-flow values (table 3 ) indicates that point-source discharges likely represent 20 percent or more of annual base flow at gage 01464907 Little Neshaminy Creek, and 40 percent or more of annual base flow at gages 01467039 Pennypack Creek at Willow Grove and 01473900 Wissahickon Creek at Fort Washington.

Table 7. Annual average discharge rates for point source discharges to streams in model area for model scenarios for 1999, 2010, 2013, 2016, and 2017 conditions near Willow Grove and Warminster, Pennsylvania. Listed rates do not include discharges from quarries. Sources of data described in Senior and others (2020). Location of discharges shown in figure 6.

\begin{tabular}{|c|c|c|c|c|c|c|}
\hline \multirow{2}{*}{ Stream receiving point-source discharge } & \multicolumn{6}{|c|}{ Annual average discharge rate } \\
\hline & 1999 & 2010 & 2013 & 2014 & 2016 & 2017 \\
\hline & \multicolumn{6}{|c|}{ Cubic feet per second } \\
\hline Little Neshaminy Creek above gage 01464907 & 1.86 & 3.11 & 3.01 & 3.16 & 3.20 & 3.20 \\
\hline Little Neshaminy Creek below gage 01464907 & 8.37 & 7.72 & 9.88 & 10.62 & 9.26 & 10.52 \\
\hline Pennypack Creek & 8.63 & 7.90 & 8.59 & 9.74 & 7.96 & 8.27 \\
\hline \multirow[t]{2}{*}{ Wissahickon Creek } & 16.61 & 15.12 & 15.74 & 16.58 & 15.98 & 15.59 \\
\hline & \multicolumn{6}{|c|}{ Millions of gallons per day } \\
\hline Little Neshaminy Creek above gage 01464907 & 1.20 & 2.01 & 1.94 & 2.04 & 2.07 & 2.07 \\
\hline Little Neshaminy Creek below gage 01464907 & 5.41 & 4.99 & 6.38 & 6.86 & 5.98 & 6.80 \\
\hline Pennypack Creek & 5.58 & 5.11 & 5.55 & 6.30 & 5.14 & 5.35 \\
\hline Wissahickon Creek & 10.73 & 9.77 & 10.17 & 10.71 & 10.33 & 10.07 \\
\hline Total of listed discharges & 22.92 & 21.87 & 24.05 & 25.91 & 23.52 & 24.29 \\
\hline
\end{tabular}




\section{Simulation of Regional Groundwater Flow}

Regional groundwater flow was simulated using a numerical model based on field measurements in the study area and on previous studies in nearby areas that have similar hydrogeologic conditions. Calibration of the model produces estimates of the large-scale hydrogeologic properties of the groundwater system and recharge rates. The model was used to characterize the average regional flow directions as affected by changes in withdrawal rates from public supply wells, and by changes in recharge. This preliminary model was made with numerous simplifying assumptions to reduce model complexity and the number of parameters, while capturing the major influence of the geology on regional groundwater-flow paths. The simulated groundwater-flow paths from possible PFAS source locations on the bases represent paths along which groundwater containing dissolved PFAS may have migrated.

\section{Conceptual Model of the Groundwater-Flow System}

The dipping Triassic sedimentary rocks form a layered, leaky aquifer system, as described in other reports (Rima and others, 1962; Senior and Goode, 1999; Goode and Senior, 2000). Below a shallow weathered zone, groundwater flow is through fractures in the rock. This fractured rock network is commonly characterized by lower storage and higher permeability than the overlying weathered rock. Directions of groundwater flow are controlled by both the hydraulic gradient and the orientation of fractures parallel and orthogonal to bedding. The structural control on groundwater flow is represented by specifying three-dimensional anisotropy in this preliminary model that parallels the strike and dip directions.

Recharge is related to geology, topography and the extent of urbanization (increased impervious area and [or] reduced permeability of soils). Base flow in selected Pennsylvania streams was shown to be related to surficial bedrock geology, with areas underlain by Triassic rocks having relatively low base flow (and inferred recharge) compared to areas underlain by carbonate rocks and some other geologic units (White and Sloto, 1990; Sloto and Buxton, 2007). Therefore, in the current groundwater model, recharge was varied spatially based on the surficial bedrock geology.

The permeability of the fractured-rock aquifers generally varies with depth, with lower permeability in soils and weathered rock than in unweathered fractured bedrock in the Triassic rocks. The depth of casing represents the thickness of weathered rock and soils, with casing typically extending about $10 \mathrm{ft}$ into competent bedrock. The median and mean casing length reported for pumping wells is about $50 \mathrm{ft}$ (table 4). Water-producing fractures in the Stockton and Lockatong Formations are most commonly reported at depths of $400 \mathrm{ft}$ or less (Low and others, 2002; Bird, 1998), but water-bearing zones are reported at depths of $500 \mathrm{ft}$ or more. In the conceptual model for this study, water-bearing properties of the unweathered bedrock decrease with depth below $400 \mathrm{ft}$.

The groundwater flow system in the study area is relatively local, with groundwater divides generally near surface-water divides except in areas affected by pumping or in carbonate rock settings. Most groundwater discharge is to nearby streams, based on water-table mapping and streamflow seepage data. The study area boundaries were established at remote watershed divides and beneath remote major streams. 


\section{Model Approach and Methods}

The three-dimensional numerical model, MODFLOW 6 (Langevin and others, 2017, 2018; Provost and others, 2017) was used to simulate steady-state flow for several time periods with different recharge rates and well withdrawals. Model input files were produced using ArcGIS for Desktop 10.7 (Esri, 2019) and ModelMuse version 4 (Winston, 2019), a graphical pre- and post-processor for groundwater modeling. PEST++ (Welter and others, 2015, White and others, 2019), which is based on the methods and algorithms of PEST (Doherty, 2015), was used for model calibration. The Python script for PEST++ calibration of the model using FloPy (Bakker and others, 2016, 2018) is provided in the model archive data release (Goode and Senior, 2020), along with all MODFLOW 6 input and output files. MODPATH 7 (Pollock, 2016, 2017) was used to compute flow paths (particle tracks or pathlines).

Features, assumptions, and approximations in the regional groundwater-flow model included

- flow conditions in each simulation were approximated as steady state, which represent annual average conditions for the associated time period;

- all model layers were assumed to be confined or semi-confined in that the horizontal transmissivity did not depend on water level;

- recharge and hydraulic conductivity were uniform within zones defined by the regional geology; and

- flow within the fractured-rock aquifers was simulated as bulk flow distributed throughout the model cells, based on the equivalent porous media approximation.

\section{Model Area and Spatial Discretization}

The horizontal boundaries of the model area (fig. 1) were assumed to be no-flow boundaries. Several of the boundary segments were located to include regional streams around the Willow Grove and Warminster bases, based on the assumption that groundwater flow beyond these streams does not substantially influence flow paths near the bases. Additional no-flow horizontal boundaries were located along ridges (surface-drainage watershed boundaries) and geologic boundaries associated with low-permeability formations. These no-flow boundaries were specified to include all local streams and wells that were considered to potentially affect flow paths near the bases.

The discretization by vertices (DISV) grid type with quad-tree refinement of MODFLOW 6 was selected to allow higher grid resolution near the bases and near wells, streams, and diabase dikes, while reducing the numerical computational burden in other parts of the model domain (figs. 11 and 12). The model coordinate system is in units of meters (m), and input data are in units of meters and days, for example cubic meters per day for withdrawal rates. The largest cells are 1,640 by $1,640 \mathrm{ft}(500$ by $500 \mathrm{~m})$ and the smallest are 205 by $205 \mathrm{ft}$ (62.5 by $62.5 \mathrm{~m}$ ). The DISV quad-tree refined grid type is compatible with ModelMuse 4 and MODPATH 7, the latter with the additional restriction that the grid not be rotated with respect to the coordinate system (Pollock, 2016). The horizontal grid configuration is the same for all layers of the model, which is a restriction for the DISV grid type. 


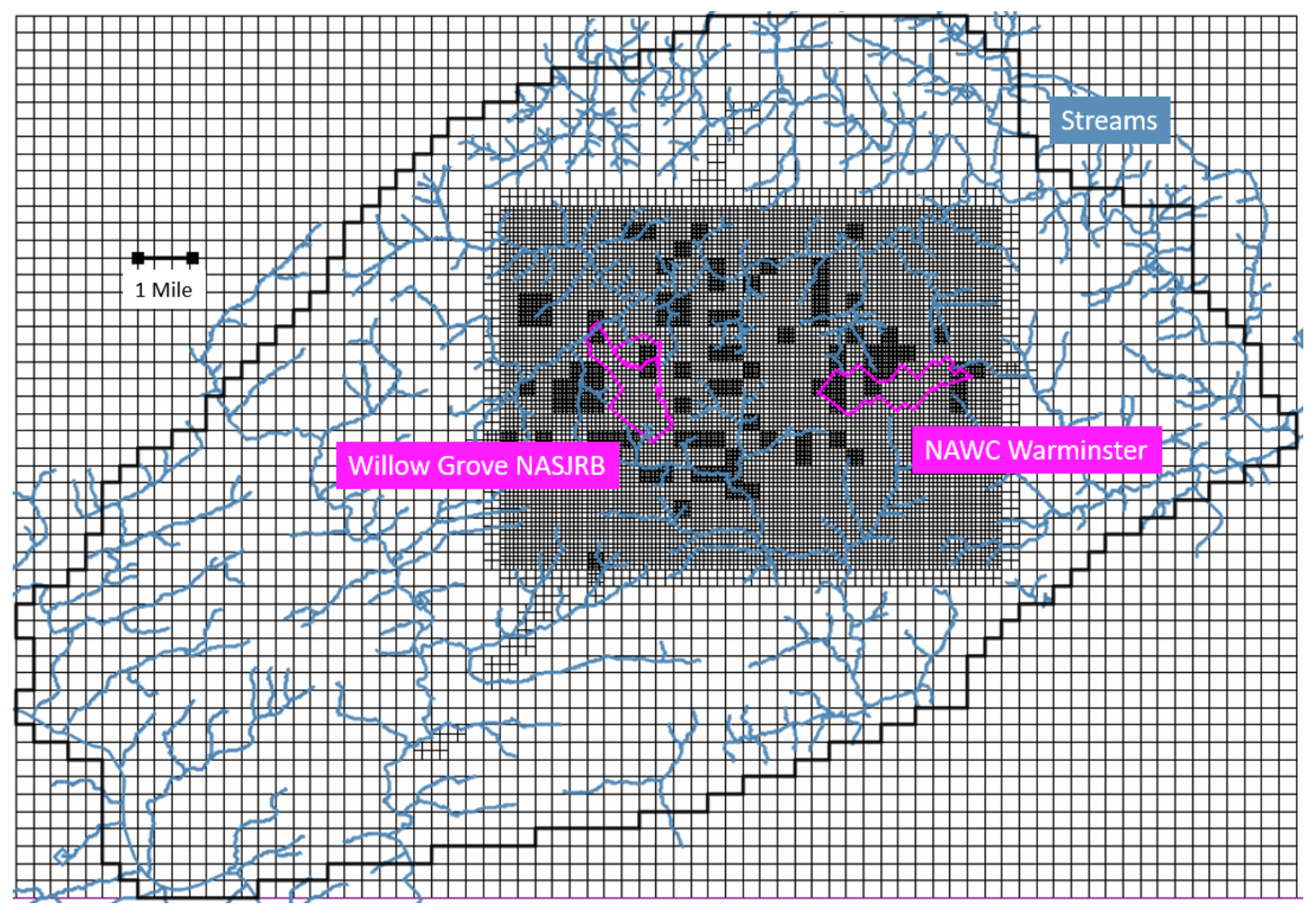

Figure 11. ModelMuse screenshot of full model grid with model streams near Willow Grove and Warminster, Pennsylvania. 


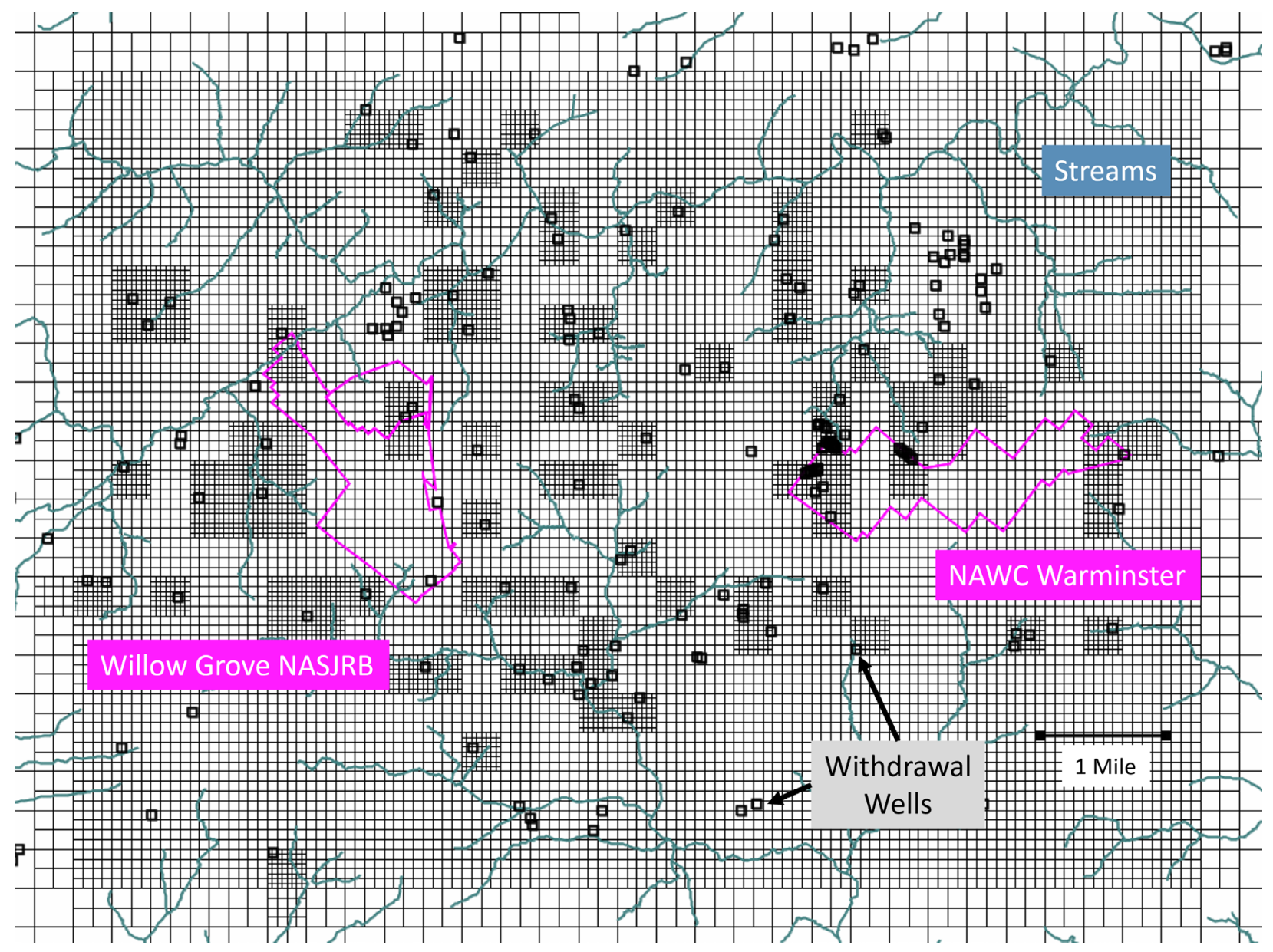

Figure 12. ModelMuse screenshot of detail of model grid cells and withdrawal well locations close to the bases near Willow Grove and Warminster, Pennsylvania.

The altitude of the top of the model was interpolated to the grid cell nodes from the 3-m digital elevation model (DEM; Penn State Institutes of Energy and Environment, 2015). Seven model layers were used, each with uniform thickness (table 8, fig. 13). Layer thickness increases with depth, and the overall model thickness is about $800 \mathrm{ft}(244 \mathrm{~m})$. The top two layers represent overburden and weathered rock and are homogeneous. Layers 3-7 represent the unweathered fractured rock aquifer, in which properties were specified according to the geologic unit. The lower surface of the bottom model layer is a no-flow boundary. 


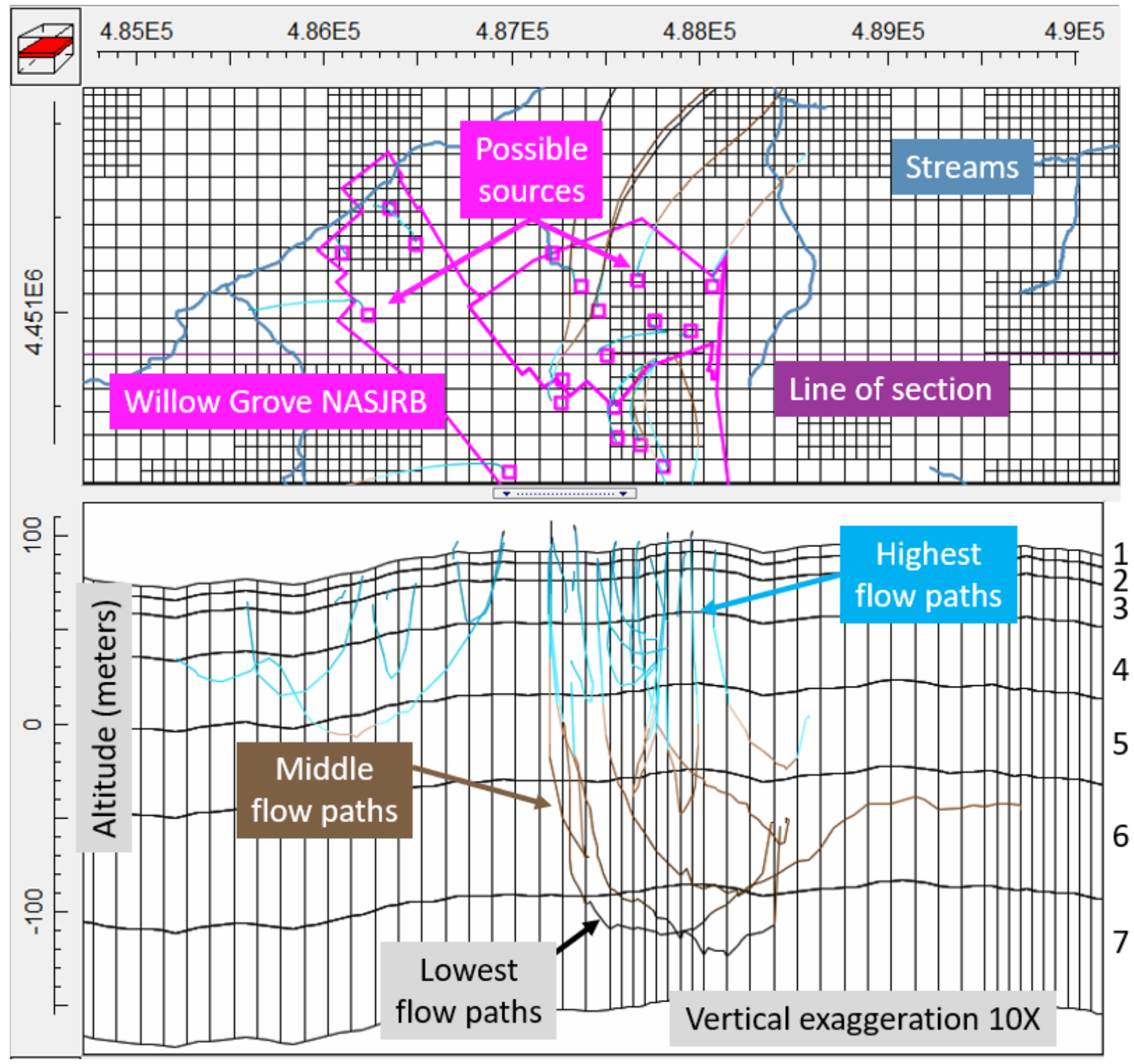

Figure 13. ModelMuse screenshot of details near Willow Grove of model grid in plan (top) and cross section (bottom) showing seven model layers with illustrative regional groundwater-flow paths from possible sources to discharge cells. The color of the pathlines change with altitude from blue (highest) to brown (middle) to black (lowest). 
Table 8. Model layer thicknesses and hydraulic conductivity variation with depth

[K, hydraulic conductivity; Kmax, parameter for $\mathrm{Kx}$ in strike direction by hydrogeologic zone; $\mathrm{m}$, meters; $\mathrm{ft}$, feet]

\begin{tabular}{clccccc}
\hline $\begin{array}{c}\text { Model } \\
\text { layer }\end{array}$ & Name & $\begin{array}{c}\text { Thickness } \\
(\mathbf{m})\end{array}$ & $\begin{array}{c}\text { Bottom depth } \\
(\mathbf{m})\end{array}$ & $\begin{array}{c}\text { Thickness } \\
(\mathbf{f t})\end{array}$ & $\begin{array}{c}\text { Bottom depth } \\
(\mathrm{ft})\end{array}$ & $\begin{array}{c}\text { K scaling with } \\
\text { depth }\end{array}$ \\
\hline \multicolumn{7}{c}{ Homogeneous overburden and weathered rock } \\
\hline 1 & Soil & 6.1 & 6.1 & 20 & 20 & Same K as layer 2 \\
2 & Weathered & 9.1 & 15.2 & 30 & 50 & Same K as layer 1 \\
\hline \multicolumn{7}{c}{ Unweathered rock, properties by hydrogeologic zone } \\
\hline 3 & Shallow & 22.9 & 38.1 & 75 & 125 & $\mathrm{~K}=\mathrm{Kmax} / 2$ \\
4 & Transition & 38.1 & 76.2 & 125 & 250 & $\mathrm{~K}=\mathrm{Kmax}$ \\
5 & Intermediate & 45.7 & 121.9 & 150 & 400 & $\mathrm{~K}=\mathrm{Kmax}$ \\
6 & Deep & 61.0 & 182.9 & 200 & 600 & $\mathrm{~K}=\mathrm{Kmax} / 2$ \\
7 & Basement & 61.0 & 243.9 & 200 & 800 & $\mathrm{~K}=\mathrm{Kmax} / 20$ \\
\hline
\end{tabular}




\section{Model Hydrogeologic Zones}

The model hydrogeologic properties and recharge rates are zoned according to the surficial bedrock geology. The Stockton Formation, which underlies most of the model area and the Willow Grove NASJRB and NAWC Warminster, is separated into upper, middle, and lower members in Montgomery County (Rima and others, 1962; Lyttle and Epstein, 1987). The members have different hydrogeologic characteristics; notably, the finer grained upper member is generally observed to yield less water than the middle and lower members (Rima and other, 1962). In order to approximately account for this hydrogeologic variability, a hypothetical hydrogeologic contact between the upper and middle members is assumed in the model area in Bucks County (fig. 14). The location of the actual contact is unknown. For the model, the offset of the upper/middle contact from the contact between the Stockton and Lockatong Formations in Bucks County is conceptually extrapolated from its configuration in Montgomery County, and with the mapped diabase dike configuration. A hypothetical contact was also added in Bucks County between the middle and lower members of the Stockton Formation, but the hydrogeologic properties of the model are the same in these members, designated as the "middle and lower Stockton zone." These hypothetical contacts in Bucks County are solely for the purpose of assigning hydrogeologic zones for this model.

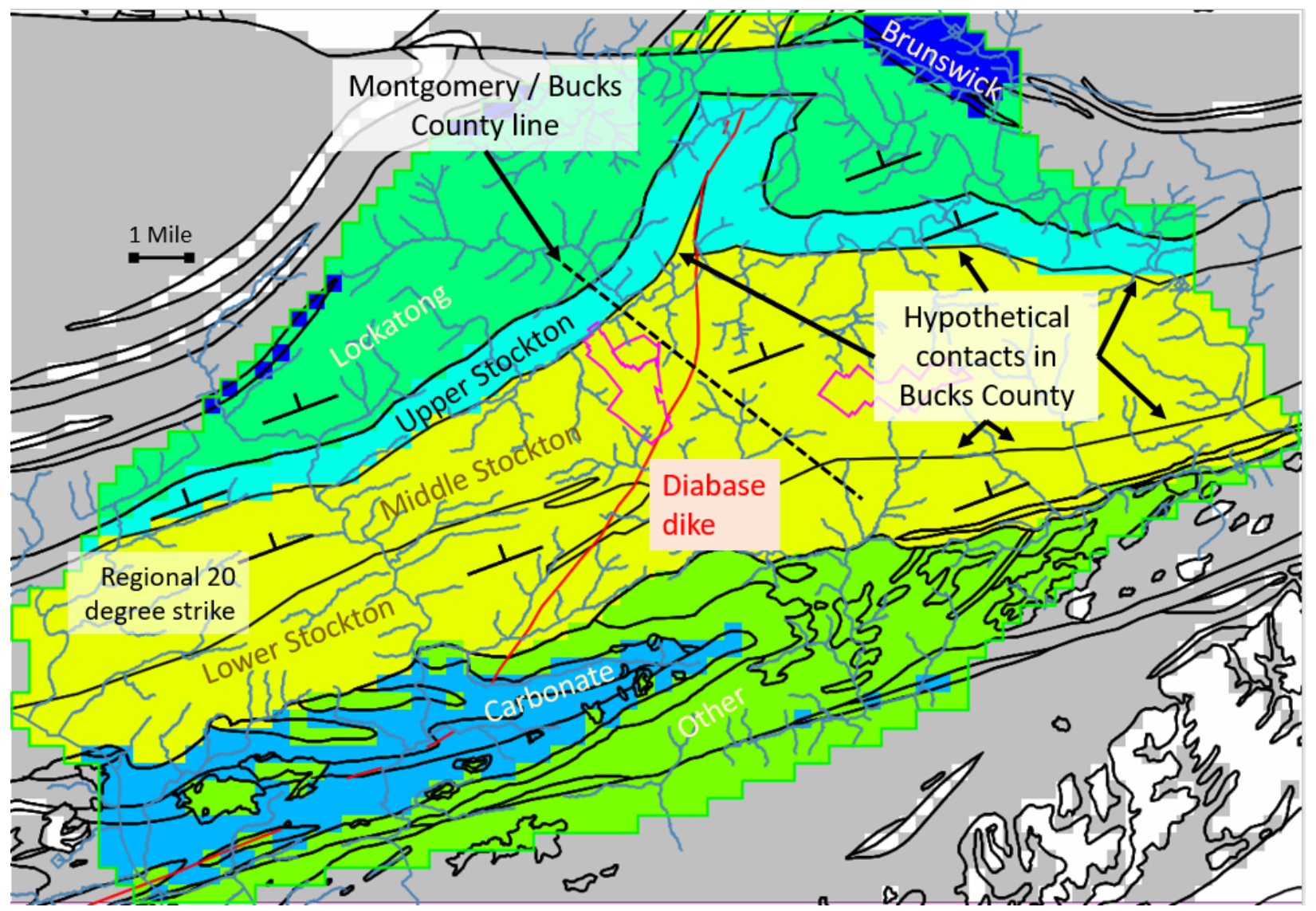

Figure 14. ModelMuse screenshot of model hydrogeologic zones: Upper Stockton, Middle and Lower Stockton, Lockatong, Brunswick, Carbonate, and Other. Hypothetical contacts between the upper and middle members and between the middle and lower members of the Stockton Formation were added in the Bucks County portion of the model. Bases shown in magenta outline. 


\section{Aquifer Inflows and Outflows}

The principal inflows to the aquifer consist of local recharge from infiltration of precipitation and stream loss, and the principal outflows from the aquifer consists of discharges to wells and quarries (as withdrawals), and to streams (as base flow). Other processes, such as evapotranspiration, were not explicitly considered.

\section{Recharge}

Groundwater recharge from the land surface and unsaturated zone was simulated into the top layer (1) of the model. Recharge was zoned with the surface-mapped geology, based on findings from previous studies in the vicinity (White and Sloto, 1990; Schreffler, 1996; Sloto and Buxton, 2007) and the relative rates of recharge for each geologic unit were fixed based on those studies (fig. 15, appendix 2, table 2.1). For this preliminary model, a single scale factor parameter was used to adjust the initial recharge rates proportionally for the entire model domain for all time periods.

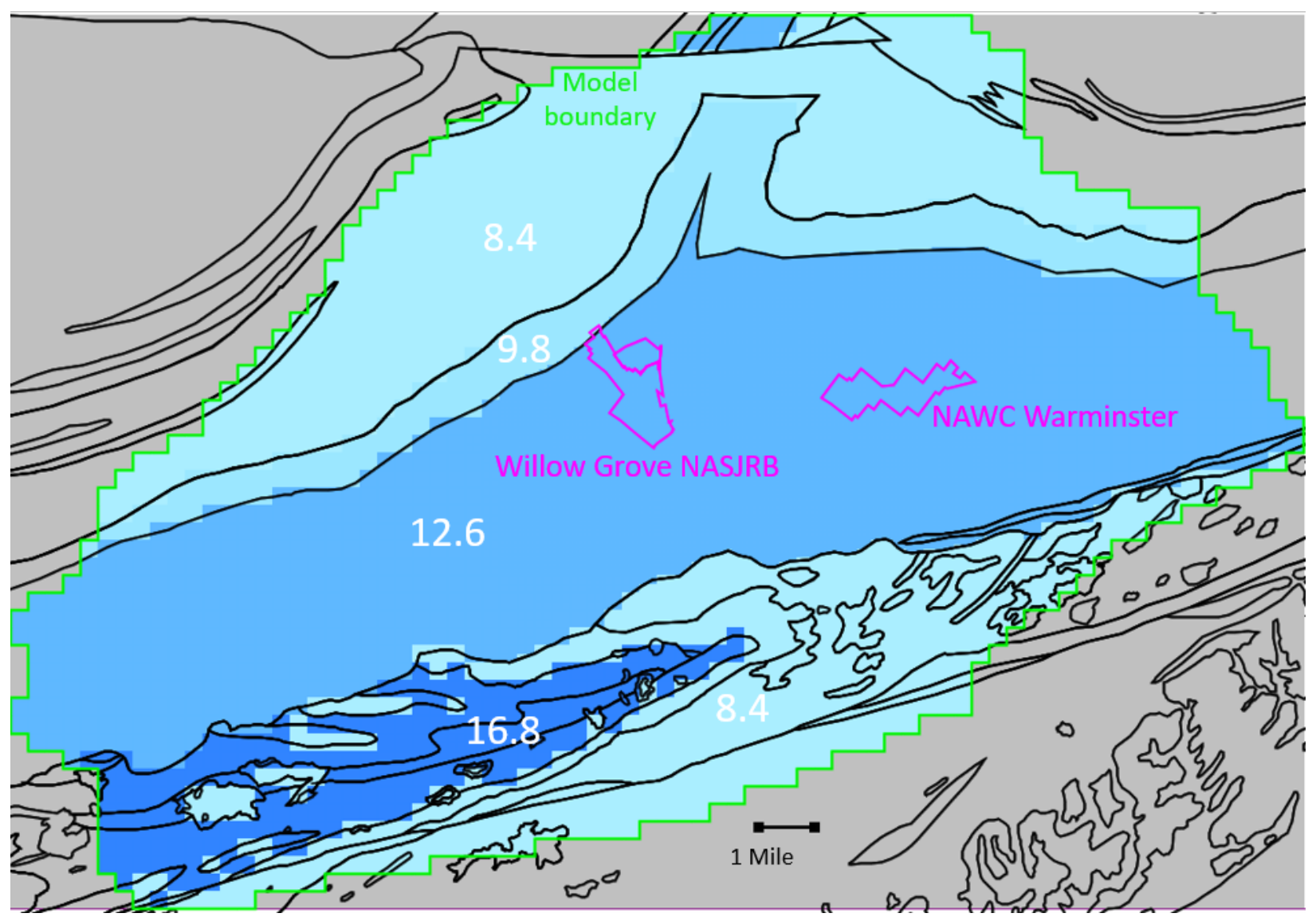

Figure 15. ModelMuse screenshot of model recharge rates in 2010 and 2013 in inches per year, zoned by geologic unit. Recharge rates for other periods were reduced to 90 percent of the values shown for 1999 and 70 percent for 2016 and 2017. 


\section{Groundwater Withdrawals}

Senior and others (2020) compiled groundwater withdrawal data and developed modelinput tables for use with the MODFLOW 6 WEL package. Groundwater withdrawal wells were assigned to the model layer corresponding to the mid-point of the open interval of the well.

Wells for which the mid-point is below the model bottom were assigned to the bottom (7) model layer.

The overall magnitude of the groundwater withdrawals used in the model are illustrated for 1999 (fig. 16) and 2017 (fig. 17) conditions using the well-withdrawal footprint visualization method of Goode (2016) as implemented in ModelMuse (Winston and Goode, 2017). The withdrawal rate for each well is shown as a circular area centered on the well, and the area of the circle is proportional to the withdrawal rate. For closely spaced wells, a merged shape (footprint) is drawn that has the area corresponding to the combined withdrawals for all wells within that merged shape, based on a scale factor, the depth-rate-index (Goode, 2016). In this example, the scale factor is 10 inches per year (in/year) (0.25 meters per year [m/year]), comparable to the average recharge rate for the calibrated model.

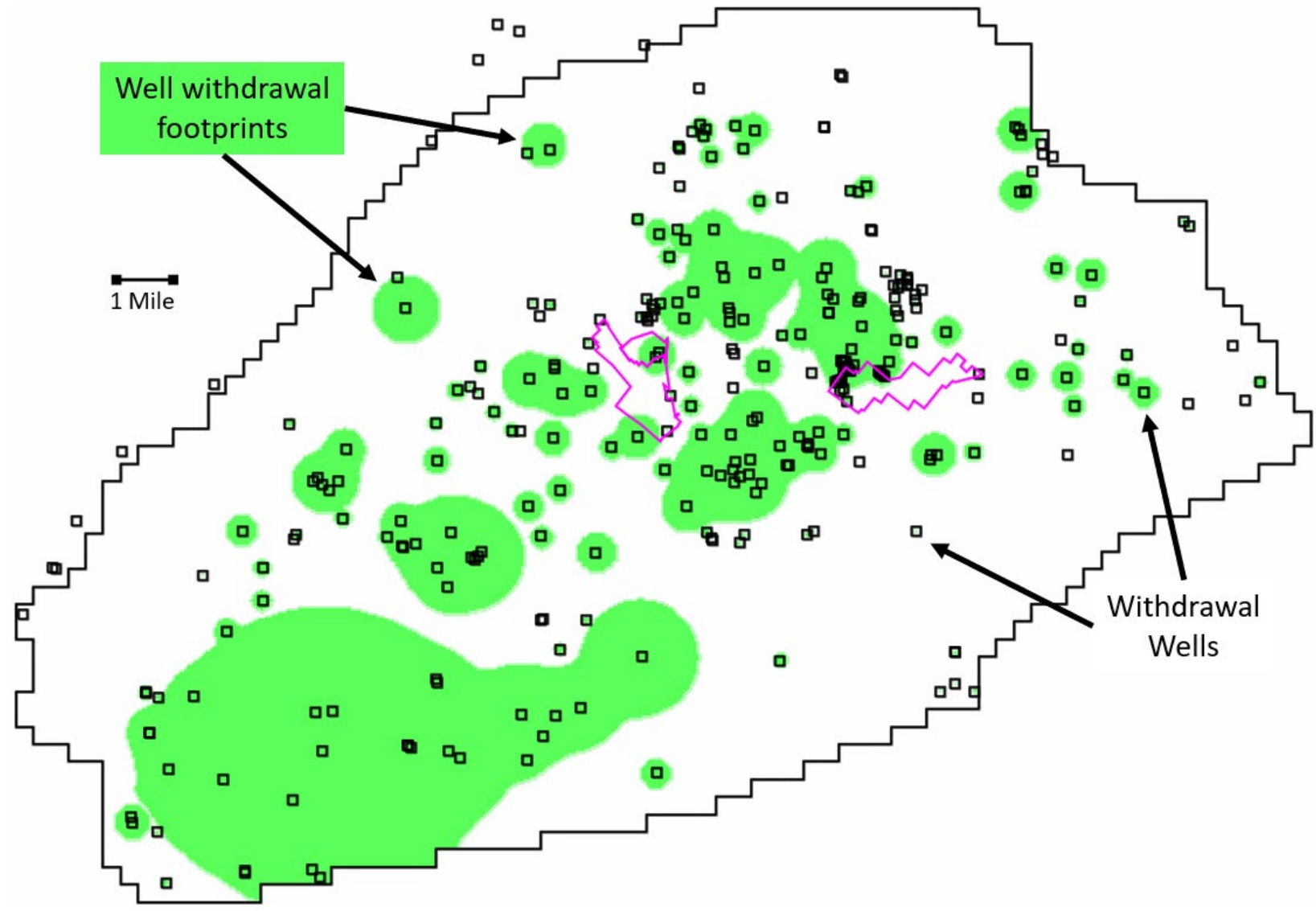

Figure 16. ModelMuse screenshot of model groundwater withdrawal rates visualized as well-withdrawal footprints (method of Winston and Goode, 2017) for simulation of conditions in 1999. The footprint depthrate-index (scale) is 10 inches per year. Bases shown in magenta outline. 


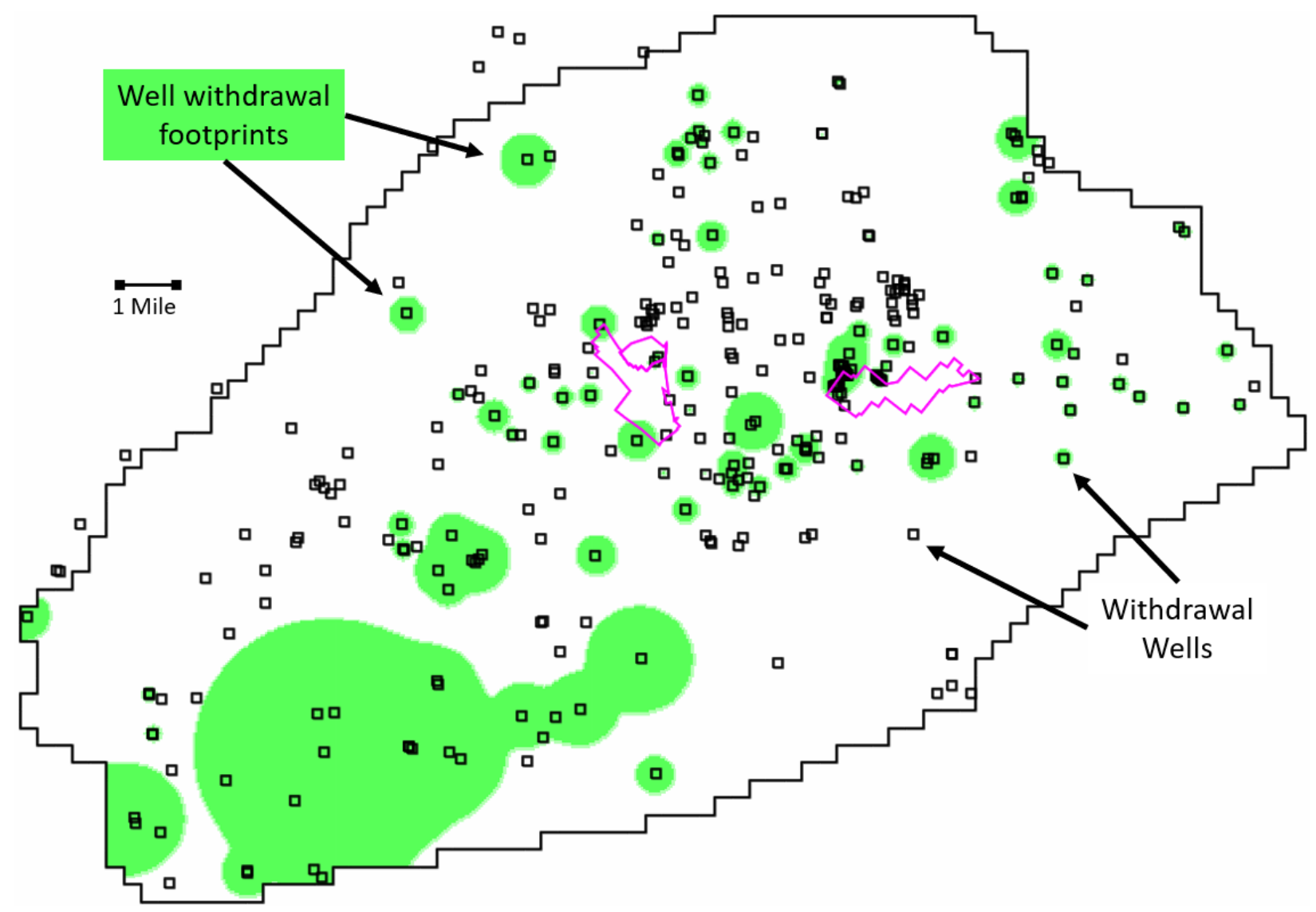

Figure 17. ModelMuse screenshot of model groundwater withdrawal rates visualized as well-withdrawal footprints (method of Winston and Goode, 2017) for simulation of conditions in 2017. The footprint depthrate-index (scale) is 10 inches per year. Bases shown in magenta outline. 
Increases in withdrawals from wells change groundwater levels and groundwater-flow paths, diverting paths from streams or other wells towards or into the pumped well. Past changes in pumping have thus changed past flow paths. As discussed previously, pumping near the Willow Grove and Warminster bases has generally declined from the 1990s until the present, as illustrated by the difference between the well-withdrawal footprints from 1999 to 2017 (fig. 18), and these changes in the model will change the simulated flow paths.

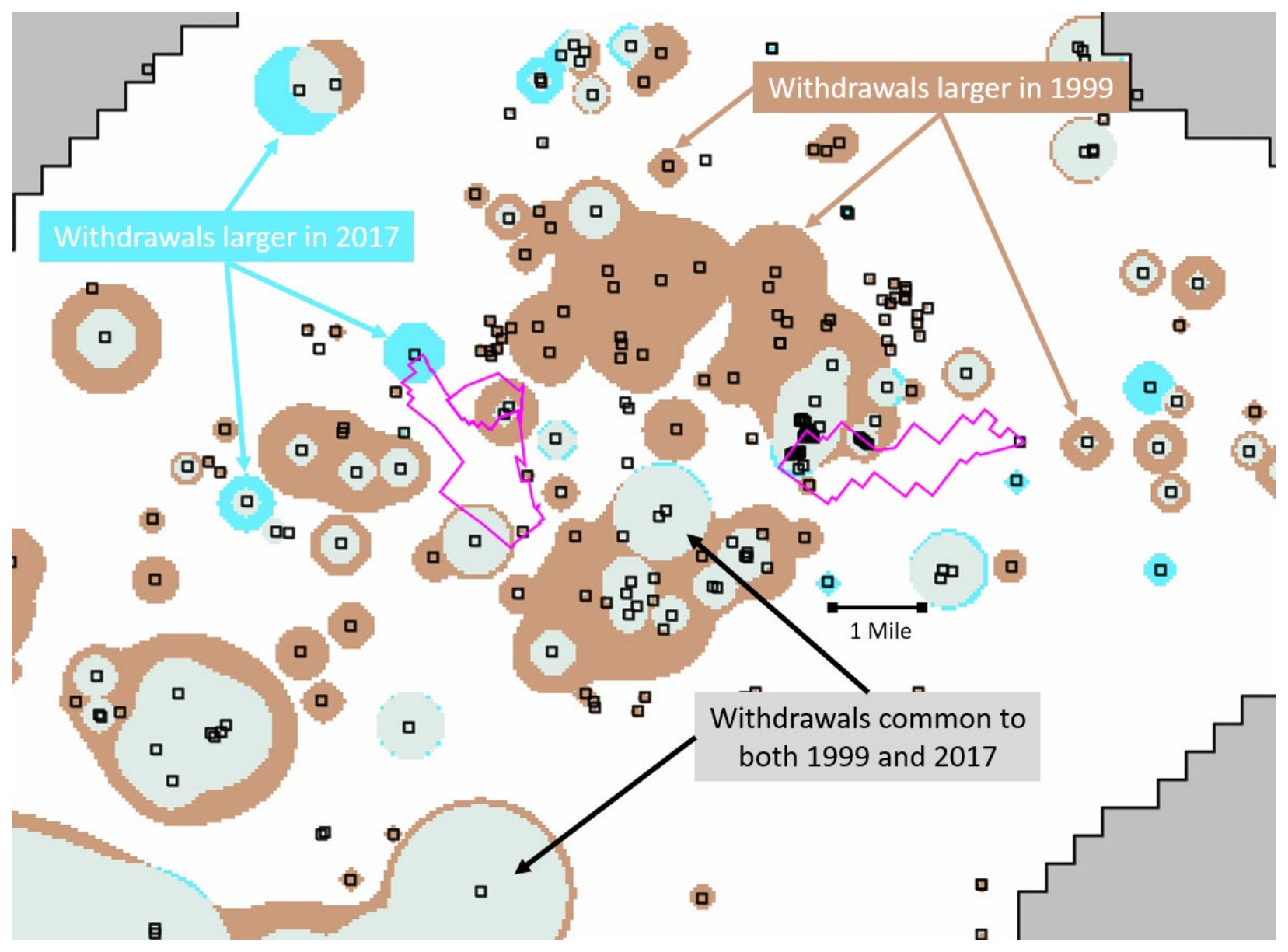

Figure 18. ModelMuse screenshot of changes in groundwater withdrawal rates in the Willow Grove and Warminster area visualized by the difference between well-withdrawal footprints (method of Winston and Goode, 2017) for 1999 (fig. 16) and 2017 (fig. 17). Light gray area shows volumetric rate of withdrawals common to both years. Brown area shows decrease in volumetric rate from 1999 to 2017. Blue area shows increase in volumetric rate from 1999 to 2017. The footprint depth-rate-index (scale) is 10 inches per year. Bases shown in magenta outline, and wells as black squares. 


\section{Flow to and from Streams}

Streams draining the study area include Park Creek, Little Neshaminy Creek, Neshaminy Creek, Pennypack Creek, Wissahickon Creek, Mill Creek, and their tributaries (fig. 1). The Schuylkill River drains the west edge of the model area. A stream network was developed for model input from the National Hydrography Dataset (U.S. Geological Survey, 2016) augmented with selected tributary streams (fig. 1) from datasets provided by Robert H. Keough (Bucks County Planning Commission, written commun., 2016), and William McLay (Montgomery County Planning Commission, written commun., 2016).

Streamflow data collected at seven USGS stream gages were used to provide information about groundwater discharge; these gages included one on Little Neshaminy Creek (01464907 at Valley Road), four on Pennypack Creek (01467031 at Horsham, 01467036 at Hatboro, 01467039 at Willow Grove, and 014670413 at Bethayres), one site on a tributary to Mill Creek (01465460 Iron Works Creek at Richboro), and one site on Wissahickon Creek (01473900 at Fort Washington) (table 2; figs. 3 and 6).

As discussed in the Streamflow section, the base-flow component of streamflow reflects the amount of groundwater discharge to streams and can be used to estimate recharge to groundwater. Measured flow at the streams in the study area could also include upstream point discharges to those streams from STPs, quarries, or other activities. Streamflow data used to calculate base flow from groundwater were not adjusted for these point discharges; therefore, the estimated base flow could be overestimated. These point discharges are specified as inflows to the model, however, so that simulated flow at stream gage locations includes contributions of both base flow from groundwater and upstream point discharges.

The MODFLOW 6 Streamflow Routing (SFR) package was selected to represent the stream network because it accumulates flow from upstream reaches to downstream reaches, permitting the use of streamflow observations in model calibration, and because it limits stream loss (flow from the stream into the aquifer) to the amount of flow available in the simulated reach. Stream stages were specified in each reach using the 3-m DEM for simplicity and numerical stability, rather than computing for the stream stages from a hydraulic equation. Specified stream stages increase in the downstream direction in some simulated reaches as a result of the coarse model resolution and the approximate interpolation from the DEM, but this inconsistency does not substantially affect simulated regional groundwater levels and flow paths. However, the simulated groundwater-stream interactions in and near these model cells may not be representative of field conditions.

Point discharges to streams (fig. 6) are represented as SFR reaches with specified INFLOW to that reach, which corresponds to the annual average volumetric discharge (in cubic meters per day $\left.\left[\mathrm{m}^{3} / \mathrm{d}\right]\right)$. A very small streambed conductance was specified in each reach with a point discharge (fig. 19) to minimize flow to or from the aquifer and to route the point discharge flow to the downstream reach. 


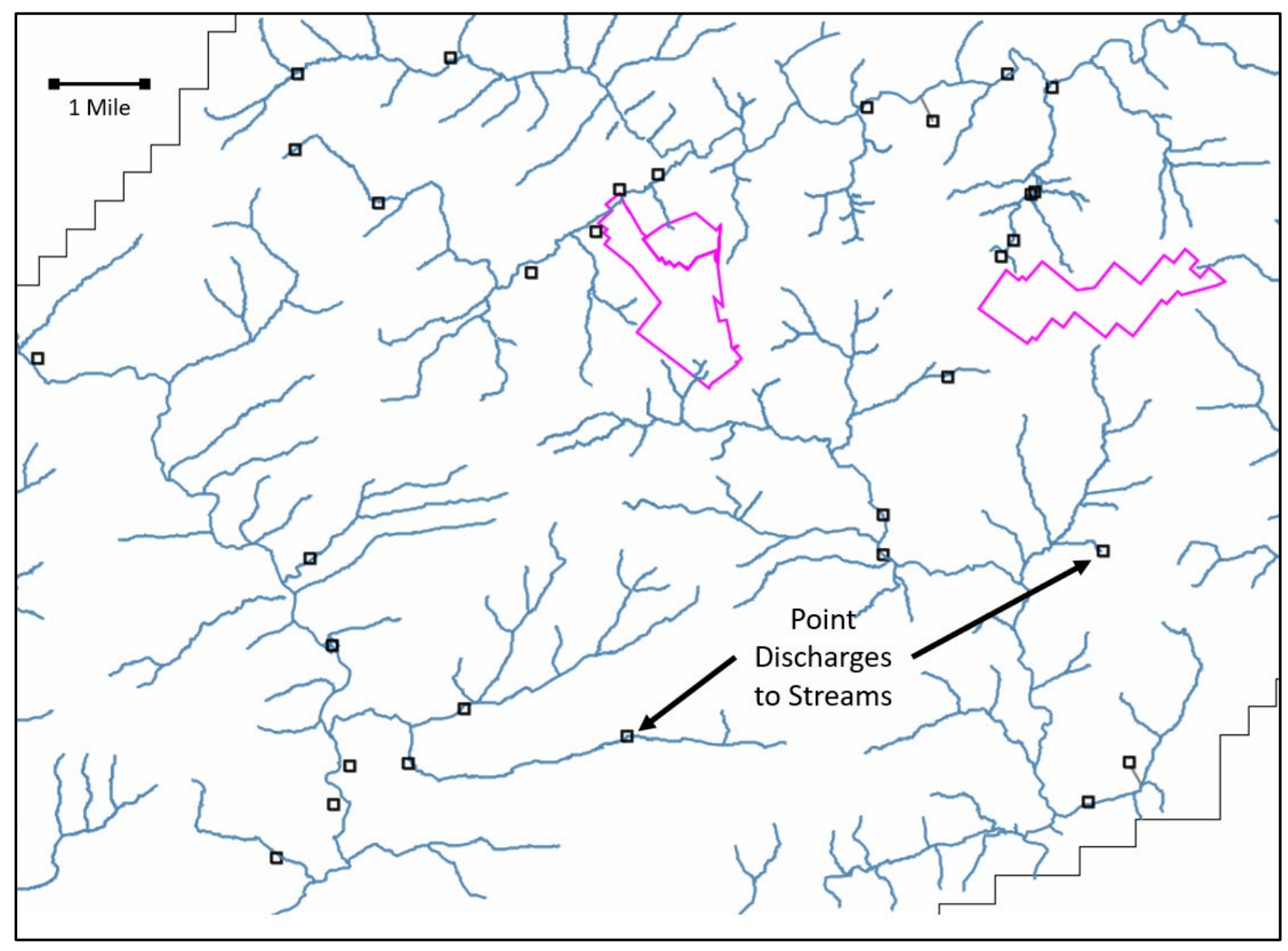

Figure 19. ModelMuse screenshot of locations of model point discharges to streams. Bases shown in magenta outline. 


\section{Bulk Hydraulic Conductivity and Anisotropy}

The regional anisotropy in hydraulic conductivity $(\mathrm{K})$ reflects the preferential groundwater flow along the strike of dipping beds, and reduced flow in the dip direction and perpendicular to those beds. Hydraulic conductivity was specified through a three-dimensional tensor. The maximum hydraulic conductivity $(\mathrm{Kx})$ is oriented in strike. The medium hydraulic conductivity $(\mathrm{Ky})$ is oriented perpendicular to $\mathrm{Kx}$ in the plane of the bedding, and is a proportion of $\mathrm{Kx}$, ranging from $1 / 10$ to 1 , referred to as horizontal anisotropy. The minimum hydraulic conductivity $(\mathrm{Kz})$ is oriented orthogonal to the plane of $\mathrm{Kx}$ and $\mathrm{Ky}$, or perpendicular to the bedding, and is a proportion of $\mathrm{Kx}$ ranging from $1 / 10$ to 1 , referred to as vertical anisotropy.

Anisotropy in model layers 3-7, which represent unweathered fractured rock, was specified such that $\mathrm{Kx}$, was rotated 20 degrees north from east-west, (Winston, 2019, fig. 7). The dip angle for Ky is variable, with a northwest down dip of 13 degrees specified in the Stockton Formation and 10 degrees in the Lockatong Formation and the Brunswick Group (fig. 20 ) to reflect the measured orientation of sedimentary rock beds (Greenman, 1955; Rima and others, 1962; Longwill and Wood, 1965).

The Carbonate and Other zones are assumed to be isotropic in the plane of the layer $(\mathrm{Kx}$ $=\mathrm{Ky})$ and to have a dip angle of zero and a vertical anisotropy $(\mathrm{Kz} / \mathrm{Kx})$ of $1 / 3$.

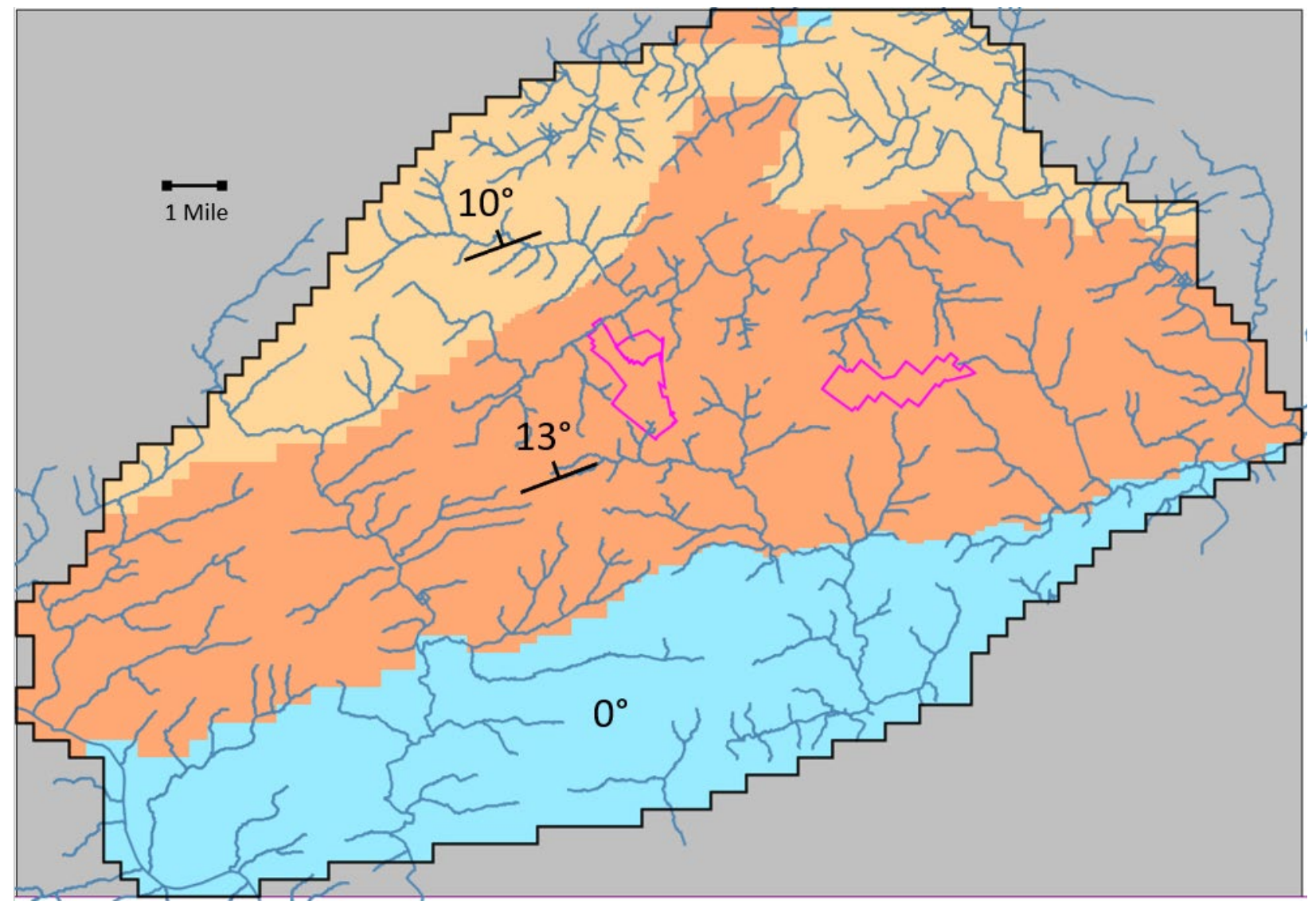

Figure 20. ModelMuse screenshot showing model down dip angles to the northwest for hydraulic conductivity tensor in model layers 3 to 7 , which represent unweathered fractured rock. Bases shown in magenta outline. 


\section{Model Calibration}

Initial model simulations were conducted using starting values for aquifer properties and boundary conditions based on previous model studies in the Stockton Formation and nearby studies (Senior and Goode, 1999, 2013, 2017). Manual adjustments were made to qualitatively match the simulated water levels to available water-table maps, especially at Willow Grove (Sloto and others, 2001) and Warminster (Tetra Tech, written commun., 2019).

Several model properties were selected for automatic calibration through nonlinear regression using PEST++ (White and others, 2019), including

- bulk aquifer hydraulic conductivity values (K), including anisotropy values;

- recharge rate scale for four time periods; and

- streambed conductance value for all model streams.

A subset of the model $\mathrm{K}$ values was selected for automatic calibration, based in part on sensitivities calculated with PEST ++ , and based in part on the conceptual model, hydrogeologic judgement based on previous studies, and field testing (appendix 2, table 2.2). Some K values, such as Kz, oriented orthogonal to dipping beds, were adjusted proportionally during calibration to the $\mathrm{Kx}$ value for that zone, and thus the anisotropy ratio is fixed. Other values, such as all $\mathrm{K}$ values for the "Other" zone (fig. 14), were fixed at initial manually adjusted values. The orientation of the K anisotropy tensor (Provost and others, 2017; Winston, 2019) was specified based on field measurements of geologic strata strike and dip and was not adjusted during calibration (fig. 20).

The recharge rates for all four calibration time periods, 1999, 2010, 2013, and 2016, were adjusted proportionally to a single model parameter, RECH. Based on annual stream base-flow analysis, and initial manual model adjustments, recharge values were $0.9 \mathrm{x}$ RECH for $1999,1.0 \mathrm{x}$ RECH for 2010 and 2013, and 0.7 x RECH for 2017. Recharge values varied spatially by four hydrogeologic zones and were scaled proportionally to the single recharge parameter (fig. 15).

To calibrate the model, 1,009 groundwater-level measurements in 670 wells were used (fig. 8; table 4). Groundwater levels in 1999 are from measurements taken in early October 1999 for a synoptic water-level map (Sloto and others, 2001) and other measurements in the 1990s included in the USGS National Water Information System (NWIS) database. Well construction information is limited for many of these wells. Measurements were assigned to specific model layers based on the mid-point of the open interval of the well. Average values of casing depth and total well depth were used to determine the appropriate model layer with missing construction data. More recent data in 2010, 2013, and 2016 are compiled from various sources including the USGS NWIS database and monitoring wells on and near the former bases. Streamflow data for calibration were taken from estimates of annual base flow at seven USGS stream gages in the study area (table 9).

All water-level data were assigned a uniform weight of 1.0. The weight for all streamflow data was 0.003 to account for the difference in the units of the streamflow data, $\mathrm{m}^{3} / \mathrm{d}$ compared to the water levels $(\mathrm{m})$, and to ensure that the streamflow data contributed substantially to the calibration objective function in the regression (Doherty and Hunt, 2010). The stream flow model error was about 14 percent of the total model error for the final calibration. 
Table 9. Streamflow measurements used for model calibration.

[--, not available]

\begin{tabular}{|c|c|c|c|c|c|c|}
\hline \multirow{2}{*}{ Site number } & \multirow{2}{*}{ Site name (all in Pennsylvania) } & \multirow{2}{*}{ Short name } & \multicolumn{4}{|c|}{ Streamflow, in cubic meters per day } \\
\hline & & & 1999 & 2010 & 2013 & 2016 \\
\hline 01464907 & Little Neshaminy Creek at Valley Road near Neshaminy & LilNeshV & 26,790 & 38,998 & 41,885 & 37,041 \\
\hline 01465460 & Iron Works Creek at Richboro & IronWorks & -- & 5,480 & 4,746 & -- \\
\hline 01467031 & Pennypack Creek at Horsham & PennyHor & -- & 6,141 & 5,774 & -- \\
\hline 01467036 & Pennypack Creek at Hatboro & PennyHat & -- & 5,725 & 4,771 & -- \\
\hline 01467039 & Pennypack Creek near Willow Grove & PennyWG & -- & 59,232 & 53,164 & -- \\
\hline 014670413 & Pennypack Creek at Bethayres & PennyBeth & -- & 91,844 & 81,985 & -- \\
\hline 01473900 & Wissahickon Creek at Fort Washington & WissFtWash & -- & 92,529 & 95,001 & 66,620 \\
\hline
\end{tabular}


The calibrated model is deemed adequate for simulation of regional groundwater flow and flow paths. Summary graphs of the simulated and measured water levels and base flow used for model calibration are presented in this section. More detailed results of the final calibration are presented in appendix 2, including the spatial distribution of water-level residuals for the four calibration periods.

The overall fit between the simulated and measured water levels for the four time periods used for calibration is shown in figure 21. The histogram of all water-level residuals (fig. 22) shows a relatively narrow concentration of residuals around zero, with about 75 percent of residuals smaller than plus or minus $16.4 \mathrm{ft}(5 \mathrm{~m})$. The mean residual is $-0.79 \mathrm{ft}(-0.24 \mathrm{~m})$, and the root mean square residual is $0.6 \mathrm{ft}(0.18 \mathrm{~m})$.

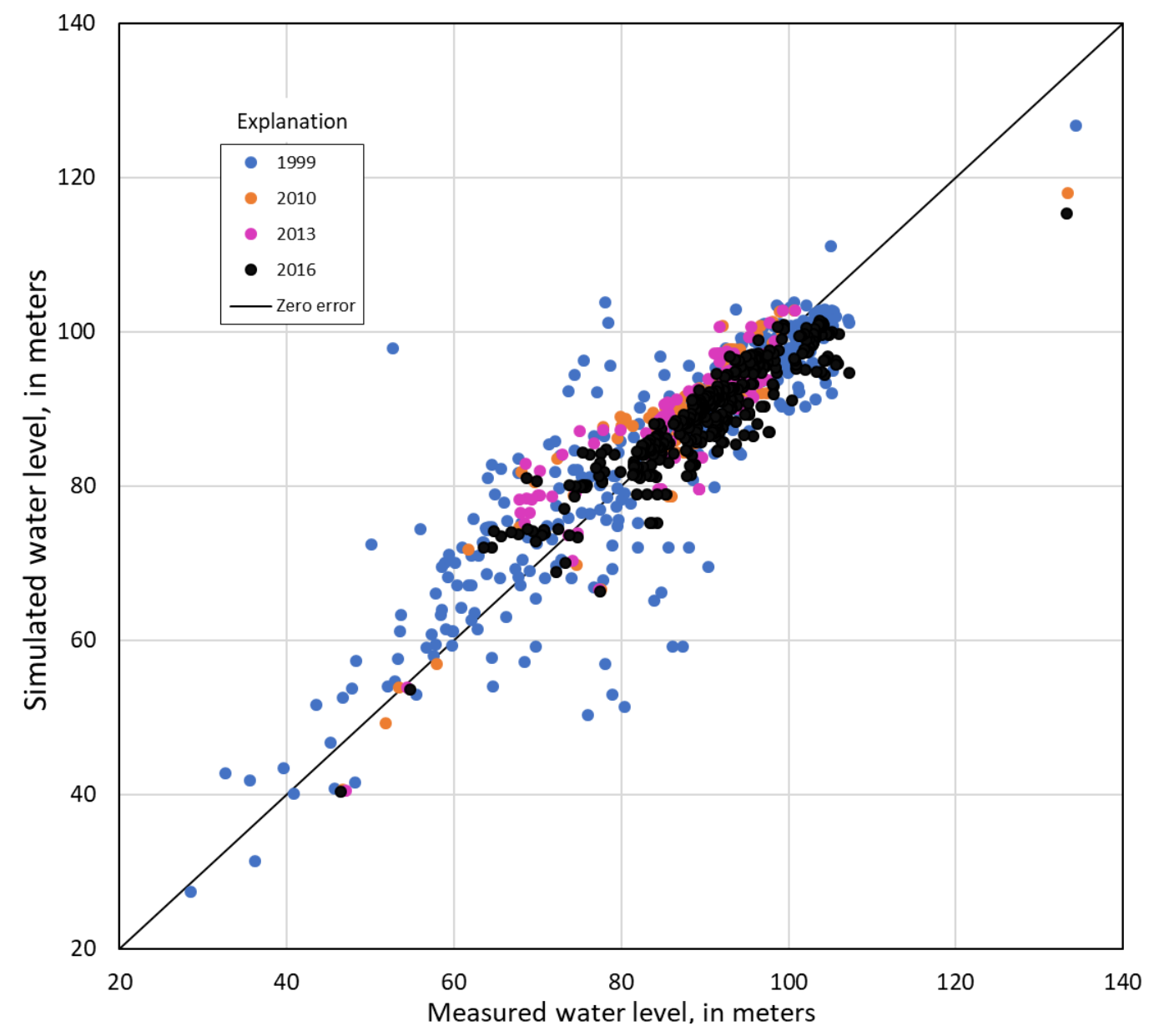

Figure 21. Simulated and measured water levels in wells for optimum parameters identified by calibration for each model period, 1999, 2010, 2013, and 2016. 


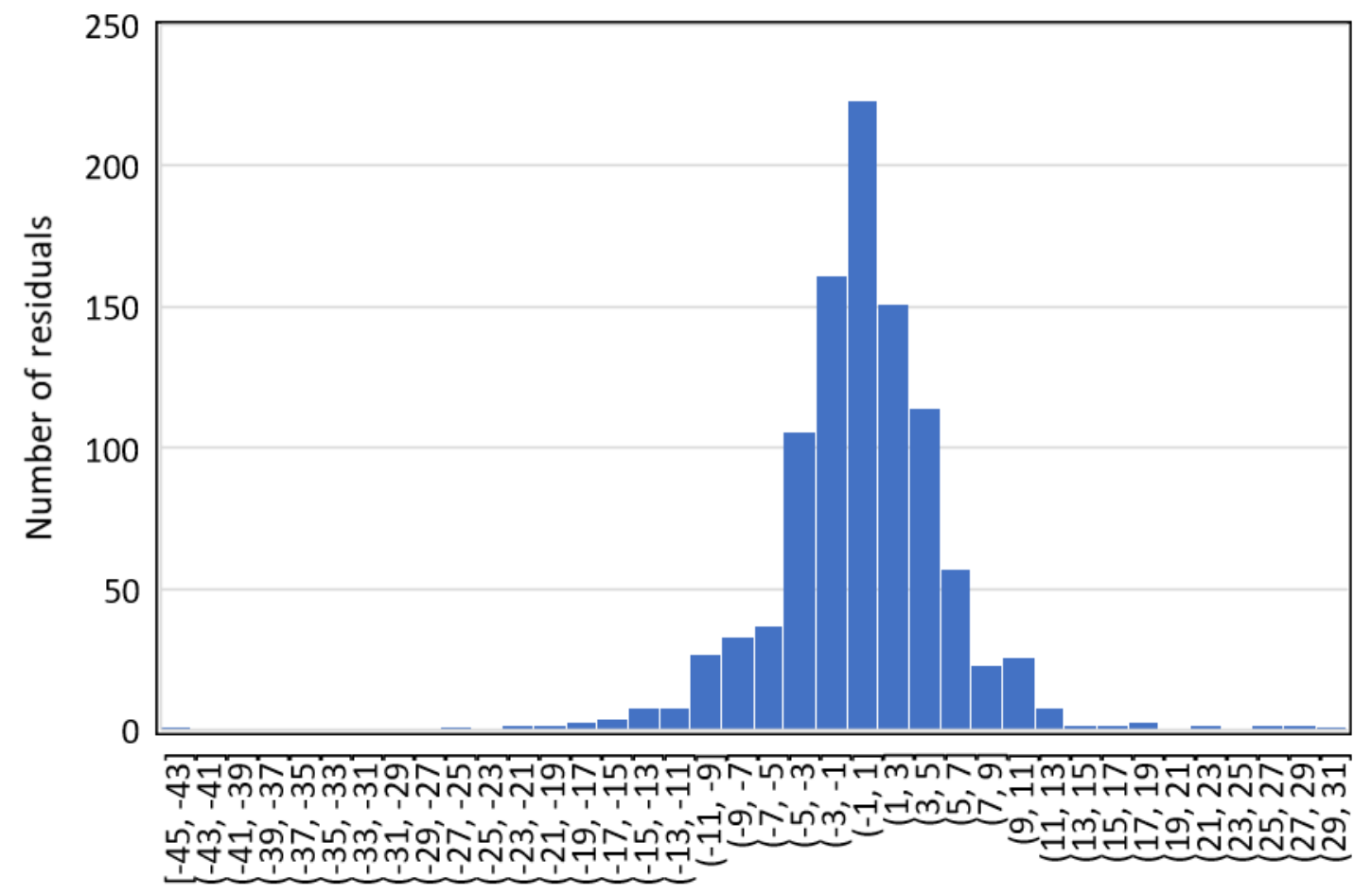

Water level residuals, in meters

Figure 22. Histogram of water-level residuals for all calibration data for all model periods. 
Streamflow is also relatively well represented by the model (fig. 23), given the limited number of parameters used, and other model limitations.

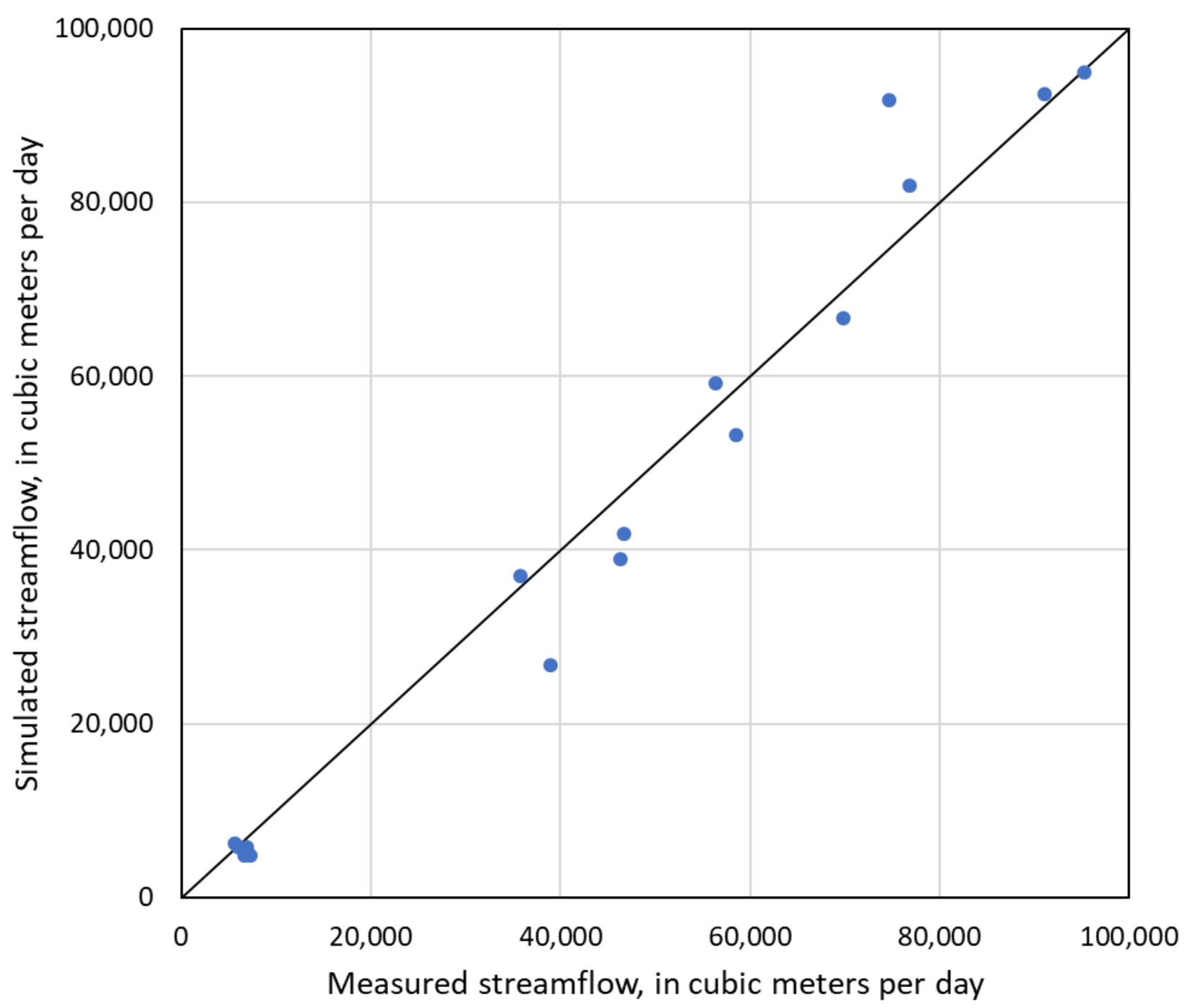

Figure 23. Simulated and measured streamflow for optimum parameters identified by calibration for all model periods. 


\section{Effects of Recharge and Withdrawals on Groundwater-Flow Paths}

MODPATH 7 (Pollock, 2016) was used to delineate groundwater-flow paths to discharge areas under steady-state flow for conditions in 1999, 2010, 2013, 2016, and 2017. The 2017 simulation uses the same recharge rate as the 2016 simulation, but well withdrawals are reduced further (table 6; Senior and others, 2020). For simulations of recharge discharging to wells or streams, 1 particle was used in each model cell; in these simulations, wells pumping at small rates may not capture any particles.

The overall water budget of the steady-state model consists of a balance between the inflows to and outflows from the aquifer. Inflows are primarily recharge, with some stream loss entering the aquifer, and outflows are composed of groundwater discharge to streams (base flow) and well withdrawals (table 10). Areas of recharge that discharge either to wells or to streams can be visualized through particle tracking using MODPATH.

Table 10. Simulated groundwater budget.

\begin{tabular}{llrrrrr}
\hline \multirow{2}{*}{ Water budget component } & \multicolumn{5}{c}{ Model area budget, in inches per year } \\
\cline { 3 - 7 } \multicolumn{2}{l}{ Inflow } & $\mathbf{1 9 9 9}$ & $\mathbf{2 0 1 0}$ & $\mathbf{2 0 1 3}$ & $\mathbf{2 0 1 6}$ & $\mathbf{2 0 1 7}$ \\
\multirow{2}{*}{ Outflow } & Recharge & 9.98 & 11.09 & 11.09 & 7.76 & 7.76 \\
& Wells & 2.75 & 2.25 & 2.16 & 2.06 & 1.77 \\
& Streams $^{1}$ & 7.22 & 8.83 & 8.93 & 5.70 & 5.99 \\
\hline
\end{tabular}

\begin{tabular}{cccccc} 
Water budget outflow & \multicolumn{5}{c}{ Model area outflow, as percent of inflow } \\
\hline Wells & 27.6 & 20.3 & 19.5 & 26.6 & 22.8 \\
Streams $^{1}$ & 72.4 & 79.7 & 80.5 & 73.4 & 77.2 \\
\hline
\end{tabular}

${ }^{1}$ Net outflow to streams $=$ total outflow to streams minus inflow from streams

PFAS contamination in groundwater has been identified at and near the Willow Grove and Warminster bases. To help understand groundwater migration of contaminants, regional flow paths are delineated from identified possible locations of PFAS contamination to either streams or wells for the five time periods. The locations of PFAS sources on the bases are not well known, but were estimated from reported 2014-17 data on elevated PFAS concentrations in shallow monitoring wells, sites where aircraft crashed, and other information (Tetra Tech, 2014; Leidos, 2018; Resolution Consultants, 2019). Results for two time periods are presented in this section to show examples of changes in flow paths owing to changes in recharge and well withdrawals. Simulated water levels, areas contributing recharge to wells, and flow paths from sources for all time periods are presented in appendix 3. For simulations of groundwater flow paths from possible PFAS sources on the bases to wells or streams, nine particles were used in each model source cell. 


\section{Conditions}

The 1999 conditions (based on withdrawal rates compiled for the 1990s) include the largest well withdrawals, so a higher proportion of recharge is captured by wells rather than streams compared with other time periods.

Simulated water levels (fig. 24) reflect surface topography and groundwater discharge to streams under average recharge conditions but are also influenced by drawdowns near large production wells. Both Willow Grove NASJRB and NAWC Warminster straddle groundwater level highs, corresponding to topographic ridges. Groundwater flow is perpendicular to the water-level contours, from high to low altitudes, with some deviation caused by the horizontal anisotropy $(\mathrm{Ky} / \mathrm{Kx})$ within bedding planes and $(\mathrm{Kz} / \mathrm{Kx})$ across the dipping bedding planes.

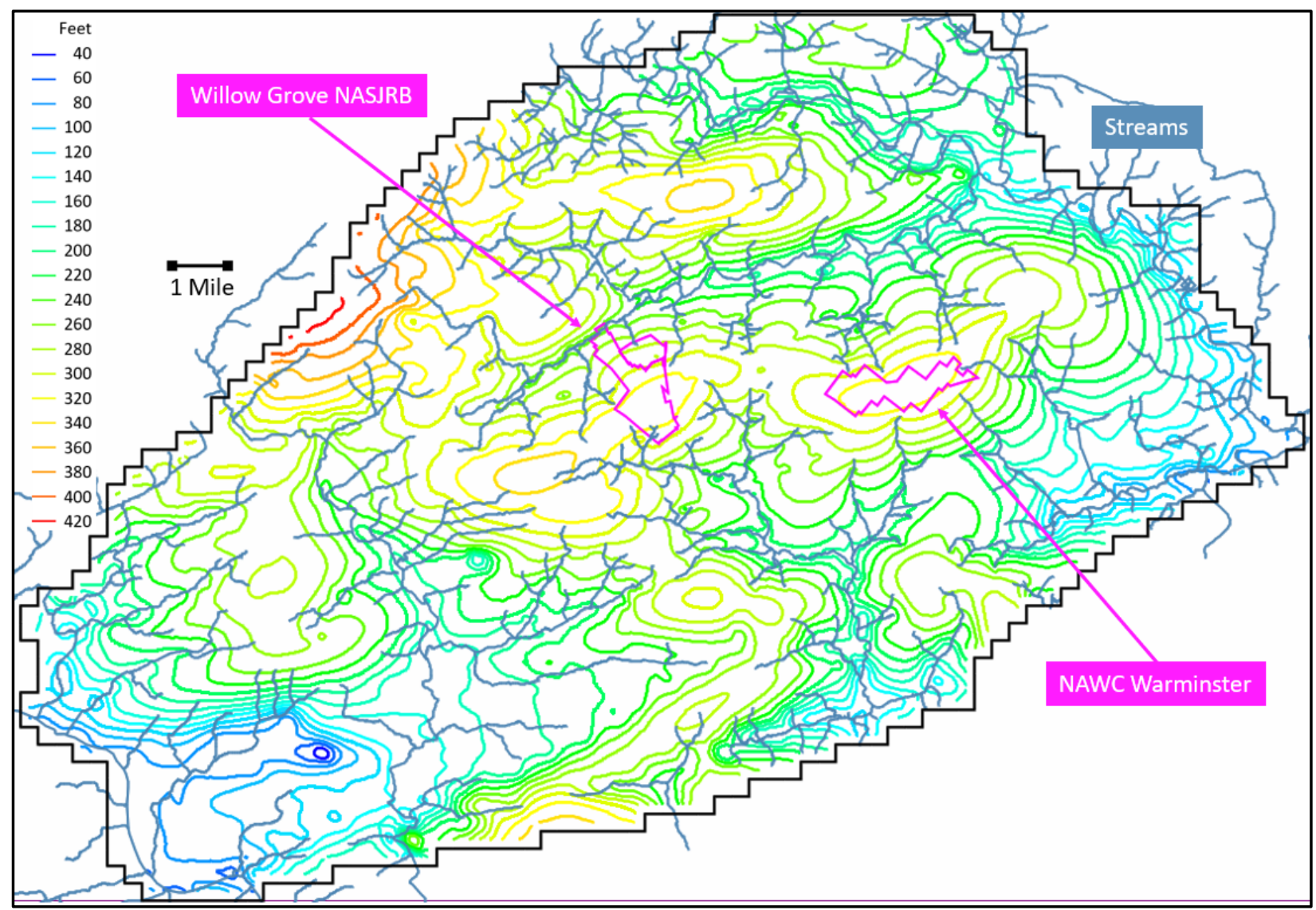

Figure 24. ModelMuse screenshot of simulated potentiometric surface in model layer 1 for 1999 conditions. The contour interval is 20 feet. 
In 1999 the withdrawal rates were large relative to the annual average recharge, so a large portion of the model area is simulated to provide recharge to wells (fig. 25). Some wells are deriving recharge from adjacent topographic drainage basins, which indicates that the surfacewater basins and groundwater basins do not fully coincide.

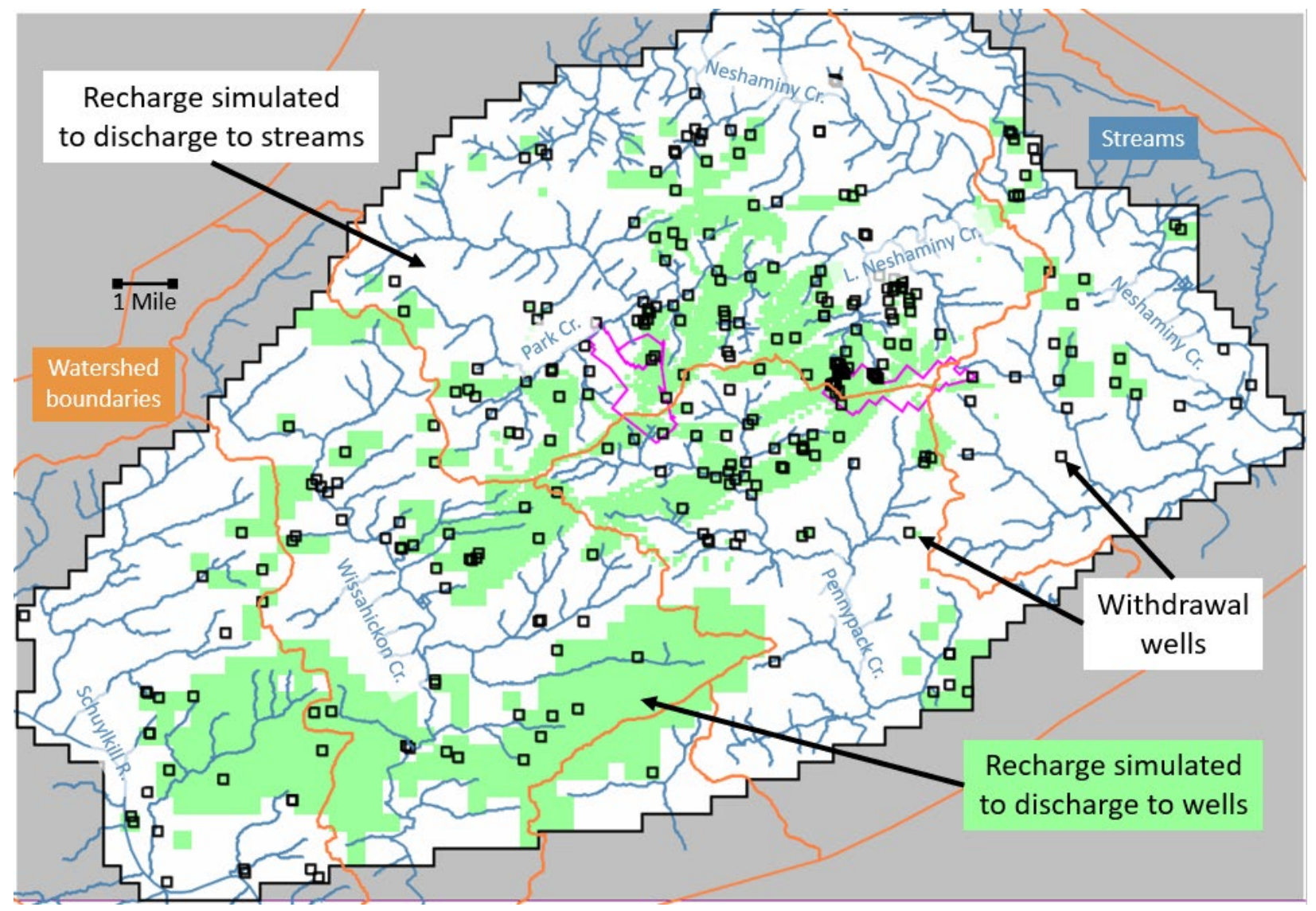

Figure 25. ModelMuse screenshot of simulated areas that contribute recharge to discharging wells (green) and streams (white) for 1999 conditions. Bases shown in magenta outline. 
Regional groundwater-flow paths are delineated from possible sources at Willow Grove and Warminster for 1999 steady-state flow conditions (fig. 26). Simulated results suggest that advective transport of contaminants under 1999 conditions is limited to a mile or two from the bases.

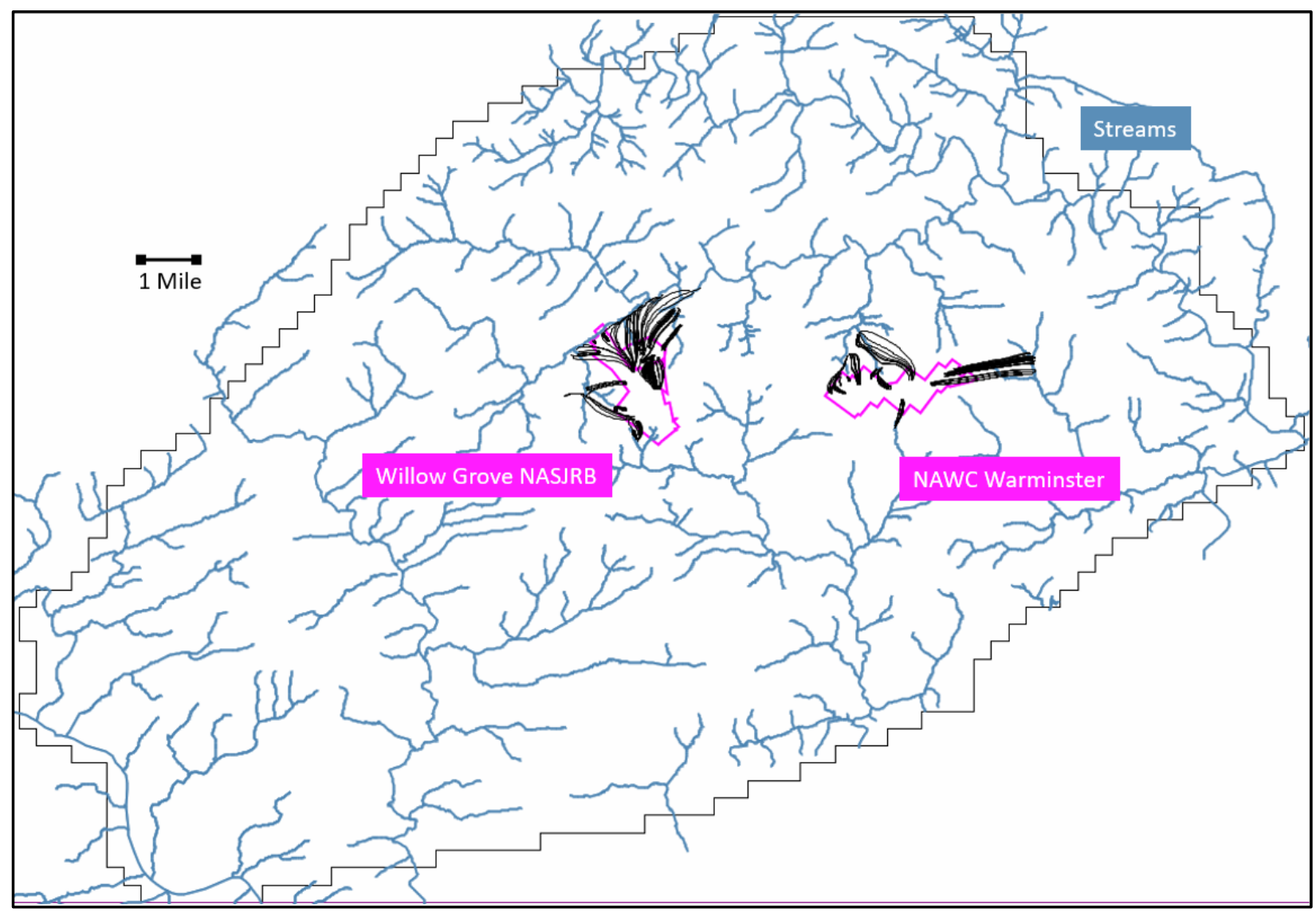

Figure 26. ModelMuse screenshot of simulated regional groundwater-flow paths (black) from locations of possible per- and polyfluoroalkyl substances (PFAS) contamination in groundwater for 1999 conditions. 
Regional groundwater-flow paths from sources at Willow Grove discharge to streams and wells near the base (fig. 27). Flow paths to the northwest of the base are limited to the area between the base and Park Creek. Several flow paths discharge to large production wells near the base to the southeast and northeast. The base production wells at HAGS were simulated to capture flow paths from possible sources at the base under 1999 conditions.

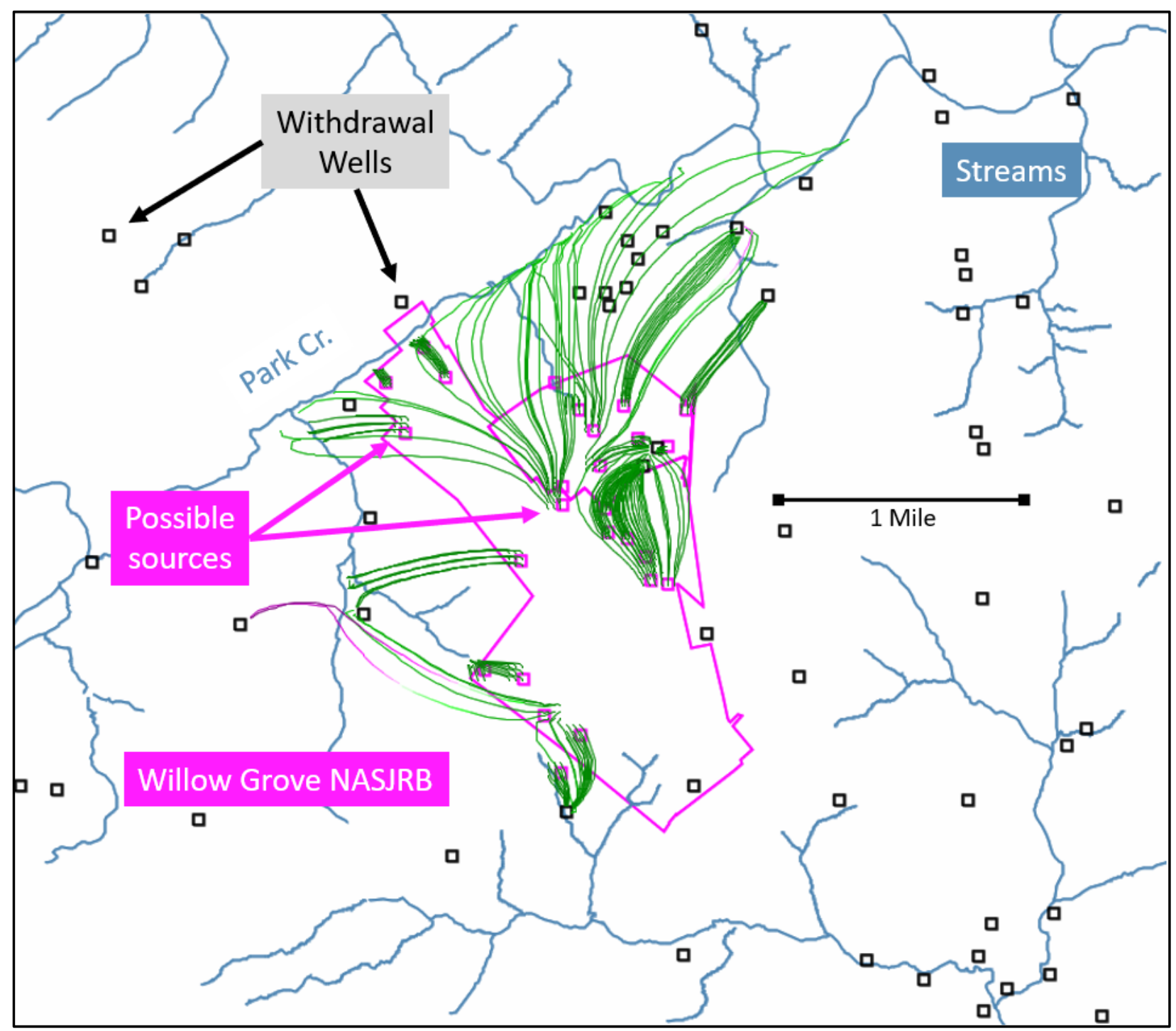

Figure 27. Detail of ModelMuse screenshot of simulated regional groundwater-flow paths for 1999 conditions near Willow Grove. Pink squares represent locations of possible per- and polyfluoroalkyl substances (PFAS) contamination in groundwater. Colors along paths range from green for relatively short travel times to magenta for relatively long travel times. 
Regional groundwater-flow paths from sources at Warminster discharge to streams and wells near the base (fig. 28). Flow paths from sources on the east side of the base discharge nearly due east to Iron Works Creek, part of the Neshaminy Creek drainage. Flow paths from the possible source on the base's southern border discharge to Southampton Creek in the Pennypack Creek drainage. Flow paths from possible sources in the northwest part of the base discharge to local streams and to several production wells and remediation wells under 1999 conditions.

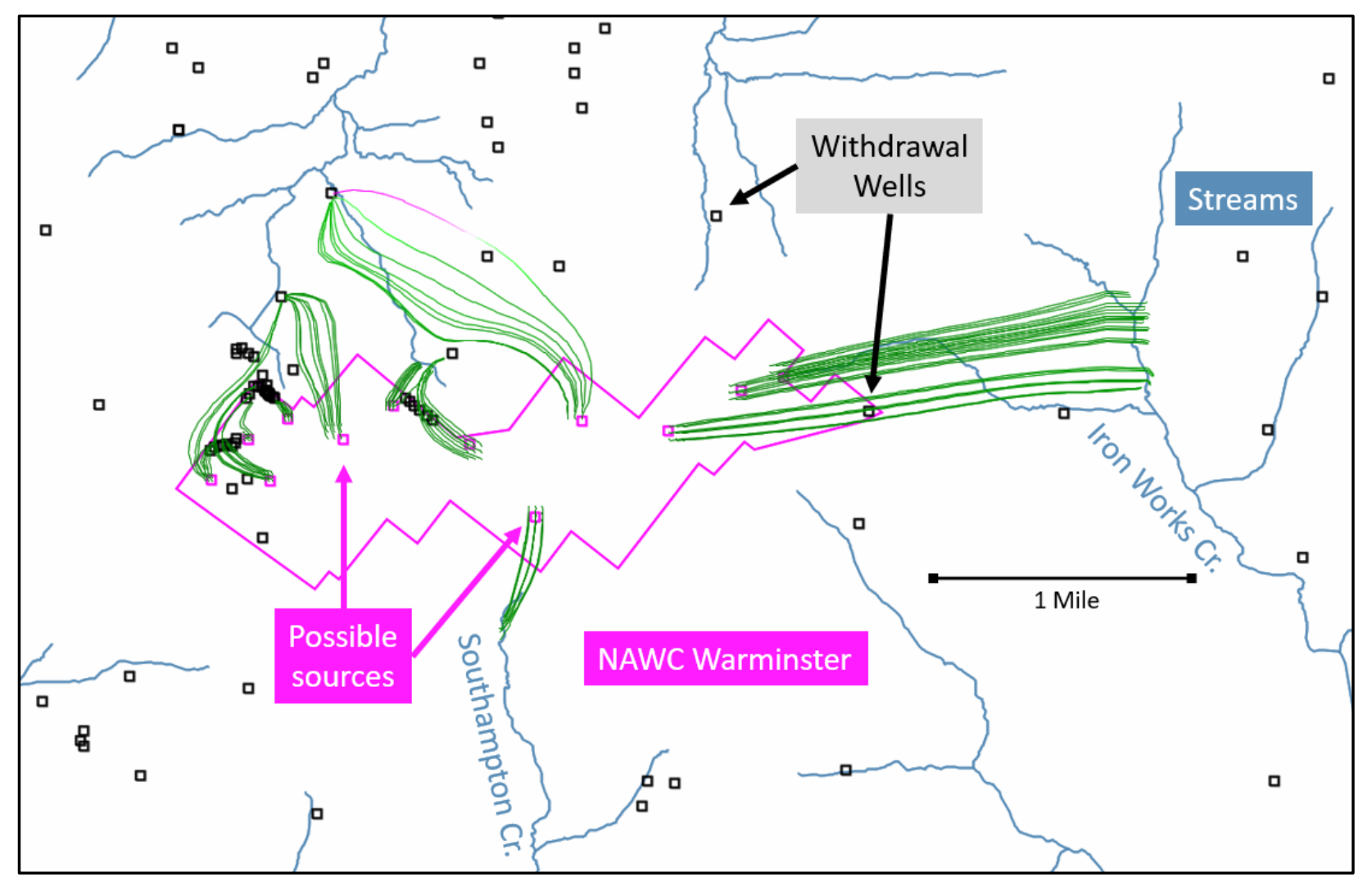

Figure 28. Detail of ModelMuse screenshot of simulated regional groundwater-flow paths for 1999 conditions near Warminster, with withdrawal wells in black. Pink squares represent locations of possible per- and polyfluoroalkyl substances (PFAS) contamination in groundwater. Colors along paths range from green for relatively short travel times to magenta for relatively long travel times. 


\section{Conditions}

The 2017 time period has the smallest groundwater withdrawals of the simulated scenarios (tables 6 and 10; fig. 10). This time period was not used for model calibration.

Under 2017 conditions, regional groundwater-flow paths from sources at Willow Grove discharge to streams and wells near the base (fig. 29). Flow paths to the northwest of the base are limited to the area between the base and Park Creek. Because fewer wells were pumping in 2017 than in 1999, most of the flow paths from the north side of the base discharge to local streams instead of wells. With smaller withdrawals from nearby wells, a few flow paths flow deeper in the aquifer and discharge to streams farther away from the base than in 1999 conditions.

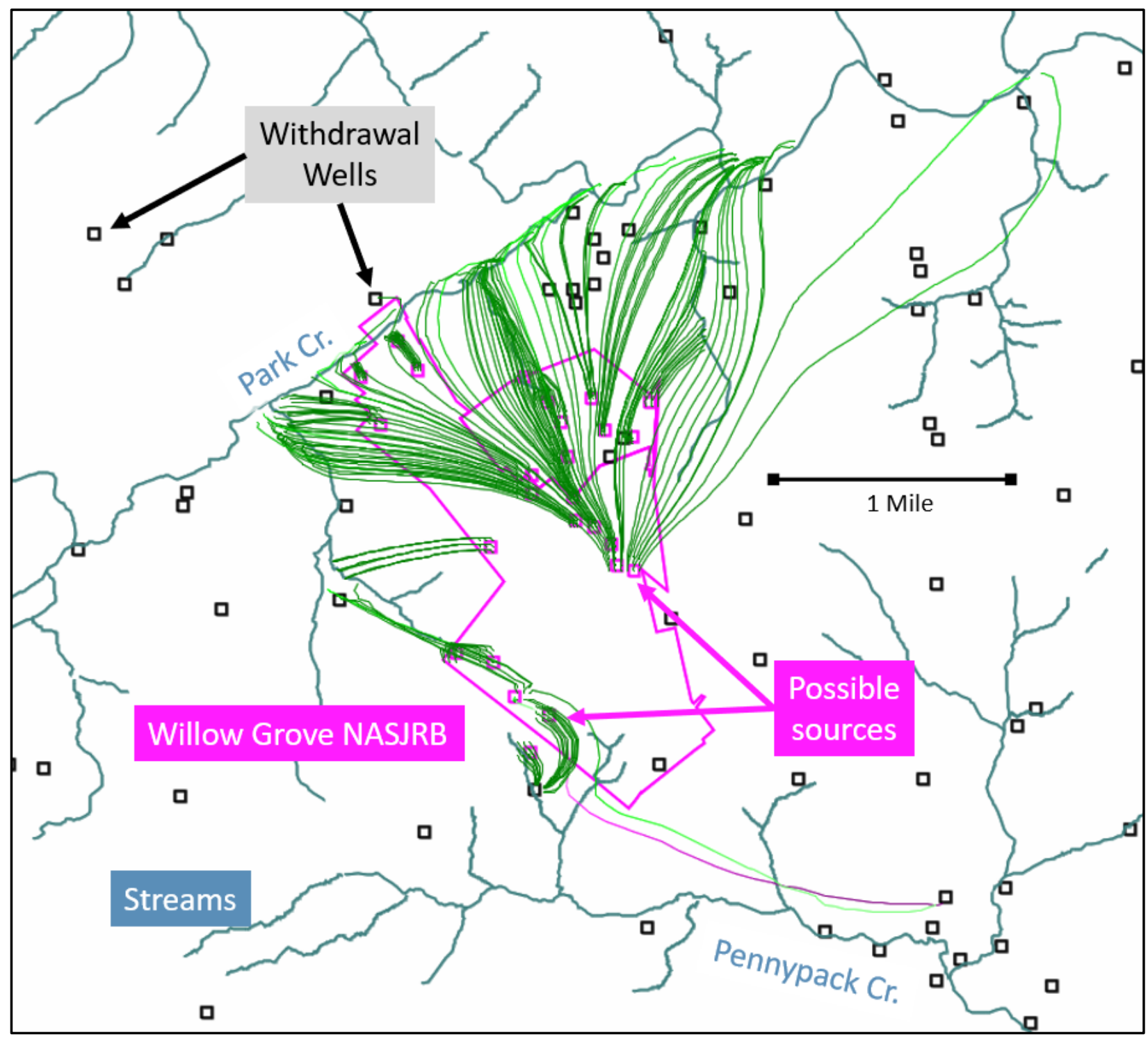

Figure 29. Detail of ModelMuse screenshot of simulated regional groundwater-flow paths for 2017 conditions near Willow Grove, with withdrawal wells in black. Pink squares represent areas of possible perand polyfluoroalkyl substances (PFAS) contamination in groundwater. Colors along paths range from green for relatively short travel times to magenta for relatively long travel times. 
Regional groundwater-flow paths from sources at Warminster under 2017 conditions discharge to streams and wells near the base (fig. 30). As in 1999, flow paths from sources on the east side of the base discharge nearly due east to Iron Works Creek, part of the Neshaminy Creek drainage. Likewise, flow paths from the possible source on the base's southern border discharge to Southampton Creek in the Pennypack drainage, although at lower altitudes in the stream, likely a result of reduced recharge in 2017 compared to 1999 conditions. Although remediation well pumping is similar, other well withdrawals are reduced in 2017 compared to 1999 conditions. Paths from the possible source in the center of the Warminster base flow to the northwest, north, and northeast, while under the larger withdrawal 1999 conditions paths from that source flowed to the northwest. The 2017 flow paths are also deeper and discharge to more distant locations.

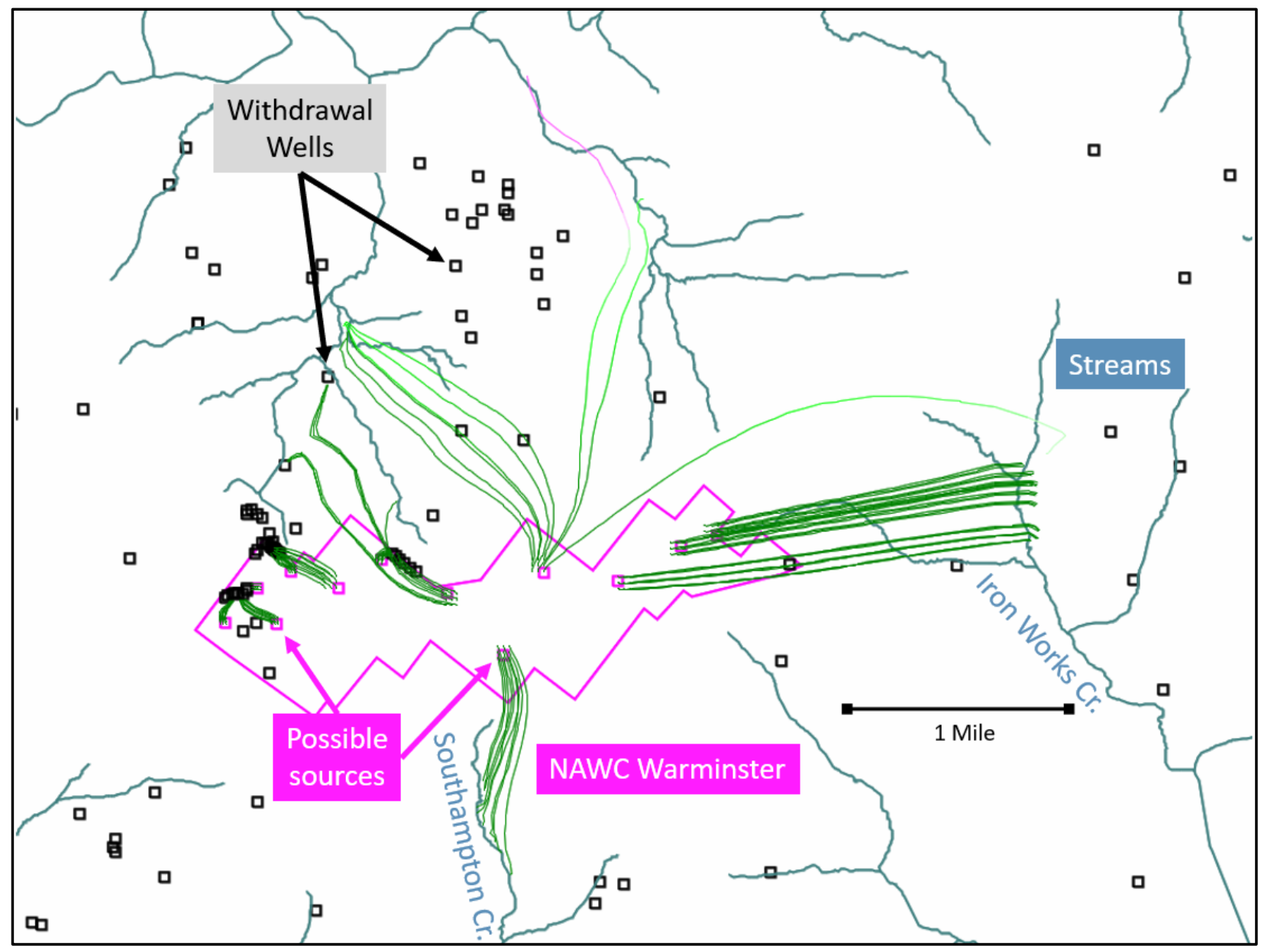

Figure 30. Detail of ModelMuse screenshot of simulated regional groundwater-flow paths for 2017 conditions near Warminster, with withdrawal wells in black. Pink squares represent areas of possible perand polyfluoroalkyl substances (PFAS) contamination in groundwater. Colors along paths range from green for relatively short travel times to magenta for relatively long travel times. 


\section{Groundwater-Flow Paths and PFAS Contamination in Wells}

The regional flow paths are different for the different simulation periods owing to changes in model recharge rates and well withdrawals. A composite overlay of the simulated regional flow paths from possible PFAS sources for all simulated conditions provides a useful understanding of the potential locations of groundwater contaminated by possible PFAS sources at the bases. Such information could also help guide further delineations of contamination in the study area.

The ANG and Navy began sampling groundwater from existing residential wells and new monitor wells drilled on the bases, and base flow in streams at and near the bases, after PFAS was first detected in supply wells in 2014. The ANG and Navy also sampled residential wells for PFAS compounds in areas surrounding the Willow Grove and Warminster bases in 2015. In cooperation with the Navy, EPA sampled residential wells near Willow Grove from 2014 through mid-2017. Maps prepared by the Navy and the ANG and their contractors showing the extent of private-well sampling areas and levels of PFOA and PFOS concentrations in the wellwater samples relative to drinking-water LHAs indicate most exceedances occur near the bases (figs. 31 and 32, U.S. Navy, written commun., 2019).

The paths from the steady-state models do not represent the actual advective transport of contaminants in part because the aquifer system is not at steady state, and a moving contaminant will change direction as flow conditions change in response to long-term, seasonal, and shorterterm changes to recharge and pumping. For example, if a contaminant entered the aquifer in 1999 and did not discharge from the aquifer until 2017, it would be affected by all the conditions represented in the simulations above, at different points along its path.

A composite visualization of the paths for all simulated conditions was constructed to approximate the areas of the aquifer that may have been impacted by possible PFAS sources. Each set of paths for a simulated year was colored gray and made partly transparent, and all sets for different years were overlaid (figs. 33-35). The composite paths are darkest where paths from most or all the simulations overlap, light gray paths indicate areas where fewer simulations overlap, and the lightest gray paths are those for a single simulation, where no paths were simulated during other simulations.

Many of the off-base areas where PFAS concentrations in private residential wells exceed drinking-water LHA levels are on or near simulated composite regional groundwater-flow paths from possible PFAS contaminations sources at HAGS and NASJRB Willow Grove and NAWC Warminster (figs. 33-35). The simulated composite regional groundwater-flow paths from potential PFAS contaminations sources are also consistent with the locations of numerous pumping wells where PFAS concentrations have exceeded LHA levels (not shown). Although evaluation of detailed groundwater/surface-water interaction is beyond the scope of this report, results from stream sampling near the Willow Grove base to date (Leidos, 2018; Resolution Consultants, 2019) are generally consistent with areas where simulated groundwater-flow paths discharge to streams. 


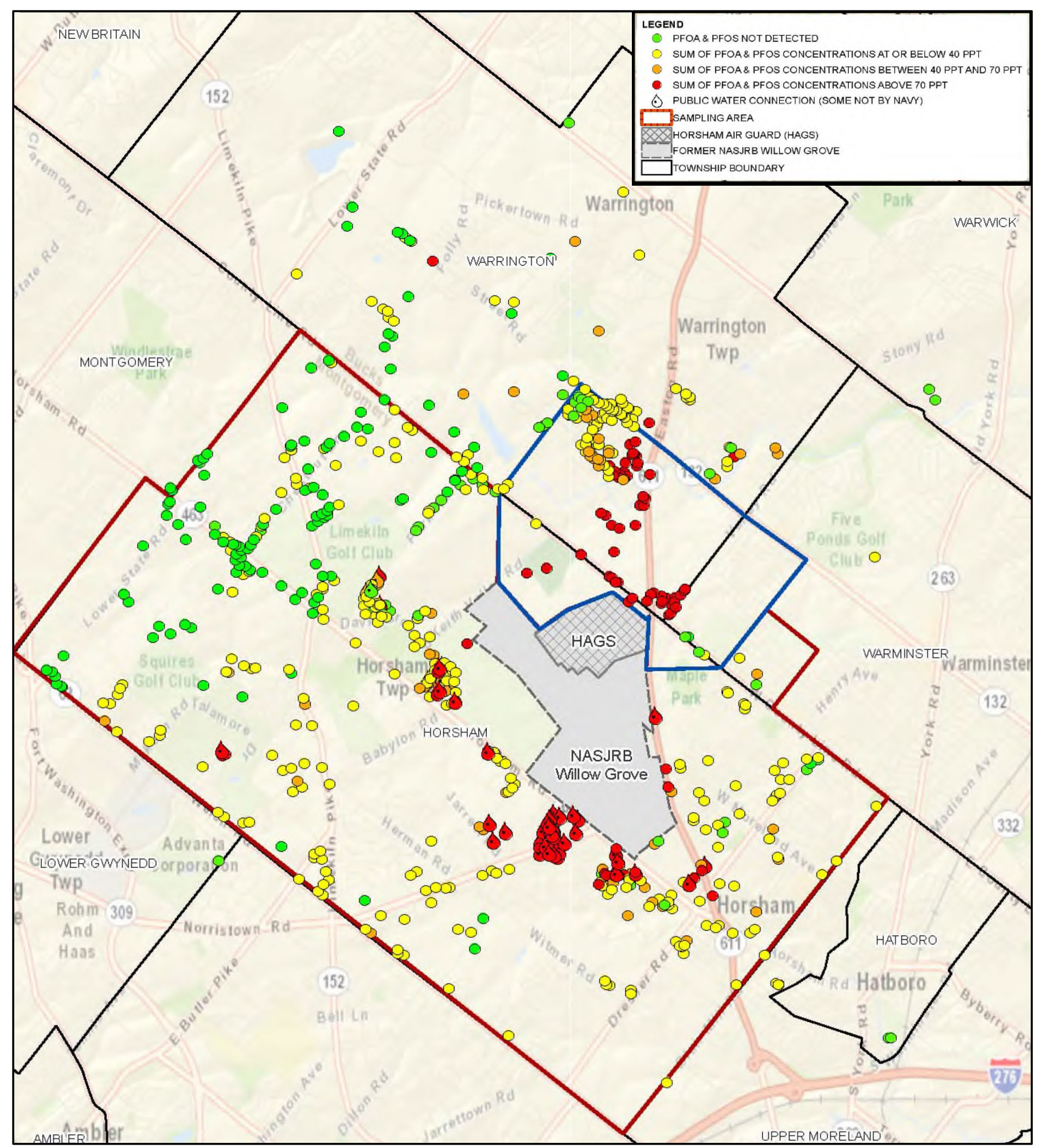

Figure 31. Private-well sampling areas and levels of perfluorooctane sulfonate (PFOS) and perfluorooctanoic acid (PFOA) in well-water samples relative to drinking-water health advisories for Horsham Air Guard Station and the former Naval Air Station Joint Reserve Base Willow Grove as of September 2019 (U.S. Navy, 2019a; PPT, parts per trillion). 


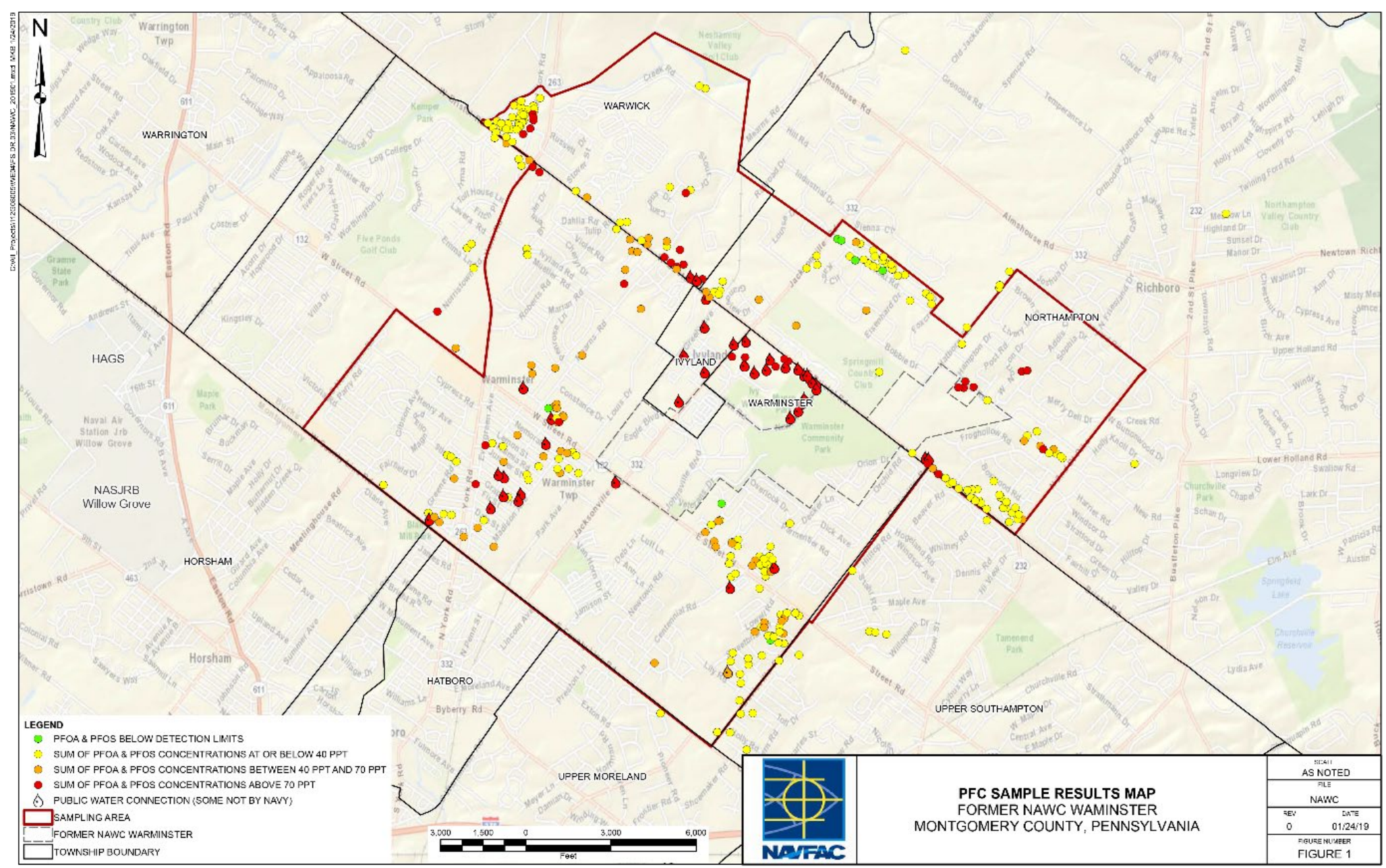

Figure 32. Private-well sampling areas and levels of perfluorooctane sulfonate (PFOS) and perfluorooctanoic acid (PFOA) in well-water samples relative to drinking-water health advisories for the former Naval Air Warfare Center Warminster, Bucks County, Pennsylvania as of January 2019 (U.S. Navy, 2019b; PPT, parts per trillion). 


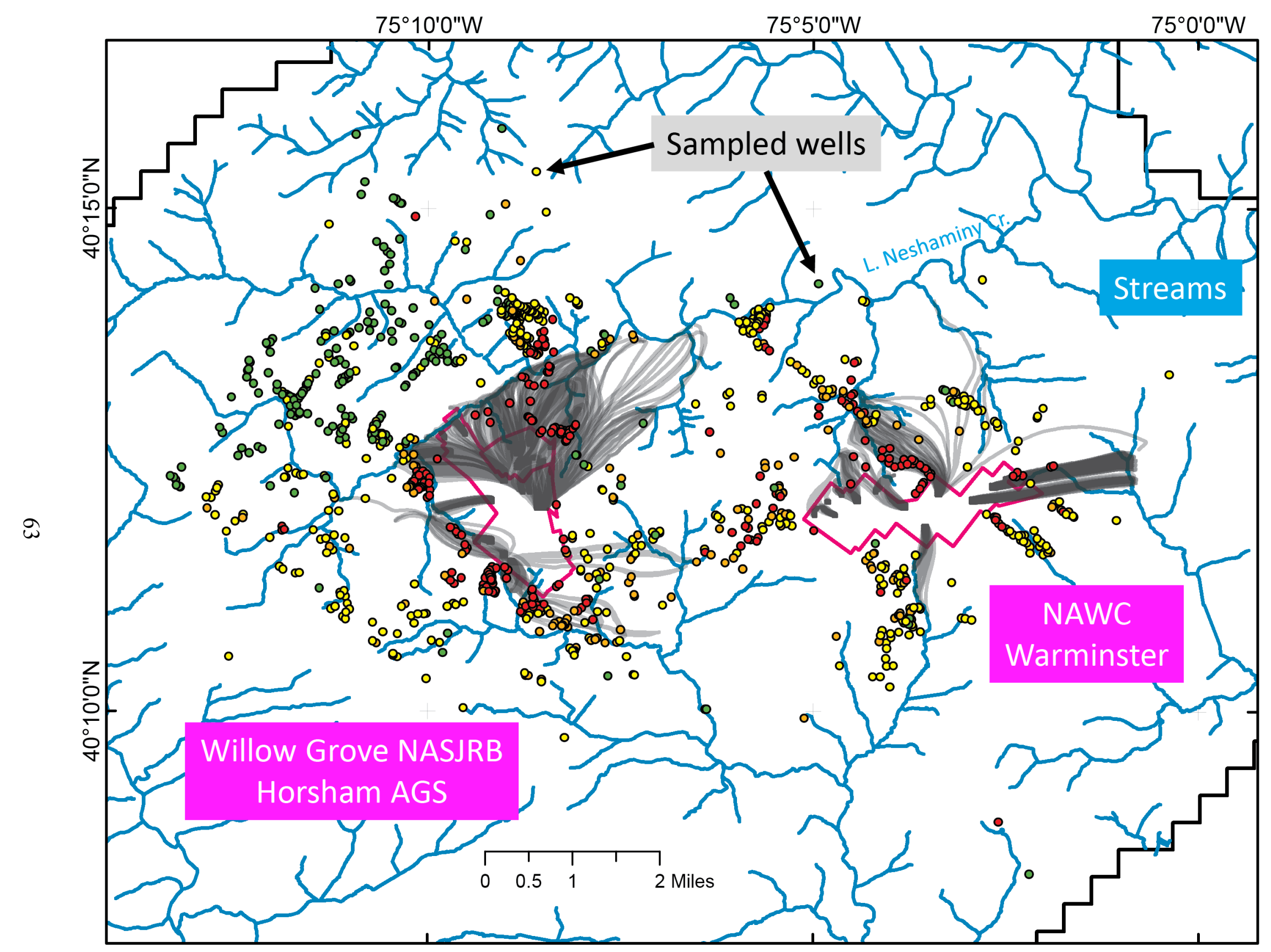

Figure 33. Composite simulated regional groundwater-flow paths from possible per- and polyfluoroalkyl substances (PFAS) contamination sources at Willow Grove and Warminster for conditions in 1999, 2010, 2013, 2016, and 2017 and maximum levels of perfluorooctane sulfonate (PFOS) and perfluorooctanoic acid (PFOA) in 2014-2018 well-water samples relative to drinking-water health advisories (see figs. 31 and 32 for symbol color explanation). Water-quality data from the U.S. Navy (written commun., 2019). 


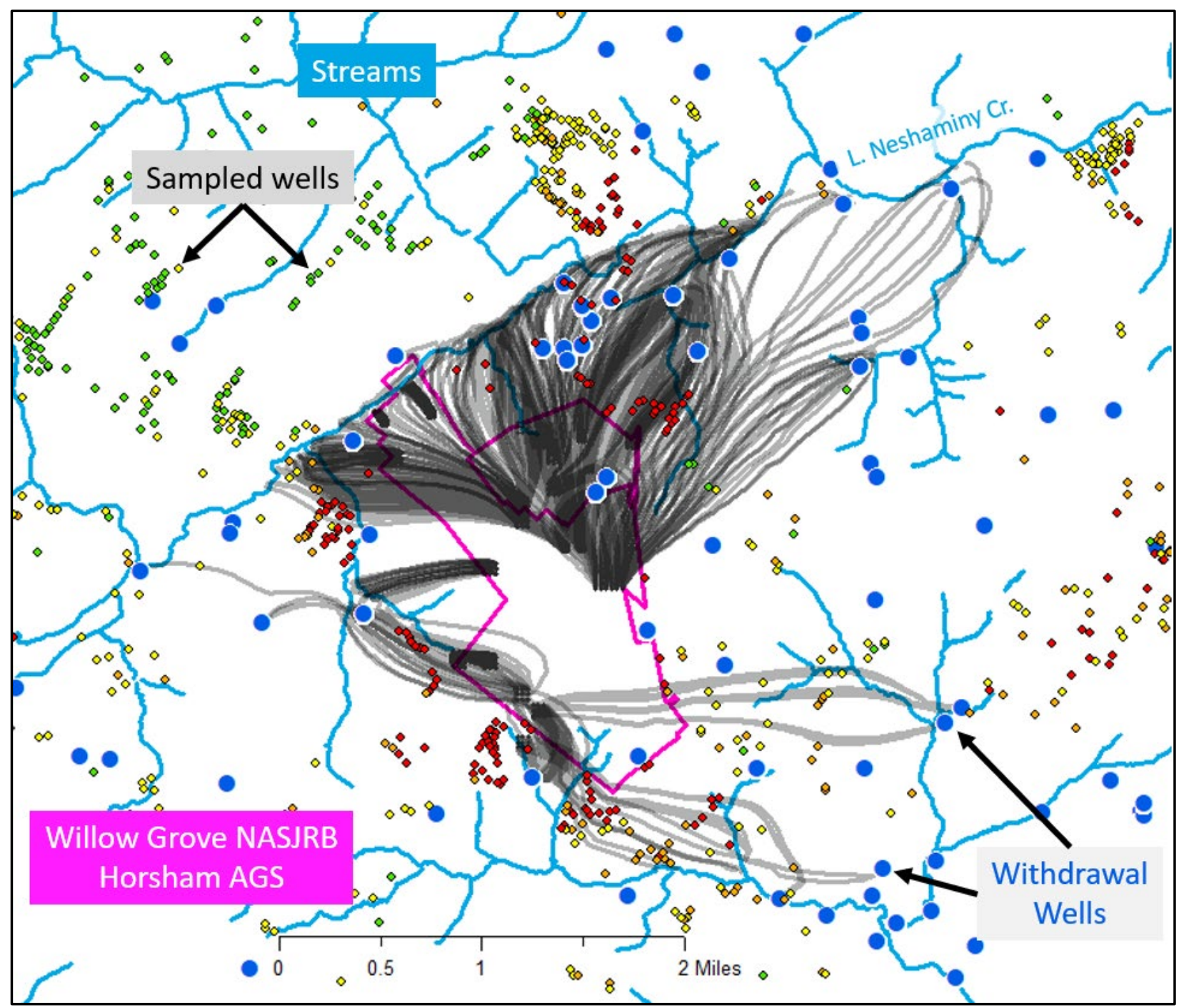

Figure 34. Detail at Willow Grove of composite simulated regional groundwater-flow paths from possible per- and polyfluoroalkyl substances (PFAS) contamination sources for conditions in 1999, 2010, 2013, 2016, and 2017 and maximum levels of perfluorooctane sulfonate (PFOS) and perfluorooctanoic acid (PFOA) in 2014-2018 well-water samples relative to drinking-water health advisories (see figs. 31 and 32 for symbol color explanation). Water-quality data from the U.S. Navy (written commun., 2019). 


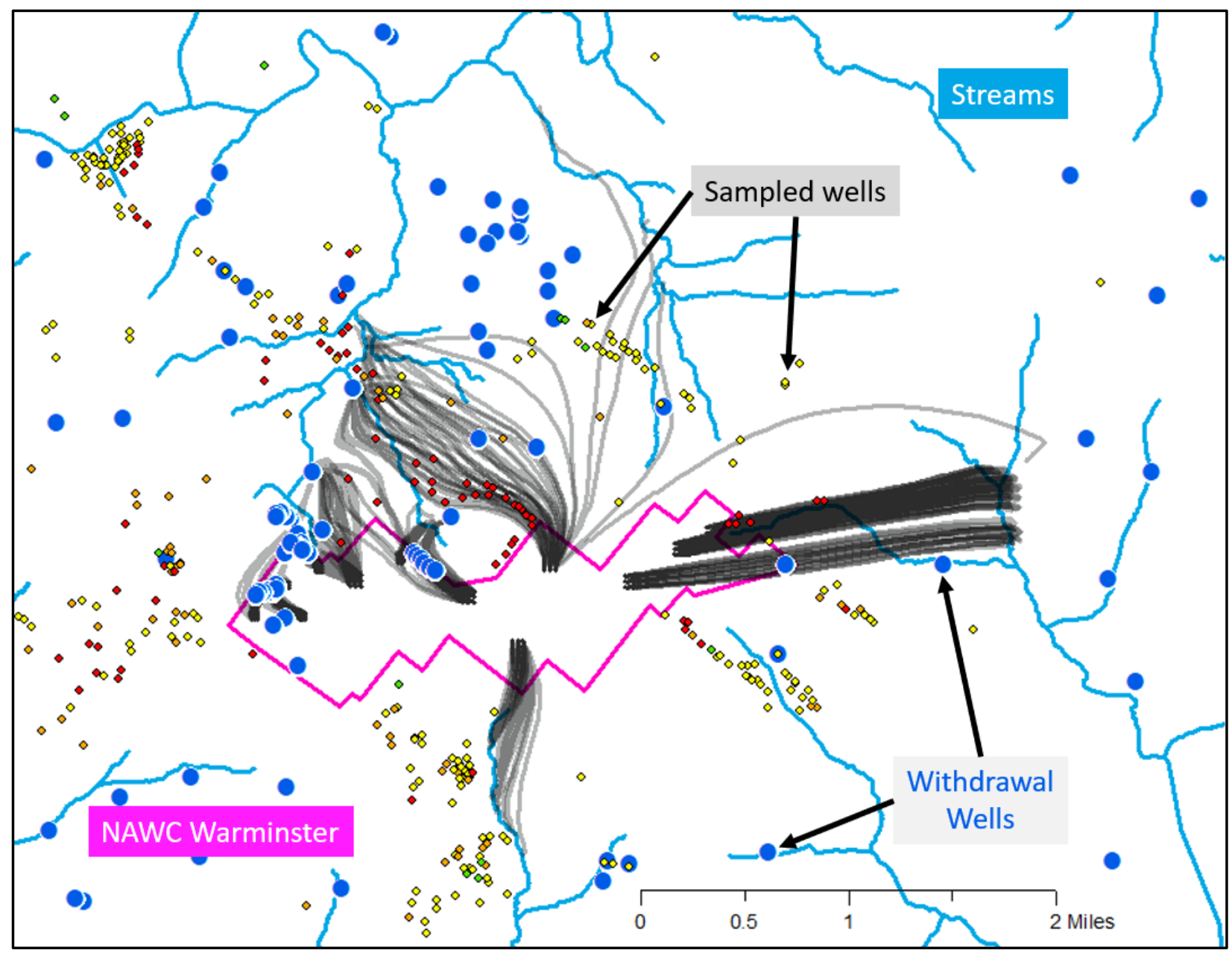

Figure 35. Detail at Warminster of composite simulated regional groundwater-flow paths from possible per- and polyfluoroalkyl substances (PFAS) contamination sources for conditions in 1999, 2010, 2013, 2016, and 2017 and maximum levels of perfluorooctane sulfonate (PFOS) and perfluorooctanoic acid (PFOA) in 2014-2018 well-water samples relative to drinking-water health advisories (see figs. 31 and 32 for symbol color explanation). Water-quality data from the U.S. Navy (written commun., 2019).

Some of the areas where well concentrations have exceeded drinking-water LHA levels, however, lie beyond the extent of the composite simulated regional groundwater-flow paths from potential PFAS sources at HAGS, Willow Grove NASJRB and NAWC Warminster. These areas include a cluster of wells on the north side of Little Neshaminy Creek and north of the Willow Grove base and a cluster of wells just southwest of the Willow Grove base (figs. 33, 34). There are also wells as much as about 2 mi southwest and northwest of the NAWC Warminster base (figs. 33, 35). Possible explanations for the lack of alignment between simulated regional flow paths and observed, relatively elevated PFAS concentrations include model error and (or) the presence of unidentified PFAS sources, including sources unrelated to Navy or ANG activities, or mechanisms of PFAS transport. 


\section{Stream Loss to Groundwater}

When groundwater levels near streams are below the stream stage, surface water from the stream infiltrates to groundwater. This process is enhanced where pumping wells near streams are withdrawing groundwater at a high rate, creating groundwater-level drawdown near the well. Groundwater levels are also lowered when recharge is reduced, for example during late summer months when evapotranspiration is high. Contaminants in streams may be transported to the groundwater under these conditions.

Although the regional model was not specifically designed to examine groundwater/surface-water interactions, simulated stream infiltration to groundwater is prevalent for the 1999 flow conditions, the period with the largest well withdrawals simulated. Stream loss was simulated at several locations on Park Creek and Little Neshaminy Creek downstream from Willow Grove NASJRB (fig. 36). These locations are mostly near pumping wells and downgradient of the diabase dike. The dike may contribute to stream loss by acting as a subsurface dam, raising groundwater levels on the upstream side of the dike, but lowering levels on the downstream side. Contaminants that discharge to Park Creek through base flow, or from surface runoff, or from point discharges, could infiltrate back into the aquifer.

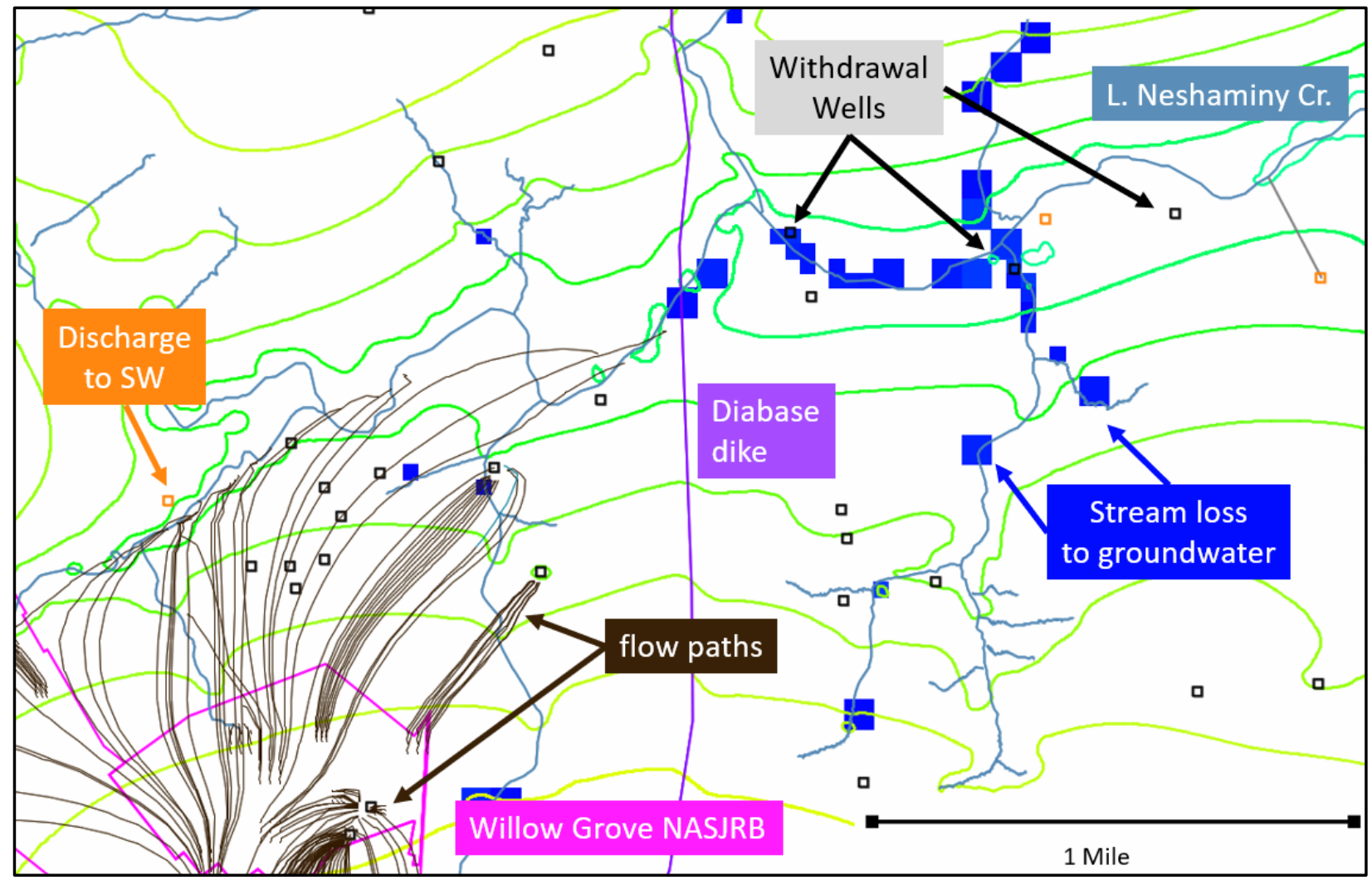

Figure 36. Detail near Willow Grove, Park Creek, and Little Neshaminy Creek of ModelMuse screenshot of simulated potentiometric surface in model layer 1, regional flow paths from possible per- and polyfluoroalkyl substances (PFAS) contamination in groundwater, and locations of stream loss for conditions in 1999. Contour interval is $20 \mathrm{ft}$ (see fig. 26). 
Well withdrawals in the Willow Grove area were much less in the 2017 simulation than in the 1999 simulation (fig. 18). As a result, less streamflow loss to groundwater was simulated in 2017 (fig. 37) and contaminants that enter Little Neshaminy Creek near the Willow Grove base would flow downstream, rather than infiltrate to groundwater from Little Neshaminy Creek.

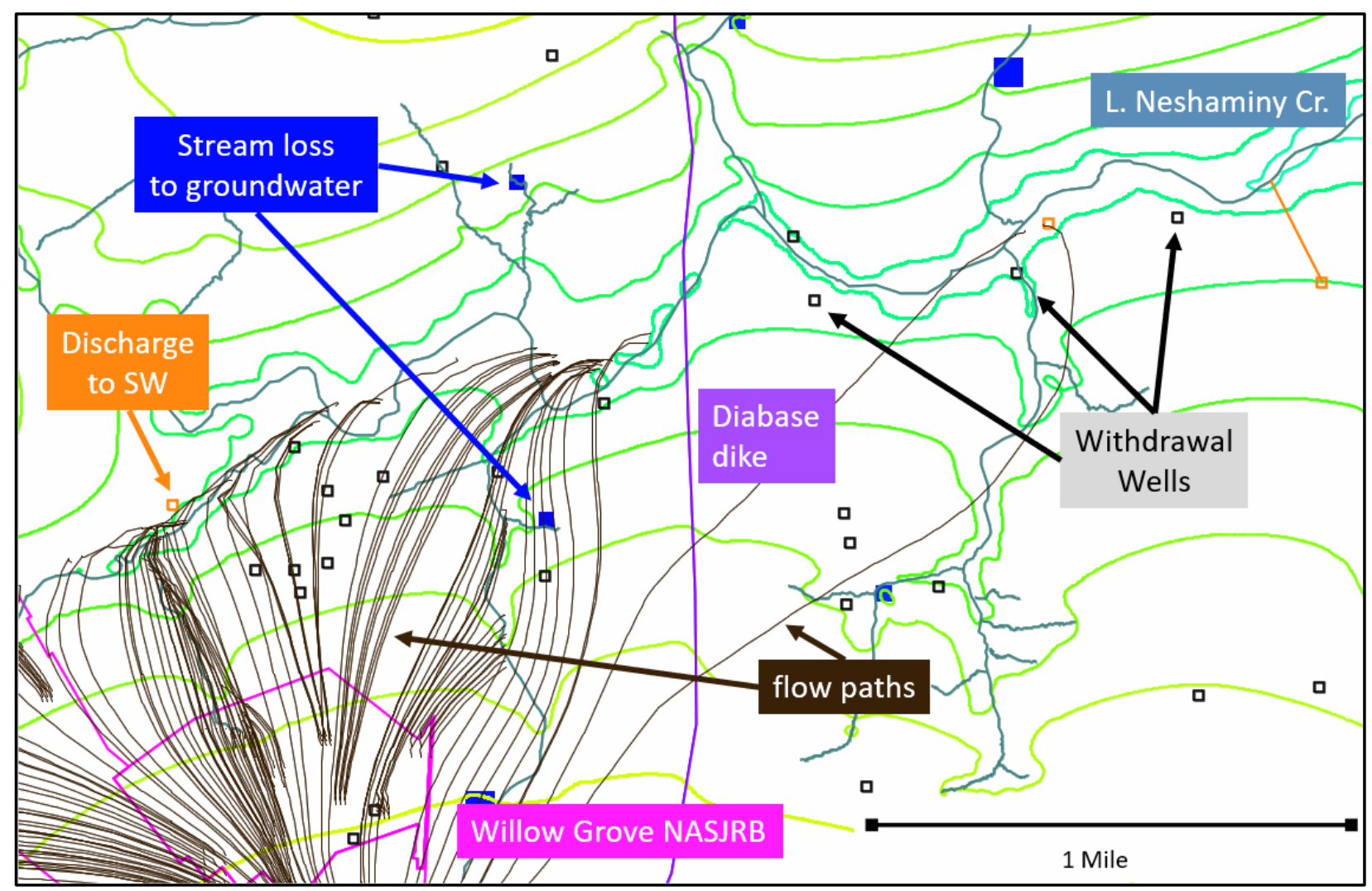

Figure 37. ModelMuse screenshot detail near Willow Grove, Park Creek, and Little Neshaminy Creek of the simulated potentiometric surface in model layer 1 , regional flow paths from possible per- and polyfluoroalkyl substances (PFAS) contamination in groundwater, and locations of stream loss for conditions in 2017. The contour interval is $20 \mathrm{ft}$ (see appendix 3, fig. 3.21). 


\section{Limitations and Suggestions for Improvements}

The extent to which the simulations in this report correspond to field conditions cannot be fully verified or validated, owing to the lack of data and the simplifications made in the preliminary conceptual and numerical model developed in this report. Some of the major limitations, and suggestions for improvements, are described in this section.

The model grid cells and layers are large relative to the scale of individual fractures and fracture zones through which the bulk of the groundwater is transported. Most of the aquifer space is composed of unfractured rock that does not contribute substantially to the aquifer's hydraulic conductivity. The model discretizes the aquifer into large blocks (cells) that represent the bulk properties of the aquifers and describe the flow paths at the scale of the cells, or larger. Nonetheless, the model is considered to usefully approximate regional flow conditions and paths.

The regional model can provide boundary conditions for smaller models with higher grid resolution. The smaller models would be useful in further exploring the relation between possible sources and contaminated private wells near the bases that do not appear on flow paths simulated with the regional model.

The model simulates steady-state flow conditions when actual flow conditions are transient. The transient conditions result from both long-term changes in pumping, variations in recharge, and short-term changes in pumping schedules, such as withdrawal wells cycling on and off each day. The flow conditions, and the resulting flow paths, change with time, but the steadystate model only represents unchanging average conditions. Transient flow models could simulate the impact of changes in recharge, pumpage, and well cycling on flow paths.

Available data indicate that streams lose water in selected stream reaches during lowflow conditions in late summer and where infiltration is induced by pumping wells. Contaminants present in surface water may enter the groundwater system through losing reaches but these possible contaminant pathways were not simulated by the model. Additional data on streamflow at more locations in the study area under various flow conditions would improve characterization of groundwater/surface-water interaction.

The stream stages specified in the model were interpolated from a DEM and do not accurately represent actual stages throughout the model domain. The representation of the exchange of water between groundwater and streams would be improved by more accurately assigning stream stages, through a better interpolation procedure or a finer model grid near streams.

All water levels in the model calibration are assumed to have the same weight, and thus to be of equal importance to the calibration. Some of the water-level data are correlated with other nearby measurements, especially at contaminated sites that have been the focus of detailed field investigations, and it may be appropriate to account for these correlations in the measurement weighting scheme (Hill and Tiedeman, 2007; Doherty, 2015).

Measurement weights could also be adjusted to account for data errors, for example those caused by estimating land surface at the well from a 1:24,000-scale topographic map for the older data records. Well-construction data are missing for some wells, and the measured water level may not be accurately assigned to the correct model layer without these data. Further, some wells may be open to a long interval, but represent the water level in a discrete fracture or fracture zone within that open interval. Wells for which such detailed characterization data are available could be carefully analyzed and assigned appropriate weights to increase their importance for model calibration. It may be useful to measure and compile detailed well 
characteristics data in important model areas. Other limitations to model results are associated with uncertainty and (or) incompleteness in water-use data and characterization.

Further analysis of model residuals, especially for well and stream locations with high quality data, could suggest refinements to the model structure, which is presently limited to geologic zones based on the regional geology. The delineation of the upper Stockton from the middle and lower members of the Stockton Formation is hypothetical for the unmapped Bucks County portion of the model. Further geologic investigations and mapping could guide additional refinements of the conceptual and numerical models, especially near areas of interest.

The transport of contaminants in groundwater in fractured-rock aquifers is affected by a number or processes that are not included in the evaluation of flow paths in this report. These processes include dispersion, diffusion, sorption, and reactions. Also, additional information is needed about the distribution and magnitude of PFAS sources areas and transport mechanisms.

\section{Summary}

In 2014, groundwater samples from residential and public supply wells in the vicinity of two former U.S. Navy bases at Willow Grove and Warminster and an active Air National Guard Station at Horsham, in Montgomery and Bucks Counties, southeastern Pennsylvania, were found to have concentrations of perfluorooctanoic acid (PFOA) and perfluorooctane sulfonate (PFOS), which are per- and polyfluoroalkyl substances (PFAS), above U.S. Environmental Protection Agency (EPA) provisional health advisory (HA) levels. In 2016, the EPA established a new lower, lifetime HA of 70 parts per trillion for combined concentrations of PFOS and PFOA, which resulted in the shutdown of additional supply wells. Groundwater has been, and remains, a major source of drinking water supply in the area. At the request of the U.S. Navy, and in consultation with other Federal and State agencies and local stakeholders, the U.S. Geological Survey developed a numerical model to simulate regional groundwater flow and flow paths from potential PFAS sources at the bases under selected conditions during 1999-2017 at and near the former Willow Grove NASJRB and NAWC Warminster to provide information to help address the PFAS contamination in groundwater.

The bases and surrounding areas are underlain by Triassic geologic strata that form fractured-rock aquifers, which are recharged locally by precipitation. The sedimentary Triassic rocks (sandstones and shales), principally the Stockton Formation and overlying Lockatong Formation in the study area, generally strike east-northeast and dip to the northwest. Groundwater discharges locally to streams and wells. To support the model development and calibration, the U.S. Geological Survey compiled hydrologic data including water levels in wells, streamflow, point discharges to streams, groundwater withdrawals (pumping wells and quarries), and precipitation for selected periods between 1999-2017. Stream base flow, which can be used

to estimate recharge and was used for model calibration, was estimated by hydrograph separation methods at seven stream gages in the study area. Data from years 1999, 2010, 2013, and 2016 were used for model calibration and data for year 2017 were used for simulation only. Groundwater withdrawals near the bases from public supply and other large wells decreased substantially from the 1990 s to 2017 , increasing the proportion of groundwater recharge that discharged to local streams. 
A three-dimensional numerical model, MODFLOW 6, was used to simulate steady-state flow for the selected time periods with different recharge rates and well withdrawals. The model structure included seven layers of varying hydraulic properties and three-dimensional hydraulic conductivity tensor to estimate the anisotropic character of the dipping-bed fractured-rock aquifer in the area. The model was calibrated using 1,009 groundwater levels and 17 stream base-flow estimates using the parameter estimation software PEST++. The model simulations provide information on regional groundwater-flow paths and groundwater/surface-water exchanges, in relation to changes in water supply pumping and recharge rates.

Regional groundwater-flow paths from possible PFAS sources at the former bases were simulated for 1999, 2010, 2013, 2016, and 2017 conditions. Simulations showed that recharge at the bases discharged to withdrawal wells and local streams, generally within a mile or two of the bases. Supply and remediation wells at the bases captured some of the recharge on base areas of possible PFAS contamination, whereas other base recharge was simulated to flow to nearby public supply wells and streams, depending on water use and aquifer recharge conditions between 1999 and 2017. Locations of many residential wells near the bases identified by the U.S. Navy and Air National Guard as having elevated PFAS concentrations are generally consistent with the simulated flow paths from possible sources at the bases. However, there are some areas of observed PFAS contamination where no flow paths from base sources were simulated, indicating the presence of unknown PFAS sources, unidentified transport processes, and (or) model limitations. Additionally, no data are available on PFAS concentrations in groundwater in some areas of simulated flow paths from base sources.

The preliminary model used here has limitations that should be considered when using these results. Further investigations to improve this evaluation could include additional data collection, such as synoptic water levels with well construction information, and refined simulation with transient flow conditions. 


\section{References Cited}

Bakker, M., Post, V., Langevin, C.D., Hughes, J.D., White, J.T., Starn, J.J. and Fienen, M.N., 2016, Scripting MODFLOW model development using Python and FloPy: Groundwater, v. 54, p. 733-739, accessed October 19, 2018, at https://doi.org/10.1111/gwat.12413.

Bakker, M., Post, V., Langevin, C.D., Hughes, J.D., White, J.T., Starn, J.J., and Fienen, M.N., 2018, FloPy_-Python package for creating, running, and post-processing MODFLOW-based models (ver. 3.2.10): U.S. Geological Survey software release, accessed October 19, 2018, at https://doi.org/10.5066/F7BK19FH.

Barlow, P.M., Cunningham, W.L., Zhai, T., and Gray, M., 2017, The groundwater toolbox-A graphical and mapping interface for analysis of hydrologic data (ver. 1.3.1): U.S. Geological Survey software release, accessed March 13, 2018, at https://doi.org/10.5066/F7R78C9G.

Battelle Memorial Institute, 2016, Final fourth five-year review report for former NAWC Warminster, PA: Prepared under Contract No. N62583-11-D-0515 Task Order No. 0063 for Naval Facilities Engineering Command BRAC Program Management Office East, November 2016, accessed April 19, 2019, at https://www.navfac.navy.mil/content/navfac/en/ products_and_services/ev/products_and_services/env_restoration/administrative_records.html ?fromDate=DD-MON-YYYY\&toDate=DD-MON-

YYYY\&p_instln_id=WARMINSTER_NAWC\&basic $=\&$ title $=\&$ sites $=\&$ author $=\&$ keywords $=$ Berg, T.M., Edmunds, W.E., Geyer, A.R., and others, comps., 1980, Geologic map of

Pennsylvania: Pennsylvania Geological Survey, 4th Series, map 1, 2d ed., scale 1:250,000

Bird, P.H., 1998, Geohydrology and ground-water quality of Warwick Township, Bucks County, Pennsylvania: U.S. Geological Survey Water-Resources Investigations Report 97-4267, 37 p., accessed April 19, 2019, at https://pubs.er.usgs.gov/publication/wri974267.

CDM Federal Programs Corporation, 2003, Annual groundwater monitoring report for May 2003 sampling event, Raymark Superfund Site, Hatboro, Pennsylvania: Report prepared for EPA under contract no. 68-S7-3003, work assignment no. 020-RALR-0378, document control no. 3232-020-RT-OTHR-01880, July 9, 2003, accessed November 21, 2019, at https://semspub.epa.gov/work/03/2073046.pdf.

Conger, R.W., 1997, Evaluation of geophysical logs, phase I, at Willow Grove Naval Air Station, Montgomery County, Pennsylvania: U.S. Geological Survey Open-File Report 97631, 49 p., accessed July 9, 2017, at https://doi.org/10.3133/ofr97631.

Conger, R.W., 1998, Identification of water-bearing zones by the use of geophysical logs and borehole television surveys, collected February to September 1997, at the Former Naval Air Warfare Center, Warminster, Bucks County, Pennsylvania: U.S. Geological Survey Open-File Report 98-86, 26 p., accessed July 9, 2017, at https://pubs.er.usgs.gov/publication/ofr9886.

Conger, R.W., 1999, Evaluation of geophysical logs, phase II, at Willow Grove Naval Air Station Joint Reserve Base, Montgomery County, Pennsylvania: U.S. Geological Survey Open-File Report 99-73, 14 p., accessed July 9, 2017, at https://doi.org/10.3133/ofr9973. Conger, R.W., and Bird, P.H., 1999, Identification of water-bearing fractures by the use of geophysical logs, May to July 1998, former Naval Air Warfare Center, Bucks County, Pennsylvania: U.S. Geological Survey Open-File Report 99-215, 27 p., accessed July 9, 2017, at https://pubs.er.usgs.gov/publication/ofr99215.

Delaware River Basin Commission, 1980, Resolution no. 80-18: Delaware River Basin Commission web page, accessed November 10, 2019, at https://www.state.nj.us/drbc/library/documents/Res1980-18gwpa.pdf. 
Delaware River Basin Commission, 2019, Southeastern Pennsylvania ground water protected area (GWPA) GIS data sets: Delaware River Basin Commission web page, accessed November 1, 2019, at https://www.nj.gov/drbc/programs/project/pr/gwpa-data.html.

Delaware Valley Regional Planning Commission, 2013, Land use in the Delaware Valley, 2010, analytical data report 020: Delaware Valley Regional Planning Commission Publication ADR020, 88 p., accessed November 27, 2019, at https://www.dvrpc.org/Products/ADR020/.

Delaware Valley Regional Planning Commission, 2019, Land use in the Delaware Valley, 2010, digital data: Delaware Valley Regional Planning Commission excel file, accessed November 27, 2019, at https://www.dvrpc.org/Products/ADR020/.

Doherty, J., 2015, Calibration and uncertainty analysis for complex environmental models: Brisbane, Australia, Watermark Numerical Computing, 227 p.

Doherty, J.E., and Hunt, R.J., 2010, Approaches to highly parameterized inversion-A guide to using PEST for groundwater-model calibration: U.S. Geological Survey Scientific Investigations Report 2010-5169, 59 p.

Esri, 2019, ArcGIS desktop release 10.7: Esri, Redlands, Calif., accessed January 3, 2019, at http://desktop.arcgis.com/en/.

Fan, Y., Toran, L., and Schlische, R.W., 2007, Groundwater flow and groundwater-stream interaction in fractured and dipping sedimentary rocks - Insights from numerical models: Water Resources Research, v. 43, no. 1, 13 p., accessed July 9, 2017, at https://agupubs.onlinelibrary.wiley.com/doi/epdf/10.1029/2006WR004864.

Gilmore and Associates, Inc., 2015, Annual hydrogeologic report no. 11, DRBC docket no. D97-16 CP-3, Horsham Water and Sewer Authority, Horsham, Pennsylvania: Report prepared for Horsham Water and Sewer Authority, File no. 15-01135, May 17, 2016, 117 p.

Goode, D.J., 2016, Map visualization of groundwater withdrawals at the sub-basin scale: Hydrogeology Journal, v. 24, p. 1057-1065, accessed July 9, 2017, at https://doi.org/10.1007/s10040-016-1379-x.

Goode, D.J., and Senior, L.A., 2000, Simulation of aquifer tests and ground-water flowpaths at the local scale in fractured shales and sandstones of the Brunswick Group and Lockatong Formation, Lansdale, Montgomery County, Pennsylvania: U.S. Geological Survey Open-File Report 2000-97, 46 p., accessed July 9, 2017, at https://doi.org/10.3133/ofr0097.

Goode, D.J., and Senior, L.A., 2020, MODFLOW 6 and MODPATH 7 model data sets used to evaluate groundwater flow in the vicinity of Horsham and Warminster, Bucks and Montgomery Counties, Pennsylvania-Preliminary simulations for conditions in 1999, 2010, 2013, 2016, and 2017: U.S. Geological Survey data release, https://doi.org/10.5066/P9K36P5S.

Greenman, D.W., 1955, Groundwater resources of Bucks County, Pennsylvania: Pennsylvania Geological Survey, 4th Series, Bulletin W11, 66 p., 1 plate.

H\&S Environmental, Inc., 2012, Semi-annual monitoring report for the fall (November 2011) performance monitoring event for long-term environmental monitoring at Operable Units 1A, 3, and 4 at the former NAWC, Warminster, Pennsylvania: Report prepared for Naval Facilities Engineering Command Mid-Atlantic BRAC Program Management Office Northeast under contract no. N40085-10-D-9409, task order no. 004, June 2012, 234 p.

Hill, M.C., and Tiedeman, C.R., 2007, Effective groundwater model calibration, with analysis of sensitivities, predictions, and uncertainty: New York, Wiley and Sons, 455 p.

Koman Government Solutions LLC, 2018a, Annual monitoring report for the spring (May 2017) performance monitoring event for long-term environmental monitoring at Operable Units 1A, 
3, and 4 at the former NAWC, Warminster, Pennsylvania: Report prepared for Naval Facilities Engineering Command Mid-Atlantic BRAC Program Management Office Northeast under Contract No. N40085-10-D-9409, contract task order no. 004, April 2019, accessed November 9, 2019, at https://www.navfac.navy.mil/niris/MID_ATLANTIC/WARMINSTER_NAWC/N62269_0012 27.pdf.

Koman Government Solutions LLC, 2018b, Former NAWC, Warminster, PA December 2017 groundwater treatment plant report: Report prepared for Naval Facilities Engineering Command Mid-Atlantic BRAC Program Management Office Northeast under Contract No. N40085-10-D-9409, contract task order no. 004, January 2018, 136 p.

Koman Government Solutions LLC, 2018c, Semi-annual monitoring report for the Fall (November 2016) performance monitoring event for long-term environmental monitoring at Operable Units 1A, 3, and 4 at the former NAWC, Warminster, Pennsylvania: Report prepared for Naval Facilities Engineering Command Mid-Atlantic BRAC Program Management Office Northeast under Contract No. N40085-10-D-9409, contract task order no. 004, April 2018, $278 \mathrm{p}$.

Langevin, C.D., Hughes, J.D., Banta, E.R., Niswonger, R.G., Panday, S., and Provost, A.M., 2017, Documentation for the MODFLOW 6 Groundwater Flow Model: U.S. Geological Survey Techniques and Methods, book 6, chap. A55, 197 p., accessed July 9, 2018, at https://doi.org/10.3133/tm6A55.

Langevin, C.D., Hughes, J.D., Banta, E.R., Provost, A.M., Niswonger, R.G., and Panday, S., 2018, MODFLOW 6 Modular Hydrologic Model (ver. 6.0.3): U.S. Geological Survey software release, accessed August 9, 2018, at https://doi.org/10.5066/F76Q1VQV.

Leidos, 2018, Groundwater monitoring report for the perfluorinated compound facility investigation at the Horsham Air Guard Station (111th Attack Wing), Horsham, Pennsylvania: Report prepared for NGB/A4OR Joint Base Andrews, contract W9133L-14-D-0007, delivery order number 0005, August 2018, accessed November 10, 2019, at http://afcec.publicadminrecord.us.af.mil/Search.aspx.

Longwill, S.M., and Wood, C.R., 1965, Ground-water resources of the Brunswick Formation in Montgomery and Berks Counties, Pennsylvania: Pennsylvania Geological Survey, 4th Series, Bulletin W22, 59 p., 1 plate.

Low, D.J, Hippe, D.J., and Yannacci, D., 2002, Geohydrology of southeastern Pennsylvania: U.S. Geological Survey Water-Resources Investigation Report 2002-4166, 347 p. [Also available at https://doi.org/10.3133/wri004166.]

Lyttle, P.T., and Epstein, J.B., 1987, Geologic map of the Newark 1 degree x 2 degrees quadrangle, New Jersey, Pennsylvania and New York: U.S. Geological Survey Miscellaneous Investigations Map I-1715, scale 1:250,000. [Also available at https://doi.org/10.3133/i1715; Georeferenced version of Map I-1715 available at https://ngmdb.usgs.gov/Prodesc/proddesc 9892.htm.]

Montgomery County Planning Commission, 1994, 1993 Status report sewage treatment facilities in Montgomery County: Norristown, Pennsylvania.

National Oceanic and Atmospheric Administration, 2018a, Climate at a glance, county time series, Bucks County, Pennsylvania: National Centers for Environmental Information web page, accessed December 22, 2018, at https://www.ncdc.noaa.gov/cag/. 
National Oceanic and Atmospheric Administration, 2018b, Climate at a glance, county time series, Montgomery County, Pennsylvania: National Centers for Environmental Information web page, accessed December 22, 2018, at https://www.ncdc.noaa.gov/cag/.

Naval Facilities Engineering Command, 2018, Final second five-year review for former Naval Air Station Joint Reserve Base Willow Grove Horsham, Pennsylvania: Naval Facilities Engineering Command BRAC Program Management Office East, September 2018, accessed April 19, 2019, at https://www.navfac.navy.mil/niris/MID ATLANTIC/WILLOW_GROVE_NAS/N00158_000760.pdf.

Newport, T.G., 1971, Ground-water resources of Montgomery County, Pennsylvania: Pennsylvania Geological Survey, 4th Series, Bulletin W29, 83 p., 2 plates.

Penn State Institutes of Energy and Environment, 2015, PAMAP Program 3m county mosaic digital elevation model: Pennsylvania Spatial Data Access web page, accessed May 2016 from ftp://ftp.pasda.psu.edu/pub/pasda/pamap/LidarMosaics/CountyMosaics/county_DEM_3M/.

Pennsylvania Department of Environmental Protection, 2019a, Wastewater reports, eDMR data: Pennsylvania Department of Environmental Protection Bureau of Clean Water web page, accessed March 2019 at https://www.dep.pa.gov/Business/Water/CleanWater/Pages/Wastewater-Reports.aspx.

Pennsylvania Department of Environmental Protection, 2019b, Water reports, water use reports, water quantity report by source: Pennsylvania Department of Environmental Protection web page, accessed November 2019 at https://www.dep.pa.gov/DataandTools/Reports/Pages/Water.aspx.

Pennsylvania Department of Environmental Protection, 2019c, Water reports, water use reports, water use report by facility: Pennsylvania Department of Environmental Protection web page, accessed November 2019 at https://www.dep.pa.gov/DataandTools/Reports/Pages/Water.aspx.

Pennsylvania Department of Conservation \& Natural Resources Bureau of Topographic and Geological Survey, 2018, Pennsylvania Groundwater Information System: Pennsylvania Department of Conservation \& Natural Resources web page, accessed November 2018 at https://www.dcnr.pa.gov/Conservation/Water/Groundwater/PAGroundwaterInformationSyste $\mathrm{m} /$ Pages/default.aspx.

Pollock, D.W., 2016, User guide for MODPATH version 7-A particle-tracking model for MODFLOW: U.S. Geological Survey Open-File Report 2016-1086, 35 p., accessed July 9, 2018, at https://doi.org/10.3133/ofr20161086.

Pollock, D.W., 2017, MODPATH v7.2.01-A particle-tracking model for MODFLOW: U.S. Geological Survey software release, accessed November 2017 at https://doi.org/10.5066/F70P0X5X.

Provost, A.M., Langevin, C.D., and Hughes, J.D., 2017, Documentation for the "XT3D" option in the Node Property Flow (NPF) Package of MODFLOW 6: U.S. Geological Survey Techniques and Methods, book 6, chap. A56, 40 p., accessed July 9, 2018, at https://doi.org/10.3133/tm6A56.

Resolution Consultants, 2019, Remedial investigation report, per- and polyfluoralkyl substances investigation activities NASJRB Willow Grove, PA: Report prepared for Naval Facilities Engineering Command (NAVFAC) Mid-Atlantic, contract N62470-11-D-8013, Final version 1, September 20, 2019, accessed November 10, 2019, at https://www.navfac.navy.mil/products_and_services/ev/products_and_services/env_restoration /administrative_records.html?fromDate $=$ DD-MON-YYYY\&toDate=DD-MONYYYY\&p_instln_id=WILLOW_GROVE_NAS\&basic=\&title=\&sites=\&author=\&keywords $=$. 
Rima, D.R., Meisler, H., and Longwill, S., 1962, Geology and hydrology of the Stockton Formation in southeastern Pennsylvania: Pennsylvania Geological Survey, 4th Series, Bulletin W14, 110 p., 4 plates.

Rowland, C.J., 1997, Altitude and configuration of the potentiometric surface in Warwick Township, Bucks County, Pennsylvania, September 1994 through May 1995: U.S. Geological Survey Open-File Report 97-554, 1 plate, accessed July 9, 2017, at https://doi.org/10.3133/ofr97554.

Schlische, R., 1992, Structural and stratigraphic development of the Newark extensional basin, eastern North America-Evidence for the growth of the basin and its bounding structures: Geological Society of America Bulletin, v. 104, p. 1246-1263.

Schreffler, C.L., 1996, Water-use analysis program for the Neshaminy Creek basin, Bucks and Montgomery counties, Pennsylvania: U.S. Geological Survey Water-Resources Investigations Report 96-4127, $85 \mathrm{p}$.

Senior, L.A., and Goode, D.J., 1999, Ground-water system, estimation of aquifer hydraulic properties, and effects of pumping on ground-water flow in Triassic sedimentary rocks in and near Lansdale, Pennsylvania: U.S. Geological Survey Water-Resources Investigations Report 99-4228, $112 \mathrm{p}$.

Senior, L.A., and Goode, D.J., 2013, Investigations of groundwater system and simulation of regional groundwater flow for North Penn Area 7 Superfund site, Montgomery County, Pennsylvania (ver. 1.1, April 2015): U.S. Geological Survey Scientific Investigations Report 2013-5045, 95 p., accessed July 9, 2017, at https:/pubs.usgs.gov/sir/2013/5045/.

Senior, L.A., and Goode, D.J., 2017, Effects of changes in pumping on regional groundwaterflow paths, 2005 and 2010, and areas contributing recharge to discharging wells, 1990-2010, in the vicinity of North Penn Area 7 Superfund site, Montgomery County, Pennsylvania: U.S. Geological Survey Scientific Investigations Report 2017-5014, 36 p., accessed July 9, 2017, at https://doi.org/10.3133/sir20175014.

Senior, L.A., Ludlow, R.A., and Zarr, L.F, 2020, Groundwater levels, groundwater withdrawals, and point-source discharges to streams in the vicinity of Willow Grove and Warminster, Bucks and Montgomery Counties, Pennsylvania, for selected years during 1999-2017: U.S.

Geological Survey data release, https://doi.org/10.5066/P9ZGEI67.

Senior, L.A., and Ruddy, A.J., 2004, Altitude and configuration of the water-level surface in Mesozoic sedimentary rocks at and near the North Penn Area 7 Superfund Site, Upper Gwynedd Township, Montgomery County, Pennsylvania, December 4-6, 2000: U.S. Geological Survey Open-File Report 2004-1006, 1 sheet, 1:24,000, accessed July 9, 2017, at https://pubs.er.usgs.gov/publication/ofr041006.

Sevon, W.D., 2000, comp., Physiographic provinces of Pennsylvania: Pennsylvania Geological Survey Map 13, scale 1:2,000,000, 4th ed., accessed January 31, 2019, at http://www.docs.denr.pa.gov/cs/groups/public/documents/document/denr_016202.pdf.

Sloto, R.A., 1997, Results of borehole geophysical logging and aquifer-isolation tests conducted in the John Wagner and Sons, Inc former production well, Ivyland, Pennsylvania: U.S. Geological Survey Water-Resources Investigations Report 1997-4095, 18 p., accessed July 9, 2017, at https://pubs.er.usgs.gov/publication/wri974095.

Sloto, R.A., 1998, Results of borehole geophysical logging and hydraulic tests conducted in Area D supply wells, former U.S. Naval Air Warfare Center, Warminster, Pennsylvania: U.S. Geological Survey Water-Resources Investigations Report 98-4129, 47 p. 
Sloto, R.A., 2002, Hydrogeological investigation at Site 5, Willow Grove Naval Air Station/Joint Reserve Base, Horsham Township, Montgomery County, Pennsylvania: U.S. Geological Survey Water-Resources Investigations Report 2001-4263, 37 p., accessed July 9, 2017, at https://pubs.er.usgs.gov/publication/wri014263.

Sloto, R.A., 2007, Interpretation of borehole geophysical logs, aquifer-isolation tests, and waterquality data for sites 1, 3, and 5 at the Willow Grove Naval Air Station/Joint Reserve Base, Horsham Township, Montgomery County, Pennsylvania-2005: U.S. Geological Survey Scientific Investigations Report 2006-5243, 74 p., accessed July 9, 2017, at https://doi.org/10.3133/sir20065243.

Sloto, R.A., 2008, Interpretation of borehole geophysical logs at Area C, former Naval Air Warfare Center, Warminster Township, Bucks County, Pennsylvania, 2007: U.S. Geological Survey Open-File Report 2008-1207, 20 p., accessed July 9, 2017, at https://doi.org/10.3133/ofr20081207.

Sloto, R.A., 2010, Changes in groundwater flow and volatile organic compound concentrations at the Fischer and Porter Superfund Site, Warminster Township, Bucks County, Pennsylvania, 1993-2009: U.S. Geological Survey Scientific Investigations Report 2010-5054, 115 p.

Sloto, R.A., and Buxton, D.E., 2007, Estimated ground-water availability in the Delaware River Basin, 1997-2000 (ver. 1.1, May 2007): U.S. Geological Survey Scientific Investigations Report 2006-5125, $67 \mathrm{p}$.

Sloto, R.A., Conger, R.W., and Grazul, K.E., 1998, Geohydrology and distribution of volatile organic compounds in ground water in the Casey Village area, Bucks County, Pennsylvania: U.S. Geological Survey Water-Resources Investigations Report 1998-4010, 81 p., accessed July 9, 2017, at https://pubs.er.usgs.gov/publication/wri984010.

Sloto, R.A., and Crouse, M.Y., 1986, HYSEP - A computer program for streamflow hydrograph separation and analysis: U.S. Geological Survey Water-Resources Investigations Report 864040, 46 p., accessed March 28, 2019, at https://pubs.er.usgs.gov/publication/wri964047.

Sloto, R.A., and Davis, D.K., 1982, Effect of urbanization on the water resources of Warminster Township, Bucks County, Pennsylvania: U.S. Geological Survey Water-Resources Investigations Report 82-4010, 78 p., accessed March 28, 2019, at https://pubs.er.usgs.gov/publication/wri824020.

Sloto, R.A., Goode, D.J., and Frasch, S.M., 2002, Interpretation of borehole geophysical logs, aquifer-isolation tests, and water quality, supply wells 1 and 2, Willow Grove Naval Air Station/Joint Reserve Base, Horsham Township, Montgomery County, Pennsylvania: U.S. Geological Survey Water-Resources Investigations Report 2001-4264, 64 p., accessed July 9, 2017, at https://pubs.er.usgs.gov/publication/wri014264.

Sloto, R.A., Goode, D.J., and Way, J.H., 2001, Altitude and configuration of the regional potentiometric surface, Willow Grove Naval Air Station/Joint Reserve Base and vicinity, Horsham Township, Montgomery County, Pennsylvania, October 7-8, 1999: U.S. Geological Survey Open-File Report 2001-0149, 13 p., accessed July 9, 2017, at https://pubs.er.usgs.gov/publication/ofr01149.

Sloto, R.A., and Grazul, K.E., 1995, Altitude and configuration of the potentiometric surface, Casey Village, Warminster and Upper Southampton Townships, Bucks County, Pennsylvania, August 3, 1995: U.S. Geological Survey Open-File Report 95-717, 2 maps on one sheet, accessed July 9, 2017, at https://doi.org/10.3133/ofr95717.

Sloto, R.A., Macchioroli, P., and Towle, M.T., 1996, Geohydrology of the Stockton Formation and cross-contamination through open boreholes, Hatboro Borough and Warminster 
Township, Pennsylvania: U.S. Geological Survey Water-Resources Investigations Report 864047, 49 p., 2 plates, accessed March 28, 2019, at https://pubs.er.usgs.gov/publication/wri964047.

Sloto, R.A., and Schreffler, C.L., 1994, Hydrogeology and ground-water quality of northern Bucks County, Pennsylvania: U.S. Geological Survey Water-Resources Investigations Report 94-4109, 85 p., 1 plate. [Also available at https://doi.org/10.3133/wri944109.]

Solley, W.B., Pierce, R.R., and Perlman, H.A., 1998, Estimated use of water in the United States in 1995: U.S. Geological Survey Circular 1200, 71 p., accessed November 1, 2019, at https://doi.org/10.3133/cir1200.

Tetra Tech, 2014, Evaluation of potential source of perfluorinated compounds, former Naval Air Warfare Center Warminster, Pennsylvania: Report prepared for Naval Facilities Engineering Command Mid-Atlantic, Norfolk, Virginia, contract number N62470-08-D-1001, contract task orderWE23, report N62269.AR.001000 NAWC WARMINSTER 5090.3a, November 2014, accessed November 11, 2019, at https://www.navfac.navy.mil/niris/MID ATLANTIC/WARMINSTER_NAWC/N62269_001000.pdf.

Turner-Peterson, C.E., and Smoot, J.P., 1985, New thoughts on facies relationships in the Triassic Stockton and Lockatong Formations, Pennsylvania and New Jersey, in Gilpin, G.R., Jr., and Froehlich, A.J., eds., Proceedings of the second U.S. Geological Survey workshop on the early Mesozoic basins of the Eastern United States: U.S. Geological Survey Circular 946, p. 10-17, accessed July 9, 2017, at https://doi.org/10.3133/cir946.

U.S. Census Bureau, 2019, Quick facts: U.S. Census Bureau web page, accessed July 9, 2019, at https:/www.census.gov/quickfacts/fact/table/northamptontownshipbuckscountypennsylvania,h atboroboroughpennsylvania, warringtontownshipbuckscountypennsylvania, warwicktownshipb uckscountypennsylvania, warminstertownshipbuckscountypennsylvania,horshamtownshipmont gomerycountypennsylvania/PST045218.

U.S. Environmental Protection Agency, 2006, Pilot region-based optimization program for fundlead sites in EPA Region 3, Site optimization tracker: Raymark, Hatboro, Pennsylvania: EPA report 542-R-06-006f, December 2006, 53 p.

U.S. Environmental Protection Agency, 2012, Third unregulated contaminant monitoring rule: U.S. Environmental Protection Agency web page, accessed January 31, 2019, at https://www.epa.gov/dwucmr/third-unregulated-contaminant-monitoring-rule.

U.S. Environmental Protection Agency, 2014, Peer review of health effects documents for PFOA and PFOS: U.S. Environmental Protection Agency, Office of Water, EPA-820-F-14-004, 2 p., accessed April 10, 2015, at http://water.epa.gov/drink/standards/upload/Peer-Review-ofHealth-Effects-Documents-for-PFOA-and-PFOS-Factsheet-February-2014.pdf.

U.S. Environmental Protection Agency, 2016, Fact sheet PFOA \& PFOS drinking water health advisories: U.S. Environmental Protection Agency web page, EPA 800-F-16-003, 5 p., accessed March 28, 2018, at https://www.epa.gov/sites/production/files/201606/documents/drinkingwaterhealthadvisories_pfoa_pfos_updated_5.31.16.pdf.

U.S. Geological Survey, 1998, Southeastern Pennsylvania ground water protected area: U.S. Geological Survey Open-File Report 98-571, 1 CD, accessed August 12, 2019, at https://pubs.er.usgs.gov/publication/ofr98571.

U.S. Geological Survey, 2005, USGS National Hydrography Dataset (NHD)-High-resolution flowline features: U.S. Geological Survey National Hydrography Dataset, accessed June 3, 2009, at https://www.pasda.psu.edu/uci/DataSummary.aspx?dataset=364. 
U.S. Geological Survey, 2016, USGS National Hydrography Dataset (NHD) downloadable data collection: U.S. Geological Survey National Hydrography Dataset, accessed November 7, 2019, at https://www.usgs.gov/core-science-systems/ngp/tnm-delivery/.

U.S. Geological Survey, 2018, USGS water data for the Nation: U.S. Geological Survey National Water Information System database, accessed September 16, 2018, at https://doi.org/10.5066/F7P55KJN.

U.S. Navy, 2019a, Naval Facilities Engineering Command Former Naval Air Station Joint Reserve Base Willow Grove documents: Naval Facilities Engineering Command web page, accessed November 5, 2019, at

https://www.bracpmo.navy.mil/brac_bases/northeast/reserve_base_willow_grove/documents.h tml.

U.S. Navy, 2019b, Naval Facilities Engineering Command Former Naval Air Warfare Center Warminster documents: Naval Facilities Engineering Command web page, accessed November 5, 2019, at https://www.bracpmo.navy.mil/brac_bases/northeast/former_warfare_center_warminster/docu ments.html.

Welter, D.E., White, J.T., Hunt, R.J., and Doherty, J.E., 2015, Approaches in highly parameterized inversion-PEST++ Version 3, a Parameter ESTimation and uncertainty analysis software suite optimized for large environmental models: U.S. Geological Survey Techniques and Methods, book 7, section C12, 54 p.

White, J., Welter, D., and Doherty, J., 2019, PEST++ Version 4: 170 p., accessed November 26, 2019, at http://www.pesthomepage.org/PEST_and_PESTPP.php.

White, K.E., and Sloto, R.A., 1990, Base-flow frequency characteristics of selected Pennsylvania streams: U.S. Geological Survey Water-Resources Investigations Report 90-4160, 67 p.

Winston, R.B., 2019, ModelMuse version 4-A graphical user interface for MODFLOW 6: U.S. Geological Survey Scientific Investigations Report 2019-5036, 10 p.

Winston, R.B., and Goode, D.J., 2017, Visualization of groundwater withdrawals: U.S. Geological Survey Open-File Report 2017-1137, 8 p. 


\section{Appendix 1. Annual Base Flow as Determined from Measured Streamflow at Selected Gages and Estimated for Missing Streamflow Records During 2010-2015}

Groundwater base-flow data were compiled from records at selected stream gages near Willow Grove and Warminster, Pennsylvania (U.S. Geological Survey, 2018). Base flow was estimated using daily mean streamflow values and HYSEP local-minimum hydrograph separation method in U.S. Geological Survey (USGS) Groundwater Toolbox (Barlow and others, 2017). The annual average base flow was computed from the average of monthly average base-flow values (tables 1.1-1.3).

Missing values for stream flow at several stream gages were estimated by regression (table 1.4, fig. 1.1). USGS continuous gages with missing data were: 01467031 Pennypack Creek at Horsham; 01467036 Pennypack tributary at Hatboro; 01467039 Pennypack Creek at Willow Grove; and 014670413 Pennypack Creek at Bethayres. Regressions with 2010 monthly base flow (in cubic feet per second) at Pine Road gage was selected to fill missing monthly data for January-March 2010 at three Pennypack Creek gages: Horsham, Hatboro, Willow Grove. Regression with 2015 monthly base flow (in cubic feet per second) at Pine Road gage was selected to fill missing monthly data for October-December 2015 at four Pennypack Creek gages: Horsham, Hatboro, Willow Grove, Bethayres. Regressions with instantaneous values at Iron Works gage and daily values at Horsham gage (table 1.5, figs. 1.2 and 1.3) were used to estimate monthly average base flow at Iron Works gage from monthly average base flow at Horsham gage (table 1.6).

Regression was used to estimate missing data for four gages and, for Iron Works Creek, to estimate average baseflow values. Regressions with 2010 monthly base flow (in cubic feet per second) at Pine Road gage was selected to fill missing monthly data for January-March 2010 at three Pennypack Creek gages: Horsham, Hatboro, Willow Grove. Regressions with 2015 monthly baseflow (in cubic feet per second) at Pine Road gage was selected to fill missing monthly data for October-December 2015 at four Pennypack Creek gages: Horsham, Hatboro, Willow Grove, Bethayres. See tables 1.2 and 1.4 for more information about gages.

\section{References}

Barlow, P.M., Cunningham, W.L., Zhai, T., and Gray, M., 2017, The groundwater toolbox-A graphical and mapping interface for analysis of hydrologic data (ver. 1.3.1): U.S. Geological Survey software release, accessed March 13, 2018, at https://doi.org/10.5066/F7R78C9G.

U.S. Geological Survey, 2018, USGS water data for the Nation: U.S. Geological Survey National Water Information System database, accessed September 16, 2018, at https://doi.org/10.5066/F7P55KJN. 
Table1.1.Annual base flow (calendar year January-December) as determined by hydrograph separation methods for daily streamflow values at U.S. Geological Survey stream gage 01464907 Little Neshaminy Creek at Valley Road, 1999-2017, drainage area 26.8 square miles. HYSEP local-minimum hydrograph separation method in USGS Groundwater Toolbox (Barlow and others, 2017).

[CFS, annual average flow, in cubic feet per second; in, annual average flow per drainage area, in inches; BFP, Base-flow percentage (ratio of base flow to streamflow multiplied by 100); --, not applicable]

\begin{tabular}{cccccrrrr}
\hline \multirow{2}{*}{ Year count } & Calendar & \multicolumn{2}{c}{ Streamflow } & \multicolumn{2}{c}{ Base flow } & \multicolumn{2}{c}{ Runoff } & \multicolumn{1}{c}{ BFP } \\
& year & CFS & \multicolumn{1}{c}{ in } & \multicolumn{1}{c}{ CFS } & \multicolumn{1}{c}{ in } & \multicolumn{1}{c}{ CFS } & in & BFP.55 \\
\hline 1 & 1999 & 42.8 & 21.68 & 10.95 & 5.55 & 31.85 & 16.13 & 25.6 \\
2 & 2000 & 39.2 & 19.92 & 15.75 & 8.00 & 23.48 & 11.93 & 40.1 \\
3 & 2001 & 46.0 & 23.28 & 14.49 & 7.34 & 31.46 & 15.94 & 31.5 \\
4 & 2002 & 28.1 & 14.22 & 10.81 & 5.47 & 17.26 & 8.74 & 38.5 \\
5 & 2003 & 75.8 & 38.41 & 26.96 & 13.65 & 48.88 & 24.76 & 35.5 \\
6 & 2004 & 60.1 & 30.55 & 22.99 & 11.68 & 37.16 & 18.87 & 38.2 \\
7 & 2005 & 54.3 & 27.49 & 18.65 & 9.45 & 35.63 & 18.04 & 34.4 \\
8 & 2006 & 66.4 & 33.62 & 23.04 & 11.67 & 43.34 & 21.95 & 34.7 \\
9 & 2007 & 51.6 & 26.14 & 16.99 & 8.61 & 34.61 & 17.53 & 32.9 \\
10 & 2008 & 46.6 & 23.68 & 18.06 & 9.17 & 28.56 & 14.51 & 38.7 \\
11 & 2009 & 60.0 & 30.40 & 23.29 & 11.79 & 36.74 & 18.61 & 38.8 \\
12 & 2010 & 46.8 & 23.71 & 15.94 & 8.07 & 30.87 & 15.64 & 34.1 \\
13 & 2011 & 91.4 & 46.29 & 25.15 & 12.74 & 66.24 & 33.55 & 27.5 \\
14 & 2012 & 30.7 & 15.59 & 13.23 & 6.72 & 17.47 & 8.87 & 43.1 \\
15 & 2013 & 49.7 & 25.20 & 17.12 & 8.67 & 32.62 & 16.52 & 34.4 \\
16 & 2014 & 52.6 & 26.63 & 18.81 & 9.53 & 33.77 & 17.11 & 35.8 \\
17 & 2015 & 40.1 & 20.34 & 16.44 & 8.33 & 23.71 & 12.01 & 41.0 \\
18 & 2016 & 33.7 & 17.14 & 15.14 & 7.69 & 18.61 & 9.45 & 44.9 \\
19 & 2017 & 37.8 & 19.15 & 16.45 & 8.33 & 21.35 & 10.81 & 43.5 \\
\hline \multirow{2}{*}{ Minimum } & -- & 28.1 & 14.22 & 10.81 & 5.47 & 17.26 & 8.74 & 25.6 \\
Maximum & -- & 91.4 & 46.29 & 26.96 & 13.65 & 66.24 & 33.55 & 44.9 \\
Median & -- & 46.8 & 23.71 & 16.99 & 8.61 & 31.85 & 16.13 & 35.8 \\
Average & -- & 50.2 & 25.44 & 17.91 & 9.08 & 32.30 & 16.37 & 36.5 \\
\hline
\end{tabular}


Table 1.2. Annual base flow (calendar year January December) as determined by hydrograph separation methods for available complete years of daily streamflow values at U.S. Geological Survey stream gages on Pennypack Creek, 2008-16. HYSEP local-minimum hydrograph separation method in USGS Groundwater Toolbox (Barlow and others, 2017).

[CFS, annual average flow, in cubic feet per second; in, annual average flow per unit area, in inches; BFP, Baseflow percentage (ratio of base flow to streamflow multiplied by 100)]

\begin{tabular}{|c|c|c|c|c|c|c|c|c|}
\hline \multirow[b]{2}{*}{ Year count } & \multirow[b]{2}{*}{ Date } & \multicolumn{2}{|c|}{ Streamflow } & \multicolumn{2}{|c|}{ Base flow } & \multicolumn{2}{|c|}{ Runoff } & \multirow[b]{2}{*}{ BFP } \\
\hline & & CFS & in & CFS & in & CFS & in & \\
\hline \multicolumn{9}{|c|}{ Station 01467031 Pennypack Creek at Horsham; drainage area 3.5 square miles } \\
\hline 1 & 2011 & 10.4 & 40.48 & 4.52 & 17.63 & 5.86 & 22.85 & 43.6 \\
\hline 2 & 2012 & 2.7 & 10.50 & 1.36 & 5.30 & 1.33 & 5.20 & 50.5 \\
\hline 3 & 2013 & 4.8 & 18.88 & 2.36 & 9.20 & 2.48 & 9.67 & 48.8 \\
\hline 4 & 2014 & 5.6 & 21.82 & 2.41 & 9.39 & 3.19 & 12.43 & 43.0 \\
\hline \multicolumn{9}{|c|}{ Station 01467036 Pennypack tributary at Hatboro; drainage area 4.4 square miles } \\
\hline 1 & 2011 & 11.4 & 35.41 & 4.43 & 13.80 & 6.94 & 21.61 & 39.0 \\
\hline 2 & 2012 & 3.5 & 10.78 & 1.17 & 3.65 & 2.28 & 7.12 & 33.9 \\
\hline 3 & 2013 & 5.6 & 17.55 & 1.95 & 6.08 & 3.68 & 11.47 & 34.7 \\
\hline 4 & 2014 & 5.1 & 16.00 & 1.89 & 5.88 & 3.25 & 10.12 & 36.8 \\
\hline \multicolumn{9}{|c|}{ Station 01467039 Pennypack Creek at Willow Grove; drainage area 22.2 square miles } \\
\hline 1 & 2011 & 72.5 & 44.33 & 35.20 & 21.52 & 37.30 & 22.81 & 48.6 \\
\hline 2 & 2012 & 32.6 & 19.96 & 18.30 & 11.22 & 14.25 & 8.74 & 56.2 \\
\hline 3 & 2013 & 41.8 & 25.56 & 21.73 & 13.29 & 20.07 & 12.27 & 52.0 \\
\hline 4 & 2014 & 45.3 & 27.68 & 23.61 & 14.43 & 21.67 & 13.25 & 52.1 \\
\hline \multicolumn{9}{|c|}{ Station 014670413 Pennypack Creek at Beth Ayres; drainage area 35.3 square miles } \\
\hline 1 & 2010 & 71.1 & 27.33 & 37.54 & 14.44 & 33.53 & 12.89 & 52.8 \\
\hline 2 & 2011 & 111.2 & 42.77 & 43.36 & 16.68 & 67.86 & 26.10 & 39.0 \\
\hline 3 & 2012 & 49.9 & 19.24 & 29.20 & 11.26 & 20.71 & 7.98 & 58.5 \\
\hline 4 & 2013 & 61.8 & 23.78 & 33.51 & 12.89 & 28.33 & 10.89 & 54.2 \\
\hline 5 & 2014 & 68.5 & 26.32 & 37.28 & 14.33 & 31.18 & 11.99 & 54.5 \\
\hline \multicolumn{9}{|c|}{ Station 01467042 PennypackCreek at Pine Road; drainage area 37.9 square miles } \\
\hline 1 & 2008 & 61.2 & 22.00 & 32.16 & 11.55 & 29.08 & 10.44 & 52.5 \\
\hline 2 & 2009 & 80.7 & 28.91 & 38.34 & 13.73 & 42.37 & 15.18 & 47.5 \\
\hline 3 & 2010 & 79.8 & 28.57 & 41.03 & 14.70 & 38.75 & 13.88 & 51.4 \\
\hline 4 & 2011 & 126.3 & 45.22 & 50.98 & 18.26 & 75.28 & 26.96 & 40.4 \\
\hline 5 & 2012 & 53.0 & 19.04 & 31.34 & 11.26 & 21.68 & 7.78 & 59.1 \\
\hline 6 & 2013 & 63.7 & 22.81 & 35.29 & 12.64 & 28.39 & 10.17 & 55.4 \\
\hline 7 & 2014 & 72.2 & 25.85 & 39.12 & 14.01 & 33.06 & 11.84 & 54.2 \\
\hline 8 & 2015 & 53.5 & 19.17 & 28.95 & 10.37 & 24.56 & 8.80 & 54.1 \\
\hline 9 & 2016 & 42.2 & 15.14 & 25.28 & 9.06 & 16.94 & 6.08 & 59.9 \\
\hline
\end{tabular}


Table 1.3. Annual base flow (calendar year January-December) as determined by hydrograph separation methods for daily streamflow values at U.S. Geological Survey stream gage 01473900 , Wissahickon Creek at Fort Washington, 2001-16, drainage area 40.9 square miles. HYSEP local-minimum hydrograph separation method in USGS Groundwater Toolbox (Barlow and others, 2017).

[CFS, annual average flow, in cubic feet per second; in, annual average flow per unit area, in inches; BFP, Base-flow percentage (ratio of base flow to streamflow multiplied by 100)]

\begin{tabular}{ccrrrrrrr}
\hline \multirow{2}{*}{ Year count } & Calendar & \multicolumn{2}{c}{ Streamflow } & \multicolumn{2}{c}{ Base flow } & \multicolumn{2}{c}{ Runoff } & \\
& year & \multicolumn{1}{c}{ CFS } & \multicolumn{1}{c}{ in } & \multicolumn{1}{c}{ CFS } & \multicolumn{1}{c}{ in } & CFS & in & BFP \\
\hline 1 & 2001 & 69.1 & 22.93 & 34.25 & 11.37 & 34.86 & 11.57 & 49.6 \\
2 & 2002 & 50.3 & 16.68 & 24.24 & 8.04 & 26.03 & 8.64 & 48.2 \\
3 & 2003 & 115.8 & 38.43 & 48.85 & 16.21 & 66.94 & 22.22 & 42.2 \\
4 & 2004 & 97.1 & 32.30 & 43.50 & 14.48 & 53.56 & 17.83 & 44.8 \\
5 & 2005 & 76.8 & 25.49 & 38.36 & 12.73 & 38.44 & 12.76 & 49.9 \\
6 & 2006 & 93.5 & 31.04 & 40.64 & 13.49 & 52.89 & 17.55 & 43.5 \\
7 & 2007 & 81.9 & 27.18 & 34.88 & 11.58 & 47.02 & 15.61 & 42.6 \\
8 & 2008 & 66.5 & 22.14 & 28.59 & 9.51 & 37.95 & 12.63 & 43.0 \\
9 & 2009 & 97.9 & 32.50 & 42.26 & 14.03 & 55.65 & 18.47 & 43.2 \\
10 & 2010 & 83.5 & 27.73 & 37.82 & 12.55 & 45.72 & 15.17 & 45.3 \\
11 & 2011 & 130.9 & 43.43 & 49.62 & 16.47 & 81.24 & 26.96 & 37.9 \\
12 & 2012 & 58.4 & 19.43 & 30.87 & 10.28 & 27.49 & 9.15 & 52.9 \\
13 & 2013 & 78.2 & 25.95 & 38.83 & 12.89 & 39.36 & 13.06 & 49.7 \\
14 & 2014 & 87.8 & 29.13 & 41.78 & 13.87 & 45.99 & 15.26 & 47.6 \\
15 & 2015 & 57.8 & 19.17 & 29.16 & 9.68 & 28.59 & 9.49 & 50.5 \\
16 & 2016 & 48.0 & 15.96 & 27.23 & 9.06 & 20.74 & 6.90 & 56.8 \\
\hline
\end{tabular}


Table 1.4. Regressions with monthly base flow at U.S. Geological Survey gage 01467042 Pennypack Creek at Pine Road, at Philadelphia, Pennysylvania to fill missing monthly data for January-March 2010 and October-December 2015 and estimate annual average 2010 and 2015 base flow at four Pennypack Creek USGS continuous gages, 2010-15. Base flow determined using daily streamflow values and HYSEP local-minimum hydrograph separation method in USGS Groundwater Toolbox (Barlow and others, 2017). Estimated values in bold italics. Annual average base flow computed from average of monthly average base-flow values. Station headings shaded in colors shown for sites in regression plots (fig. 1.1).

[M-YY, month-year; DA, drainage area; $\mathrm{mi}^{2}$, square miles; CFS, in cubic feet per second; BF, base flow; BFP, Base-flow percentage (ratio of base flow to streamflow multiplied by 100)]

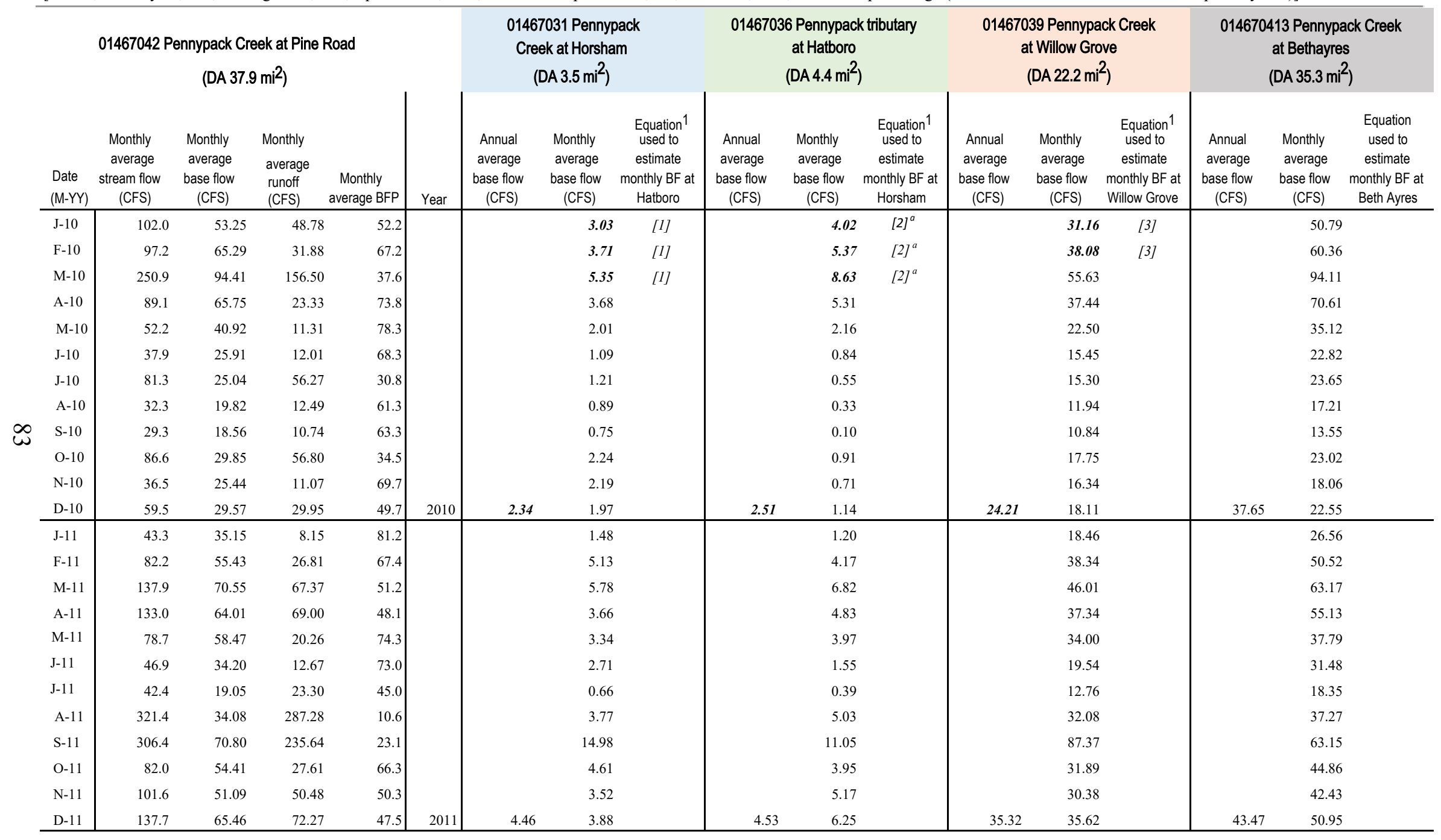

${ }^{1}$ Equations relating base flow at gage with missing values (y) to base flow at Pennypack Creek at Pine Road (x): [4] y $=0.0753 \mathrm{x}-0.7773 ;$ [5] y $=0.0925 \mathrm{x}-0.8041 ;[6] \mathrm{y}=0.6264 \mathrm{x}+0.5025 ;$ [7] $\mathrm{y}=0.9206 \mathrm{x}-0.6814$.

${ }^{\mathrm{a}}$ Regression equation for period April 2010 - August 2011 at Horsham; regression equation for period April 2010 - December 2010 of $\mathrm{y}=0.1097 \mathrm{x}-2.0833$ results in estimated monthly average base flow of

$3.76 \mathrm{cfs}$ for January 2010, $5.08 \mathrm{cfs}$ for February 2010, $8.27 \mathrm{cfs}$ for March 2010, with estimated annual average of $2.43 \mathrm{cfs}$ at Horsham (3 percent smaller than estimated value of $2.51 \mathrm{cfs}$ used for model input). 
Table 1.4. Regressions with monthly base flow at U.S. Geological Survey gage 01467042 Pennypack Creek at Pine Road, at Philadelphia, Pennysylvania to fill missing monthly data for January-March 2010 and October-December 2015 and estimate annual average 2010 and 2015 base flow at four Pennypack Creek USGS continuous gages, 2010-15. Base flow determined using daily streamflow values and HYSEP local-minimum hydrograph separation method in USGS Groundwater Toolbox (Barlow and others, 2017). Estimated values in bold italics. Annual average base flow computed from average of monthly average base-flow values.Station headings shaded in colors shown for sites in regression plots (fig. 1.1).--Continued

[M-YY, month-year; DA, drainage area; mi $^{2}$, square miles; CFS, cubic feet per second; BF, base flow; BFP, Base-flow percentage (ratio of base flow to streamflow multiplied by 100)]

\begin{tabular}{|c|c|c|c|c|c|c|c|c|c|c|c|c|c|c|c|c|c|}
\hline \multirow[b]{2}{*}{$\begin{array}{l}\text { Date } \\
(\mathrm{M}-\mathrm{YY}) \\
\end{array}$} & \multicolumn{4}{|c|}{01467042 Pennypack Creek at Pine Road } & \multicolumn{4}{|c|}{$\begin{array}{l}01467031 \text { Pennypack } \\
\text { Creek at Horsham } \\
\left(\text { DA } 3.5 \mathrm{mi}^{2}\right)\end{array}$} & \multicolumn{3}{|c|}{$\begin{array}{c}01467036 \text { Pennypack tributary } \\
\text { at Hatboro } \\
\left(\text { DA } 4.4 \mathrm{mi}^{2} \text { ) }\right.\end{array}$} & \multicolumn{3}{|c|}{$\begin{array}{c}01467039 \text { Pennypack Creek } \\
\text { at Willow Grove } \\
\left(\text { DA } 22.2 \mathrm{mi}^{2} \text { ) }\right.\end{array}$} & \multicolumn{3}{|c|}{$\begin{array}{c}014670413 \text { Pennypack Creek } \\
\text { at Bethayres } \\
\text { (DA } 35.3 \mathrm{mi}^{2} \text { ) }\end{array}$} \\
\hline & $\begin{array}{l}\text { Monthly } \\
\text { average } \\
\text { stream flow } \\
\text { (CFS) }\end{array}$ & $\begin{array}{l}\text { Monthly } \\
\text { average } \\
\text { base flow } \\
\text { (CFS) } \\
\end{array}$ & $\begin{array}{l}\text { Monthly } \\
\text { average } \\
\text { runoff } \\
\text { (CFS) } \\
\end{array}$ & $\begin{array}{c}\text { Monthly } \\
\text { average BFP }\end{array}$ & Year & $\begin{array}{c}\text { Annual } \\
\text { average } \\
\text { base flow } \\
\text { (CFS) } \\
\end{array}$ & $\begin{array}{l}\text { Monthly } \\
\text { average } \\
\text { base flow } \\
\text { (CFS) } \\
\end{array}$ & $\begin{array}{c}\text { Equation } \\
\text { used to } \\
\text { estimate } \\
\text { monthly BF at } \\
\text { Hatboro } \\
\end{array}$ & $\begin{array}{c}\text { Annual } \\
\text { average } \\
\text { base flow } \\
\text { (CFS) } \\
\end{array}$ & $\begin{array}{l}\text { Monthly } \\
\text { average } \\
\text { base flow } \\
\text { (CFS) } \\
\end{array}$ & $\begin{array}{l}\text { Equation } \\
\text { used to } \\
\text { estimate } \\
\text { monthly BF at } \\
\text { Horsham } \\
\end{array}$ & $\begin{array}{c}\text { Annual } \\
\text { average } \\
\text { base flow } \\
\text { (CFS) } \\
\end{array}$ & $\begin{array}{l}\text { Monthly } \\
\text { average } \\
\text { base flow } \\
\text { (CFS) }\end{array}$ & $\begin{array}{l}\text { Equation } \\
\text { used to } \\
\text { estimate } \\
\text { monthly BF at } \\
\text { Willow Grove } \\
\end{array}$ & $\begin{array}{c}\text { Annual } \\
\text { average } \\
\text { base flow } \\
\text { (CFS) } \\
\end{array}$ & $\begin{array}{l}\text { Monthly } \\
\text { average } \\
\text { base flow } \\
\text { (CFS) } \\
\end{array}$ & $\begin{array}{c}\text { Equation } \\
\text { used to } \\
\text { estimate } \\
\text { monthly BF at } \\
\text { Beth Ayres } \\
\end{array}$ \\
\hline $\mathrm{J}-12$ & 92.8 & 59.53 & 33.28 & 64.1 & & \multicolumn{3}{|c|}{2.82} & \multicolumn{3}{|c|}{4.66} & \multicolumn{3}{|c|}{33.67} & \multicolumn{3}{|c|}{48.37} \\
\hline $\mathrm{F}-12$ & 54.8 & 49.48 & 5.35 & 90.2 & & \multicolumn{3}{|c|}{1.97} & \multicolumn{3}{|c|}{2.45} & \multicolumn{3}{|c|}{27.16} & \multicolumn{3}{|c|}{37.54} \\
\hline $\mathrm{M}-12$ & 45.5 & 36.96 & 8.58 & 81.2 & & \multicolumn{3}{|c|}{1.52} & \multicolumn{3}{|c|}{1.76} & \multicolumn{3}{|c|}{22.22} & \multicolumn{3}{|c|}{33.74} \\
\hline A-12 & 49.6 & 28.76 & 20.82 & 58.0 & & \multicolumn{3}{|c|}{1.09} & \multicolumn{3}{|c|}{1.21} & \multicolumn{3}{|c|}{16.19} & \multicolumn{3}{|c|}{30.61} \\
\hline $\mathrm{M}-12$ & 62.7 & 35.22 & 27.44 & 56.2 & & \multicolumn{3}{|c|}{1.48} & \multicolumn{3}{|c|}{1.72} & \multicolumn{3}{|c|}{19.73} & \multicolumn{3}{|c|}{39.52} \\
\hline $\mathrm{J}-12$ & 37.8 & 30.10 & 7.65 & 79.7 & & \multicolumn{3}{|c|}{0.90} & & 1.17 & & & 16.20 & & & 29.64 & \\
\hline $\mathrm{J}-12$ & 39.3 & 21.37 & 17.91 & 54.4 & & & 0.53 & & & 0.33 & & & 11.21 & & & 20.04 & \\
\hline A-12 & 48.9 & 22.25 & 26.67 & 45.5 & & & 1.01 & & & 0.37 & & & 14.28 & & & 21.05 & \\
\hline S-12 & 57.6 & 23.42 & 34.22 & 40.6 & & & 0.58 & & & 0.36 & & & 14.60 & & & 22.15 & \\
\hline $\mathrm{O}-12$ & 48.6 & 21.27 & 27.37 & 43.7 & & & 0.44 & & & 0.33 & & & 12.11 & & & 20.45 & \\
\hline $\mathrm{N}-12$ & 25.1 & 21.49 & 3.64 & 85.5 & & & 0.32 & & & 0.64 & & & 13.95 & & & 20.36 & \\
\hline D-12 & 72.2 & 26.74 & 45.47 & 37.0 & 2012 & 1.17 & 1.38 & & 1.36 & 1.28 & & 18.32 & 18.50 & & 29.21 & 27.05 & \\
\hline $\mathrm{J}-13$ & 65.9 & 37.26 & 28.62 & 56.6 & & & 1.68 & & & 1.94 & & & 21.05 & & & 37.87 & \\
\hline $\mathrm{F}-13$ & 51.9 & 41.07 & 10.86 & 79.1 & & & 2.45 & & & 2.78 & & & 25.72 & & & 37.13 & \\
\hline $\mathrm{M}-13$ & 63.0 & 43.13 & 19.85 & 68.5 & & & 2.55 & & & 3.47 & & & 27.95 & & & 40.69 & \\
\hline A-13 & 52.8 & 38.48 & 14.35 & 72.8 & & & 2.19 & & & 3.07 & & & 23.42 & & & 35.07 & \\
\hline $\mathrm{M}-13$ & 52.3 & 35.92 & 16.43 & 68.6 & & & 1.38 & & & 2.64 & & & 22.03 & & & 33.20 & \\
\hline $\mathrm{J}-13$ & 136.5 & 50.94 & 85.59 & 37.3 & & & 3.44 & & & 4.18 & & & 31.64 & & & 49.16 & \\
\hline $\mathrm{J}-13$ & 62.0 & 34.23 & 27.75 & 55.2 & & & 2.46 & & & 2.24 & & & 21.78 & & & 35.74 & \\
\hline $\mathrm{A}-13$ & 76.0 & 31.32 & 44.73 & 41.2 & & & 1.91 & & & 1.97 & & & 18.30 & & & 30.60 & \\
\hline S-13 & 35.5 & 25.00 & 10.46 & 70.5 & & & 1.03 & & & 1.43 & & & 14.21 & & & 21.69 & \\
\hline O-13 & 41.1 & 23.77 & 17.29 & 57.9 & & & 0.82 & & & 1.00 & & & 14.25 & & & 20.05 & \\
\hline $\mathrm{N}-13$ & 52.4 & 21.47 & 30.91 & 41.0 & & & 0.77 & & & 0.84 & & & 12.99 & & & 19.41 & \\
\hline D-13 & 74.3 & 41.25 & 33.08 & 55.5 & 2013 & 1.96 & 2.79 & & 2.36 & 2.79 & & 21.76 & 27.73 & & 33.52 & 41.61 & \\
\hline
\end{tabular}


Table1.4. Regressions with monthly base flow at U.S. Geological Survey gage 01467042 Pennypack Creek at Pine Road, at Philadelphia, Pennysylvania to fill missing monthly data for January-March 2010 and October-December 2015 and estimate annual average 2010 and 2015 base flow at four Pennypack Creek USGS continuous gages, 2010-15. Base flow determined using daily streamflow values and HYSEP local-minimum hydrograph separation method in USGS Groundwater Toolbox (Barlow and others, 2017). Estimated values in bold italics. Annual average base flow computed from average of monthly average base-flow values. Station headings shaded in colors shown for sites in regression plots (fig. 1.1).--Continued

[M-YY, month-year; DA, drainage area; $\mathrm{mi}^{2}$, square miles; CFS, in cubic feet per second; BF, base flow; BFP, Base-Flow Percentage (ratio of base flow to streamflow multiplied by 100)]

\begin{tabular}{|c|c|c|c|c|c|c|c|c|c|c|c|c|c|c|c|c|c|}
\hline \multirow[b]{2}{*}{$\begin{array}{l}\text { Date } \\
\text { (M-YY) }\end{array}$} & \multicolumn{4}{|c|}{$\begin{array}{l}01467042 \text { Pennypack Creek at Pine Road } \\
\text { (DA } 37.9 \mathrm{mi2} \text { ) }\end{array}$} & \multicolumn{4}{|c|}{$\begin{array}{l}01467031 \text { Pennypack } \\
\text { Creek at Horsham } \\
\left(\text { DA } 3.5 \mathrm{mi}^{2} \text { ) }\right.\end{array}$} & \multicolumn{3}{|c|}{$\begin{array}{c}01467036 \text { Pennypack tributary } \\
\text { at Hatboro } \\
\left(\mathrm{DA} 4.4 \mathrm{mi}^{2}\right)\end{array}$} & \multicolumn{3}{|c|}{$\begin{array}{c}\text { 01467039 Pennypack Creek } \\
\text { at Willow Grove } \\
\text { (DA } 22.2 \mathrm{mi}^{2} \text { ) }\end{array}$} & \multicolumn{3}{|c|}{$\begin{array}{c}014670413 \text { Pennypack Creek } \\
\text { at Bethayres } \\
\text { (DA } 35.3 \mathrm{mi}^{2} \text { ) }\end{array}$} \\
\hline & $\begin{array}{l}\text { Monthly } \\
\text { average } \\
\text { stream flow } \\
\text { (CFS) }\end{array}$ & $\begin{array}{c}\text { Monthly } \\
\text { average } \\
\text { base flow } \\
\text { (CFS) } \\
\end{array}$ & $\begin{array}{l}\text { Monthly } \\
\text { average } \\
\text { runoff } \\
\text { (CFS) } \\
\end{array}$ & $\begin{array}{c}\text { Monthly } \\
\text { average BFP }\end{array}$ & Year & $\begin{array}{c}\text { Annual } \\
\text { average } \\
\text { base flow } \\
\text { (CFS) } \\
\end{array}$ & $\begin{array}{l}\text { Monthly } \\
\text { average } \\
\text { base flow } \\
\text { (CFS) }\end{array}$ & $\begin{array}{l}\text { Equation }{ }^{1} \\
\text { used to } \\
\text { estimate } \\
\text { monthly BF at } \\
\text { Hatboro }\end{array}$ & $\begin{array}{c}\text { Annual } \\
\text { average } \\
\text { base flow } \\
\text { (CFS) } \\
\end{array}$ & $\begin{array}{l}\text { Monthly } \\
\text { average } \\
\text { base flow } \\
\text { (CFS) } \\
\end{array}$ & $\begin{array}{l}\text { Equation } 1 \\
\text { used to } \\
\text { estimate } \\
\text { monthly BF at } \\
\text { Horsham } \\
\end{array}$ & $\begin{array}{c}\text { Annual } \\
\text { average } \\
\text { base flow } \\
\text { (CFS) } \\
\end{array}$ & $\begin{array}{c}\text { Monthly } \\
\text { average } \\
\text { base flow } \\
\text { (CFS) } \\
\end{array}$ & 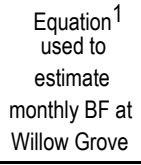 & $\begin{array}{c}\text { Annual } \\
\text { average } \\
\text { base flow } \\
\text { (CFS) } \\
\end{array}$ & $\begin{array}{l}\text { Monthly } \\
\text { average } \\
\text { base flow } \\
\text { (CFS) }\end{array}$ & $\begin{array}{c}\text { Equation } 1 \\
\text { used to } \\
\text { estimate } \\
\text { monthly BF at } \\
\text { Beth Ayres } \\
\end{array}$ \\
\hline $\mathrm{J}-14$ & 79.4 & 53.52 & 25.90 & 67.4 & \multirow[b]{12}{*}{2014} & \multicolumn{3}{|c|}{3.54} & \multicolumn{3}{|c|}{3.72} & \multicolumn{3}{|c|}{33.57} & \multicolumn{3}{|c|}{52.75} \\
\hline F-14 & 112.3 & 52.10 & 60.22 & 46.4 & & \multicolumn{3}{|c|}{3.26} & \multicolumn{3}{|c|}{4.15} & \multicolumn{3}{|c|}{38.36} & \multicolumn{3}{|c|}{47.98} \\
\hline M-14 & 109.1 & 56.41 & 52.72 & 51.7 & & \multicolumn{3}{|c|}{3.68} & \multicolumn{3}{|c|}{5.71} & \multicolumn{3}{|c|}{38.58} & \multicolumn{3}{|c|}{50.07} \\
\hline A-14 & 148.4 & 64.51 & 83.93 & 43.5 & & \multicolumn{3}{|c|}{3.86} & \multicolumn{3}{|c|}{4.29} & \multicolumn{3}{|c|}{37.59} & \multicolumn{3}{|c|}{64.21} \\
\hline M-14 & 138.0 & 66.91 & 71.04 & 48.5 & & \multicolumn{3}{|c|}{3.18} & \multicolumn{3}{|c|}{3.54} & \multicolumn{3}{|c|}{33.88} & \multicolumn{3}{|c|}{59.97} \\
\hline $\mathrm{J}-14$ & 69.2 & 43.86 & 25.35 & 63.4 & & & 1.07 & & & 2.55 & & & 22.38 & & & 45.26 & \\
\hline $\mathrm{J}-14$ & 47.6 & 28.49 & 19.13 & 59.8 & & & 0.45 & & & 1.31 & & & 14.49 & & & 27.82 & \\
\hline A-14 & 29.3 & 21.34 & 7.95 & 72.9 & & & 0.23 & & & 0.65 & & & 11.70 & & & 19.82 & \\
\hline S-14 & 19.6 & 17.12 & 2.48 & 87.3 & & & 0.21 & & & 0.39 & & & 9.63 & & & 16.13 & \\
\hline O-14 & 27.9 & 18.28 & 9.61 & 65.5 & & & 0.40 & & & 0.51 & & & 9.89 & & & 17.53 & \\
\hline $\mathrm{N}-14$ & 41.1 & 21.51 & 19.61 & 52.3 & & & 1.07 & & & 0.81 & & & 12.77 & & & 20.44 & \\
\hline D-14 & 47.7 & 26.40 & 21.34 & 55.3 & & 1.90 & 1.80 & & 2.42 & 1.36 & & 23.69 & 21.46 & & 37.35 & 26.27 & \\
\hline $\mathrm{J}-15$ & 71.5 & 32.33 & 39.17 & 45.2 & & & 1.87 & & & 1.78 & & & 22.18 & & & 29.19 & \\
\hline F-15 & 55.6 & 40.54 & 15.07 & 72.9 & & & 2.24 & & & 2.35 & & & 20.59 & & & 32.62 & \\
\hline M-15 & 121.7 & 60.96 & 60.76 & 50.1 & & & 4.41 & & & 5.42 & & & 42.83 & & & 58.75 & \\
\hline A- 15 & 70.2 & 43.57 & 26.60 & 62.1 & & & 2.09 & & & 3.20 & & & 27.02 & & & 39.76 & \\
\hline M-15 & 34.6 & 32.32 & 2.30 & 93.4 & & & 1.10 & & & 2.06 & & & 17.78 & & & 26.14 & \\
\hline $\mathrm{J}-15$ & 50.9 & 24.92 & 25.94 & 49.0 & & & 0.48 & & & 1.35 & & & 15.41 & & & 20.70 & \\
\hline $\mathrm{J}-15$ & 35.3 & 19.66 & 15.69 & 55.6 & & & 0.38 & & & 1.14 & & & 13.71 & & & 19.19 & \\
\hline A-15 & 37.9 & 13.89 & 24.06 & 36.6 & & & 0.57 & & & 0.78 & & & 11.81 & & & 14.30 & \\
\hline S-15 & 35.3 & 14.35 & 20.95 & 40.7 & & & 1.15 & & & 0.83 & & & 10.17 & & & 13.32 & \\
\hline O-15 & 35.9 & 17.91 & 17.95 & 49.9 & & & 0.57 & [4] & & 0.85 & [5] & & 11.72 & {$[6]$} & & 15.81 & [7] \\
\hline $\mathrm{N}-15$ & 32.2 & 16.57 & 15.60 & 51.5 & & & 0.47 & [4] & & 0.73 & [5] & & 10.88 & {$[6]$} & & 14.57 & [7] \\
\hline D-15 & 60.5 & 30.99 & 29.47 & 51.3 & 2015 & 1.41 & 1.56 & {$[4]$} & 1.88 & 2.06 & {$[5]$} & 18.67 & 19.91 & {$[6]$} & 26.02 & 27.85 & {$[7]$} \\
\hline
\end{tabular}

\footnotetext{
${ }^{1}$ Equations relating base flow at gage with missing values (y) to base flow at Pennypack Creek at Pine Road (x): [4] y = 0.0753x $-0.7773 ;[5] \mathrm{y}=0.0925 \mathrm{x}-0.8041 ;[6] \mathrm{y}=0.6264 \mathrm{x}+0.5025 ;[7] \mathrm{y}=0.9206 \mathrm{x}-0.6814$.
} 
Table 1.5. Instantaneous discharge (flow) measurements at U.S. Geological Survey gage 01465460 Iron Works Creek at Richboro and daily mean flow at gage 01467031 Pennypack Creek at Horsham, Pennsylvania, 2010-15 (U.S. Geological Survey, 2018).

[CFS, cubic feet per second; EST, eastern standard time; EDT, eastern daylight time]

\begin{tabular}{rcccc}
\multicolumn{1}{c}{$\begin{array}{c}\text { Measurement date } \\
\text { and time }\end{array}$} & $\begin{array}{c}\text { Time zone } \\
\text { code }\end{array}$ & $\begin{array}{c}\text { Gage height, in } \\
\text { feet }\end{array}$ & $\begin{array}{c}\text { Iron Works } \\
\text { instantaneous } \\
\text { discharge, in CFS }\end{array}$ & $\begin{array}{c}\text { Horsham mean } \\
\text { daily flow, in CFS }\end{array}$ \\
\hline \multicolumn{1}{c}{ 5/18/2010 13:25 } & EDT & 1.83 & 9.3 & 8.32 \\
$8 / 17 / 201013: 58$ & EDT & 1.54 & 0.37 & 1.52 \\
$10 / 5 / 201013: 05$ & EDT & 1.66 & 2.38 & 5.06 \\
$2 / 7 / 201114: 30$ & EST & 1.75 & 4.54 & 6.69 \\
$5 / 11 / 201112: 18$ & EDT & 1.70 & 2.77 & 2.2 \\
$10 / 6 / 201114: 10$ & EDT & 1.73 & 4.15 & 4.26 \\
$2 / 6 / 201210: 43$ & EST & 1.72 & 3.78 & 3.39 \\
$5 / 16 / 201210: 04$ & EDT & 1.69 & 2.88 & 8.08 \\
$8 / 27 / 201212: 51$ & EDT & 1.84 & 7.76 & 1.61 \\
$10 / 10 / 201212: 43$ & EDT & 1.62 & 1.12 & 0.34 \\
$2 / 4 / 201316: 07$ & EST & 1.72 & 4.73 & 2.98 \\
$6 / 26 / 201312: 35$ & EDT & 1.70 & 3.48 & 4.56 \\
$10 / 25 / 201311: 07$ & EDT & 1.61 & 1.12 & 1.01 \\
$11 / 19 / 201314: 49$ & EST & 1.59 & 0.71 & 0.66 \\
$4 / 7 / 201413: 21$ & EDT & 1.78 & 4.43 & 6.64 \\
$8 / 29 / 201413: 45$ & EDT & 1.60 & 0.22 & 0.45 \\
$10 / 28 / 201414: 19$ & EDT & 1.60 & 0.62 & 0.73 \\
$1 / 23 / 201512: 51$ & EST & 1.71 & 3.93 & 2.93 \\
$1 / 23 / 201513: 29$ & EST & 1.71 & 5.08 & 2.93 \\
$1 / 23 / 201513: 47$ & EST & 1.71 & 5.52 & 2.93 \\
$5 / 7 / 201513: 04$ & EDT & 1.68 & 3.04 & 3.06 \\
$9 / 23 / 201511: 58$ & EDT & 1.55 & 0.47 & 0.86 \\
\hline
\end{tabular}


Table 1.6. Estimated base flow at U.S. Geological Survey (USGS) gage 01465460 Iron Works Creek at Richboro, Pennsylvania from relation to base flow at USGS gage 01467031 Pennypack Creek at Horsham, Pennsylvania, 2010-15. Base flow determined using daily streamflow values and HYSEP local-minimum hydrograph separation method in USGS Groundwater Toolbox (Barlow and others, 2017). Estimated values in italics. Annual average base flow computed from average of monthly average base-flow values. [DA, drainage area; $\mathrm{mi}^{2}$, square miles; CFS, cubic feet per second; BF, base flow; BFP, Base-flow percentage (ratio of base flow to streamflow multiplied by 100)]

\begin{tabular}{|c|c|c|c|c|c|c|c|c|c|c|c|}
\hline \multirow[b]{2}{*}{$\begin{array}{l}\text { Date } \\
\text { (M-YY) }\end{array}$} & \multicolumn{4}{|c|}{$\begin{array}{l}01467042 \text { Pennypack Creek at Pine Road } \\
\text { (DA } 37.9 \mathrm{mi}^{2} \text { ) }\end{array}$} & \multirow[b]{2}{*}{ Year } & \multicolumn{3}{|c|}{$\begin{array}{c}01467031 \text { Pennypack Creek at } \\
\text { Horsham } \\
\text { (DA } 3.5 \mathrm{mi}^{2} \text { ) }\end{array}$} & \multicolumn{3}{|c|}{$\begin{array}{c}01465460 \text { Iron Works Creek at } \\
\text { Richboro } \\
\text { (DA } 3.69 \mathrm{mi}^{2} \text { ) }\end{array}$} \\
\hline & $\begin{array}{l}\text { Monthly } \\
\text { average } \\
\text { stream flow } \\
\text { (CFS) }\end{array}$ & $\begin{array}{l}\text { Monthly } \\
\text { average } \\
\text { base flow } \\
\text { (CFS) } \\
\end{array}$ & $\begin{array}{l}\text { Monthly } \\
\text { average } \\
\text { runoff } \\
\text { (CFS) } \\
\end{array}$ & $\begin{array}{c}\text { Monthly } \\
\text { average BFP }\end{array}$ & & $\begin{array}{c}\text { Annual } \\
\text { average } \\
\text { base flow } \\
\text { (CFS) }\end{array}$ & $\begin{array}{l}\text { Monthly } \\
\text { average } \\
\text { base flow } \\
\text { (CFS) }\end{array}$ & $\begin{array}{c}\text { Equation } 1 \text { used } \\
\text { to estimate } \\
\text { monthly BF at } \\
\text { Hatboro } \\
\end{array}$ & $\begin{array}{c}\text { Annual } \\
\text { average } \\
\text { base flow } \\
\text { (CFS) } \\
\end{array}$ & $\begin{array}{l}\text { Estimated } \\
\text { monthly } \\
\text { average } \\
\text { base flow } \\
\text { (CFS) }\end{array}$ & $\begin{array}{l}\text { Equation }{ }^{1} \text { used } \\
\text { to estimate } \\
\text { monthly BF at } \\
\text { Iron Works }\end{array}$ \\
\hline $\mathrm{J}-10$ & 102.0 & 53.25 & 48.78 & 52.2 & \multirow[b]{12}{*}{2010} & \multirow{3}{*}{\multicolumn{3}{|c|}{$\begin{array}{ll}3.03 & {[1]} \\
3.71 & {[1]} \\
5.35 & {[1]}\end{array}$}} & & 2.85 & {$[8]$} \\
\hline F-10 & 97.2 & 65.29 & 31.88 & 67.2 & & & & & & 3.38 & {$[8]$} \\
\hline M-10 & 250.9 & 94.41 & 156.50 & 37.6 & & & & & & 4.62 & {$[8]$} \\
\hline A-10 & 89.1 & 65.75 & 23.33 & 73.8 & & \multicolumn{3}{|c|}{3.68} & & 3.36 & {$[8]$} \\
\hline M-10 & 52.2 & 40.92 & 11.31 & 78.3 & & \multicolumn{3}{|c|}{2.01} & & 2.01 & {$[8]$} \\
\hline $\mathrm{J}-10$ & 37.9 & 25.91 & 12.01 & 68.3 & & \multicolumn{3}{|c|}{1.09} & & 1.19 & {$[8]$} \\
\hline $\mathrm{J}-10$ & 81.3 & 25.04 & 56.27 & 30.8 & & \multicolumn{3}{|c|}{1.21} & & 1.30 & {$[8]$} \\
\hline A-10 & 32.3 & 19.82 & 12.49 & 61.3 & & \multicolumn{3}{|c|}{0.89} & & 1.00 & [8] \\
\hline S-10 & 29.3 & 18.56 & 10.74 & 63.3 & & \multicolumn{3}{|c|}{0.75} & & 0.87 & {$[8]$} \\
\hline O-10 & 86.6 & 29.85 & 56.80 & 34.5 & & \multicolumn{3}{|c|}{2.24} & & 2.20 & {$[8]$} \\
\hline $\mathrm{N}-10$ & 36.5 & 25.44 & 11.07 & 69.7 & & \multicolumn{3}{|c|}{2.19} & & 2.16 & {$[8]$} \\
\hline D-10 & 59.5 & 29.57 & 29.95 & 49.7 & & \multicolumn{3}{|c|}{1.97} & 2.24 & 1.97 & {$[8]$} \\
\hline $\mathrm{J}-11$ & 43.3 & 35.15 & 8.15 & 81.2 & & \multicolumn{3}{|c|}{1.48} & & 1.55 & {$[8]$} \\
\hline F-11 & 82.2 & 55.43 & 26.81 & 67.4 & & \multicolumn{3}{|c|}{5.13} & & 4.46 & {$[8]$} \\
\hline M-11 & 137.9 & 70.55 & 67.37 & 51.2 & & \multicolumn{3}{|c|}{5.78} & & 4.93 & {$[8]$} \\
\hline A-11 & 133.0 & 64.01 & 69.00 & 48.1 & & \multicolumn{3}{|c|}{3.66} & & 3.34 & {$[8]$} \\
\hline M-11 & 78.7 & 58.47 & 20.26 & 74.3 & & \multicolumn{3}{|c|}{3.34} & & 3.09 & {$[8]$} \\
\hline $\mathrm{J}-11$ & 46.9 & 34.20 & 12.67 & 73.0 & & \multicolumn{3}{|c|}{2.71} & & 2.59 & {$[8]$} \\
\hline $\mathrm{J}-11$ & 42.4 & 19.05 & 23.30 & 45.0 & & \multicolumn{3}{|c|}{0.66} & & 0.78 & {$[8]$} \\
\hline A-11 & 321.4 & 34.08 & 287.28 & 10.6 & & & 3.77 & & & 3.43 & {$[8]$} \\
\hline S-11 & 306.4 & 70.80 & 235.64 & 23.1 & & & 14.98 & & & 11.09 & {$[8]$} \\
\hline O-11 & 82.0 & 54.41 & 27.61 & 66.3 & & & 4.61 & & & 4.07 & {$[8]$} \\
\hline $\mathrm{N}-11$ & 101.6 & 51.09 & 50.48 & 50.3 & & & 3.52 & & & 3.23 & {$[8]$} \\
\hline D-11 & 137.7 & 65.46 & 72.27 & 47.5 & 2011 & 4.46 & 3.88 & & 3.84 & 3.51 & {$[8]$} \\
\hline $\mathrm{J}-12$ & 92.8 & 59.53 & 33.28 & 64.1 & & & 2.82 & & & 2.68 & {$[8]$} \\
\hline F-12 & 54.8 & 49.48 & 5.35 & 90.2 & & & 1.97 & & & 1.97 & {$[8]$} \\
\hline M-12 & 45.5 & 36.96 & 8.58 & 81.2 & & & 1.52 & & & 1.58 & {$[8]$} \\
\hline A-12 & 49.6 & 28.76 & 20.82 & 58.0 & & & 1.09 & & & 1.19 & {$[8]$} \\
\hline M-12 & 62.7 & 35.22 & 27.44 & 56.2 & & & 1.48 & & & 1.55 & {$[8]$} \\
\hline $\mathrm{J}-12$ & 37.8 & 30.10 & 7.65 & 79.7 & & & 0.90 & & & 1.01 & {$[8]$} \\
\hline $\mathrm{J}-12$ & 39.3 & 21.37 & 17.91 & 54.4 & & & 0.53 & & & 0.65 & {$[8]$} \\
\hline A-12 & 48.9 & 22.25 & 26.67 & 45.5 & & & 1.01 & & & 1.12 & {$[8]$} \\
\hline S-12 & 57.6 & 23.42 & 34.22 & 40.6 & & & 0.58 & & & 0.70 & {$[8]$} \\
\hline $\mathrm{O}-12$ & 48.6 & 21.27 & 27.37 & 43.7 & & & 0.44 & & & 0.55 & {$[8]$} \\
\hline $\mathrm{N}-12$ & 25.1 & 21.49 & 3.64 & 85.5 & & & 0.32 & & & 0.42 & {$[8]$} \\
\hline D-12 & 72.2 & 26.74 & 45.47 & 37.0 & 2012 & 1.17 & 1.38 & & 1.24 & 1.46 & {$[8]$} \\
\hline
\end{tabular}

${ }^{1}$ See table 3.4 for Equations [1] and [4] relating base flow at gage with missing values (x) to base flow at Pennypack Creek at Pine Road. Equation [8] estimating monthly base flow at Iron Works gage (y) using monthly base flow at Pennypack Creek at Horsham (x):

$\mathrm{y}=1.1084 \mathrm{x}^{0.8509}$, where equation based on regression of instantaneous flow at Iron Works (IW) with Horsham daily values (dv) in CFS; for $\mathrm{v}=\mathrm{dv}$ Horsham, $\mathrm{w}=\mathrm{IW}$ instantaneous flow, $\mathrm{w}=1.1084 \mathrm{v}^{0.8509}, \mathrm{R}^{2}=0.5863$; see table 1.5 and figure 1.2 . 
Table 1.6. Estimated base flow at U.S. Geological Survey (USGS) gage 01465460 Iron Works Creek at Richboro, Pennsylvania from relation to base flow at USGS gage 01467031 Pennypack Creek at Horsham, Pennsylvania, 2010-15. Base flow determined using daily streamflow values and HYSEP local-minimum hydrograph separation method in USGS Groundwater Toolbox (Barlow and others, 2017). Estimated values in italics. Annual average base flow computed from average of monthly average base-flow values. --Continued

[DA, drainage area; $\mathrm{mi}^{2}$, square miles; CFS, cubic feet per second; BF, base flow; BFP, Base-flow percentage (ratio of base flow to streamflow multiplied by 100)]

\begin{tabular}{|c|c|c|c|c|c|c|c|c|c|c|c|}
\hline \multirow[b]{2}{*}{$\begin{array}{l}\text { Date } \\
\text { (M-YY) }\end{array}$} & \multicolumn{4}{|c|}{$\begin{array}{l}01467042 \text { Pennypack Creek at Pine Road } \\
\text { (DA } 37.9 \mathrm{mi}^{2} \text { ) }\end{array}$} & \multirow[b]{2}{*}{ Year } & \multicolumn{3}{|c|}{$\begin{array}{c}01467031 \text { Pennypack Creek at } \\
\text { Horsham } \\
\text { (DA } 3.5 \mathrm{mi}^{2} \text { ) }\end{array}$} & \multicolumn{3}{|c|}{$\begin{array}{l}01465460 \text { Iron Works Creek at } \\
\text { Richboro } \\
\text { (DA } 3.69 \mathrm{mi}^{2} \text { ) }\end{array}$} \\
\hline & $\begin{array}{c}\text { Monthly } \\
\text { average } \\
\text { stream flow } \\
\text { (CFS) }\end{array}$ & $\begin{array}{l}\text { Monthly } \\
\text { average } \\
\text { base flow } \\
\text { (CFS) }\end{array}$ & $\begin{array}{l}\text { Monthly } \\
\text { average } \\
\text { runoff } \\
\text { (CFS) } \\
\end{array}$ & $\begin{array}{c}\text { Monthly } \\
\text { average BFP }\end{array}$ & & $\begin{array}{c}\text { Annual } \\
\text { average } \\
\text { base flow } \\
\text { (CFS) }\end{array}$ & $\begin{array}{l}\text { Monthly } \\
\text { average } \\
\text { base flow } \\
\text { (CFS) }\end{array}$ & $\begin{array}{c}\text { Equation } 1 \text { used } \\
\text { to estimate } \\
\text { monthly BF at } \\
\text { Hatboro }\end{array}$ & $\begin{array}{l}\text { Annual } \\
\text { average } \\
\text { base flow } \\
\text { (CFS) } \\
\end{array}$ & $\begin{array}{c}\text { Estimated } \\
\text { monthly } \\
\text { average } \\
\text { base flow } \\
\text { (CFS) }\end{array}$ & $\begin{array}{l}\text { Equation }{ }^{1} \text { used } \\
\text { to estimate } \\
\text { monthly BF at } \\
\text { Iron Works }\end{array}$ \\
\hline $\mathrm{J}-13$ & 65.9 & 37.26 & 28.62 & 56.6 & \multirow[b]{12}{*}{2013} & \multicolumn{3}{|c|}{1.68} & & 1.72 & {$[8]$} \\
\hline F-13 & 51.9 & 41.07 & 10.86 & 79.1 & & \multicolumn{3}{|c|}{2.45} & & 2.38 & {$[8]$} \\
\hline M-13 & 63.0 & 43.13 & 19.85 & 68.5 & & \multicolumn{3}{|c|}{2.55} & & 2.46 & {$[8]$} \\
\hline A-13 & 52.8 & 38.48 & 14.35 & 72.8 & & \multicolumn{3}{|c|}{2.19} & & 2.16 & {$[8]$} \\
\hline M-13 & 52.3 & 35.92 & 16.43 & 68.6 & & \multicolumn{3}{|c|}{1.38} & & 1.46 & {$[8]$} \\
\hline $\mathrm{J}-13$ & 136.5 & 50.94 & 85.59 & 37.3 & & \multicolumn{3}{|c|}{3.44} & & 3.17 & {$[8]$} \\
\hline $\mathrm{J}-13$ & 62.0 & 34.23 & 27.75 & 55.2 & & \multicolumn{3}{|c|}{2.46} & & 2.38 & {$[8]$} \\
\hline A-13 & 76.0 & 31.32 & 44.73 & 41.2 & & \multicolumn{3}{|c|}{1.91} & & 1.92 & {$[8]$} \\
\hline S-13 & 35.5 & 25.00 & 10.46 & 70.5 & & \multicolumn{3}{|c|}{1.03} & & 1.14 & {$[8]$} \\
\hline O-13 & 41.1 & 23.77 & 17.29 & 57.9 & & \multicolumn{3}{|c|}{0.82} & & 0.94 & {$[8]$} \\
\hline $\mathrm{N}-13$ & 52.4 & 21.47 & 30.91 & 41.0 & & \multicolumn{3}{|c|}{0.77} & & 0.89 & {$[8]$} \\
\hline D-13 & 74.3 & 41.25 & 33.08 & 55.5 & & \multicolumn{3}{|c|}{2.79} & 1.94 & 2.65 & {$[8]$} \\
\hline $\mathrm{J}-14$ & 79.4 & 53.52 & 25.90 & 67.4 & & \multicolumn{3}{|c|}{3.54} & & 3.25 & {$[8]$} \\
\hline F-14 & 112.3 & 52.10 & 60.22 & 46.4 & & \multicolumn{3}{|c|}{3.26} & & 3.03 & {$[8]$} \\
\hline M-14 & 109.1 & 56.41 & 52.72 & 51.7 & & \multicolumn{3}{|c|}{3.68} & & 3.36 & {$[8]$} \\
\hline A-14 & 148.4 & 64.51 & 83.93 & 43.5 & & \multicolumn{3}{|c|}{3.86} & & 3.50 & {$[8]$} \\
\hline M-14 & 138.0 & 66.91 & 71.04 & 48.5 & & \multicolumn{3}{|c|}{3.18} & & 2.97 & {$[8]$} \\
\hline $\mathrm{J}-14$ & 69.2 & 43.86 & 25.35 & 63.4 & & & 1.07 & & & 1.17 & {$[8]$} \\
\hline $\mathrm{J}-14$ & 47.6 & 28.49 & 19.13 & 59.8 & & & 0.45 & & & 0.56 & {$[8]$} \\
\hline A-14 & 29.3 & 21.34 & 7.95 & 72.9 & & & 0.23 & & & 0.32 & {$[8]$} \\
\hline S-14 & 19.6 & 17.12 & 2.48 & 87.3 & & & 0.21 & & & 0.29 & {$[8]$} \\
\hline O-14 & 27.9 & 18.28 & 9.61 & 65.5 & & & 0.40 & & & 0.51 & {$[8]$} \\
\hline $\mathrm{N}-14$ & 41.1 & 21.51 & 19.61 & 52.3 & & & 1.07 & & & 1.17 & {$[8]$} \\
\hline D-14 & 47.7 & 26.40 & 21.34 & 55.3 & 2014 & 1.90 & 1.80 & & 1.83 & 1.83 & {$[8]$} \\
\hline J-15 & 71.5 & 32.33 & 39.17 & 45.2 & & & 1.87 & & & 1.89 & {$[8]$} \\
\hline F-15 & 55.6 & 40.54 & 15.07 & 72.9 & & & 2.24 & & & 2.20 & {$[8]$} \\
\hline M-15 & 121.7 & 60.96 & 60.76 & 50.1 & & & 4.41 & & & 3.92 & {$[8]$} \\
\hline A-15 & 70.2 & 43.57 & 26.60 & 62.1 & & & 2.09 & & & 2.08 & {$[8]$} \\
\hline M-15 & 34.6 & 32.32 & 2.30 & 93.4 & & & 1.10 & & & 1.20 & {$[8]$} \\
\hline $\mathrm{J}-15$ & 50.9 & 24.92 & 25.94 & 49.0 & & & 0.48 & & & 0.59 & {$[8]$} \\
\hline $\mathrm{J}-15$ & 35.3 & 19.66 & 15.69 & 55.6 & & & 0.38 & & & 0.49 & {$[8]$} \\
\hline A- 15 & 37.9 & 13.89 & 24.06 & 36.6 & & & 0.57 & & & 0.69 & {$[8]$} \\
\hline S-15 & 35.3 & 14.35 & 20.95 & 40.7 & & & 1.15 & & & 1.25 & {$[8]$} \\
\hline O-15 & 35.9 & 17.91 & 17.95 & 49.9 & & & 0.57 & {$[4]$} & & 0.69 & {$[8]$} \\
\hline $\mathrm{N}-15$ & 32.2 & 16.57 & 15.60 & 51.5 & & & 0.47 & {$[4]$} & & 0.58 & {$[8]$} \\
\hline D-15 & 60.5 & 30.99 & 29.47 & 51.3 & 2015 & 1.41 & 1.56 & [4] & 1.43 & 1.61 & [8] \\
\hline
\end{tabular}

${ }^{1}$ See table 3.4 for Equations [1] and [4] relating base flow at gage with missing values (x) to base flow at Pennypack Creek at Pine Road. Equation [8] estimating monthly base flow at Iron Works gage (y) using monthly base flow at Pennypack Creek at Horsham (x):

$\mathrm{y}=1.1084 \mathrm{x}^{0.8509}$, where equation based on regression of instantaneous flow at Iron Works (IW) with Horsham daily values (dv) in CFS; for $\mathrm{v}=\mathrm{dv}$ Horsham, $\mathrm{w}=\mathrm{IW}$ instantaneous flow, $\mathrm{w}=1.1084 \mathrm{v}^{0.8509}, \mathrm{R}^{2}=0.5863$; see table 1.5 and figure 1.2. 


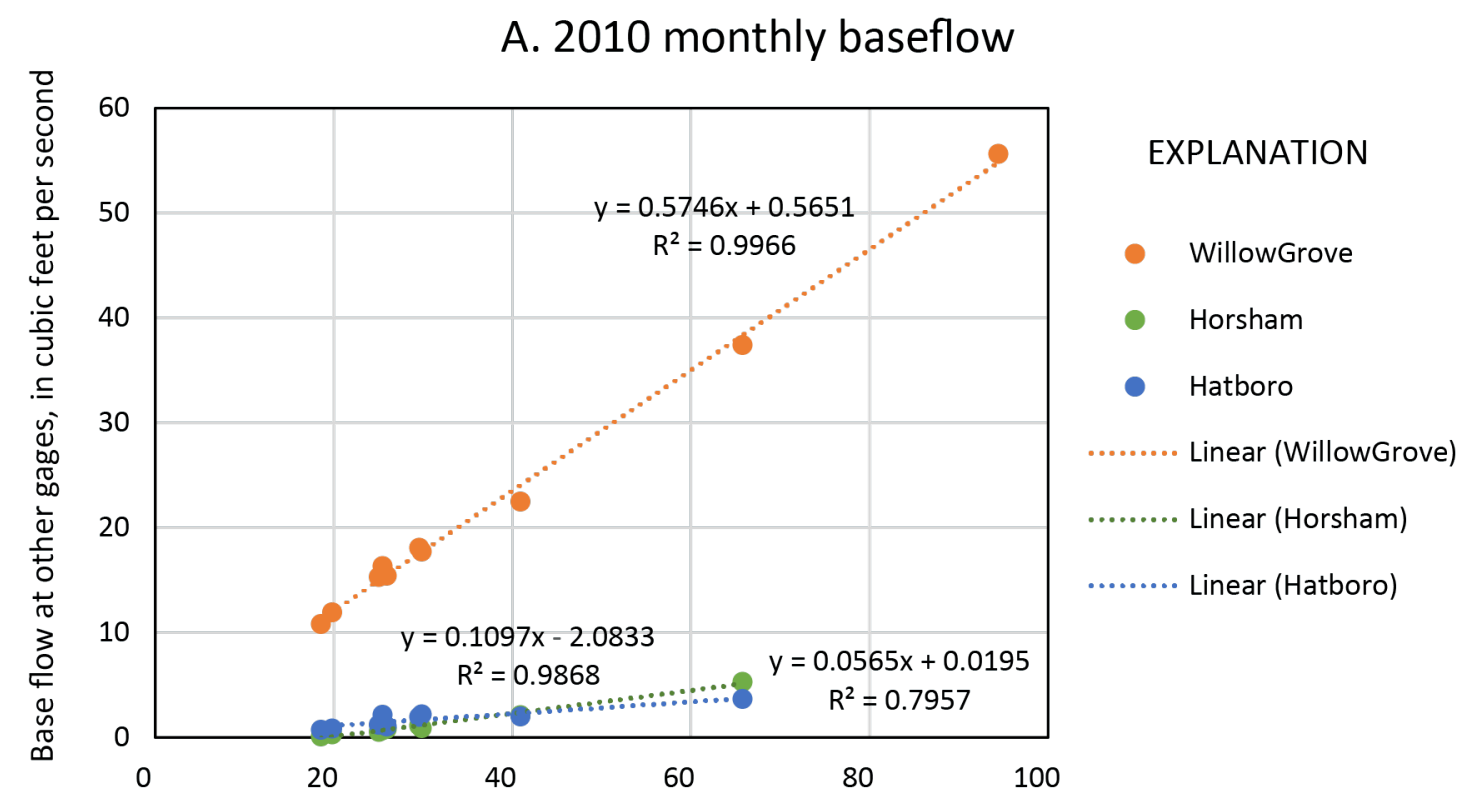

Base flow at Pennypack Creek at Pine Road, in cubic feet per second

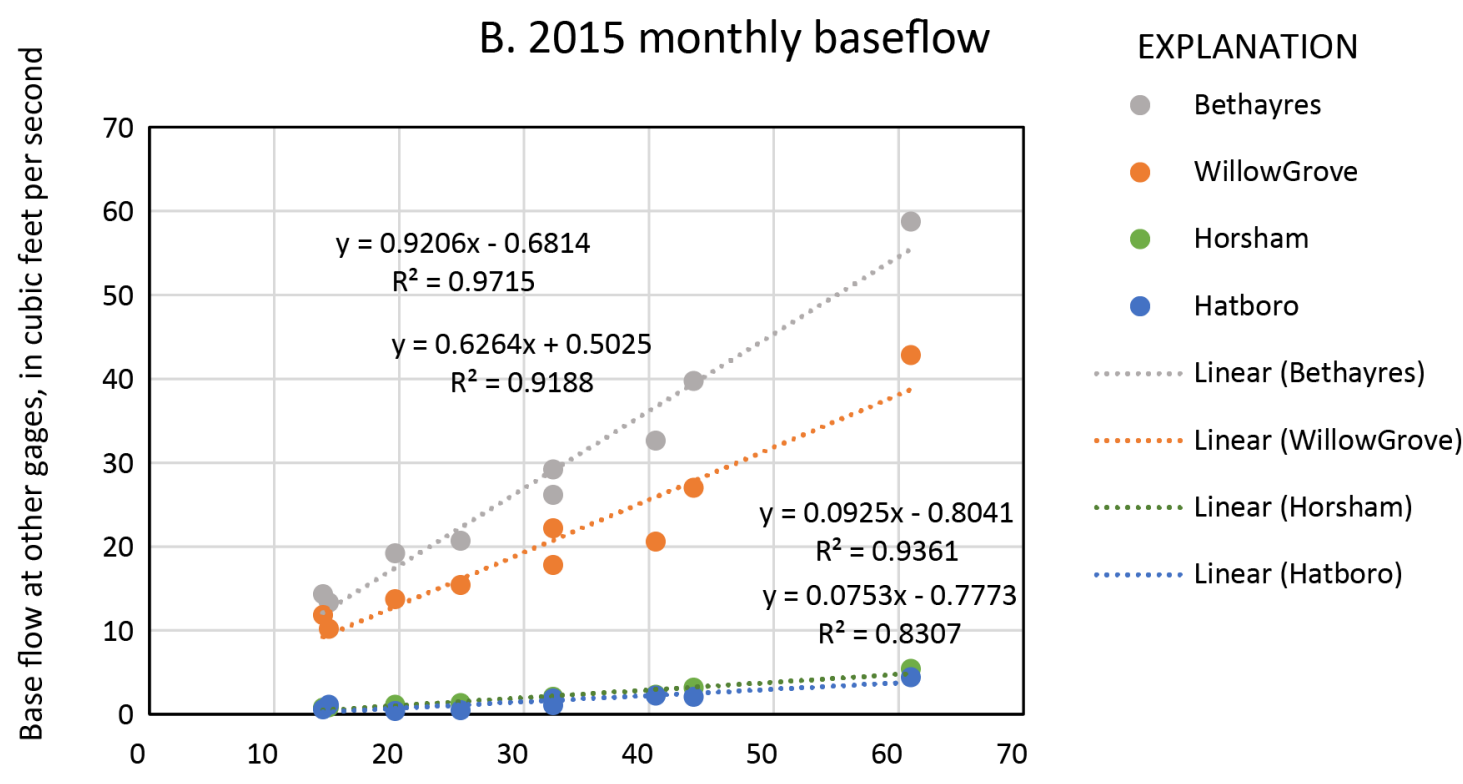

Base flow Pennypack Creek at PineRoad, in cubic feet per second

Figure 1.1. Regressions with (A) 2010 monthly base flow at U.S. Geological Survey gage Pennypack Creek at Pine Road and three other gages on Pennypack Creek: Horsham, Hatboro, Willow Grove; and (B) 2015 monthly base flow at U.S. Geological Survey gage Pennypack Creek at Pine Road and four other gages on Pennypack Creek: Horsham, Hatboro, Willow Grove, Bethayres. 


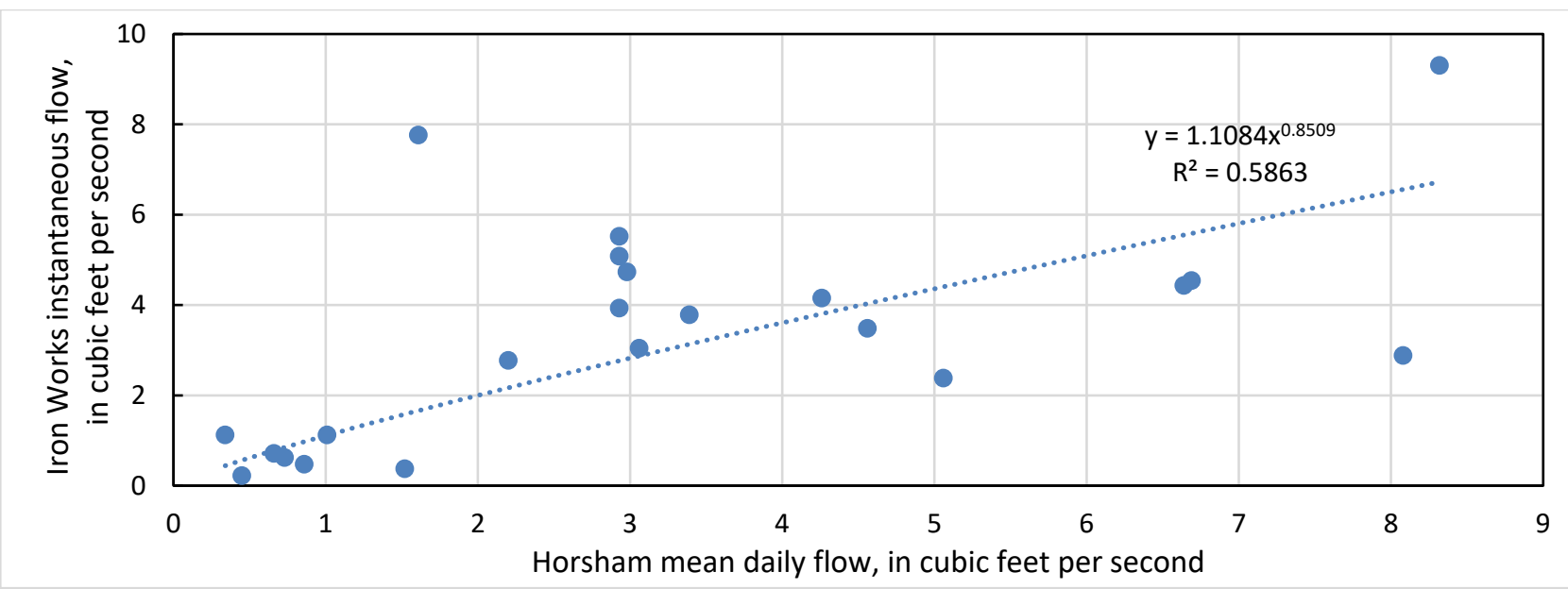

Figure 1.2. Regression between daily mean streamflow at gage 01467031 Pennypack Creek at Horsham and instantaneous streamflow at gage 01465460 Iron Works Creek at Richboro, 2010-15.

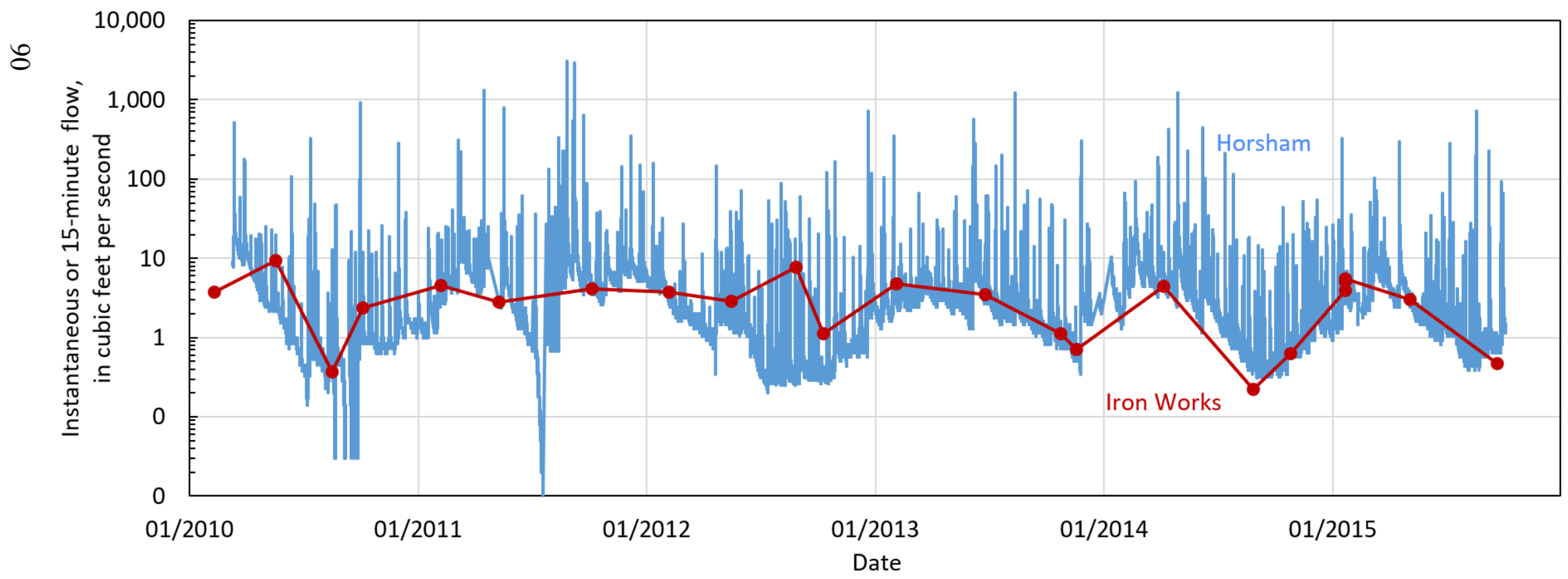

Figure 1.3. Instantaneous streamflow at gage 01465460 Iron Works Creek at Richboro and continuous 15-minute streamflow at gage 01467031 Pennypack Creek at Horsham, 2010-15. 


\section{Appendix 2. Model Calibration Results}

PEST ++ (Welter and others, 2015), which is based on the methods and algorithms of PEST (Doherty, 2015), was used for model calibration. Python scripts for PEST++ calibration of the model using FloPy (Bakker and others, 2016, 2018) and other Python libraries are provided in the model data release (Goode and Senior, 2020), along with all MODFLOW 6 input and output files. This appendix presents additional details on the model calibration results.

\section{Spatial Distribution of Water-Level Residuals}

The water-level residuals, or differences between observed and modeled values, are shown for the study area for 1999, 2010, 2013, and 2016 are shown in figures $2.1-2.4$. The modeled values are from the final calibration simulation.

\section{Parameter Sensitivities}

Composite scaled sensitivities (fig. 2.5) measure the extent to which each parameter is 'sensitive' to the measurements used for calibration (see White and others, 2019, p. 83). Parameters with high composite scaled sensitivity are relatively well constrained by the measurements, whereas parameters with low sensitivity are not. 


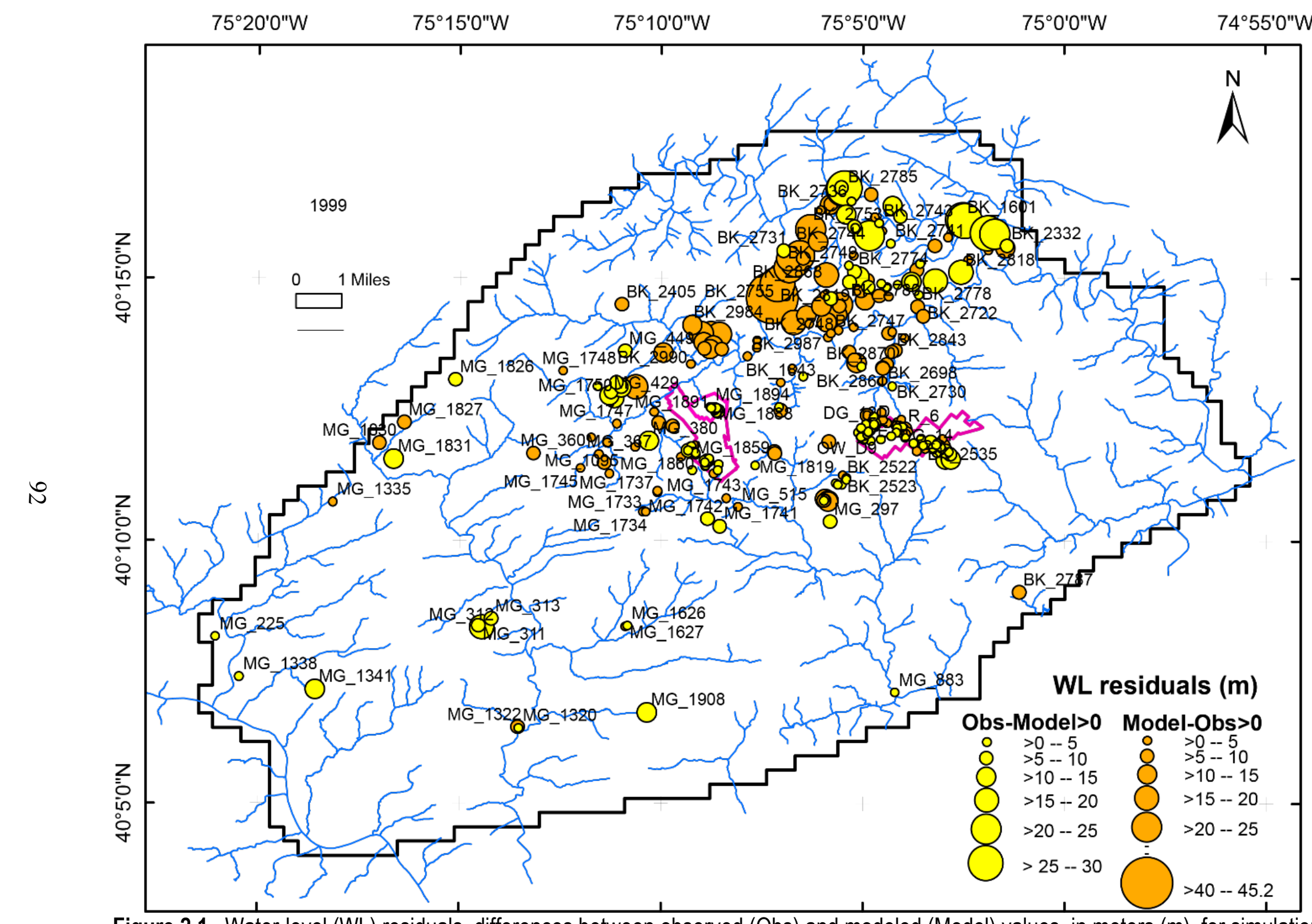

Figure 2.1. Water-level (WL) residuals, differences between observed (Obs) and modeled (Model) values, in meters (m), for simulation of 1999 conditions. 


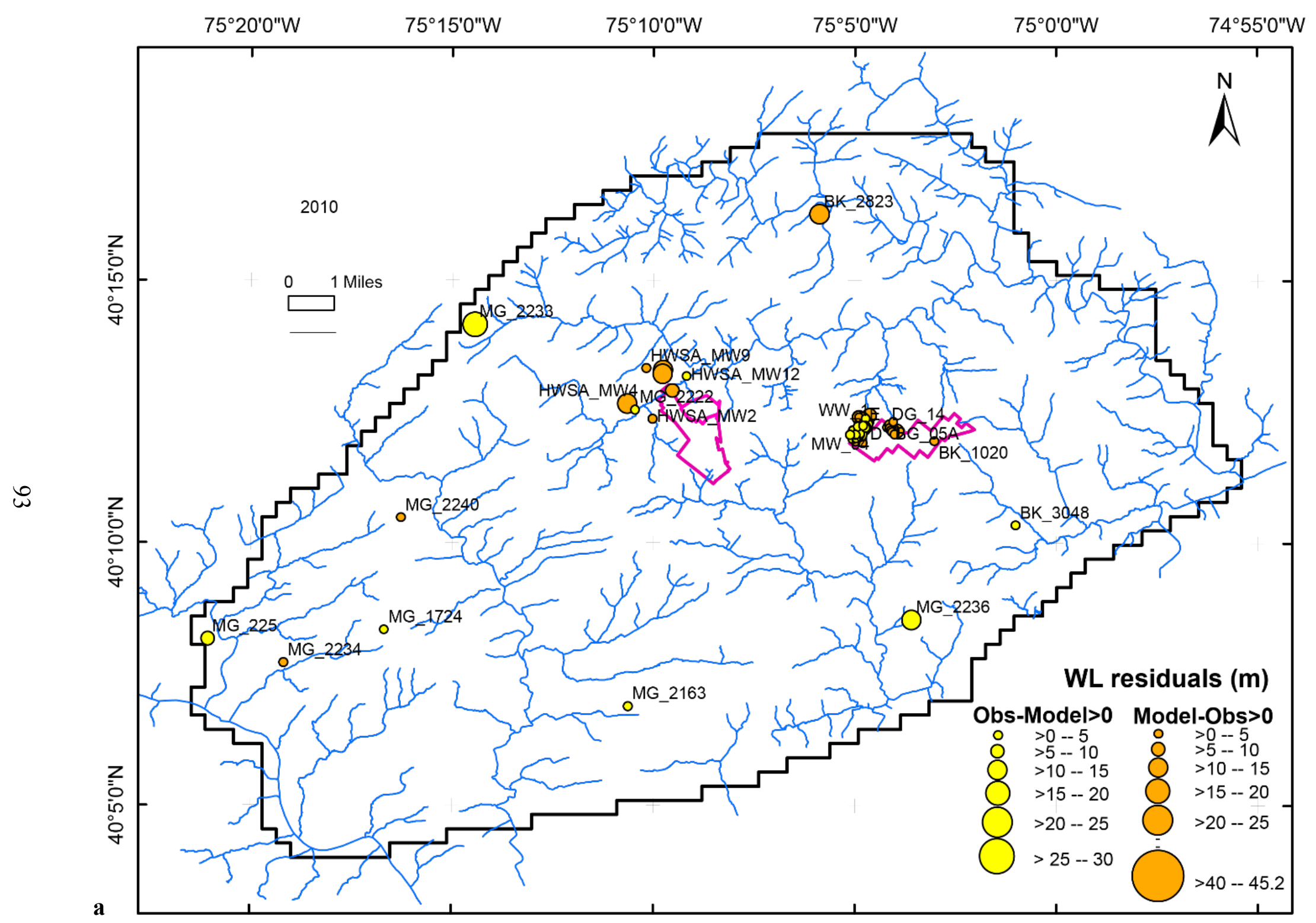

Figure 2.2. Water-level (WL) residuals, differences between observed (Obs) and modeled (Model) values, in meters ( $\mathrm{m}$ ), for simulation of 2010 conditions. 


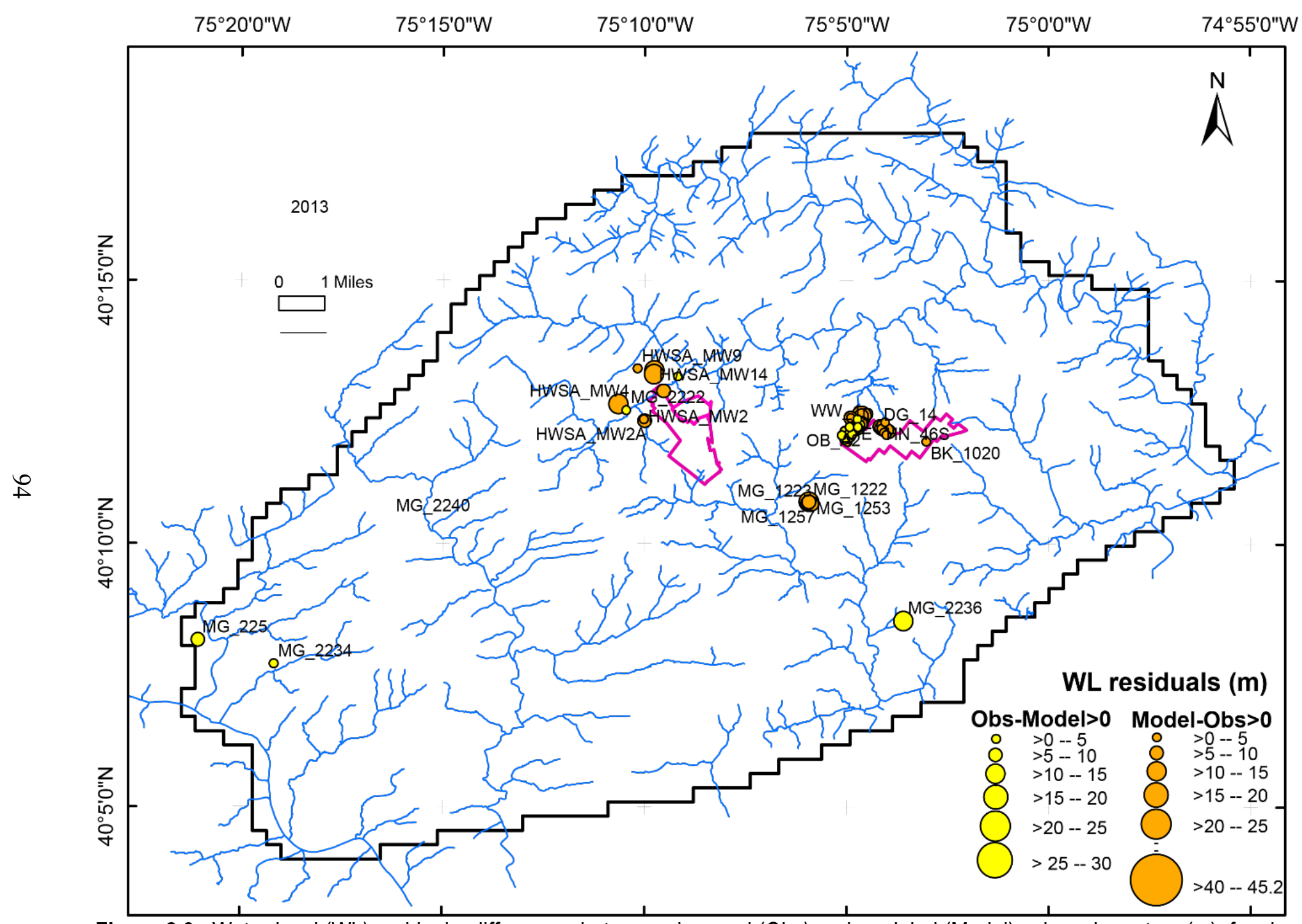

Figure 2.3. Water-level (WL) residuals, differences between observed (Obs) and modeled (Model) values, in meters (m), for simulation of 2013 conditions. 


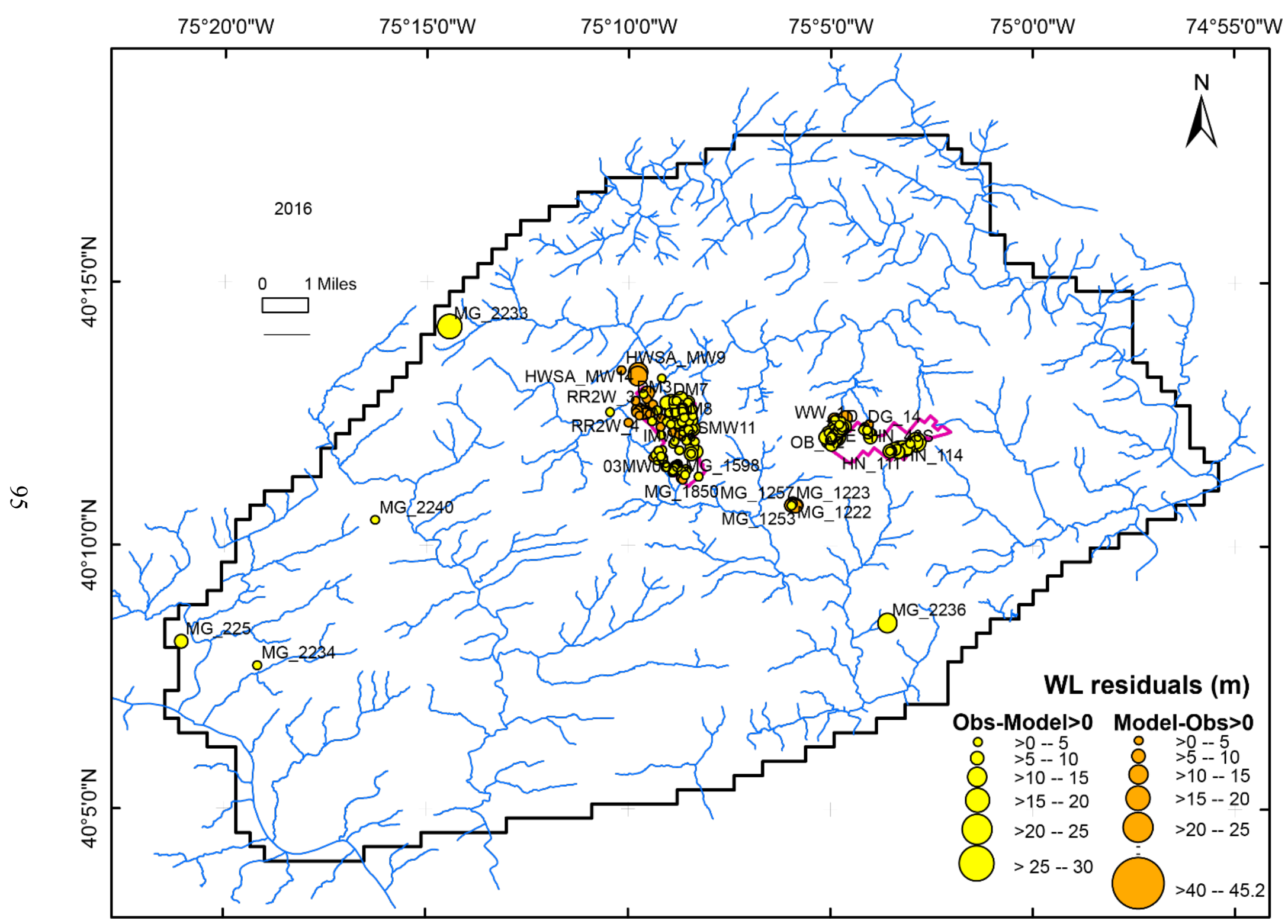

Figure 2.4. Water-level (WL) residuals, differences between observed (Obs) and modeled (Model) values, in meters $(\mathrm{m})$, for simulation of 2016 conditions. 


$$
\|
$$




\section{Recharge Rate Estimates}

All recharge values were scaled by a single model parameter. This parameter had the highest sensitivity to observations used for calibration (fig. 2.5). Recharge rates were highest in the Carbonate hydrogeologic zone and lowest in the Lockatong and Other zones (table 2.1, also see fig. 15).

Table 2.1. Optimum and approximate, individual, 95-percent confidence-interval values for recharge rates from calibration of the groundwater-flow model near Willow Grove and Warminster, Pennsylvania.

[2010 and 2013 rates; rates for 1999 are 0.9 times the values shown; rates for 2016 and 2017 are 0.7 times the values shown; m/day, meters per day; in/yr, inches per year]

\begin{tabular}{|c|c|c|c|c|c|c|}
\hline \multirow[t]{2}{*}{ Hydrogeologic zone } & Optimum & $\begin{array}{l}\text { Lower } \\
\text { bound }\end{array}$ & $\begin{array}{l}\text { Upper } \\
\text { bound }\end{array}$ & Optimum & $\begin{array}{l}\text { Lower } \\
\text { bound }\end{array}$ & $\begin{array}{l}\text { Upper } \\
\text { bound }\end{array}$ \\
\hline & \multicolumn{3}{|c|}{ m/day } & \multicolumn{3}{|c|}{ in/yr } \\
\hline Brunswick & 0.000587 & 0.000573 & 0.000601 & 8.43 & 8.23 & 8.63 \\
\hline Carbonate & 0.00117 & 0.001142 & 0.001198 & 16.81 & 16.41 & 17.21 \\
\hline Upper Stockton & 0.000685 & 0.000669 & 0.000701 & 9.85 & 9.61 & 10.08 \\
\hline Lockatong & 0.000587 & 0.000573 & 0.000601 & 8.43 & 8.23 & 8.63 \\
\hline Other & 0.000587 & 0.000573 & 0.000601 & 8.43 & 8.23 & 8.63 \\
\hline Middle and lower Stockton & 0.00088 & 0.000859 & 0.000901 & 12.65 & 12.35 & 12.95 \\
\hline
\end{tabular}




\section{Hydraulic Conductivity Estimates}

The final parameter values reflect regional-scale estimates of bulk hydraulic conductivity (fig. 2.6, table 2.2) based on water-level measurement, stream base flow, and the conceptual model. The Carbonate zone has the highest estimated K (42 ft/d). For the Newark Basin strata, the middle and lower members of the Stockton Formation, which underlies both Willow Grove and Warminster has the highest $\mathrm{Kx}(2.5 \mathrm{ft} / \mathrm{d})$, followed by the Lockatong Formation $(2.3 \mathrm{ft} / \mathrm{d})$ and lastly the upper member of the Stockton Formation $(1.2 \mathrm{ft} / \mathrm{d}) . \mathrm{Ky} / \mathrm{Kx}$ in the dip direction is essentially equal for the Lockatong Formation (0.1) and the upper member of the Stockton Formation (0.2). The Brunswick Group strata underlie only a small portion of the model domain and $\mathrm{K}$ was fixed based the low sensitivity to the calibration data.

The upper and lower confidence bounds reflect the relative uncertainty in the parameter values, which is smaller for the more sensitive parameters. The recharge parameter had the highest sensitivity, based on the weight used for the streamflow data, and has a narrow confidence interval (table 2.2). The streambed conductance has a relatively wide confidence interval.

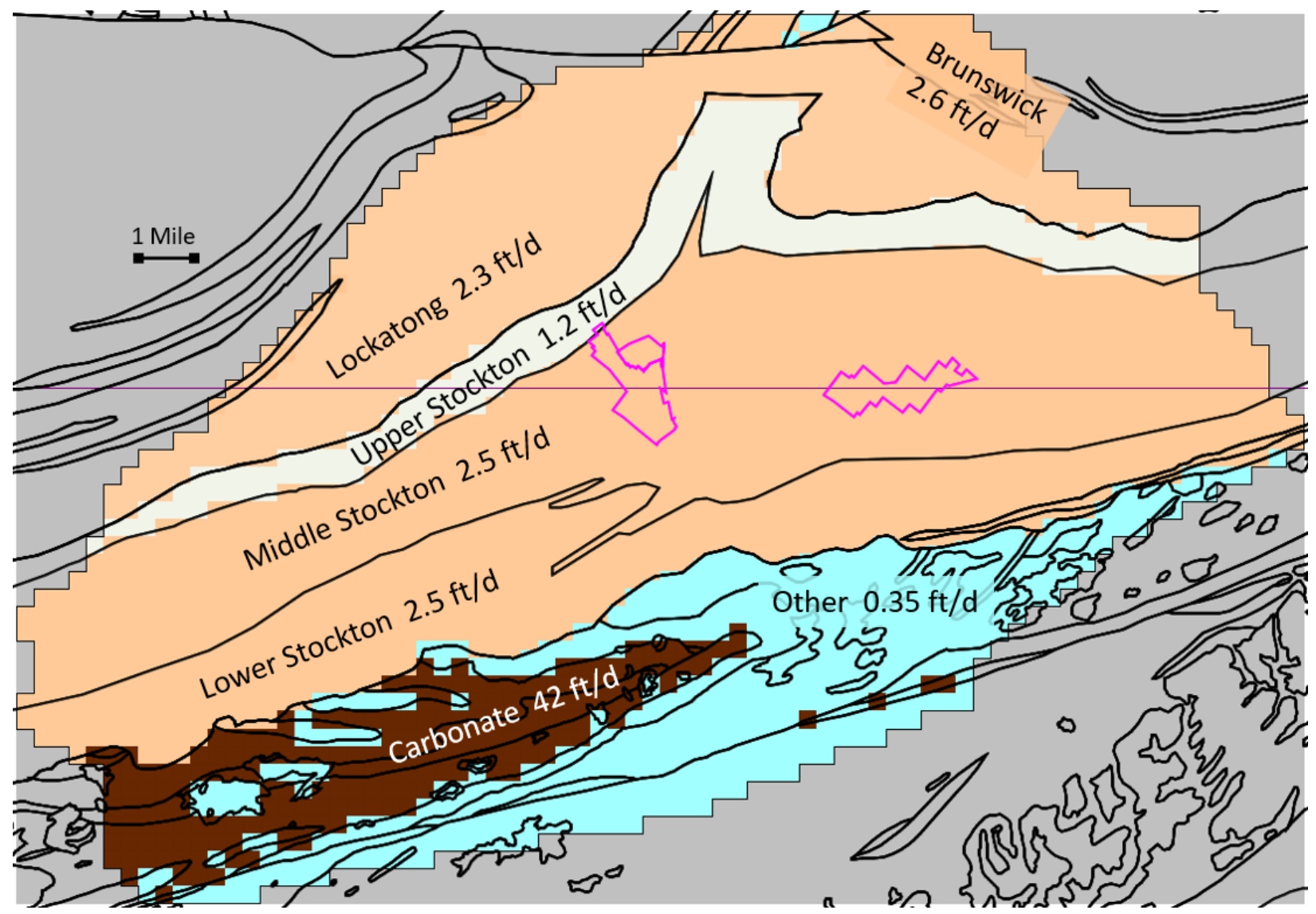

Figure 2.6. Estimated hydraulic conductivity in the strike direction (Kx) at depths between 125 and 400 feet below land surface in model area in layers 4 and 5 . Bases shown in magenta outline. 
Table 2.2. Optimum and approximate, individual 95-percent confidence-interval values for streambed and aquifer hydraulic conductivity estimated through calibration of the groundwater-flow model near Willow Grove and Warminster, Pennsylvania.

$[\mathrm{m} / \mathrm{d}$, meters per day; $\mathrm{ft} / \mathrm{d}$, feet per day; $\mathrm{K}$, hydraulic conductivity; $\mathrm{Kx}, \mathrm{K}$ in strike direction; $\mathrm{Ky}, \mathrm{K}$ in dip direction; $\mathrm{Kz}$, $\mathrm{K}$ perpendicular to bedding; --, not applicable or not available]

\begin{tabular}{|c|c|c|c|c|c|c|c|c|c|c|}
\hline \multirow{2}{*}{ Hydrogeologic zone } & \multirow{2}{*}{ Layers } & \multirow{2}{*}{ Method } & \multirow{2}{*}{$\begin{array}{l}\text { Metric } \\
\text { units }\end{array}$} & \multirow{2}{*}{$\begin{array}{l}\text { Optimum } \\
\text { value }\end{array}$} & \multicolumn{2}{|c|}{ Confidence bounds } & \multirow{2}{*}{$\begin{array}{l}\text { English } \\
\text { units }\end{array}$} & \multirow{2}{*}{$\begin{array}{l}\text { Optimum } \\
\text { value }\end{array}$} & \multicolumn{2}{|c|}{ Confidence bounds } \\
\hline & & & & & Lower & Upper & & & Lower & Upper \\
\hline & \multicolumn{10}{|c|}{ Streambed hydraulic conductivity } \\
\hline \multirow[t]{2}{*}{ All model streams } & 1 & Calibrate & $\mathrm{m} / \mathrm{d}$ & 1.61 & 0.23 & 10.7 & $\mathrm{ft} / \mathrm{d}$ & 5.28 & 0.75 & 35.1 \\
\hline & \multicolumn{10}{|c|}{ Hydraulic conductivity ( $\mathrm{Kx}$, max or strike value) } \\
\hline Weathered rock and overburden & 1,2 & Fixed & $\mathrm{m} / \mathrm{d}$ & 0.12 & -- & -- & $\mathrm{ft} / \mathrm{d}$ & 0.4 & -- & -- \\
\hline Brunswick Group & $3-7$ & Fixed & $\mathrm{m} / \mathrm{d}$ & 0.80 & -- & -- & $\mathrm{ft} / \mathrm{d}$ & 2.6 & -- & -- \\
\hline Lockatong Formation & $3-7$ & Calibrate & $\mathrm{m} / \mathrm{d}$ & 0.70 & 0.53 & 0.88 & $\mathrm{ft} / \mathrm{d}$ & 2.3 & 1.7 & 2.9 \\
\hline Stockton Formation, upper & $3-7$ & Tied $^{1}$ & $\mathrm{~m} / \mathrm{d}$ & 0.38 & 0.36 & 0.4 & $\mathrm{ft} / \mathrm{d}$ & 1.24 & 1.18 & 1.31 \\
\hline Stockton Formation, middle and lower & $3-7$ & Calibrate & $\mathrm{m} / \mathrm{d}$ & 0.758 & 0.719 & 0.80 & $\mathrm{ft} / \mathrm{d}$ & 2.5 & 2.4 & 2.6 \\
\hline Carbonate & $3-7$ & Calibrate & $\mathrm{m} / \mathrm{d}$ & 12.8 & 9.8 & 16.7 & $\mathrm{ft} / \mathrm{d}$ & 42 & 32 & 55 \\
\hline Other & $3-7$ & Fixed & $\mathrm{m} / \mathrm{d}$ & 0.106 & -- & -- & $\mathrm{ft} / \mathrm{d}$ & 0.35 & -- & -- \\
\hline
\end{tabular}

${ }^{1}$ Upper Stockton $\mathrm{Kx}=$ Middle and lower Stockton $\mathrm{Kx} / 2$.

\begin{tabular}{|c|c|c|c|c|c|c|c|c|}
\hline \multirow[b]{2}{*}{ Hydrogeologic zone } & \multicolumn{4}{|c|}{ Horizontal anisotropy } & \multicolumn{4}{|c|}{ Vertical anisotropy } \\
\hline & Layers & Method & $\begin{array}{l}\text { Optimum } \\
\text { value } \\
\text { (Ky/Kx) }\end{array}$ & $\begin{array}{l}\text { Optimum } \\
\text { value } \\
\text { (Kx/Ky) }\end{array}$ & Layers & Method & $\begin{array}{l}\text { Optimum } \\
\text { value } \\
\text { (Ky/Kx) }\end{array}$ & $\begin{array}{c}\text { Optimum } \\
\text { value } \\
\text { (Kx/Ky) }\end{array}$ \\
\hline Weathered rock and overburden & 1,2 & Fixed & 1 & 1 & 1,2 & Fixed & 0.33 & 3 \\
\hline Brunswick Group & $3-7$ & Fixed & 0.33 & 3 & $3-7$ & Fixed & 0.1 & 10 \\
\hline Lockatong Formation & $3-7$ & $\operatorname{Tied}^{2}$ & 0.1 & 10 & $3-7$ & Tied $^{2}$ & 0.1 & 10 \\
\hline Stockton Formation, upper & $3-7$ & $\operatorname{Tied}^{3}$ & 0.18 & 5.4 & $3-7$ & Tied $^{2}$ & 0.1 & 10 \\
\hline Stockton Formation, middle and lower & $3-7$ & Calibrate & 0.18 & 5.4 & $3-7$ & Tied $^{2}$ & 0.1 & 10 \\
\hline Carbonate & $3-7$ & $\operatorname{Tied}^{2}$ & 1 & 1 & $3-7$ & Tied $^{2}$ & 0.33 & 3 \\
\hline Other & $3-7$ & Fixed & 1 & 1 & $3-7$ & Fixed & 0.33 & 3 \\
\hline
\end{tabular}

${ }^{2}$ Tied to Kx for the respective hydrogeologic zone.

${ }^{3}$ Upper Stockton $\mathrm{Ky} / \mathrm{Kx}=$ Middle and lower Stockton $\mathrm{Ky} / \mathrm{Kx}$. 


\section{References}

Bakker, M., Post, V., Langevin, C.D., Hughes, J.D., White, J.T., Starn, J.J. and Fienen, M.N., 2016, Scripting MODFLOW model development using Python and FloPy: Groundwater, v. 54, p. 733-739, accessed July 9, 2017, at https://doi.org/10.1111/gwat.12413.

Bakker, M., Post, V., Langevin, C.D., Hughes, J.D., White, J.T., Starn, J.J., and Fienen, M.N., 2018, FloPy_-Python package for creating, running, and post-processing MODFLOW-based models (ver. 3.2.10): U.S. Geological Survey software release, accessed October 19, 2018, at https://doi.org/10.5066/F7BK19FH.

Doherty, J., 2015, Calibration and uncertainty analysis for complex environmental models:

Brisbane, Australia, Watermark Numerical Computing, $227 \mathrm{p}$.

Goode, D.J., and Senior, L.A., 2020, MODFLOW 6 and MODPATH 7 model data sets used to evaluate groundwater flow in the vicinity of Horsham and Warminster, Bucks and Montgomery Counties, Pennsylvania-Preliminary simulations for conditions in 1999, 2010, 2013, 2016, and 2017: U.S. Geological Survey data release, https://doi.org/10.5066/P9K36P5S.

Welter, D.E., White, J.T., Hunt, R.J., and Doherty, J.E., 2015, Approaches in highly parameterized inversion-PEST++ Version 3, a Parameter ESTimation and uncertainty analysis software suite optimized for large environmental models: U.S. Geological Survey Techniques and Methods, book 7, section C12, 54 p. 


\section{Appendix 3. Simulated Water Levels and Groundwater-Flow Paths}

MODPATH 7 (Pollock, 2016, 2017) was used to calculate groundwater-flow paths to discharge areas under assumed steady-state flow for conditions in 1999, 2010, 2013, 2016, and 2017. The overall water budget of the model aquifer consists of a balance between the recharge inflow, and some stream loss, and total outflows, which include base-flow discharge to streams and well withdrawals. The ultimate disposition of recharge in each model cell can be visualized from MODPATH particle tracking to show areas of recharge that discharges either to wells or to streams. All model input and output files, including MODFLOW 6 files, are provided in the model archive data release (Goode and Senior, 2020).

Per- and polyfluoroalkyl substances (PFAS) contamination has been identified at and near the Willow Grove and Warminster bases. To help understand groundwater migration of contaminants, regional flow paths are produced from identified possible locations of PFAS contamination in groundwater to their ultimate discharges, to either streams or wells for the five time periods.

Maps of simulated water levels, areas contributing recharge to wells and to streams, and regional groundwater-flow paths from possible sources are shown for the four calibration periods (1999, 2010, 2013, and 2016) and for the simulation of conditions in 2017. 


\section{Conditions}

Simulated water levels for the calibrated model in layer 1 for 1999 conditions are shown in figure 3.1. The 1999 conditions included the largest well withdrawals, so a higher proportion of recharge was captured by wells in this simulation (fig. 3.2), compared to the other time periods. These conditions used data from other dates in the 1990s. For example, withdrawal rates were from 1996 records (Delaware River Basin Commission, 2019). Regional groundwater-flow paths for 1999 conditions are shown in figures 3.3-3.5.

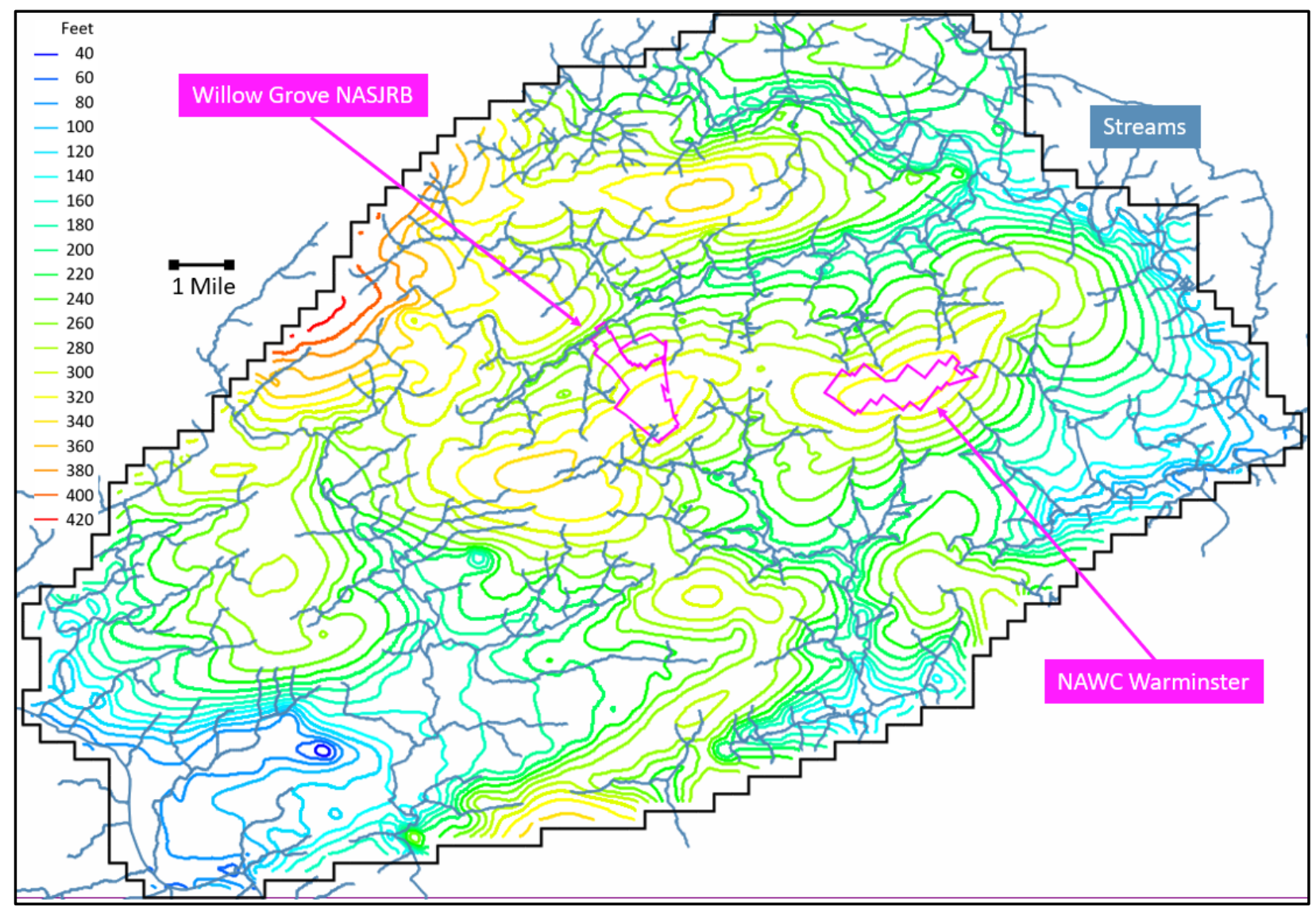

Figure 3.1. ModelMuse screenshot of simulated potentiometric surface in model layer 1 for 1999 conditions. The contour interval is 20 feet. 


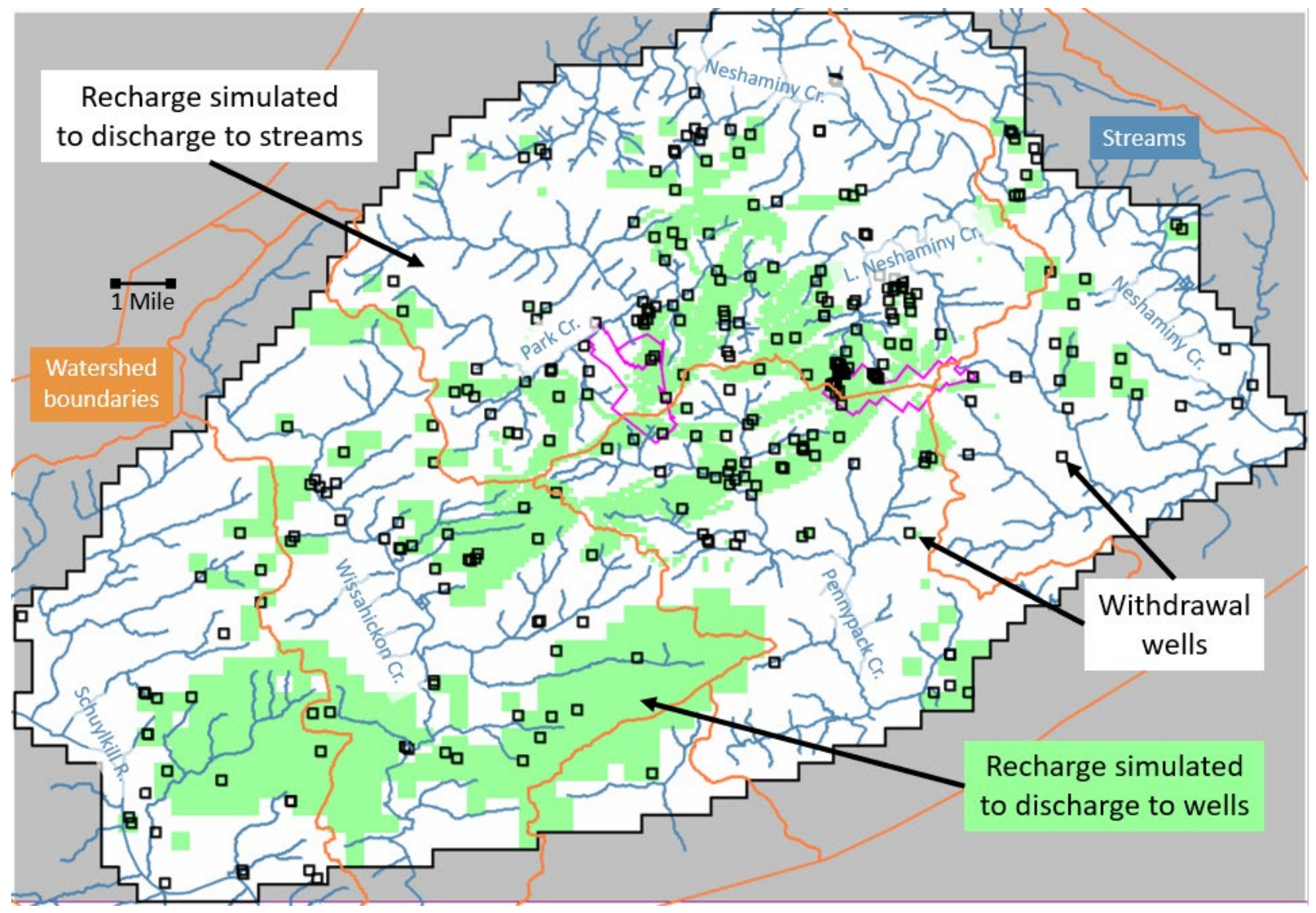

Figure 3.2. ModelMuse screenshot of simulated areas that contribute recharge to discharging wells (green) and streams (white) for 1999 conditions. 


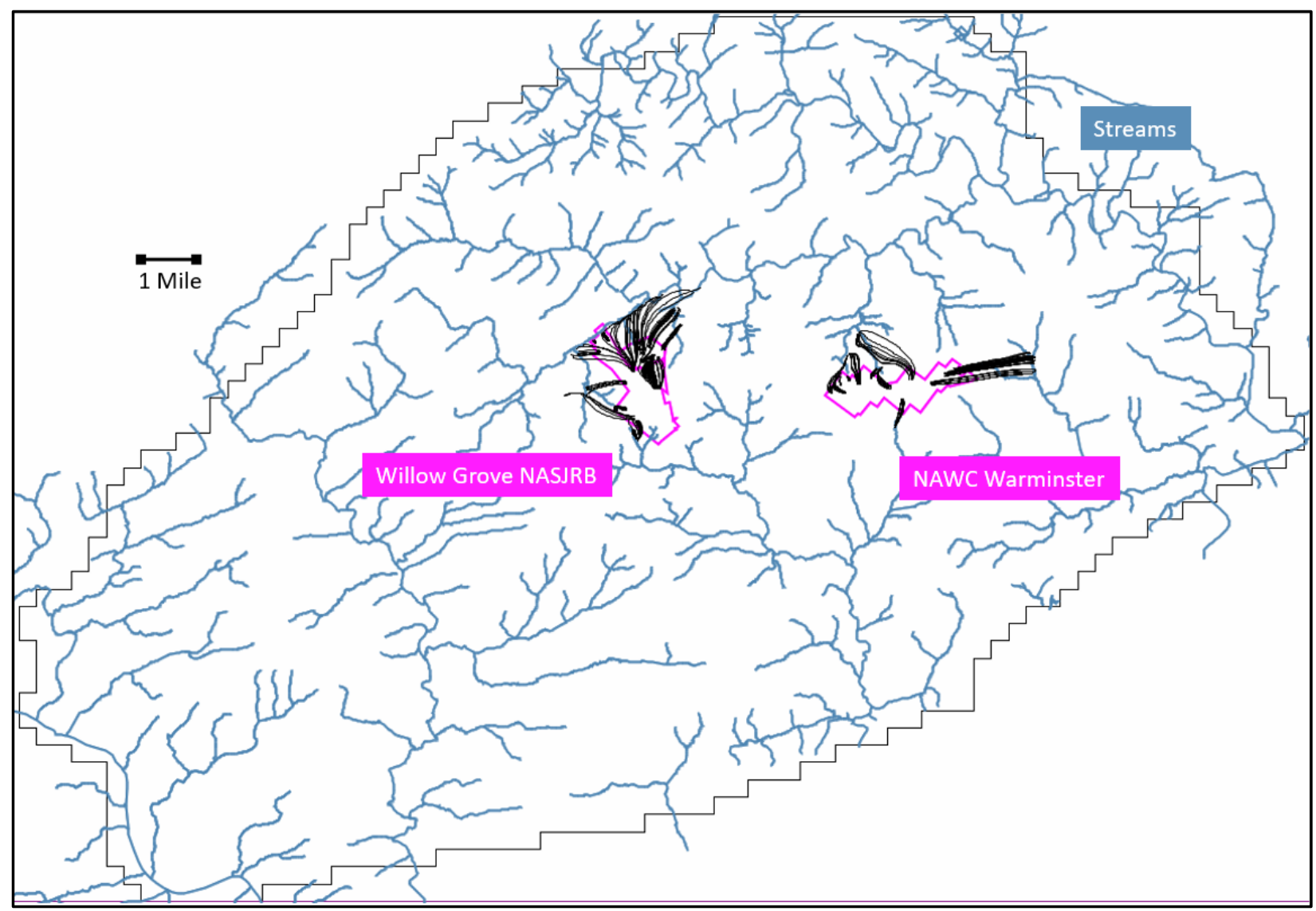

Figure 3.3. ModelMuse screenshot of simulated regional groundwater-flow paths (black) from locations of possible per- and polyfluoroalkyl substances (PFAS) contamination in groundwater for 1999 conditions. 


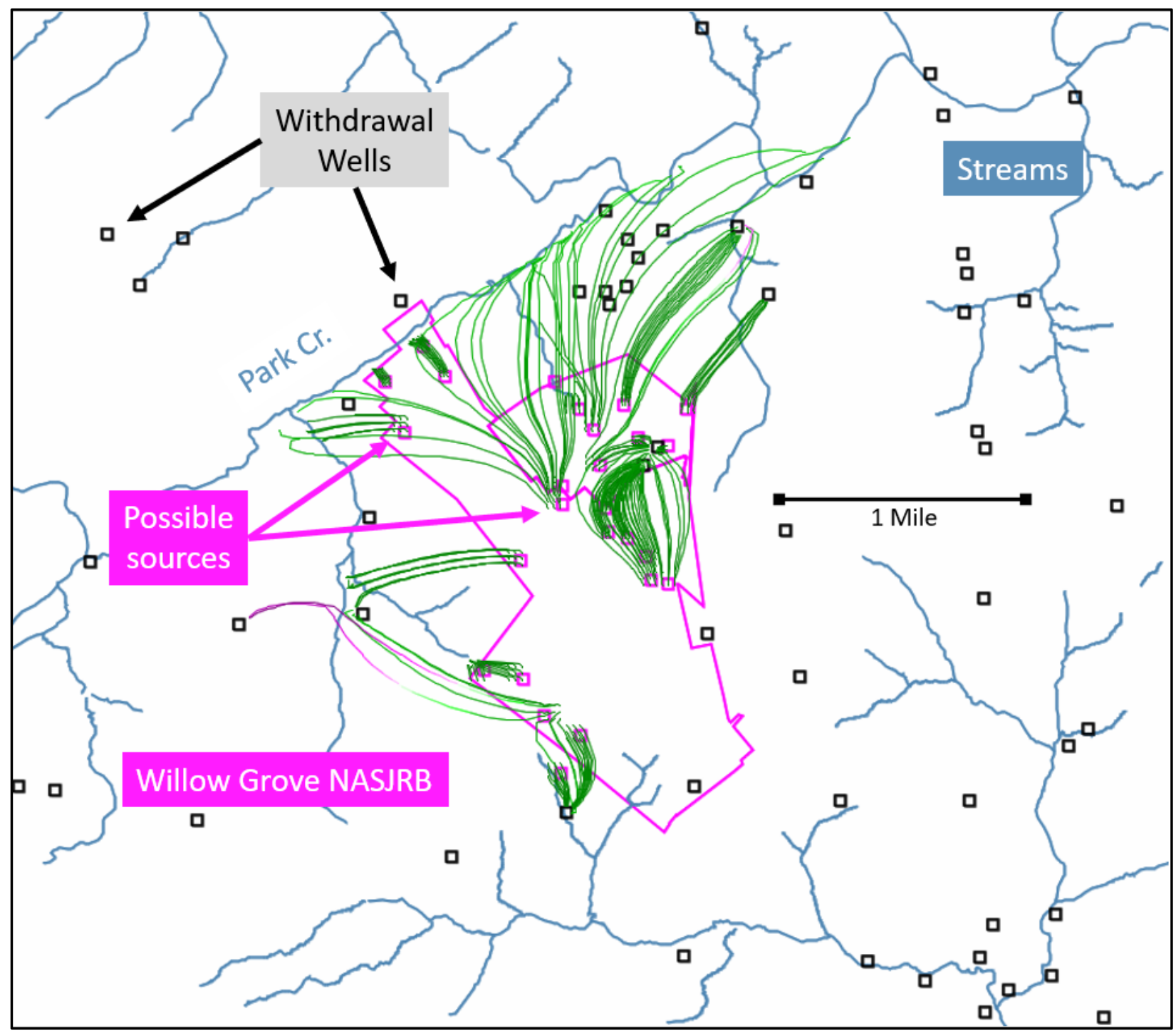

Figure 3.4. Detail of ModelMuse screenshot of simulated regional groundwater-flow paths for 1999 conditions near Willow Grove, with withdrawal wells in black. Pink squares represent locations of possible per- and polyfluoroalkyl substances (PFAS) contamination in groundwater. Colors along paths range from green for relatively short travel times to magenta for relatively long travel times. 


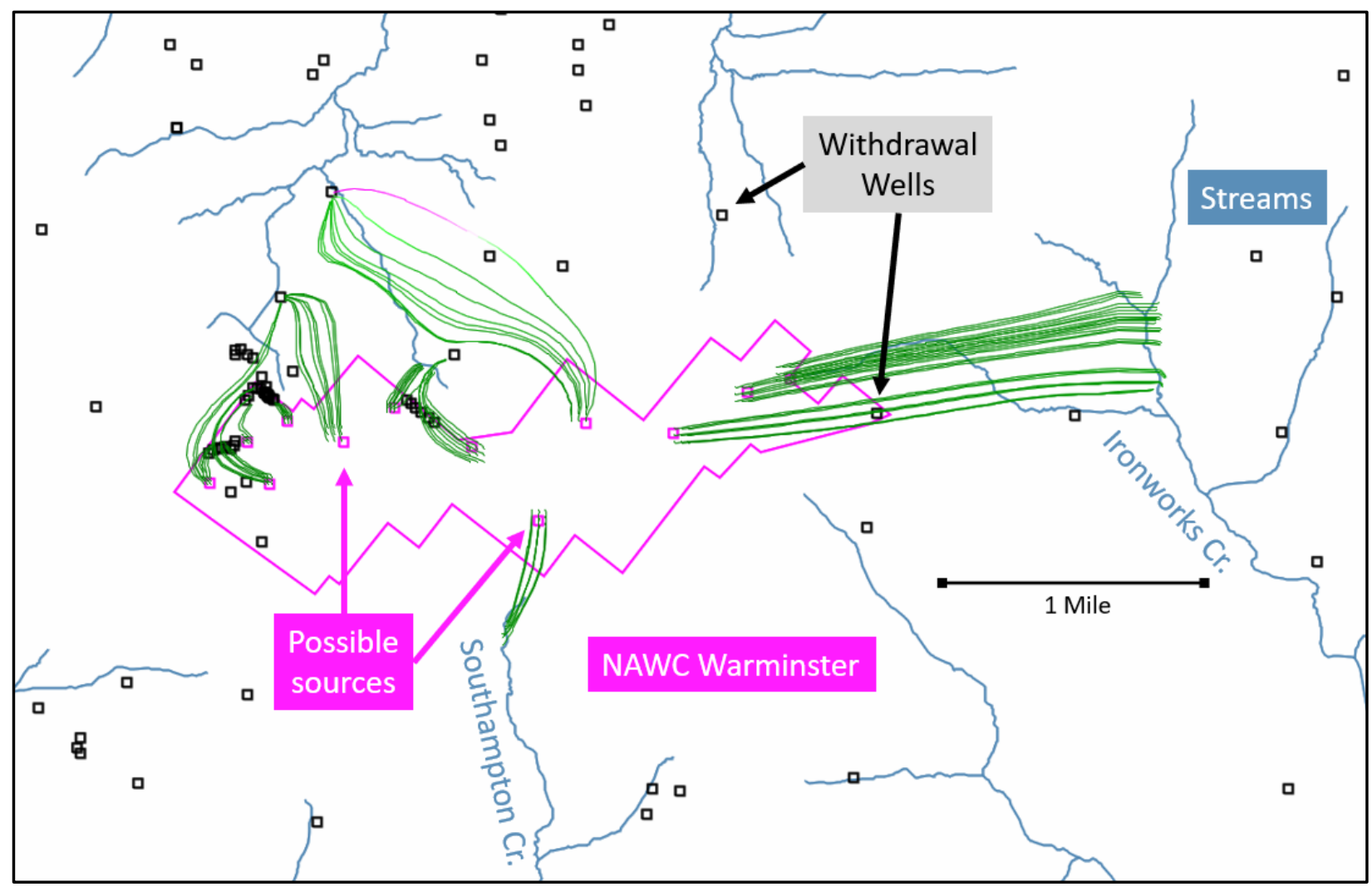

Figure 3.5. Detail of ModelMuse screenshot of simulated regional groundwater-flow paths for 1999 conditions near Warminster, with withdrawal wells in black. Pink squares represent locations of possible per- and polyfluoroalkyl substances (PFAS) contamination in groundwater. Colors along paths range from green for relatively short travel times to magenta for relatively long travel times. 


\section{Conditions}

Simulated water levels for the calibrated model in layer 1 for 2010 conditions are shown in figure 3.6 and recharge simulated to be discharged to wells and streams is shown in figure 3.7. Willow Grove base production wells were in operation for this simulation. Recharge from precipitation was the highest in this period and in 2013. Regional groundwater-flow paths for 2010 conditions are shown in figures 3.8-3.10.

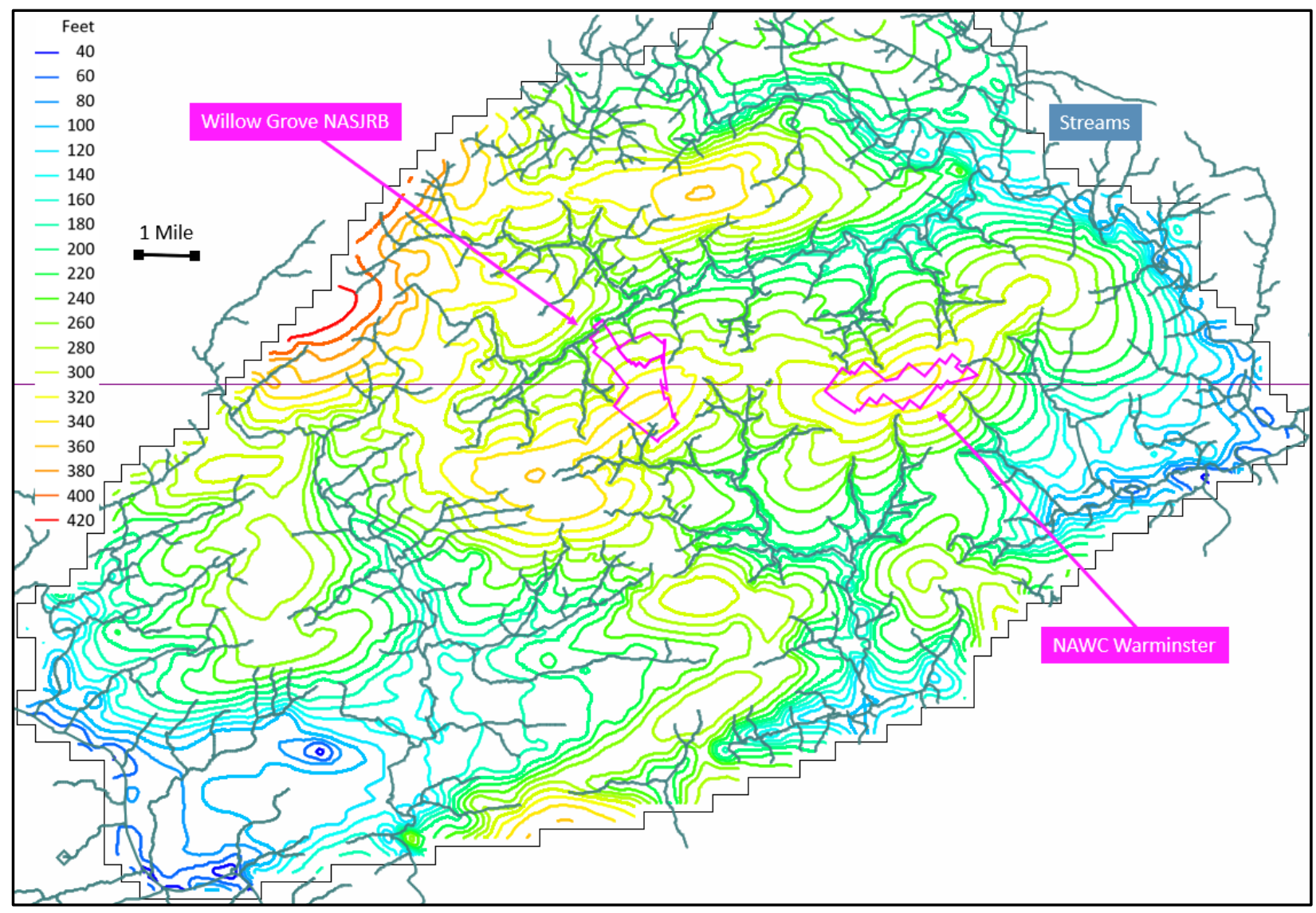

Figure 3.6. ModelMuse screenshot of simulated potentiometric surface in model layer 1 for 2010 conditions. The contour interval is 20 feet. 


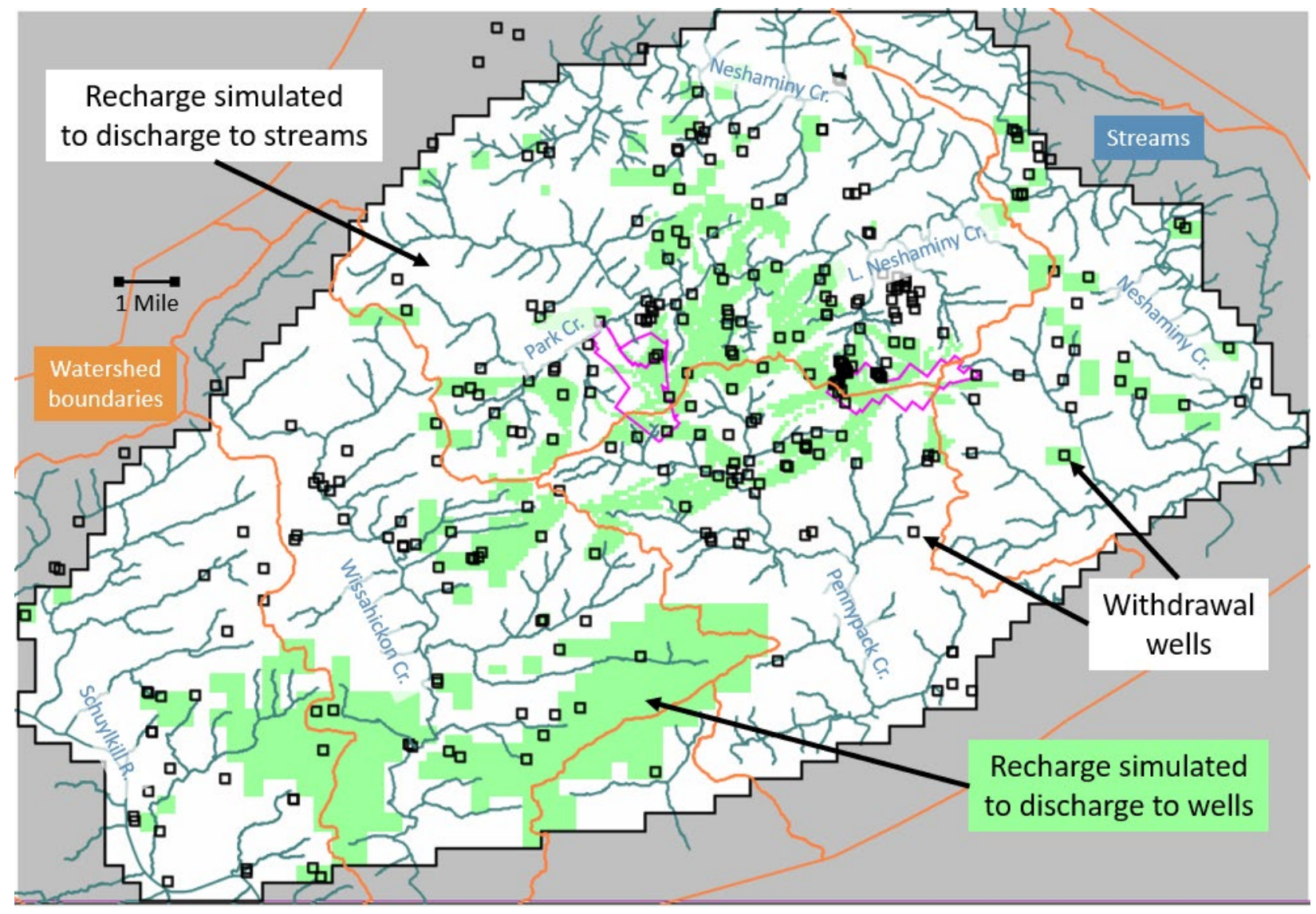

Figure 3.7. ModelMuse screenshot of simulated areas that contribute recharge to discharging wells (green) and streams (white) for 2010 conditions. 


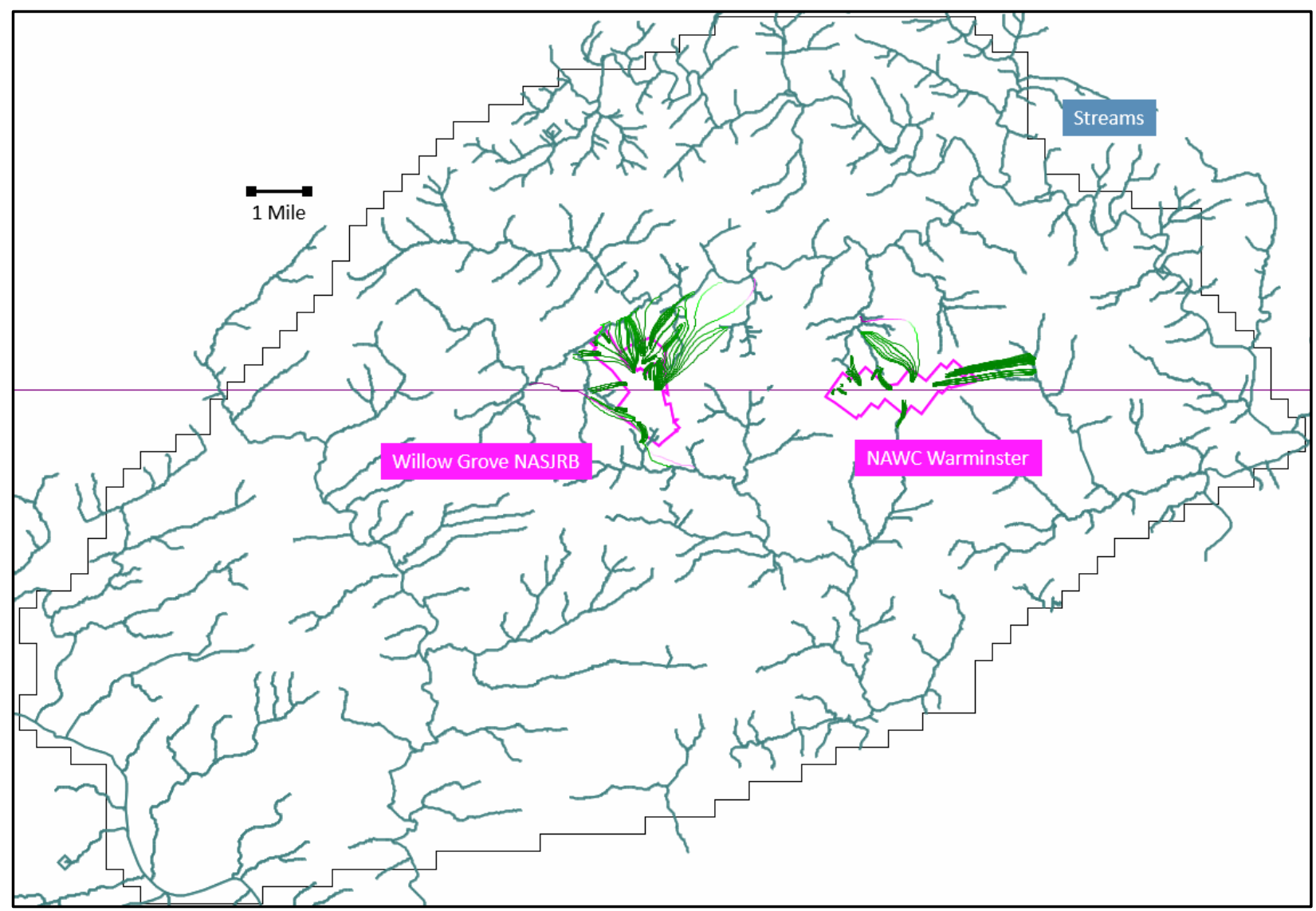

Figure 3.8. ModelMuse screenshot of simulated regional groundwater-flow paths from possible per- and polyfluoroalkyl substances (PFAS) contamination sources for 2010 conditions. Colors along paths range from green for relatively short travel times to magenta for relatively long travel times. 


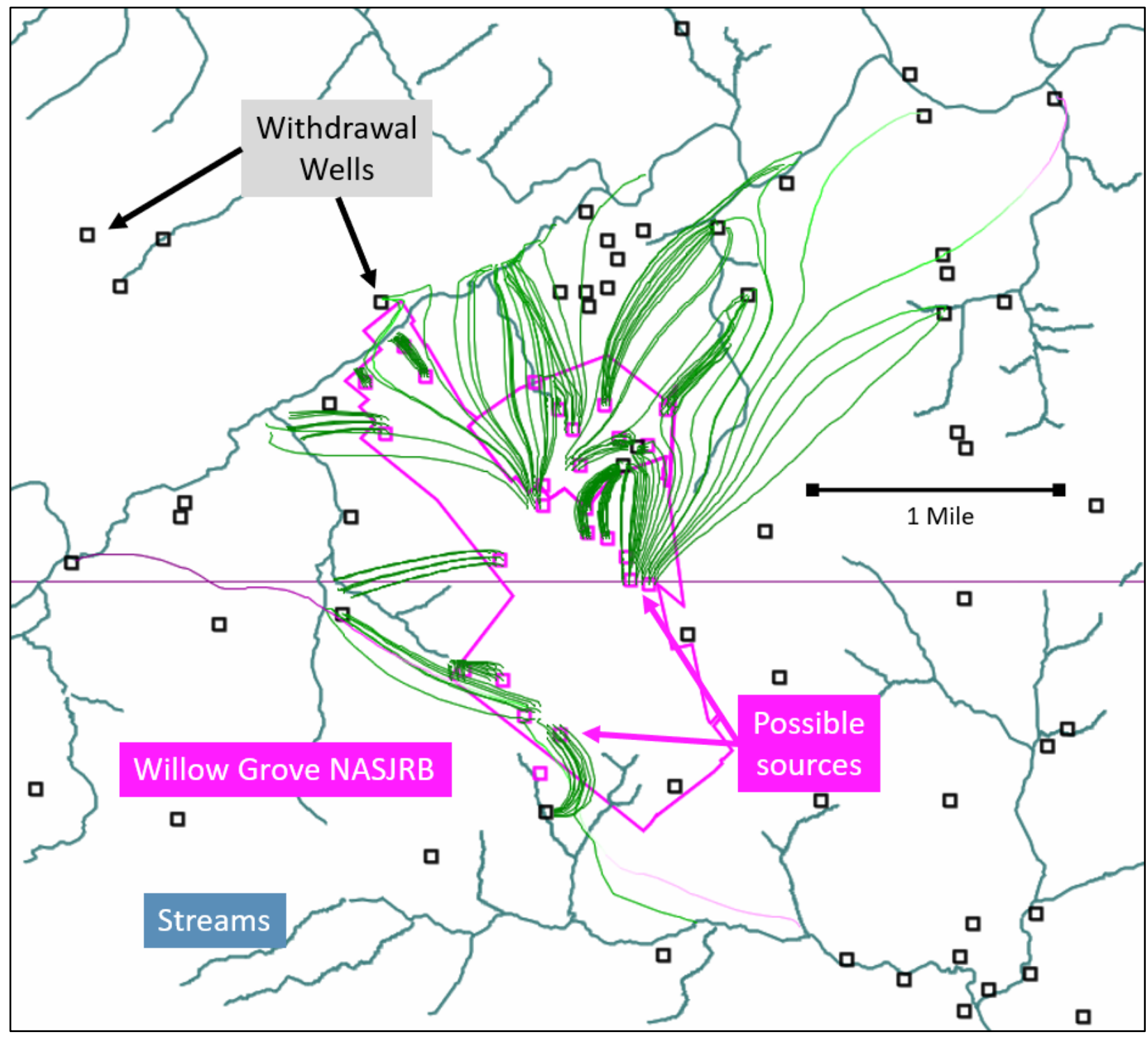

Figure 3.9. Detail of ModelMuse screenshot of simulated regional groundwater-flow paths for 2010 conditions near Willow Grove with withdrawal wells in black. Pink squares represent areas of possible perand polyfluoroalkyl substances (PFAS) contamination in groundwater. Colors along paths range from green for relatively short travel times to magenta for relatively long travel times. 


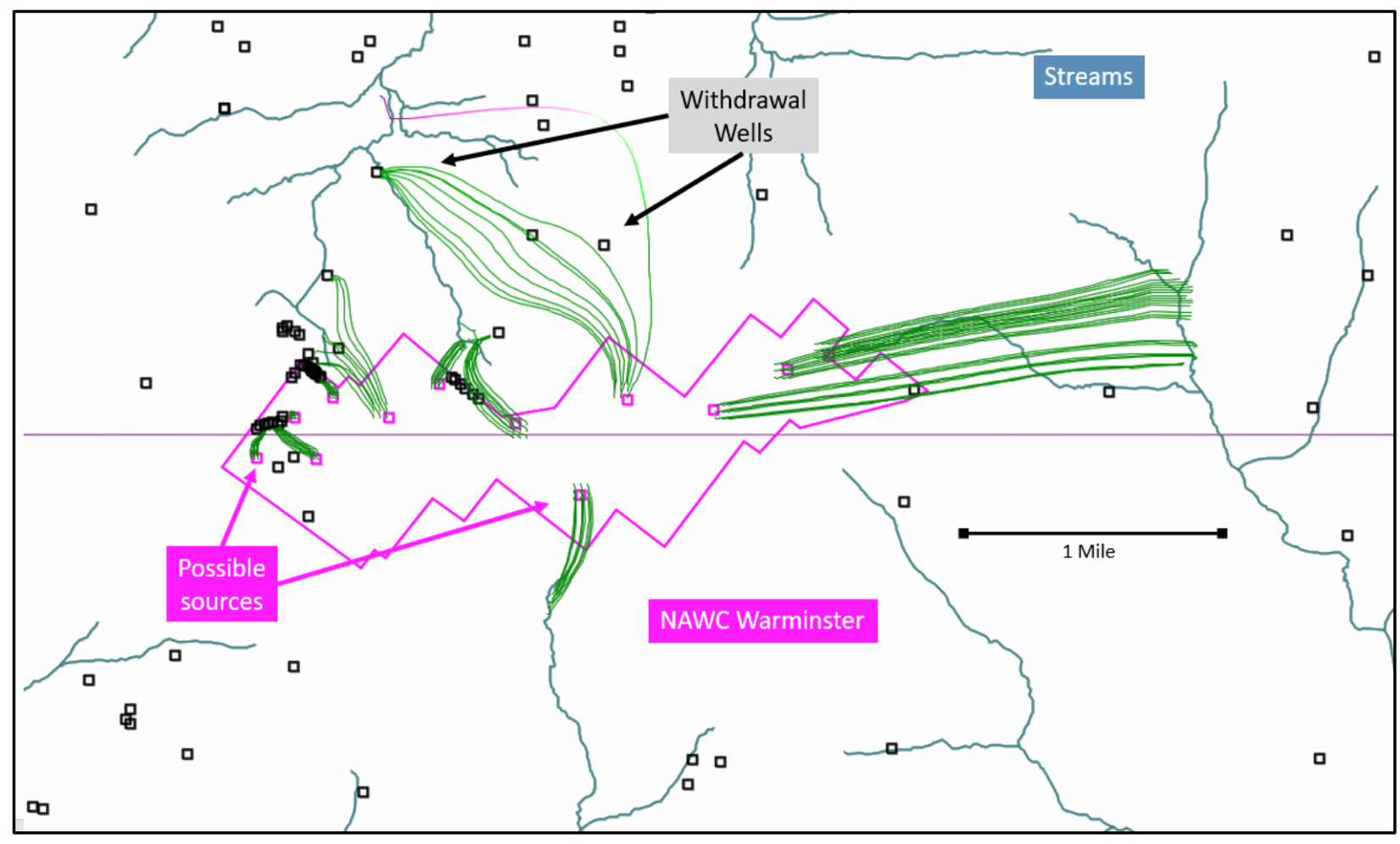

Figure 3.10. Detail of ModelMuse screenshot of simulated regional groundwater-flow paths for 2010 conditions near Warminster, with withdrawal wells in black. Pink squares represent areas of possible perand polyfluoroalkyl substances (PFAS) contamination in groundwater. Colors along paths range from green for relatively short travel times to magenta for relatively long travel times. 


\section{Conditions}

Simulated water levels for the calibrated model in layer 1 for 2013 conditions are shown in figure 3.11 and recharge simulated to be discharged to wells and streams is shown in figure 3.12. Willow Grove base production wells and many public supply wells in the area were not in operation. Recharge from precipitation was the highest in this period and in 2010. Regional groundwater-flow paths for 2013 conditions are shown in figures 3.13-3.15.

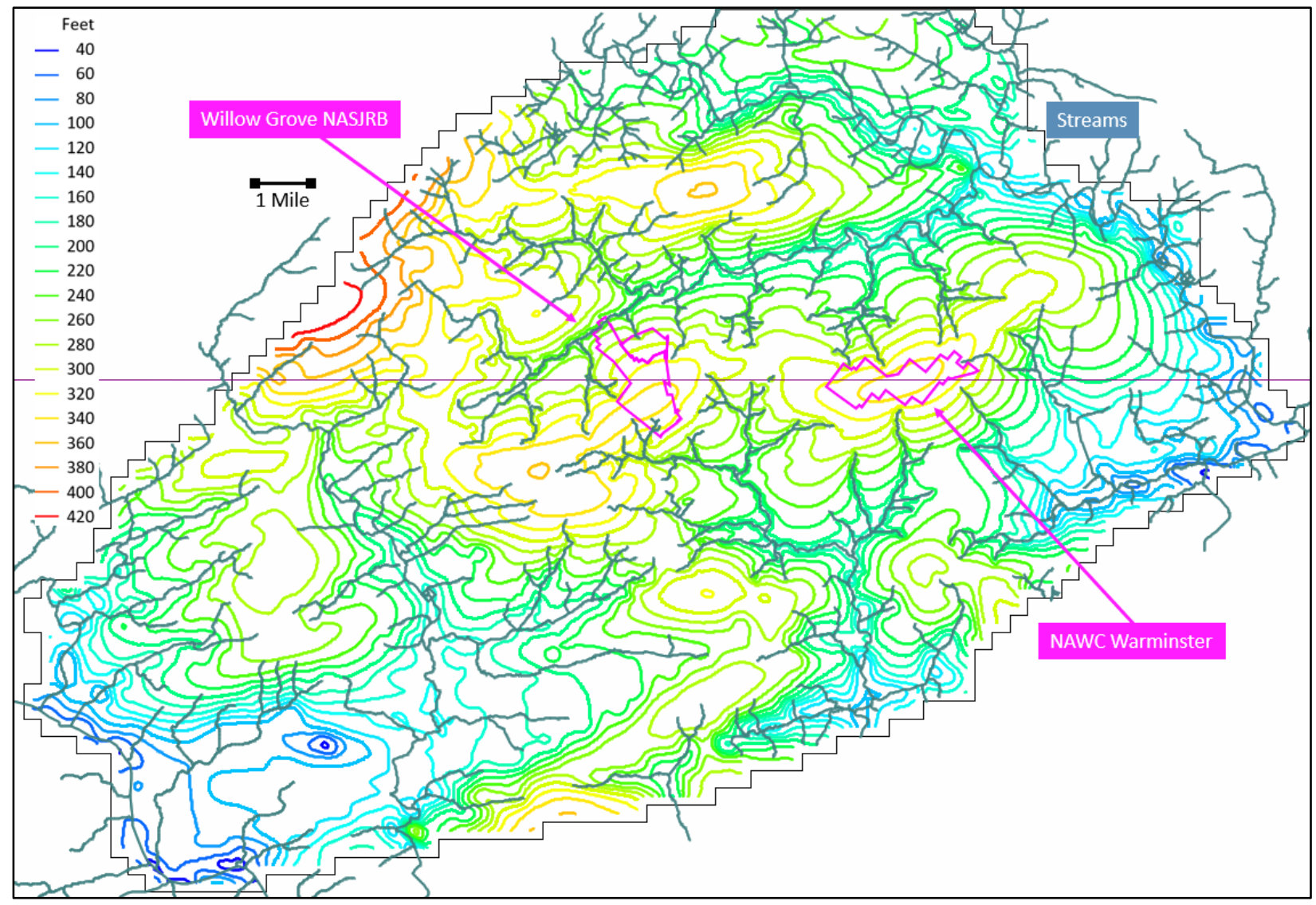

Figure 3.11. ModelMuse screenshot of simulated potentiometric surface in model layer 1 for 2013 conditions. The contour interval is 20 feet. 


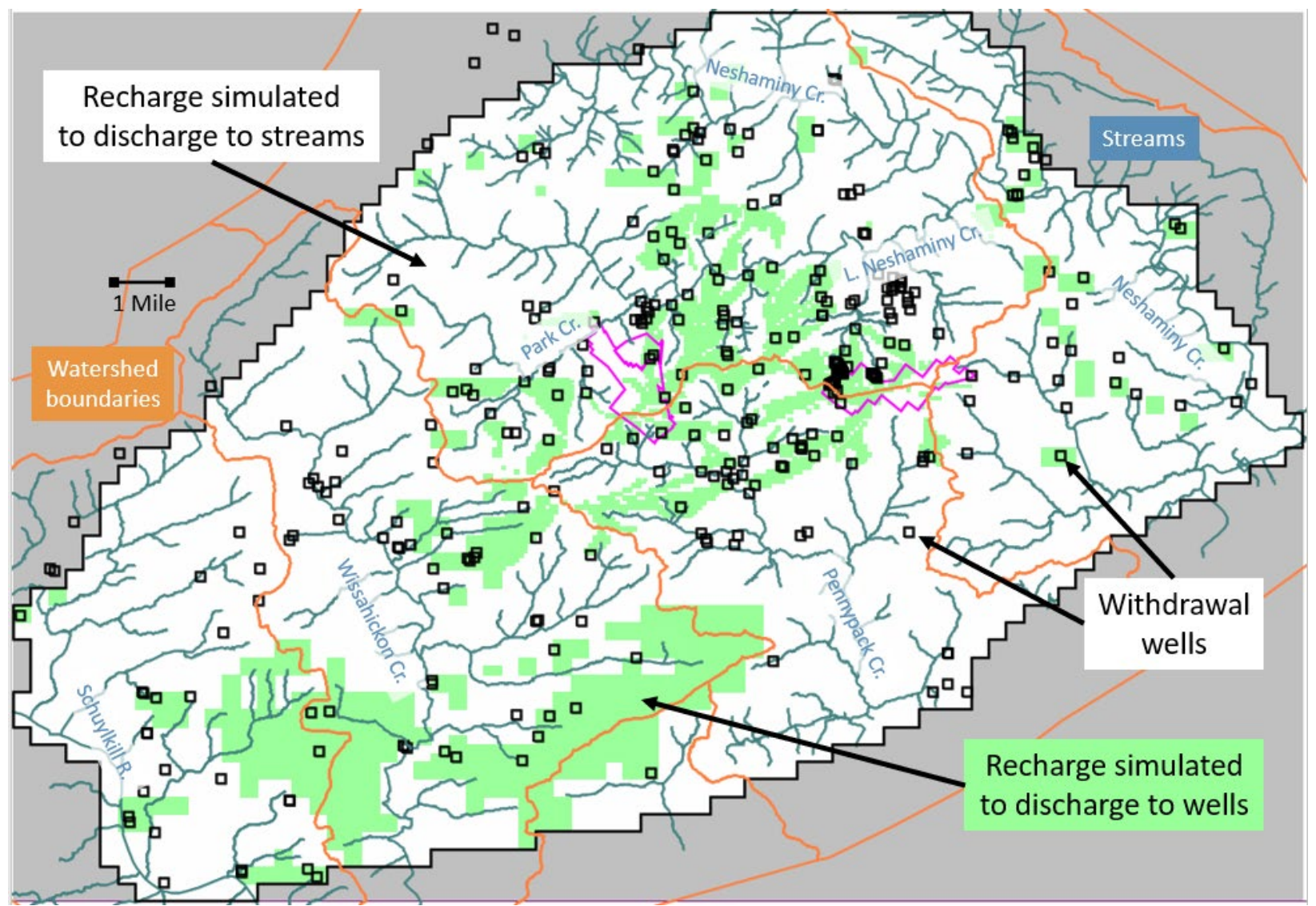

Figure 3.12. ModelMuse screenshot of simulated areas that contribute recharge to discharging wells (green) and streams (white) for 2013 conditions. 


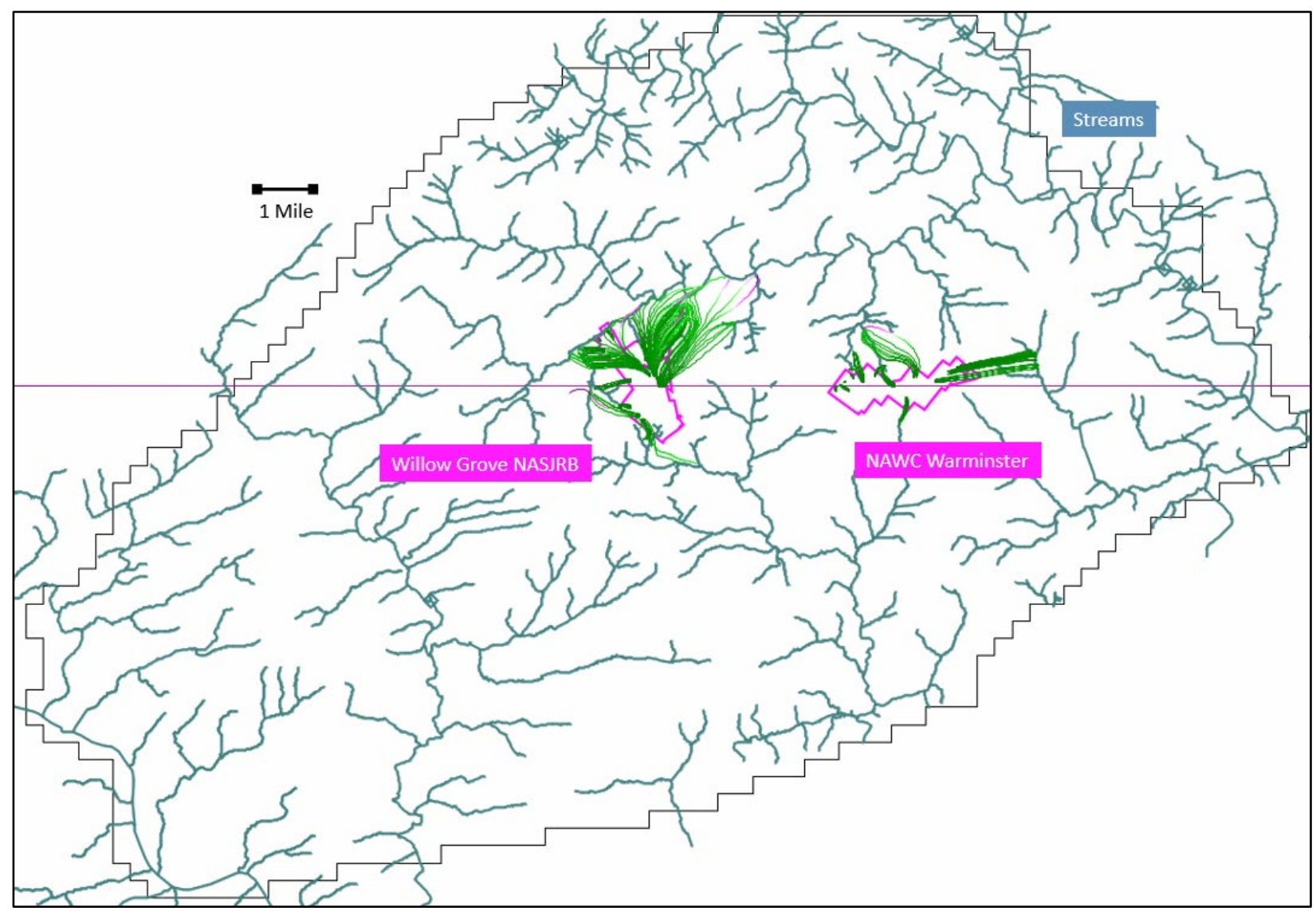

Figure 3.13. ModelMuse screenshot of simulated regional groundwater-flow paths from potential per- and polyfluoroalkyl substances (PFAS) contamination sources for 2013 conditions. Colors along paths range from green for relatively short travel times to magenta for relatively long travel times. 


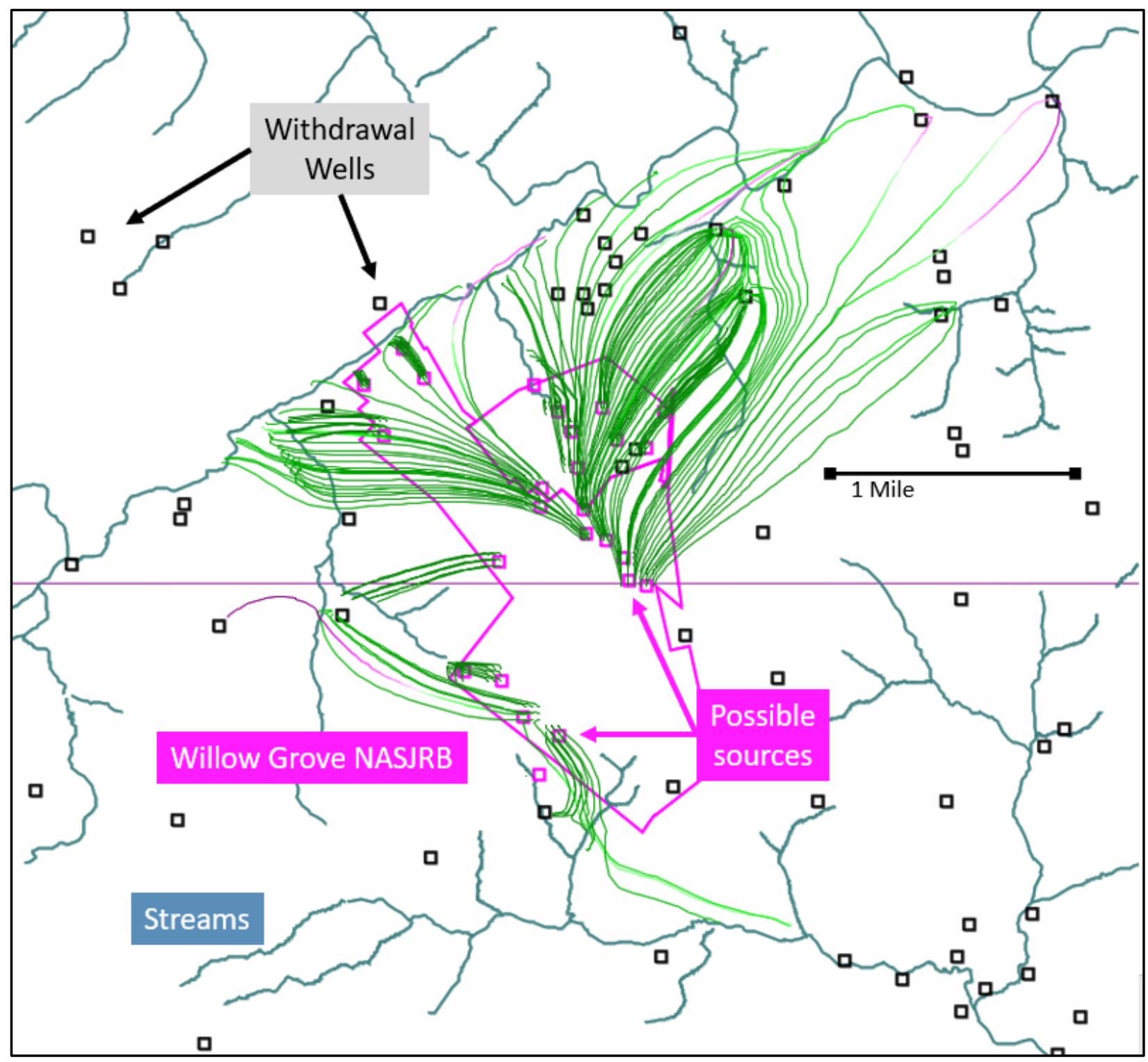

Figure 3.14. Detail of ModelMuse screenshot of simulated regional groundwater-flow paths for 2013 conditions near Willow Grove, with withdrawal wells in black. Pink squares represent areas of possible perand polyfluoroalkyl substances (PFAS) contamination in groundwater. Colors along paths range from green for relatively short travel times to magenta for relatively long travel times. 


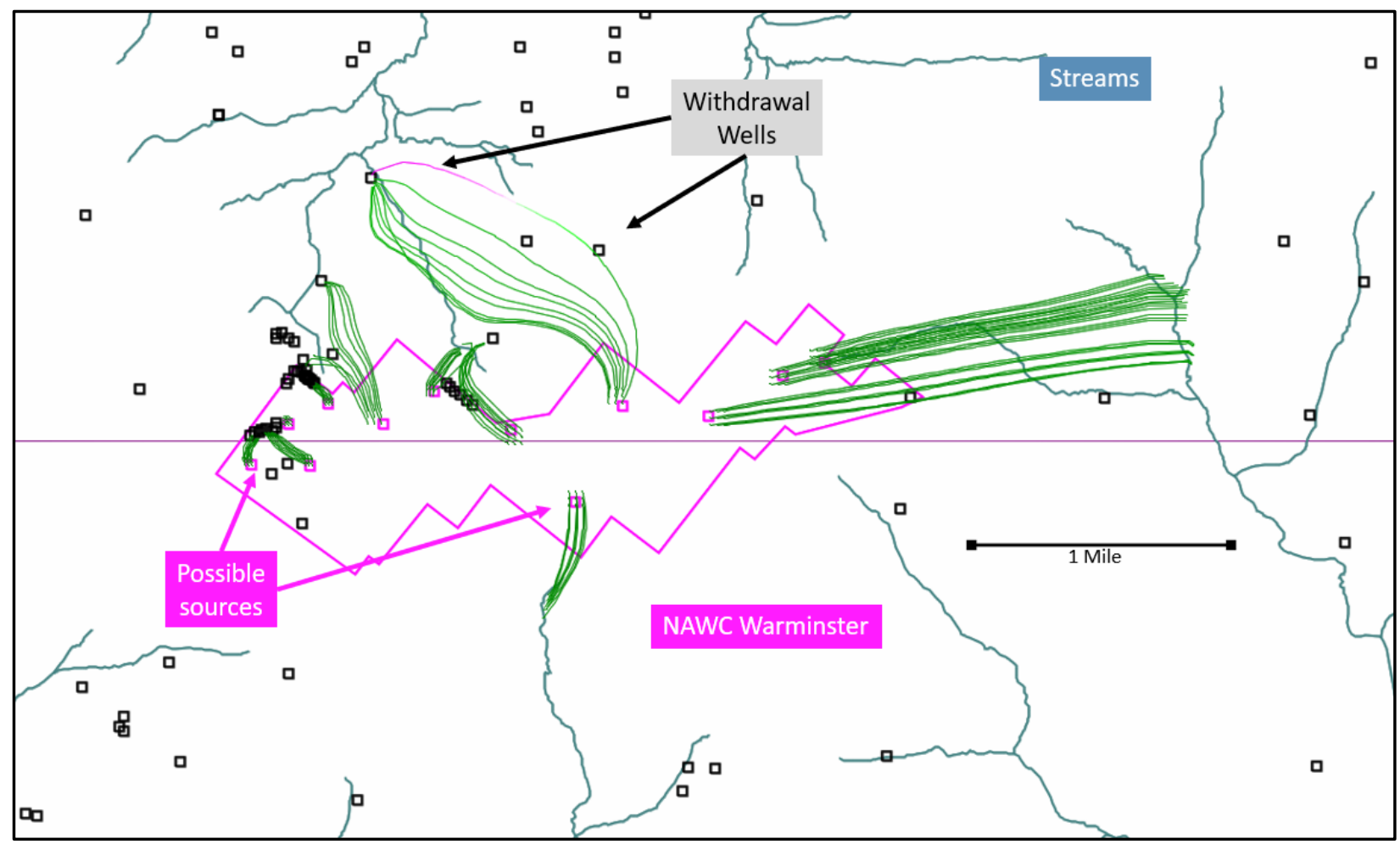

Figure 3.15. Detail of ModelMuse screenshot of simulated regional groundwater-flow paths for 2013 conditions near Warminster, with withdrawal wells in black. Pink squares represent areas of possible perand polyfluoroalkyl substances (PFAS) contamination in groundwater. Colors along paths range from green for relatively short travel times to magenta for relatively long travel times. 


\section{Conditions}

Simulated water levels for the calibrated model in layer 1 for 2016 conditions are shown in figure 3.16 and recharge simulated to be discharged to wells and streams is shown in figure 3.17. Willow Grove base production wells and some public supply wells in the area were operating at lower rates than in 2010. Recharge from precipitation was the lowest during this period and in 2017. Regional groundwater-flow paths for 2016 conditions are shown in figures $3.18-3.20$.

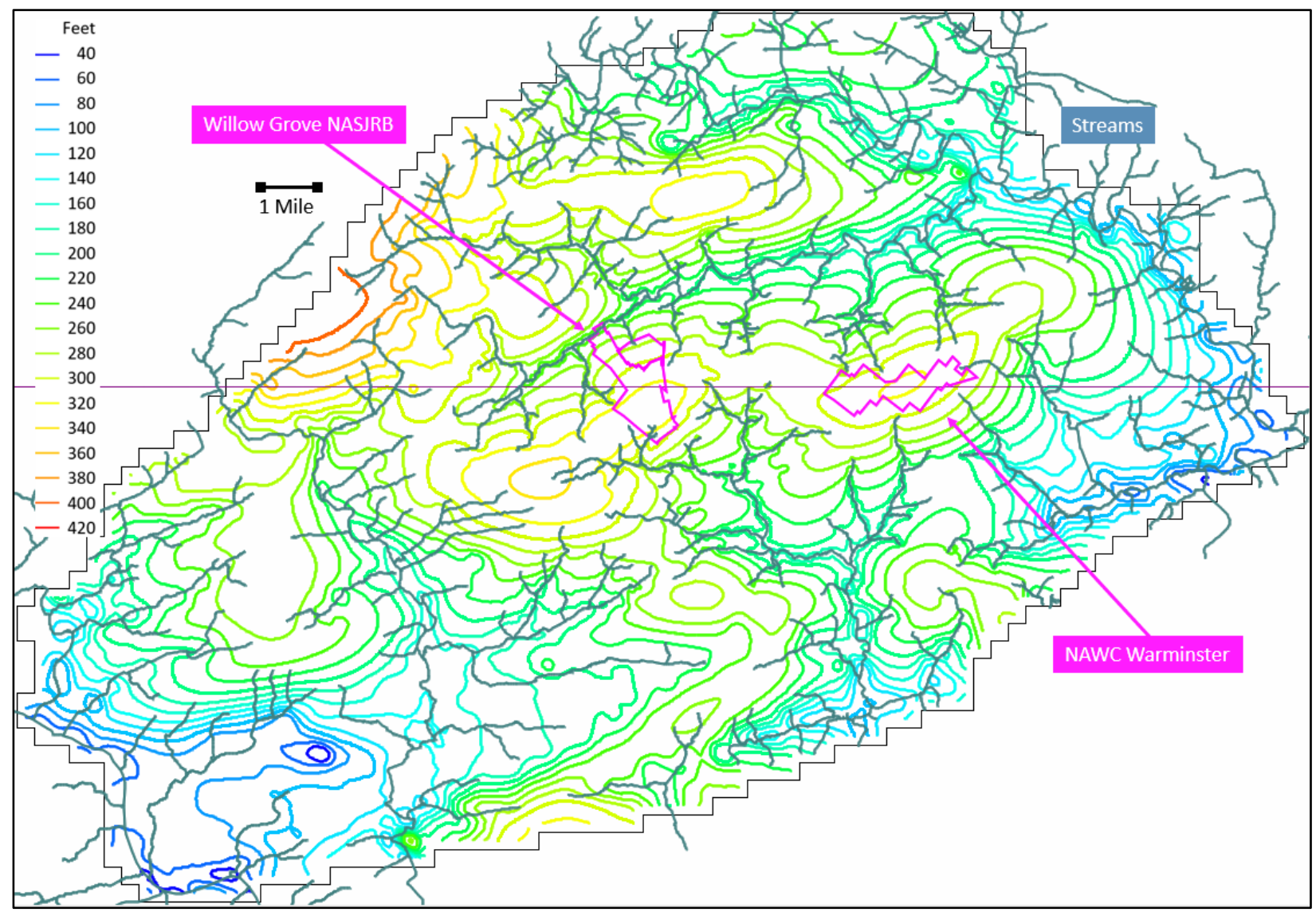

Figure 3.16. ModelMuse screenshot of simulated potentiometric surface in model layer 1 for 2016 conditions. Model streams are shown in blue gray. The contour interval is 20 feet. 


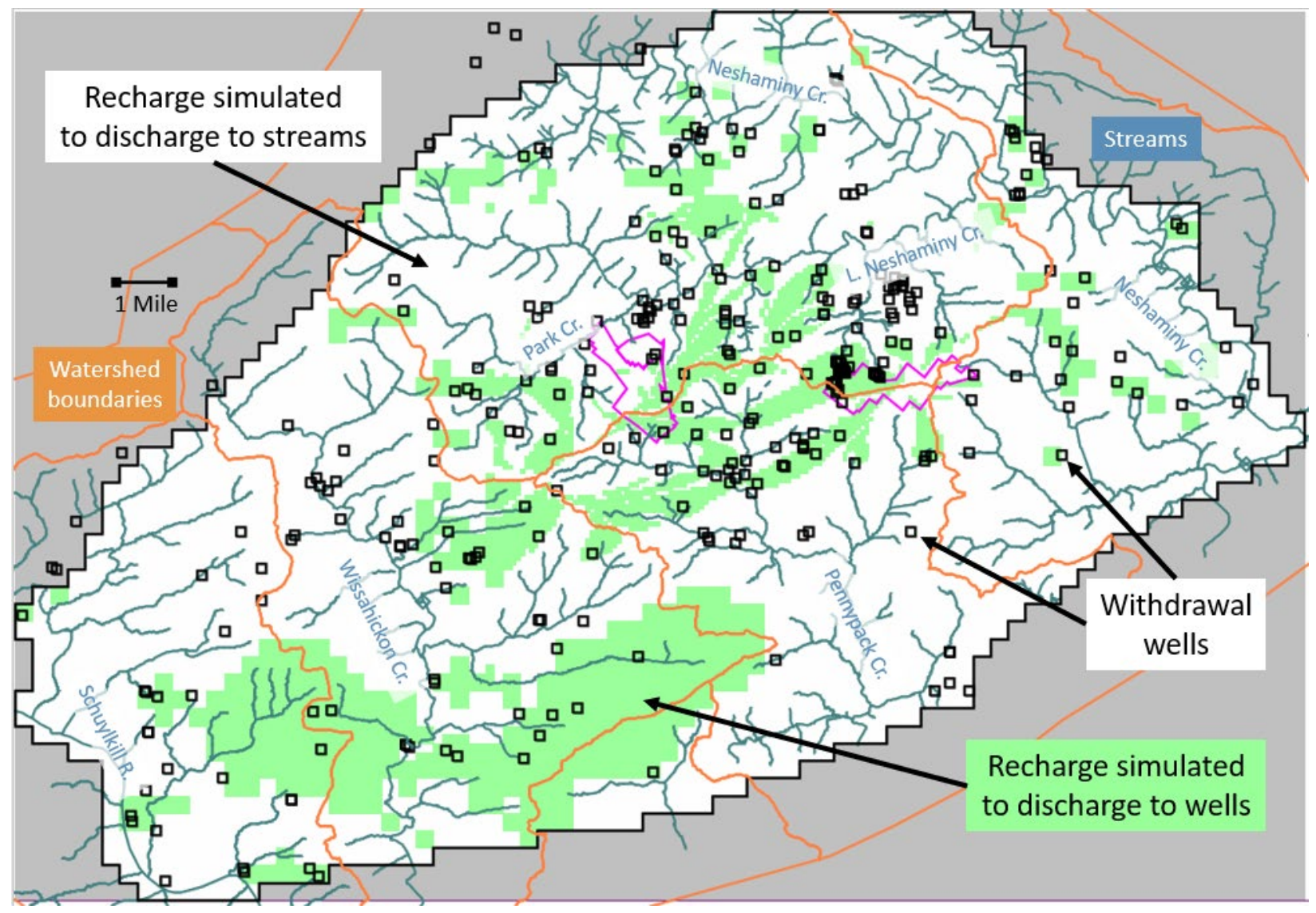

Figure 3.17. ModelMuse screenshot of simulated areas that contribute recharge to discharging wells (green) and streams (white) for 2016 conditions. 


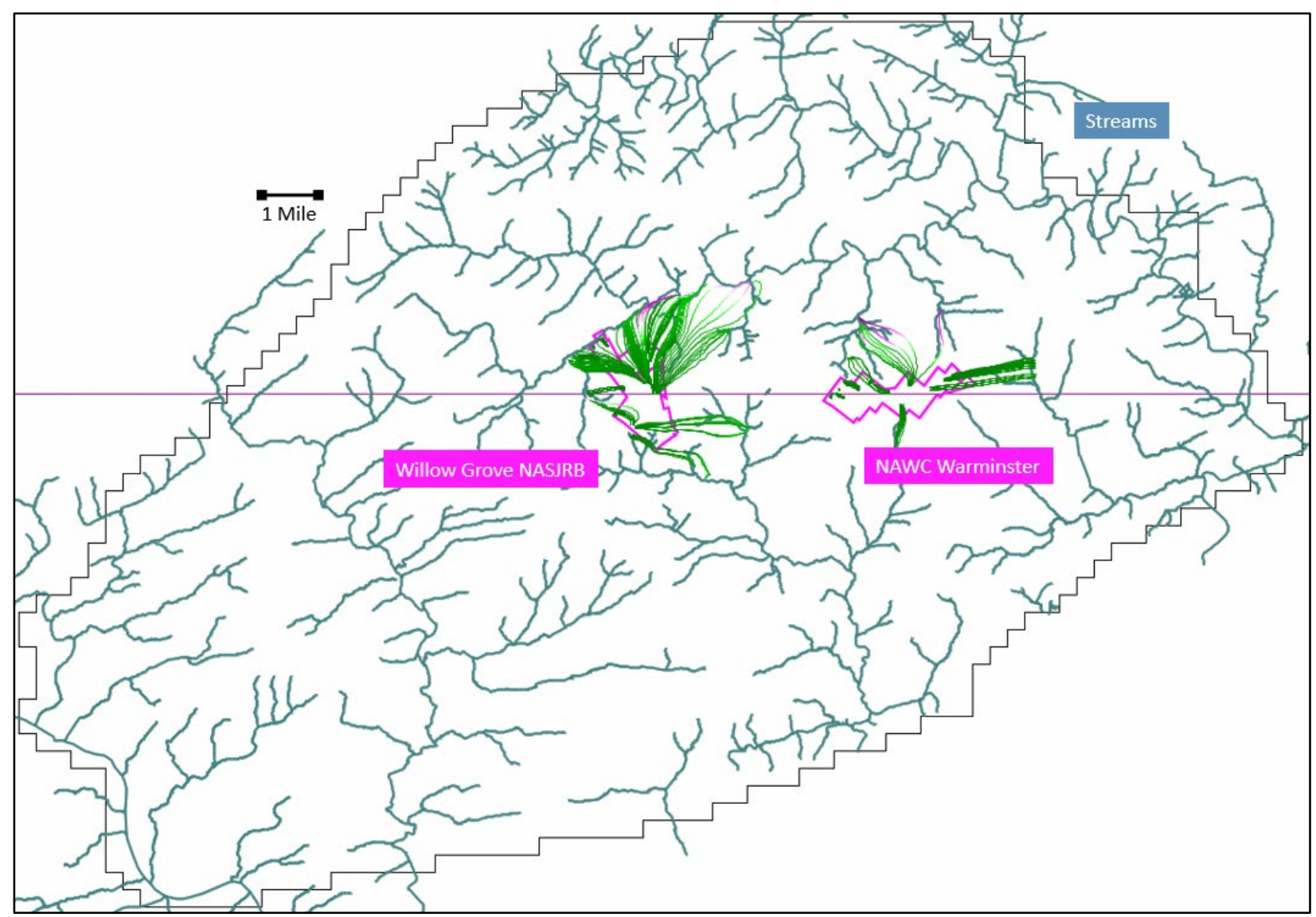

Figure 3.18. ModelMuse screenshot of simulated regional groundwater-flow paths from potential per- and polyfluoroalkyl substances (PFAS) contamination sources for 2016 conditions. Model streams are shown in blue gray. Colors along paths range from green for relatively short travel times to magenta for relatively long travel times. 


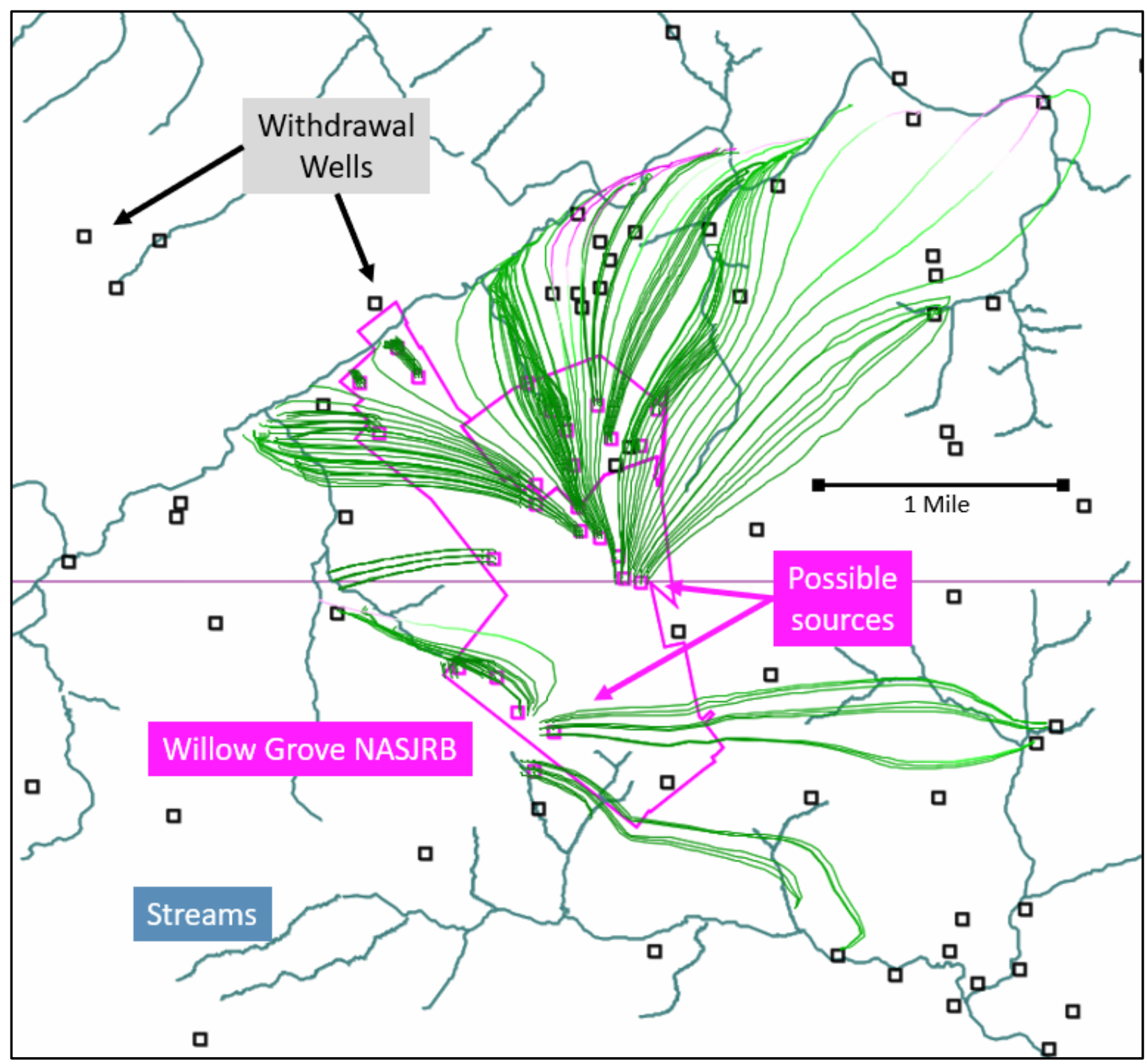

Figure 3.19. Detail of ModelMuse screenshot of simulated regional groundwater-flow paths for 2016 conditions near Willow Grove, with withdrawal wells in black. Pink squares represent areas of possible perand polyfluoroalkyl substances (PFAS) contamination in groundwater. Colors along paths range from green for relatively short travel times to magenta for relatively long travel times. 


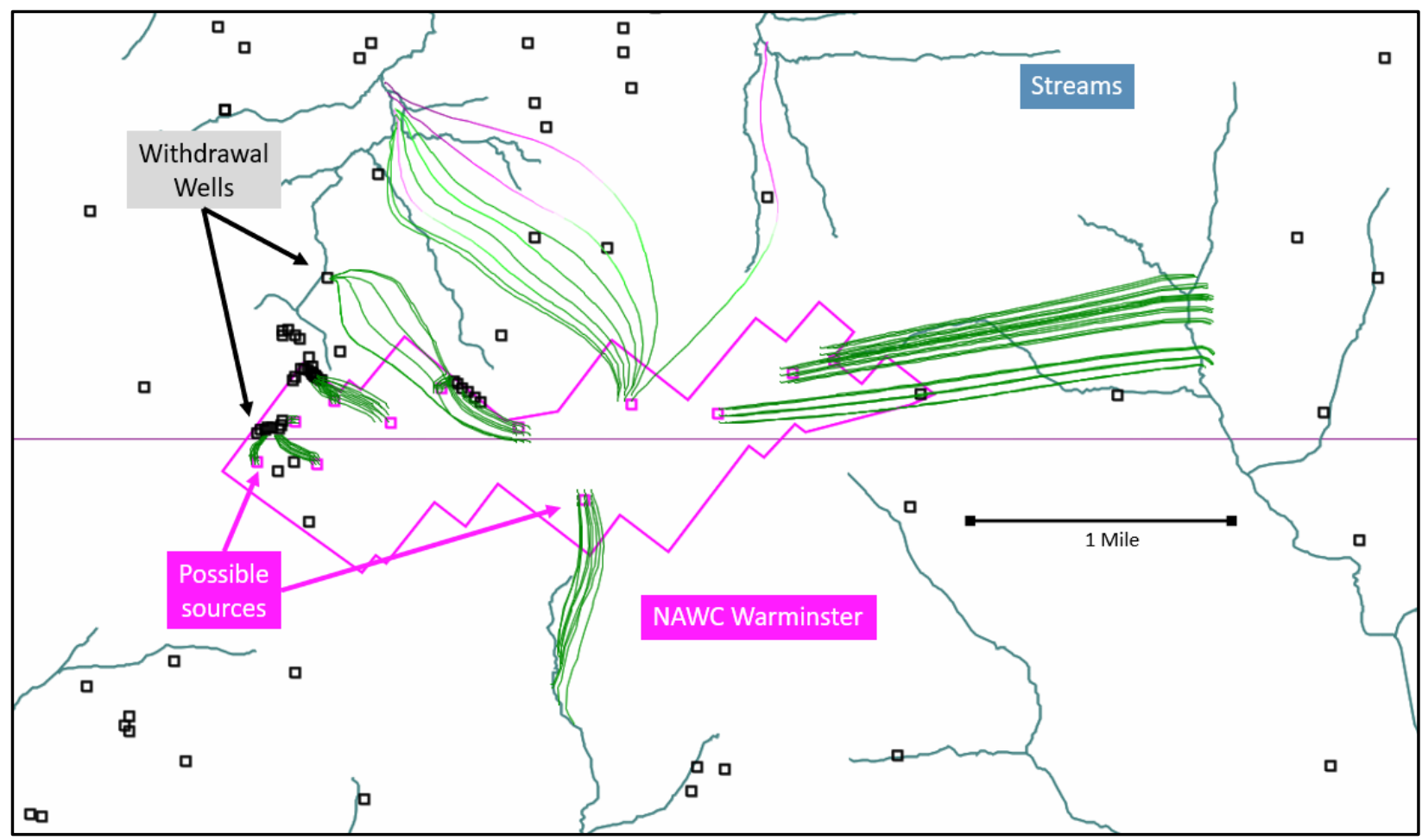

Figure 3.20. Detail of ModelMuse screenshot of simulated regional groundwater-flow paths for 2016 conditions near Warminster, with withdrawal wells in black. Pink squares represent areas of possible perand polyfluoroalkyl substances (PFAS) contamination in groundwater. Colors along paths range from green for relatively short travel times to magenta for relatively long travel times. 


\section{Conditions}

Simulated water levels for the calibrated model in layer 1 for 2017 conditions are shown in figure 3.21 and recharge simulated to be discharged to wells and streams is shown in figure 3.22. This time period had the least groundwater withdrawals and the lowest recharge rate, which was equal to that in 2016. This time period was not used for model calibration. Regional groundwater-flow paths for 2017 conditions are shown in figures 3.23-3.25.

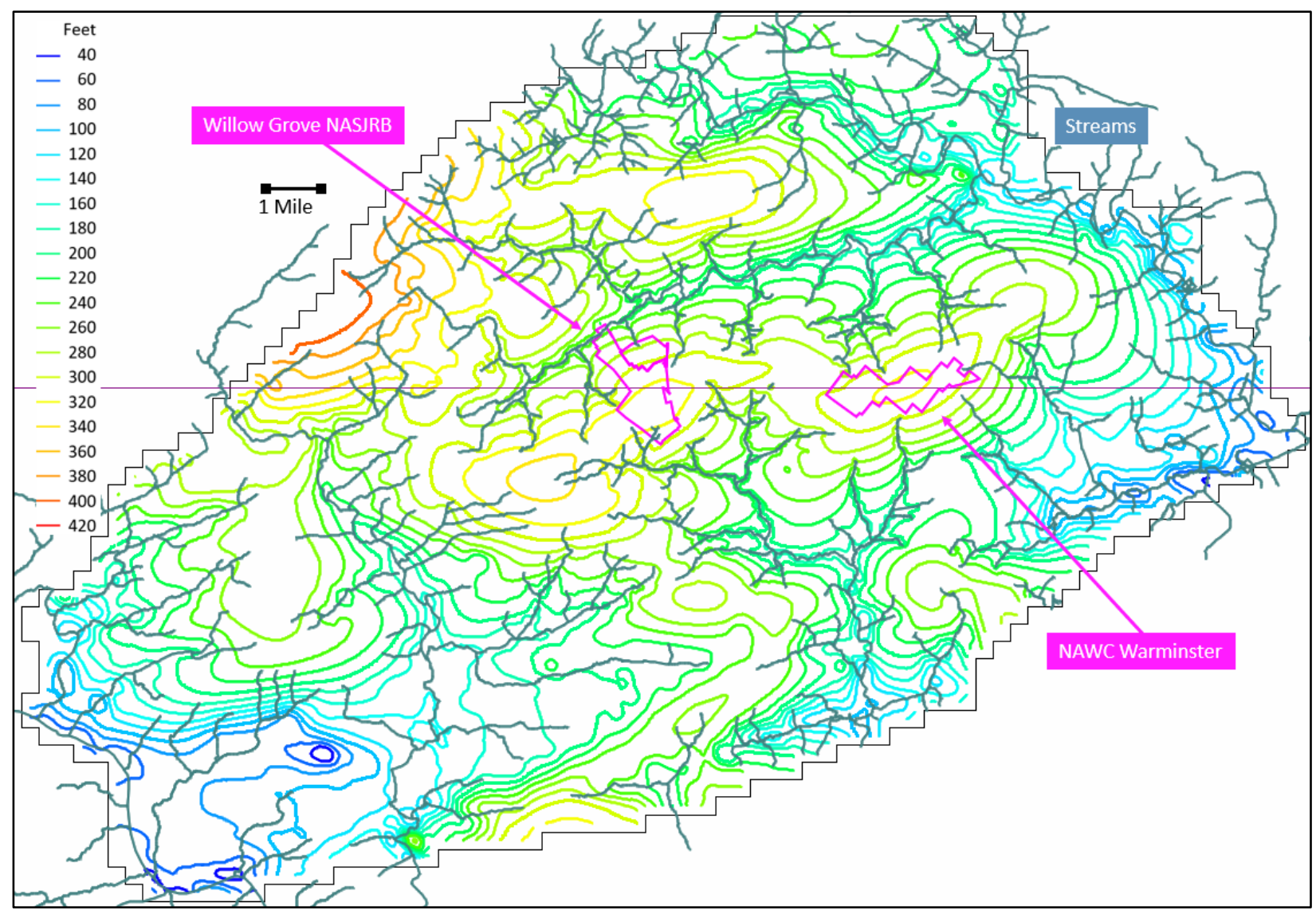

Figure 3.21. ModelMuse screenshot of simulated potentiometric surface in model layer 1 for 2017 conditions. Model streams are shown in blue gray. The contour interval is 20 feet. 


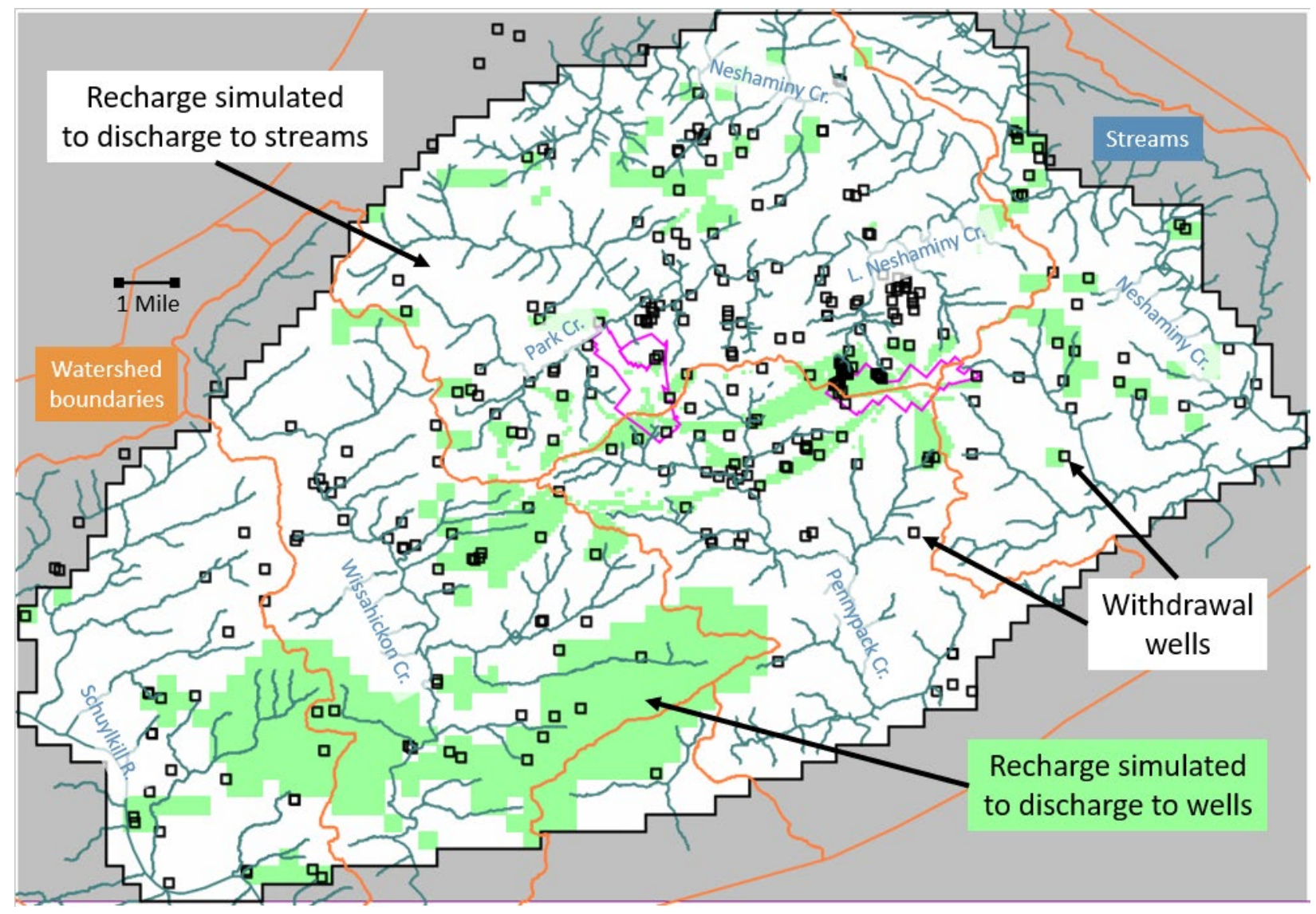

Figure 3.22. ModelMuse screenshot of simulated areas that contribute recharge to discharging wells (green) and streams (white) for 2017 conditions. 


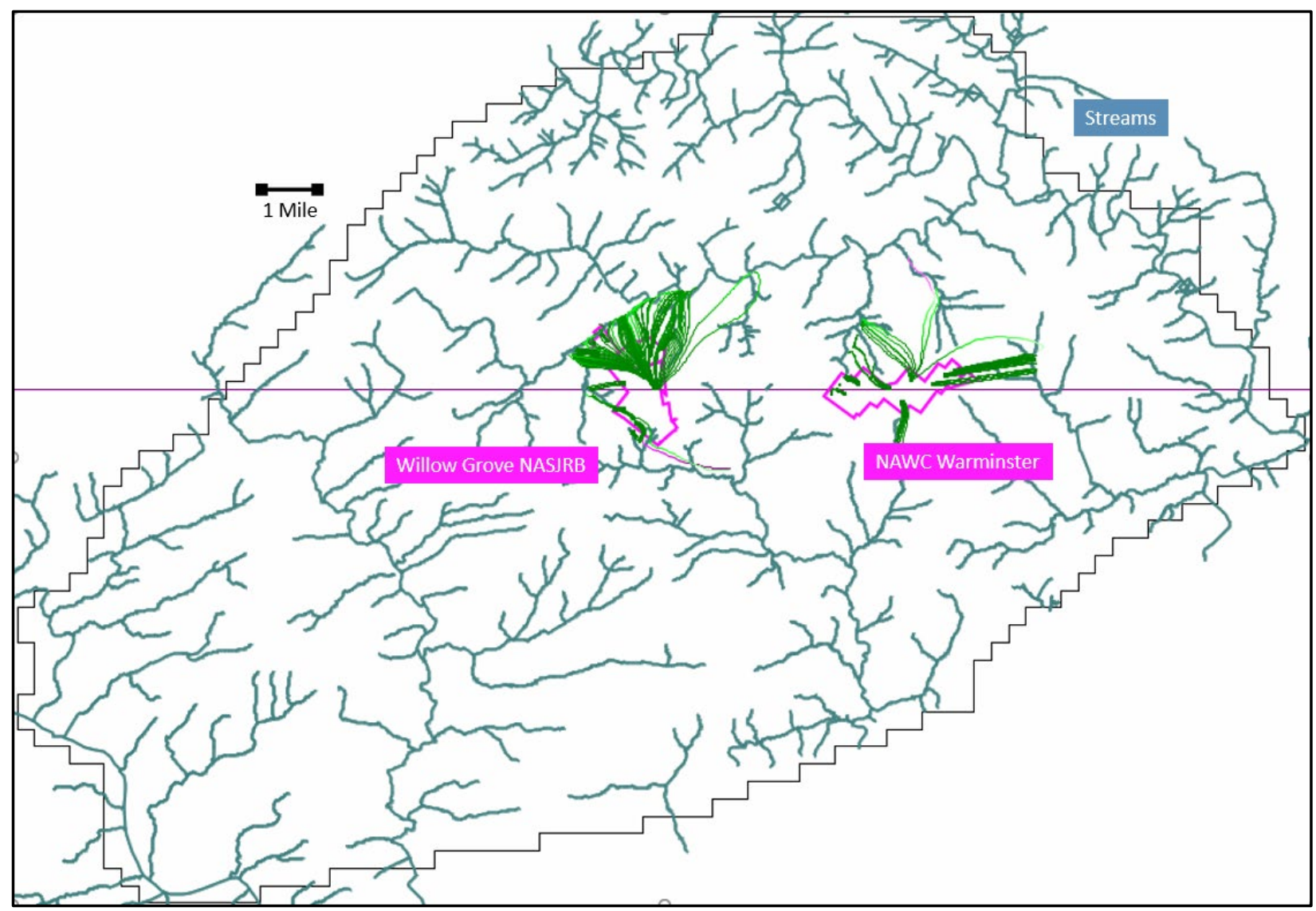

Figure 3.23. ModelMuse screenshot of simulated regional groundwater-flow paths from potential per- and polyfluoroalkyl substances (PFAS) contamination sources for 2017 conditions. Model streams are shown in blue gray. Colors along paths range from green for relatively short travel times to magenta for relatively long travel times. 


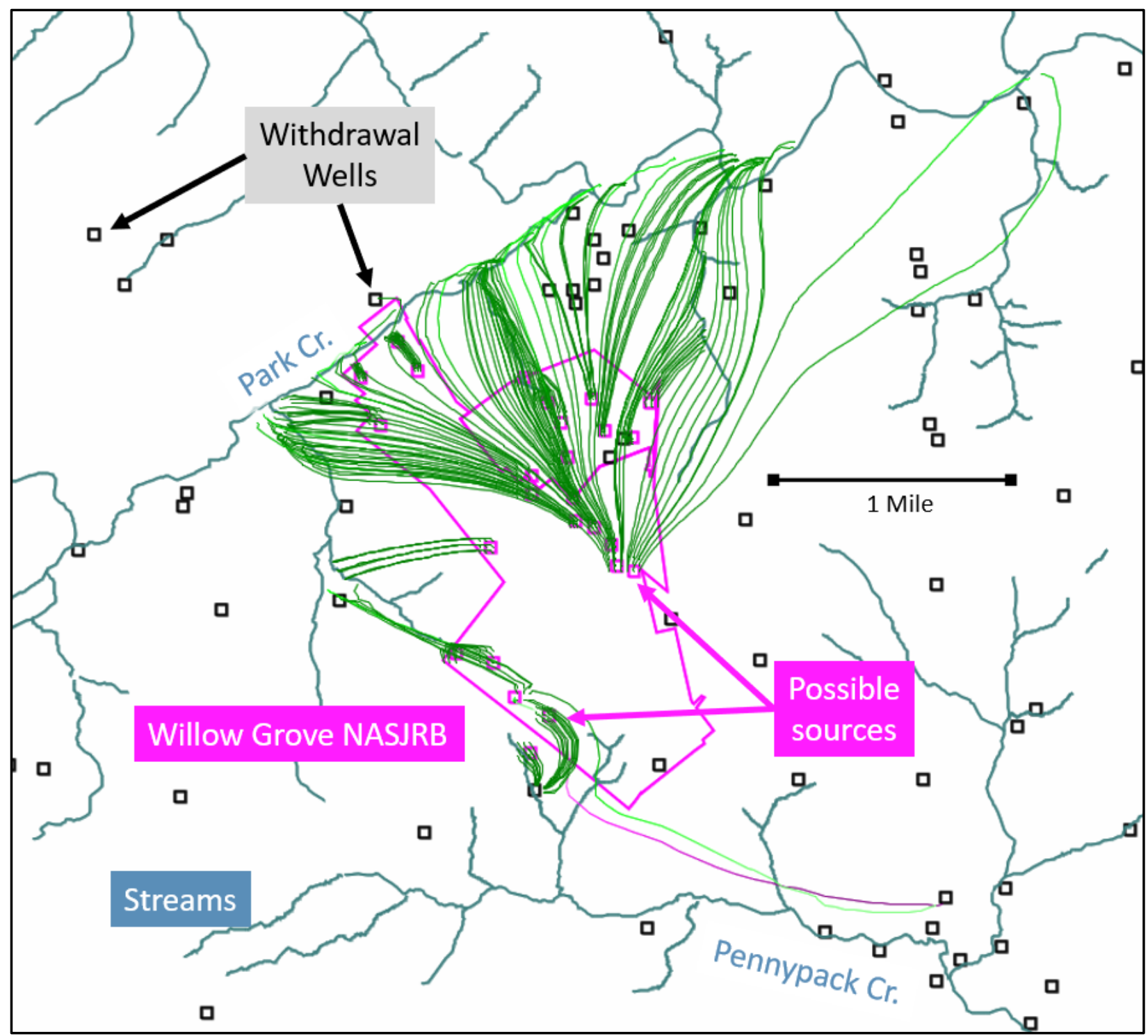

Figure 3.24. Detail of ModelMuse screenshot of simulated regional groundwater-flow paths for 2017 conditions near Willow Grove, with withdrawal wells in black. Pink squares represent areas of possible perand polyfluoroalkyl substances (PFAS) contamination in groundwater. Colors along paths range from green for relatively short travel times to magenta for relatively long travel times. 


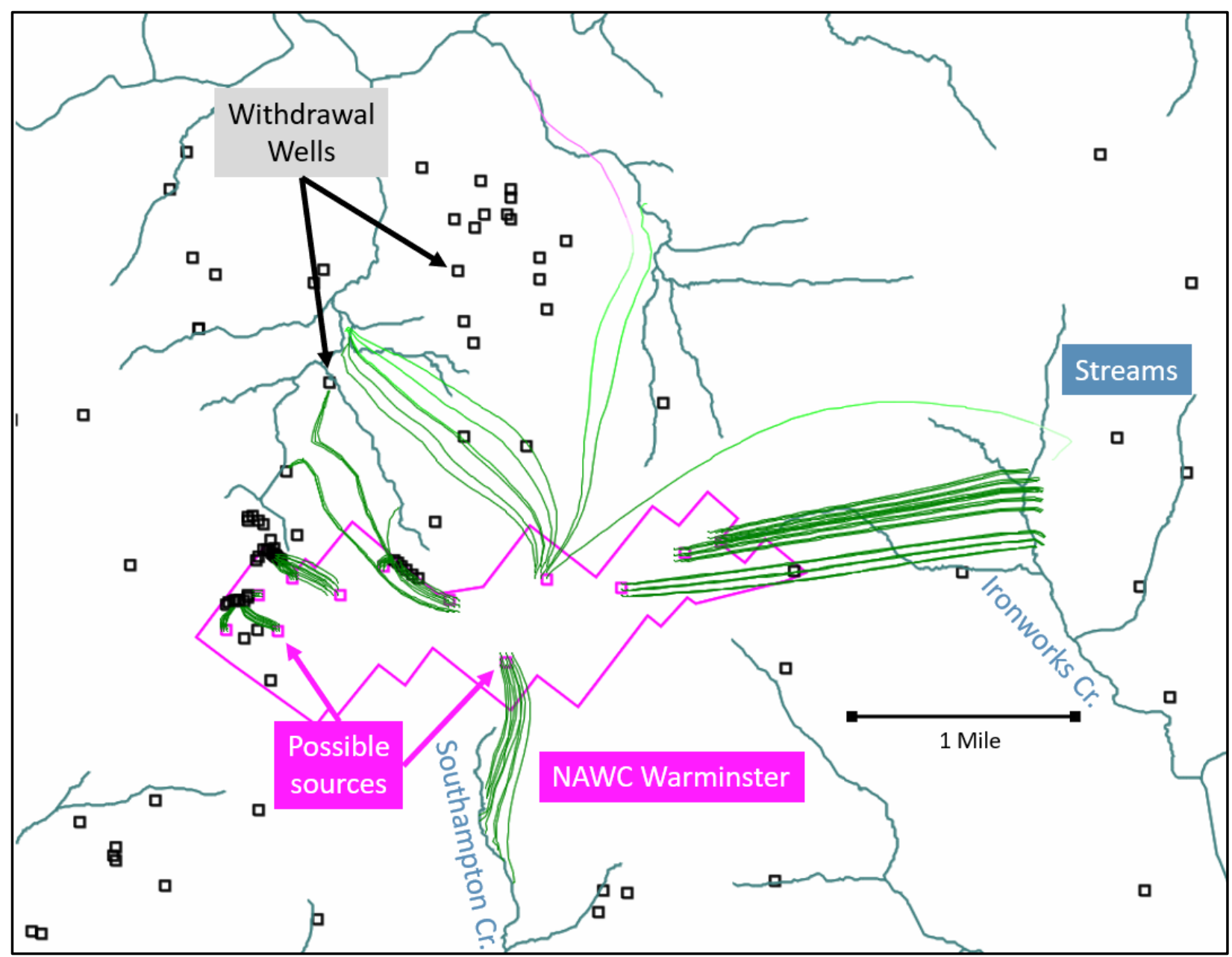

Figure 3.25. Detail of ModelMuse screenshot of simulated regional groundwater-flow paths for 2017 conditions near Warminster, with withdrawal wells in black. Pink squares represent areas of possible perand polyfluoroalkyl substances (PFAS) contamination in groundwater. Colors along paths range from green for relatively short travel times to magenta for relatively long travel times. 


\section{References}

Delaware River Basin Commission, 2019, Southeastern Pennsylvania ground water protected area (GWPA) GIS data sets: Delaware River Basin Commission web page, accessed November 1, 2019, at https://www.nj.gov/drbc/programs/project/pr/gwpa-data.html.

Goode, D.J., and Senior, L.A., 2020, MODFLOW 6 and MODPATH 7 model data sets used to evaluate groundwater flow in the vicinity of Horsham and Warminster, Bucks and Montgomery Counties, Pennsylvania-Preliminary simulations for conditions in 1999, 2010, 2013, 2016, and 2017: U.S. Geological Survey data release, https://doi.org/10.5066/P9K36P5S.

Pollock, D.W., 2016, User guide for MODPATH version 7-A particle-tracking model for MODFLOW: U.S. Geological Survey Open-File Report 2016-1086, 35 p., accessed July 9, 2018, at https://doi.org/10.3133/ofr20161086.

Pollock, D.W., 2017, MODPATH v7.2.01-A particle-tracking model for MODFLOW: U.S. Geological Survey software release, 15 December 2017, https://doi.org/10.5066/F70P0X5X. 
For additional information, contact:

Director, Pennsylvania Water Science Center

U.S. Geological Survey

215 Limekiln Road

New Cumberland, PA 17070-2424

Or visit our website at:

https://www.usgs.gov/centers/pa-water

ISSN 2331-1258 (online)

https://doi.org/10.3133/ofr20191137 